NATURA SOMOGYIENSIS 4.

\title{
MAGYARORSZÁGON ÉLŐ RAGADOZÓ EMLŐSÖK TÁPLÁLKOZÁS-ÖKOLÓGIÁJA
}

Feeding ecology of mammal predators

living in Hungary

LANSZKI JÓZSEF 


\section{Natura Somogyiensis 4.}

(A sorozat röviditett neve: Nat. Somogy. 4.)

\section{A kötetet lektorálta: Heltai Miklós és Körmendi Sándor}

1. Somogy megye fauna katalógusa, szerkesztette: ÁBRAHÁM L. (2001).

2. KASZA FERENC - MARIÁN MiKLós.: A Baláta-láp és gerinces állatvilága, különös tekintettel a madarakra (2001)

3. Miscellanea-Vegyes Tanulmányok, szerkesztette: ÁBRAHÁM L. (2002)

4. LANSZKI JÓZSEF: Magyarországon élő radadozó emlősök táplálkozás-ökológiája (2002)

5. A Látrányi puszta természetvédelmi terület élővilága (előkészületben)

Jelen kötetünk kiadását a National Geographic Channel magyarországi irodája, a Nemzeti Kulturális Örökség Minisztérium, a Kaposvári Egyetem, a Lábod RT. és Fonó Községi Önkormányzat Képviselő Testület támogatása tette lehetővé.

\section{NATIONAL GEOGRAPHIC CHANNEL}

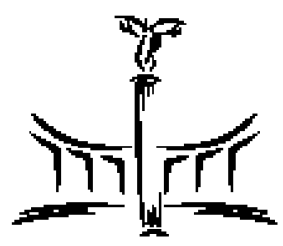

Szerkesztette:

Dr. ÁBraHÁm LEVENTE

A szerkesztố segédmunkatársai:

Horváth Péter, Kovács györgy, Zsoldos VIRÁG

Minden jog fenntartva. A mű egyetlen részlete sem használható fel, nem sokszorosítható és nem tárolható adathordozó rendszerben a kiadó írásos engedélye nélkül !

ISSN-1587-1908(Print)

ISSN 2062-9990 (Online)

ISB N 963-7212-35-3

DOI:10.24394/NatSom.2002.4.2

Kiadja a Somogy Megyei Múzeumok Igazgatósága Felelős kiadó: DR. WINKLER FERENC megyei múzeumigazgató Nyomdai munkák: Pethő \& TÁRsA NyomDAIPARI BT. Kaposvár 


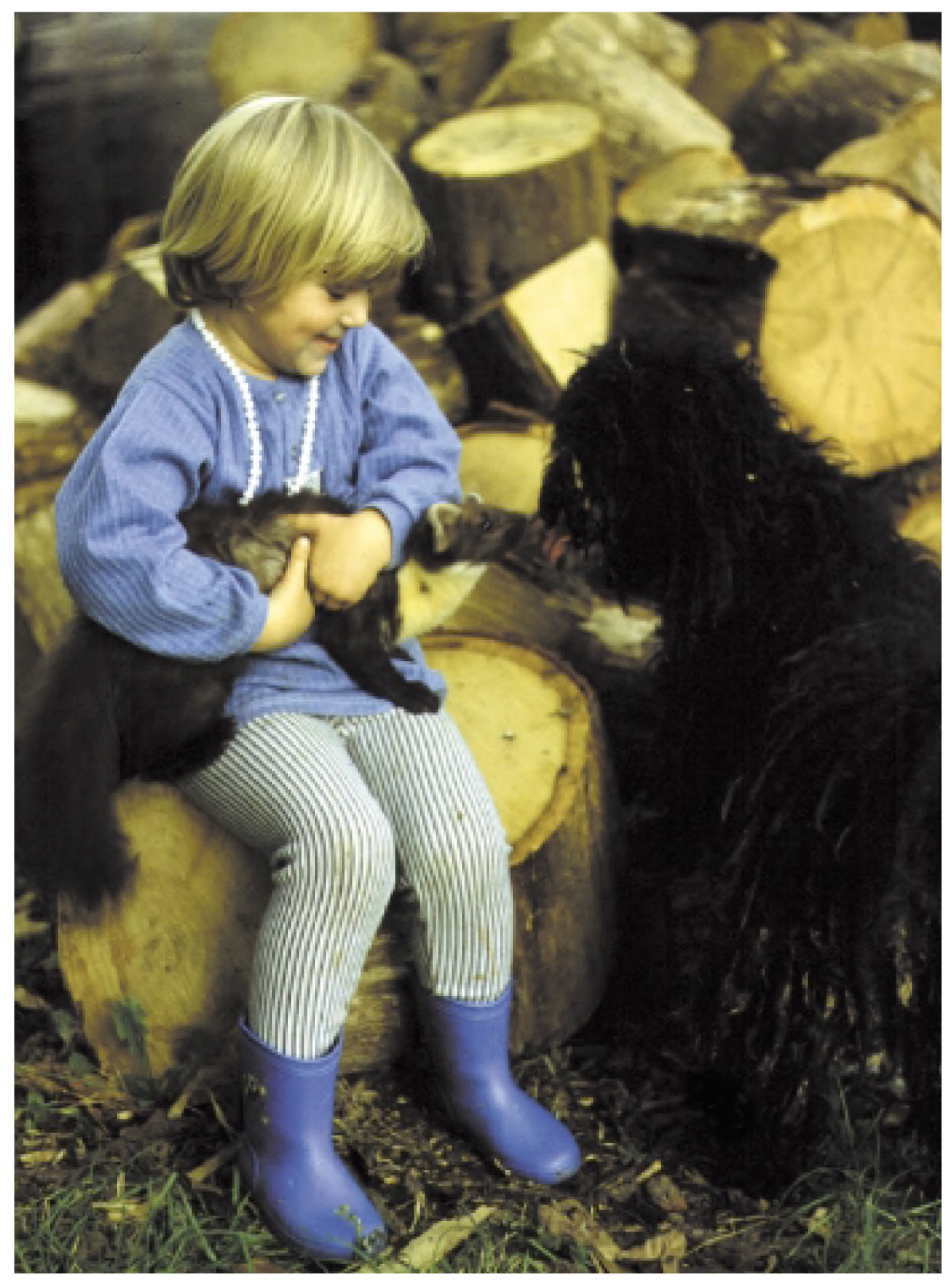

Zsófi lányomnak 


\section{Tartalom - Contents}

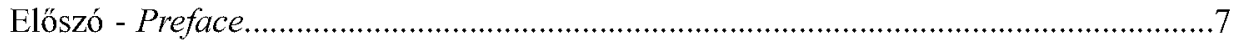

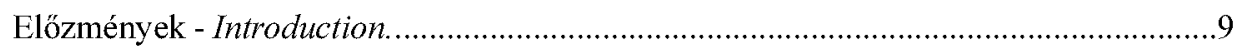

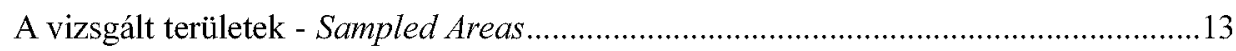

Mintagyújtés és feldolgozás - Collection and processing of samples.............................22

A táplálék-források felmérésének módszerei - Survey of food resourches.......................30

Az alkalmazott számítások és statisztikai módszerek- Applied statistical methods.........32

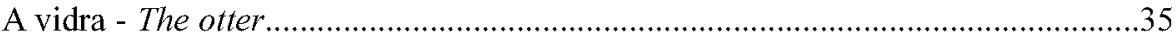

A vidra tápláléka és halpreferenciája halastavakon - Diet and fish

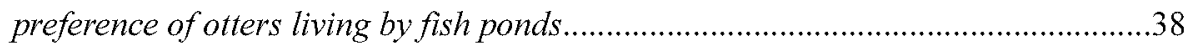

A vidra tápláléka különbözö típusú Dráva-menti élóhelyeken

Diet of otters living on different habitats along the Drava River ............................46

A vidra tápláléka biomassza számítás alapján - Diet of otters by

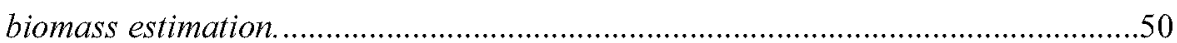

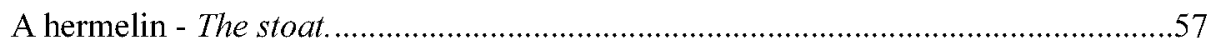

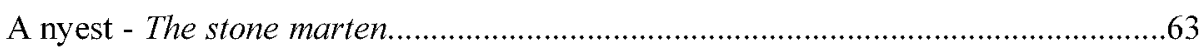

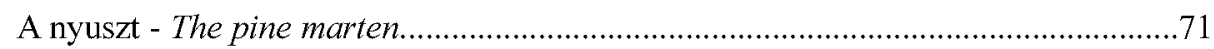

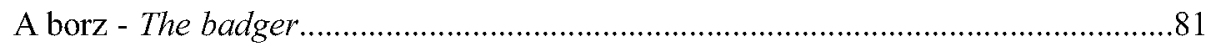

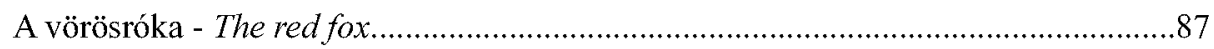

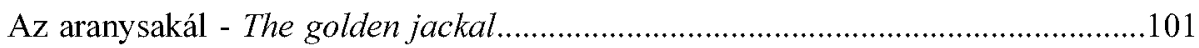

Fajok közötti táplálkozási kapcsolatok - Interspecific trophic relationships............111

Vidra populációk összehasonlító vizsgálata - Comparative analysis

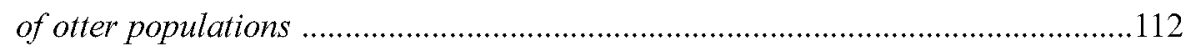

Ragadozók interspecifikus kapcsolatai - Comparative analysis

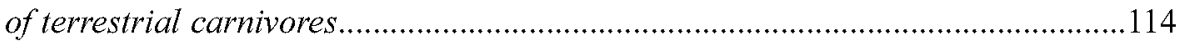

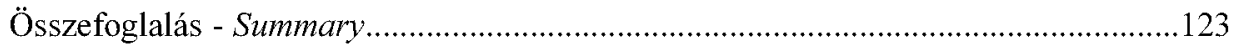

Zárógondolatok és köszönetnyilvánítás - Closing thoughts and acknowledgements....127

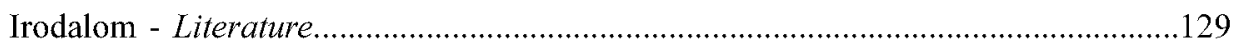

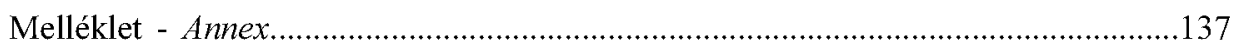

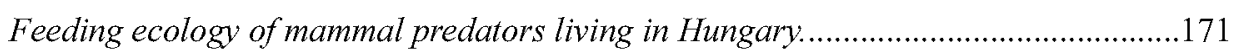

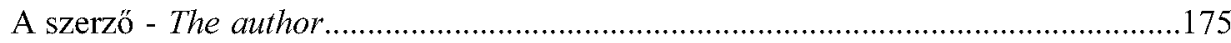




\section{Előszó}

A Kárpát-medence hajdan igen gazdag állatvilága szórványosan ugyan, de sok területen a mai napig fennmaradhatott. Ezt példázza Somogy megye erdőkben, vizes élóhelyekben való gazdagsága. Megörzött természeti értékeink kincset érnek most, az ezredforduló táján és a jövőben egyaránt. Ezek sorába tartozik számos ragadozónk is. Rejtőzködö életmódjuk, nehéz megfigyelhetőségük is hozzájárult a velük kapcsolatos hiedelmek terjedéséhez. Súlyosbítja mindenkori helyzetüket, hogy táplálékuk egy része azok közül az apró- és nagyvad fajok, esetenként háziállatok közül kerül ki, melyekre az ember is igényt tart. Emiatt a ragadozókat sokáig tüzzel-vassal irtották, mígnem a legtöbb faj állománya erőteljesen megcsappant, vagy a kipusztulás szélére sodródott. Más fajok viszont éppen az ember környezet-átalakító tevékenységével összefüggésben terjedhettek, sőt egyesek a falvakban, városokban "lakótársainkká" váltak.

Az elmúlt néhány évtizedben a ragadozók megítélése - az élővilág összefüggéseit megismerni akaró embereknek köszönhetően - világszerte lényegesen megváltozott. Ma egyre inkább a ritka fajok védelmének és a gyakoribbak bölcs hasznosításának nézete terjed.

A kötetet végiglapozó Olvasó egy tudományos igénnyel megírt, de ezzel együtt közérthető, hiánypótló tanulmányt tart a kezében. A hazai ragadozók táplálkozás-ökológiája témakörben ugyanis - kevés kivételtől eltekintve - eddig alig végeztek vizsgálatokat, hasonló összefoglaló jellegú munka pedig nem készült. Szerző, egy évtizedes terepi kutatómunkájának eredményeit gyűjtötte össze benne, de saját tapasztalatain túl, felhasználta a széleskörű nemzetközi irodalmat is. Alaposan alátámasztott megállapításai esetenként ma még talán merésznek tủnnek, de meggyőződéssel vállalja, vállalhatja azokat. Azt, hogy jó úton jár, a hazai és külföldi lektorált lapok szigorú szürőjén átjutott publikációi, szakmai elismertsége is mutatják. A könyvben szereplő eredmények nem csupán alapkutatás szinten állják meg helyüket, hanem a mindennapok természetvédelmi, halés vadgazdálkodási gyakorlatában is felhasználhatók.

Ajánlom ezt a kötetet mindazoknak, akik a ragadozók életmódjának, táplálkozási szokásainak megismerése iránt fogékonyak.

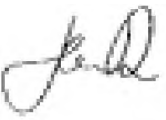

HORN PÉTER

akadémikus

a Kaposvári Egyetem Rektora

ISSN 1587-1908 (Print); ISSN 2062-9990 (Online) 
"Vannak szavak, melyeknek megbélyegzó jellegét szinte kiirthatatlamul magunkba vesszïk, s amikor kimondjuk, szinte látjuk a ragadozót, amint könyökig vájkál a vérben, fészkeket dúl, fiókákat fojtogat és általában úgy élö hússal él, és általában azt eszik nyersen, amit az elvetemült - ember. Ilyen szó a ragadozó!..."

(részlet Fekete István: Rózsakunyhó c. múvéből)

\section{Előzmények}

Az utóbbi években növekvő hazai és nemzetközi érdeklődés tapasztalható a ragadozó emlösök életmódjának minél alaposabb megismerése iránt. Valószínúleg ennek is köszönhetően számos, emlősállatokról szóló, szép küllemű ismeretterjesztő kiadványhoz juthatunk hozzá a hazai könyvesboltokban. A ragadozókkal foglalkozó oldalakon röviden megtalálható a fajok leírása, elterjedése és életmódja. Hazai szerzőktől, nagyobb terjedelemben mindössze néhány könyvben olvashatunk róluk (pl. VÁsÁRHELYI 1958, SZEDERJEI 1961, FARAGó 2002). A ragadozó és zsákmánya közötti kapcsolatok szerteágazó, bonyolult kérdéskörével foglalkozó irodalmat pedig SZÉKY (1983, 1986) tekintette át. Mégis úgy tűnik, hogy a nagyszámú külföldi vizsgálat mellett, a hazai körülmények között végzett terepi munkák háttérben maradtak. Ezt támasztják alá a honi természetvédelmi értékelési rendszerben, a kutatottság alapján kapott pontszámok is (BÁLDI et al. 1995). Eszerint az egyes fajok 0-tól 45-ig terjedő pontszámot kaphatnak, 45 pont a kutatottság teljes hiányát jelzi. Ebben a besorolásban a vörösróka 15 , a borz 28 , a nyest és a vidra 30 , a nyuszt és a hermelin 35 pontot kapott, az aranysakál pedig még a listán sem szerepel. Összehasonlításként néhány faj pontszáma: mezeinyúl, őz, gímszarvas: 3, hiúz: 40 pont (BÁLDI et al. 1995). A kutatások korábban mindössze a vadgazdálkodási szempontból jelentős vörösrókára terjedtek ki. ERDEI (1977) a 70-es, majd FARKAS (1983) a 80-as években végzett részletes táplálkozás-ökológiai vizsgálatokat. A vörösróka vadászatával és ökológiájával foglalkozó irodalmat pedig HeLTAY (1989) foglalta össze. Hosszú szünet után, kutatáson alapuló, táplálkozás-ökológia témájú publikációk csak az utóbbi években készülttek.

Ragadozó emlós fajokban Magyarország az egyik leggazdagabb európai ország, 15 faj jelenléte bizonyítható határainkon belül (HELTAI 2002). Vannak közöttük állandóan jelen levố, közönséges fajok, továbbá korábban kipusztult, de napjainkban spontán visszatelepülő, valamint betelepülő (invazív) fajok is. Ebben a könyvben hét endemikus ragadozónk táplálkozás-ökológiai kutatásának eredményei találhatók meg. Valamilyen szempontból mindegyik fontos szerepet tölt be a táplálékhálózatokban. Lényegesen befolyásolják az életközösségek múködését és szerkezetét, vadgazdálkodási, tógazdasági és/vagy természetvédelmi szempontból is jelentősek.

A nemzetközileg legrészletesebben tanulmányozott, fokozottan védett vidra ( Lutra lutra Linnaeus, 1758) táplálék-összetételének és halpreferenciájának ismerete tudományos és gazdasági szempontból egyaránt fontos. A hazai állomány fontos része az Európainak, nálunk ugyanis ez a faj még viszonylag gyakori. Állományának monitorozása (a változások és okainak nyomon követése), életmódjának, ökológiai igényeinek pontosabb megismerése a faj fennmaradása, élőhelyeinek kezelése és védelme szempontjából lényeges. A vidra vizes élőhelyekhez kötődik, ezeknek általában különösen nagy a kör- 
nyezeti sérülékenységük, biológiailag sokszínúek és tájképi értékük is kiemelkedő. A területek jelentôs részén halgazdálkodás folyik, ahol a felmerülố konfliktusok nem kezelhetốk objektív ismeretek nélkül.

A védett hermelin (Mustela erminea Linnaeus, 1758) táplálkozási kapcsolatai a vizsgált fajok közül nemzetközi viszonylatban a legkevésbé ismertek, a hazai populációk életmódjáról igen hiányosak az ismeretek.

Az idényben vadászható nyest (Martes foina Erxleben, 1777) a nagy kiterjedésü, öszszefüggő erdőségek kivételével gyakorlatilag mindenféle élőhelyen előfordulhat. A rókához hasonlóan urbanizálódásra képes faj. Eletmódját külföldön meglehetősen részletesen tanulmányozták.

A védett nyuszt (Martes martes Linnaeus, 1758) tipikus erdei ragadozó. Madárfogyasztása miatt státuszát vitatják, annak ellenére, hogy életmódját hazai élőhelyi feltételek mellett nem kutatták.

A védett fajok listáján a 2001-es évtől már nem szereplő, idényben vadászható borz (Meles meles Linnaeus, 1758), az utóbbi években elterjedőben van (SZEMETHY és HELTAI 1996, SzEMETHY et al. 1998, 2000). Annak ellenére, hogy táplálkozási szokásait nálunk korábban nem kutatták részletesen, mezőgazdasági és vadgazdálkodásban betöltött szerepe vitatott.

A vizsgált fajok között a vadászható vörösróka (Vulpes vulpes Linnaeus, 1758) hazai és nemzetközi viszonylatban is a legjobban ismert ragadozó. Vadgazdálkodási és közegészségügyi szempontból egyaránt jelentős. Napjainkban a rókaállomány gyorsan emelkedik, mely csak részben függ össze a veszettség elleni immunizálási tevékenységgel (HELTAI et al. 2000c, SzEMETHY et al. 1998). A róka gyakori előfordulása számos kérdést vet fel, például az apróvad gazdálkodás, az állatról emberre terjedő betegségek, a háziállatok predációja, vagy a ragadozó életközösség fajaira gyakorolt hatás (interspecifikus kompetíció) területén.

Az aranysakál (Canis aureus Linnaeus, 1758) Vörös Könyves fajunk (RAKONCZAY 1989), az elmúlt száz év alatti ritka előfordulása miatt kipusztultnak minősült és szinte feledésbe merült. Bár vadgazdálkodási szempontból jelentős predátor, a visszatelepült állományok életmódja Közép-Európában ismeretlen, a fajt csak Ázsiában, Afrikában és Dél-Európában, lényegesen eltérő környezeti feltételek mellett tanulmányozták. Az állományának monitorozása, a vadállományra gyakorolt hatásának vizsgálata kiemelt érdeklődésre tart számot.

A könyvben terjedelmi okok miatt eltekintettem a fajok részletes morfológiai, elterjedési, szaporodásbiológiai leírásától, ezek az ismeretek monográfiákban (LLOYD 1981, MAson és MaCDONALD 1986, GitTleman et al. 1989, KRUUK 1989, Buskirk et al. 1994, KRUUK 1995, NeAL és CHEESEMAN 1996, JEDRZEJEWSKA és JEDRZEJEWSKI 1998, MiTCHELL-JONES et al. 1999, FARAGÓ 2002) és cikkekben általában megtalálhatók. A hazai ragadozó emlős fajok elterjedését és állományváltozását az elmúlt 15 évben végzett kérdóíves felmérések elemzése alapján HELTAI (2002) dolgozta fel. Részletes magyar nyelvű, tudományos igényű, több tudományterület ismereteit is magába foglaló áttekintő mủ azonban máig sem készült ragadozóinkról. Jelen kötetben a végzett vizsgálatok jellege miatt elsősorban csak egy szúk terület, a ragadozó és zsákmánya közötti kapcsolatok kis szeletének bemutatására szorítkozhattam. Az áttekintés érdekében a Magyarországon (is) előforduló ragadozó fajok életmódjának fóbb jellemzőit egy összefoglaló táblázat (1. melléklet) tartalmazza.

E kötetben az elmúlt tíz évben - 1991 és 2001 közötti időszakban - végzett táplálkozás-ökológiai kutatásaink eredményeit foglaltam össze. Az itt szerepló vizsgálatok a Dél-Dunántúlon, nagyrészt Somogy megyében zajlottak, de ezek mellett tömören a korábbi hazai, valamint a külföldi kutatásokat is bemutatom. Az eredmények többségét föként külföldi cikkekben, társszerzőkkel már közöltük, vagy jelenleg folyik megjelente- 
tésük, ám számos eddig még nem publikált adat is szerepel a könyvben. A fejezetek végén szögletes zárójelben megadtam a témában készült eredeti publikációkat is. Néhány további megjegyzés és magyarázat. Az összehasonlító vizsgálatok érdekében a korábbi adatok újbóli csoportosítását el kellett végezni. A korábbi kutatási metodika megválasztásával függ össze, hogy egyes esetekben a táplálék-összetételt csak százalékos relatív előfordulási gyakoriság szerint adtam meg, de legtöbbször e mellett a táplálékmaradványok súlya alapján végzett biomassza számítás eredménye is megtalálható. Az egyes fejezetek kialakításakor arra törekedtem, hogy az eredmények ismertetése közérthetô legyen és a szemléltető ábrák áttekintést adjanak a fajok táplálék-összetételéről. Ezért kerültek a részletes táblázatok mellékletbe, valamint ezért tekintettem el a statisztikai próbák eredményeinek részletezésétől is. Remélhetően a tanulmány alapját képező kutatási adatok újdonságot jelenthetnek a ragadozók iránt általánosságban érdeklődő Olvasónak, de érdeklődésre tarthatnak számot a más szakterületen dolgozó zoológusok számára is. A tízezernél több feldolgozott minta feltehetően statisztikailag is meggyőzónek bizonyul.

A tanulmány egyik fó célkitǔzése a különböző élöhelyek vidra populációinak évszakos táplálékának elemzése, valamint a haltáplálék-forrás és a vidra haltápláléka közötti összefüggés vizsgálata volt. A szárazföldi ragadozók kapcsán kitüzött célok: a menyétfélék családjába tartozó hermelin, nyest, nyuszt és borz, valamint a kutyafélék családjába tartozó vörösróka és aranysakál évszakonkénti táplálék-összetételének és táplálék választásának, továbbá a fajok közötti táplálkozási kapcsolatok vizsgálata volt. 


\section{A vizsgált területek}

A könyvben szereplő területek elhelyezkedését a Dél-Dunántúlon az 1. ábra mutatja be.

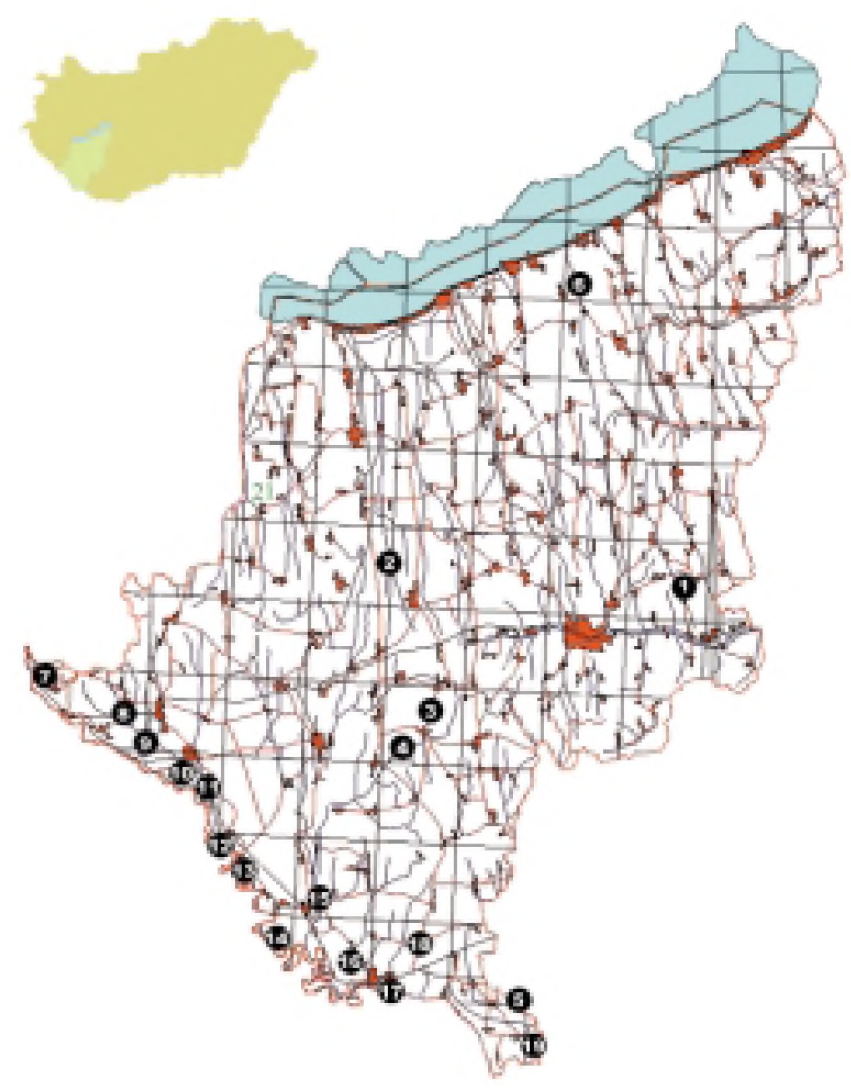

1. ábra: A vizsgált területek elhelyezkedése a Dél-Dunántúlon

1. Fonói halastó körzete; 2. Boronka-melléki Tájvédelmi Körzet; 3. Mike-Csököly körzete; 4. MikePetesmalom körzete; 5. Kétújfalu körzete; 6. Látrányi füves puszta TT.; 7. Örtilos (Szentmihály-hegy); 8. Gyékényes, Dombó-csatorna; 9. Lankóci-erdó; 10. Berzence, Dombó csatorna; 11. Somogyudvarhelyi kavicsbánya tavak; 12. Bélavár, holtág; 13. Vízvár, Dráva; 14. Babócsa, Erzsébet sziget; 15. Babócsa, Rinya; 16. Drávaszentes, Barcs-Komlósdi Rinya; 17. Barcs, Kis-bóki holtág; 18. Barcsi Borókás Tájegység, Középrigóci tavak; 19. Lakócsa, Korcsina csatorna 


\section{A Fonói halastó és körzete}

A Fonói halastó és körzete Külsô-Somogyban helyezkedik el. A tavat tápláló BatéMagyaratádi patak a Kapos folyó vízgyưjtőjéhez tartozik, mely a Sióba, majd a Dunába folyik. Erre a vidékre alapvetốen a szántóföldi növények termesztése jellemző. A közeli vízfolyásokon, 3-5 km-es távolságban mesterséges tavak, valamint mozaikszerủen 10 - 80 ha területű erdők találhatók. A „körzet" kifejezést a továbbiakban a területbejárások során érintett, mintagyújtésre kijelölt területre vonatkozóan használom.

1. táblázat: A Fonói halastó körzetének fỏbb élőhely típusai

Megjegyzések: I. időszak $=1 .+2$. vizsgálati évek (1991 decembertől 1993 novemberig),

II. időszak $=3 .+4$. vizsgálati évek (1993 decembertól 1995 novemberig),

III. időszak $=5 .+6$. vizsgálati évek (1995 decembertől 1997 novemberig) .

\begin{tabular}{|c|c|c|c|}
\hline \multirow{3}{*}{ Élõhely típus } & \multicolumn{3}{|c|}{ Idõszak } \\
\hline & I. & II. & III. \\
\hline & \multicolumn{3}{|c|}{ Százalékos megoszlás } \\
\hline Víz felül đt & 7,4 & 0,8 & 13,1 \\
\hline Sás és gyékény & 17,2 & 18,9 & 11,5 \\
\hline Rét és bokorfüzes & 7,4 & 6,6 & 7,4 \\
\hline Fás legelõ & 4,9 & 4,9 & 4,9 \\
\hline Vadföld & 2,4 & 0,0 & 1,6 \\
\hline Erdõ & 32,8 & 26,2 & 26,2 \\
\hline Szántó & 27,9 & 27,9 & 27,9 \\
\hline Gyomtársulások & 0,0 & 14,8 & 7,4 \\
\hline
\end{tabular}

A Fonói halastó és körzetében (rövidítése: FHTk) táplálkozás-ökológiai szempontból vizsgált hat évet három idószakra osztottam fel a gazdálkodásban bekövetkezett lényeges változások miatt (84. ábra a mellékletben). Az I. és a III. időszakban a föbb élőhely típusok eloszlása nem különbözött szignifikánsan egymástól (1. táblázat), azonban a II. időszak ezektôl lényegesen eltért $(\mathrm{P}<0,001)$. A vizsgálat első időszakában (rövidítése $\mathrm{FHTk}_{\mathrm{I}}$ ) a halastó felüllete $12 \mathrm{ha}$, a csatlakozó vizes élöhelyekkel együitt $\mathrm{kb}$. 30 ha volt. A második időszakban $\left(\mathrm{FHTk}_{\mathrm{II}}\right)$ a halastó vízzel való feltöltése és halasítása elmaradt, a vízhez közeli erdőrész egy részét letermelték, a vadföld-gazdálkodást befejezték. A tó medrének szárazra kerülésével, valamint a letermelt területrész és vadföldek magára hagyásával gyomtársulások váltak uralkodóvá. A halastó privatizációját követổn, a negyedik év végén a tó töltésének rekonstrukciója, a részleges mederkotrás és a part karbantartása megtörtént A vízfelület a harmadik időszakban ( HHTk $_{\text {III }}$ ) 17-18 ha volt. Az elsổ és harmadik időszakban halászati tevékenység zajlott polikultúrás népesítéssel, ponty dominanciával. A második idôszakban haltelepítés nem történt, ezért a kis méretü, gazdaságilag jelentéktelen halak népesítették be a patakot.

A terület növényzete a dél-dunántúli flóravidék külsô-somogyi flórajárásához tartozik. A tó nyugati partján, nagyobbrészt egészen a tó partvonaláig cseres-tölgyes erdó (Quercetum petraeae-cerris) húzódik. Az erdő kora kb. 65 év, kiterjedése kb. 70 ha, szántóval szabdalt. A tó északi oldalán kis kiterjedésű rét és bokorfüzes (Salicetum triandrae-purpurea), valamint magassásos (Caricetum acutiformis-ripariae) és nádas (Scirpo-Phragmitetum) teszi változatossá a növényzetet. A halastó keleti oldalán nagy kiterjedésű szántó, délen nyílt legelö, valamint fás legelő (Betula pendula, Robinia pseudo-acacia) húzódik. A halastótól délkeleti irányban található Fonó község gyümölcsös kertekkel. 


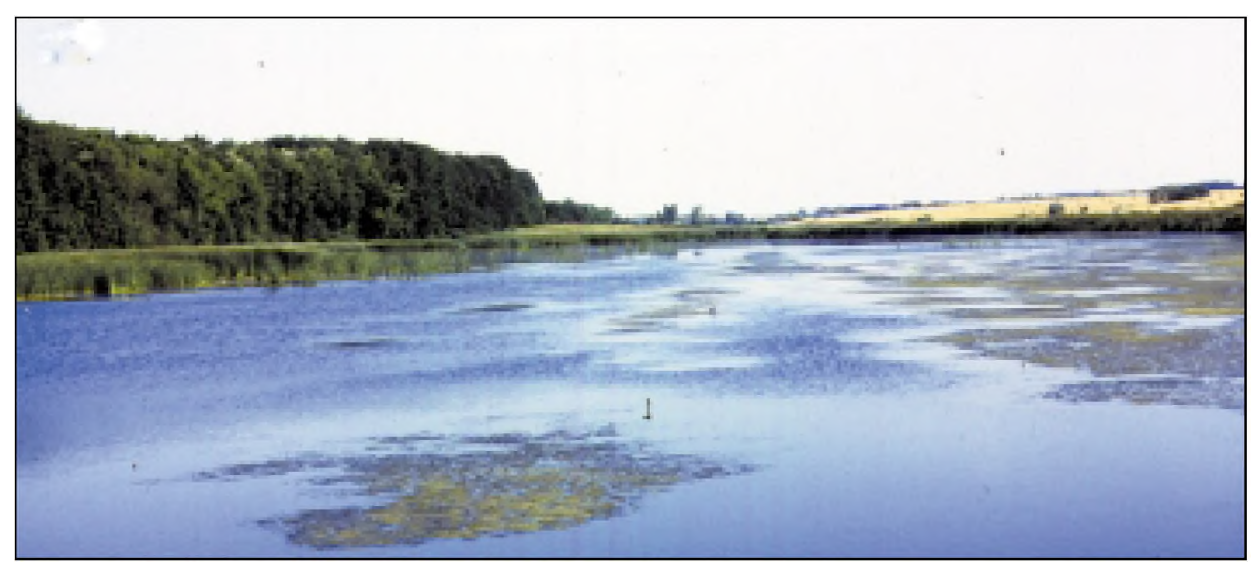

2. ábra: A fonói tó az első vizsgált időszakban

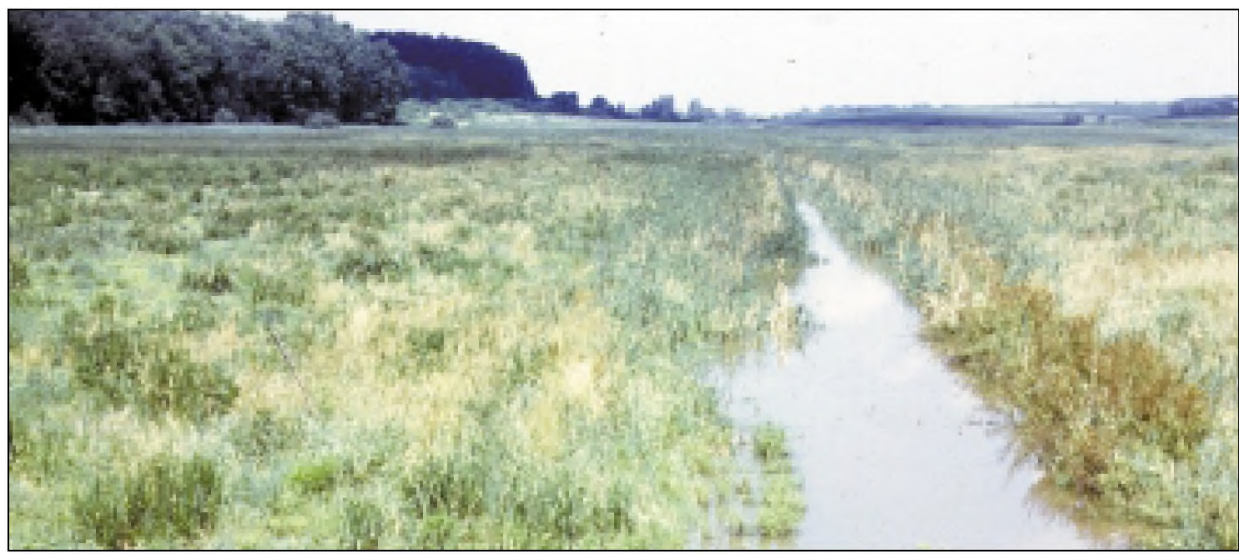

3. ábra: A fonói tó a második vizsgált időszakban

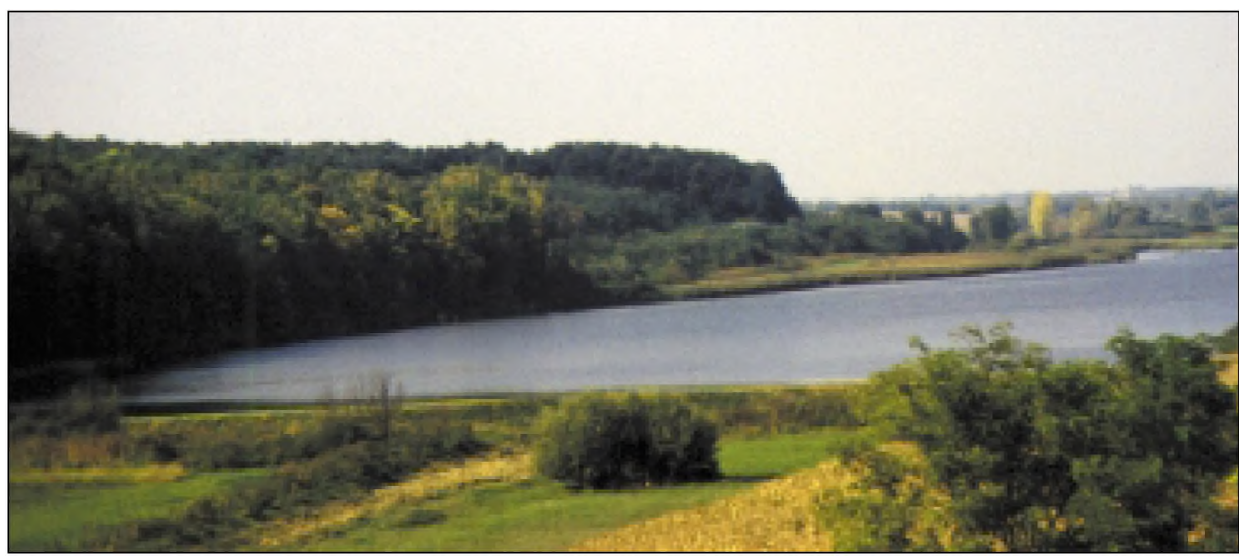

4. ábra: A fonói tó a harmadik vizsgált időszakban 


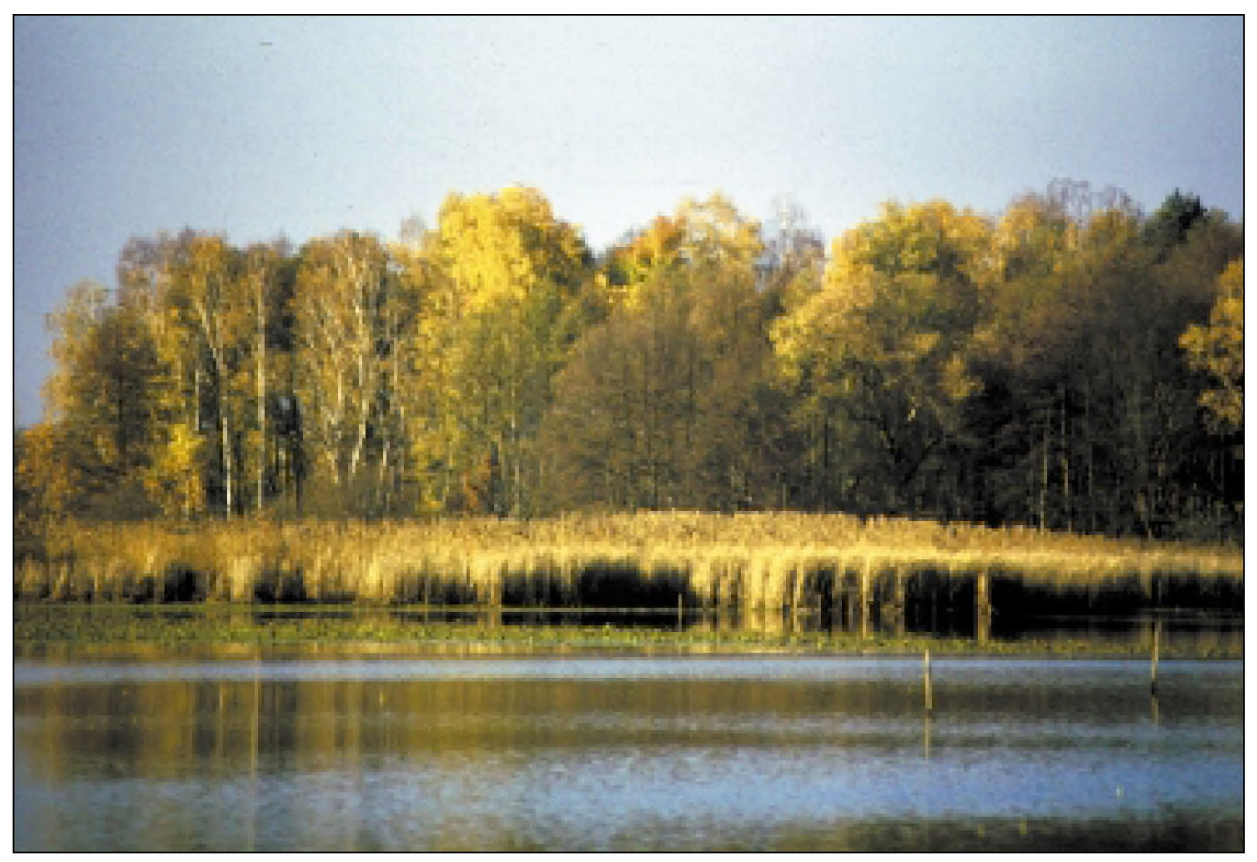

5. ábra: A Boronka-melléki Tájvédelmi Körzet tavi látképe

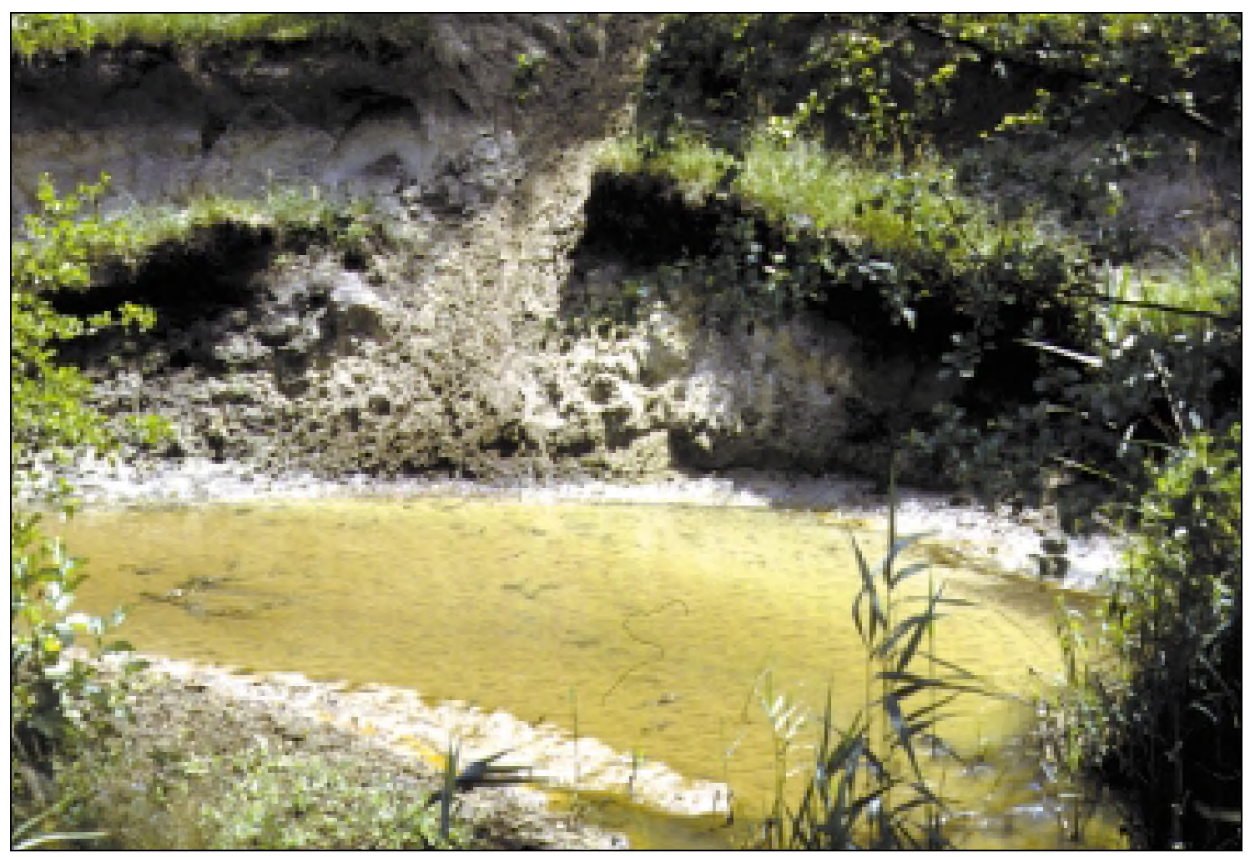

6. ábra: Petesmalom tórendszerének patakja 


\section{A Boronka-melléki Tájvédelmi Körzet}

A Belső-Somogyban található, 8000 ha kiterjedésű Boronka-melléki Tájvédelmi Körzet (rövidítése BmTK) patakjai a Balaton vízgyűjtőrendszeréhez tartoznak (85. ábra a mellékletben). A vizsgálatban szereplö Dávodi körzetben 6 völgyzárógátas halastó található, melyeket a XIX. század végén égerlápos (Dryopteridi-Alnetum) területen alakítottak ki. A halastavak általában 1 méter mélységűek, felületük 83 ha, ennek kb. harmadát nádas (Scirpo-Phragmitetum) borítja. A területen folyó halastavi gazdálkodás extenzív. A tavakat fúz- (Calamagrosti-Salicetum cinereae) és égerlápok (Dryopteridi-Alnetum), valamint nagy kiterjedésủ gyertyános-tölgyesek (Fraxino pannonicae-Carpinetum) veszik körül, melyekben szigetszerüen bükkös (Leucojo verno-Fagetum) és cseres-tölgyes (Quercetum petraeae-cerris) foltok találhatók. A Boronka-melléki Tájvédelmi Körzetröl, ÁBRAHÁM (1992) által szerkesztett kötetben találhatók további részletek.

\section{Mike körzete}

Az aranysakál és vörösróka táplálék-összetételének tanulmányozása az aranysakál 1996-1998-as elterjedésének peremterületén történt. A vizsgált két egymással érintkező mintaterület (86. ábra a mellékletben) Somogy megye középső részén helyezkedik el. Mindkettő hullámos felszínű homokvidéken terül el, kiterjedése egyenként $25 \mathrm{~km}^{2}$, a két terület karaktere azonban eltérö. Az I. területen (Mike-Csököly), ahol az aranysakál és a vörösróka együtt élt, a szántóföldi müvelés volt a meghatározó mủvelési ág (3. térképmelléklet). Itt az erdők erősen szabdaltak, mozaikos jellegűek; domináns az akácerdő és az égerligeterdő, alárendelt a tölgyerdő. A terület jellegét színezik a vadföldek és a füves élőhelyek. A II. területen (Mike-Petesmalom-Lábod) összefüggő, nagy kiterjedésű erdők találhatók (3. térképmelléklet). Itt a tölgyek a jellemzóek, emellett nyárültetvény fordul még elő. A szántóföldek viszonylag kis területet borítanak. A terület színezó elemeit a természetvédelmi kezelésben levő vizes élóhelyek: eutróf halastavak, sásos, nádas élőhelyek jelentik. A múvelési ágak megoszlása az I., illetve a II. területen az alábbiak szerint alakult: erdő $(37,5$, ill. 65,5\%), szántóföld $(53,0$, ill. 24,5\%), füves terület és vadföld $(5,5$, ill. $0,5 \%)$, vizes élőhely $(0,5$, ill. $6,5 \%)$, gyümölcsös $(1,5$, ill. $1,0 \%)$, valamint lakott terület $(2,0$, ill. $2,0 \%)$.

\section{Kétúifalu körzete}

Az aranysakál magyarországi elterjedésének központjában, Somogy és Baranya megyék határán, az Ormánságban tanulmányoztam az aranysakál és a vele életközösségben előforduló vörösróka táplálék-összetételét. A Kétújfalu, Teklafalu, Lakócsa, Potony és Zádor községek által határolt, közel $10 \times 10 \mathrm{~km}$ kiterjedésű síkvidéki terület belsejében nem található település (87. ábra a mellékletben). A szántóföldek jelentős hányada parlag. A nagyrészt betyárkóróval (Erigeron spp.) borított földek többségén évek óta nem folyik gazdálkodás. A mintavételre kijelölt élőhelyek a Korcsina pataktól északra helyezkednek el, ahol elsősorban nagyvadgazdálkodást folytatntak. A táblákat és az árkokat sűrü, alig átjárható füz, kökény bozótosok szegélyezik. Az általában kis kiterjedésú, szabdalt erdők vegyes állományú kocsánytalan tölgyesek, de a közelben zárt erdőtömbök is találhatók. A vizes élóhelyek kiterjedése nem számottevő, a területet behálózó árkokban fóként télen és tavasszal víz áll. 
Látrány

A Látrányi Puszta Természetvédelmi Terület külső-somogyi dombok közé ékelődik. A száraz homokpuszta gyepek, nedves mocsárrétek, patak menti kaszálórétek, kis erdófoltok sok érdekes és ritka állat- és növényfajnak biztosítanak élőhelyet. Így például a területen költ a gyurgyalag, állandóan elófordul az ürge, a vidra; termőhelye a gyapjúsásnak, a kosboroknak, a leánykökörcsinnek. A mintagyújtés Látrány és Visz községek közötti területen, a Tetves patak mentén és hidak alatt zajlott.

\section{Örtilos, Dráva és Mura folyók}

Az örtilosi vasútállomástól (Szentmihályhegy) a Dráva és a Mura folyók torkolatáig terjedő, majd a Mura mentén folytatódó partszakaszon történt vidraürülékek gyújtése. A vízpart mentén puhafa ligeterdő, fóként mandulalevelü bokorfüzes (Salicaetum triandre) található. A kavicszátonyokat részben csigolya bokorfüzes (Salicetum purpurea) borítja, előforduló faj a csermelyciprus (Myricaria germanica). Az őrtilosi kavicsbánya tavak mentén, a területbejárások során vidra jelenlétre utaló nyomot nem sikerült találni. A gyorsan mélyülö tavakat nem övezi összefüggő vízparti növényzet.

\section{Gyékényes, Dombó csatorna}

A mintavételi hely Gyékényes mellett, a Dombó-csatorna hídja alatt, valamint a híd melletti partszakasz. A csatornapart füvesített, de fás szárú növényzettől mentes, rendszeresen karbantartják.

\section{Gyékényes, Lankóci-erdö}

Az állandóan vízzel borított termőhelyek jellemzô fás növénytársulása az égeres mocsárerdő (Carici pendulae-Alnetum). Ennek tömeges fafaja az enyves éger (Alnus glutinosa), jellemzó cserjéi a kányabangita (Viburmum opulus), a rekettyefüz (Salix cinerea), gyepszintjében gyakori a posványsás (Carex acutiformis). Az égeres mocsárerdőkhöz kapcsolódóan szintén állandóan vízzel borított nádasok és magassásos társulások is vannak, melyek egy része a csökkenő vízborításnak köszönhetően beerdősülöben van. A vizsgálati terület nagy kiterjedésében találhatók égerligetek (Carici pendulae-Alnetum, Paridi, quadrifoliae-Alnetum). Ezeknek talaján csak magasabb vízállás esetén van talajszint feletti vízborítás. Az égerligetek területén hajdani sekély folyó-mellékágak maradványai (morotvatavak) találhatók, melyek árokrendszerében az év nagy részében víz van. Az égerligeteknél magasabb térszíneken tölgy-köris-szil ligeterdők (Fraxino pannonicae-Ulmetum) akotják a természetes növénytakarót (JuHÁsz 1998). A Lankóci-erdőt északkeleten a Dombó-csatorna határolja. Az egyébként igen változatos és különleges élöhelyeken a degradáltság számos jele látható. A terület a Nemzeti Biomonitoring Rendszerbe tartozik.

\section{Berzence, Dombó-csatorna}

A mintavételi hely Berzence község közelében, a Dombó-csatorna hídja alatti terület, valamint a közvetlen közelében levő vízpart. A csatorna partja itt is füves, a mederben nád található. A csatorna mentén legelőre alapozott, állattartás folyik.

\section{Somogyudvarhely, Kavicsbánya tavak}

A szép környezetben elhelyezkedő kavicsbánya tavak horgászhasznosítás alatt állnak. A gyorsan mélyülő tavakat füzliget szegélyezi. 


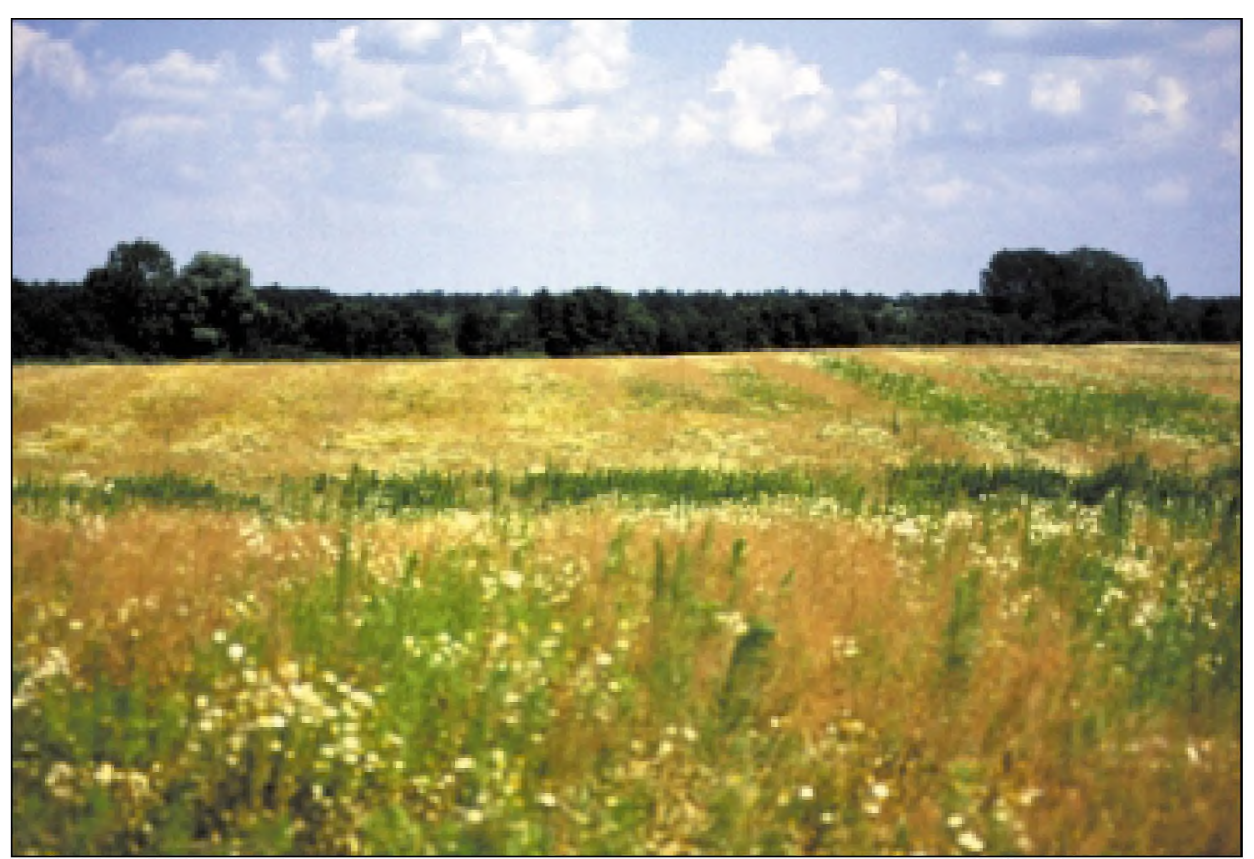

7. ábra: Jellegzetes élőhely a sakál elterjedésének központjában (Kétújfalu)

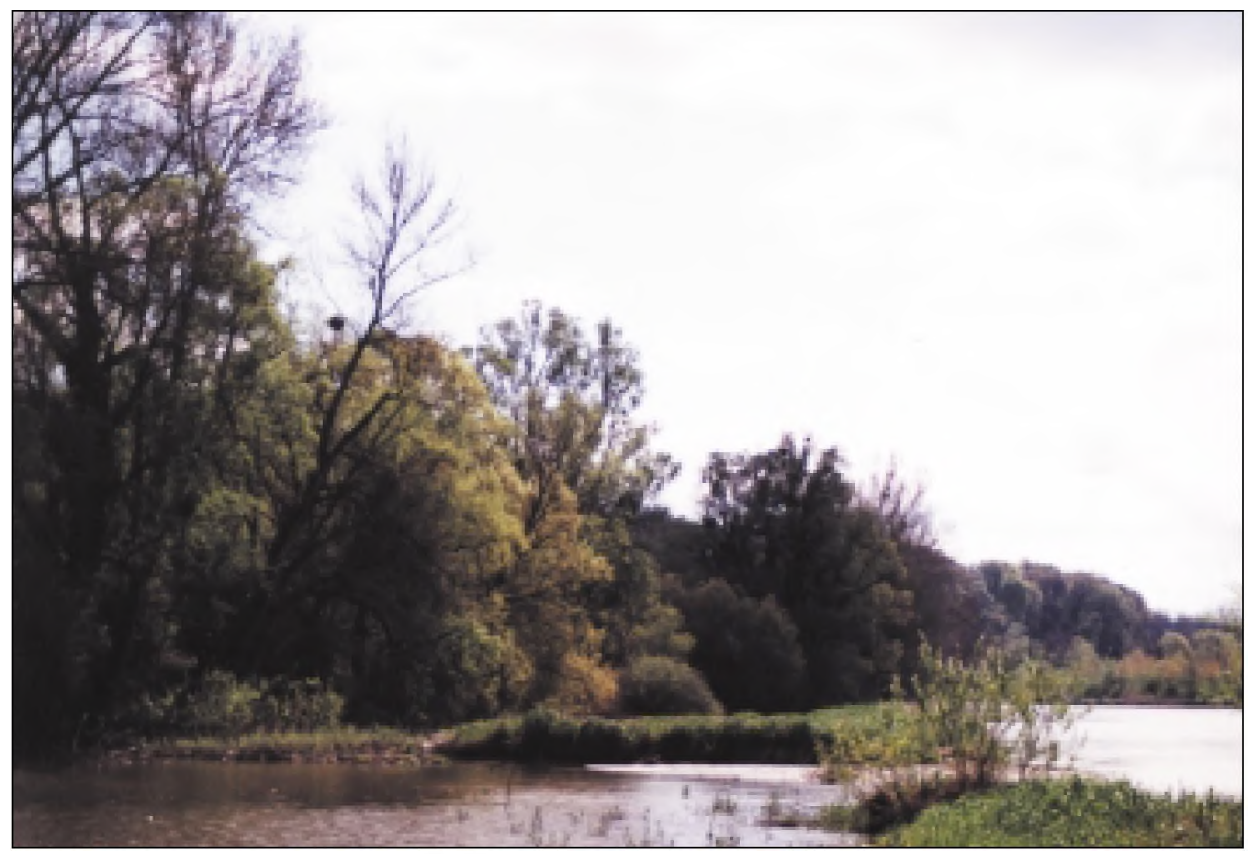

8. ábra: Örtilos-Szentmihályhegy, a Mura folyó 


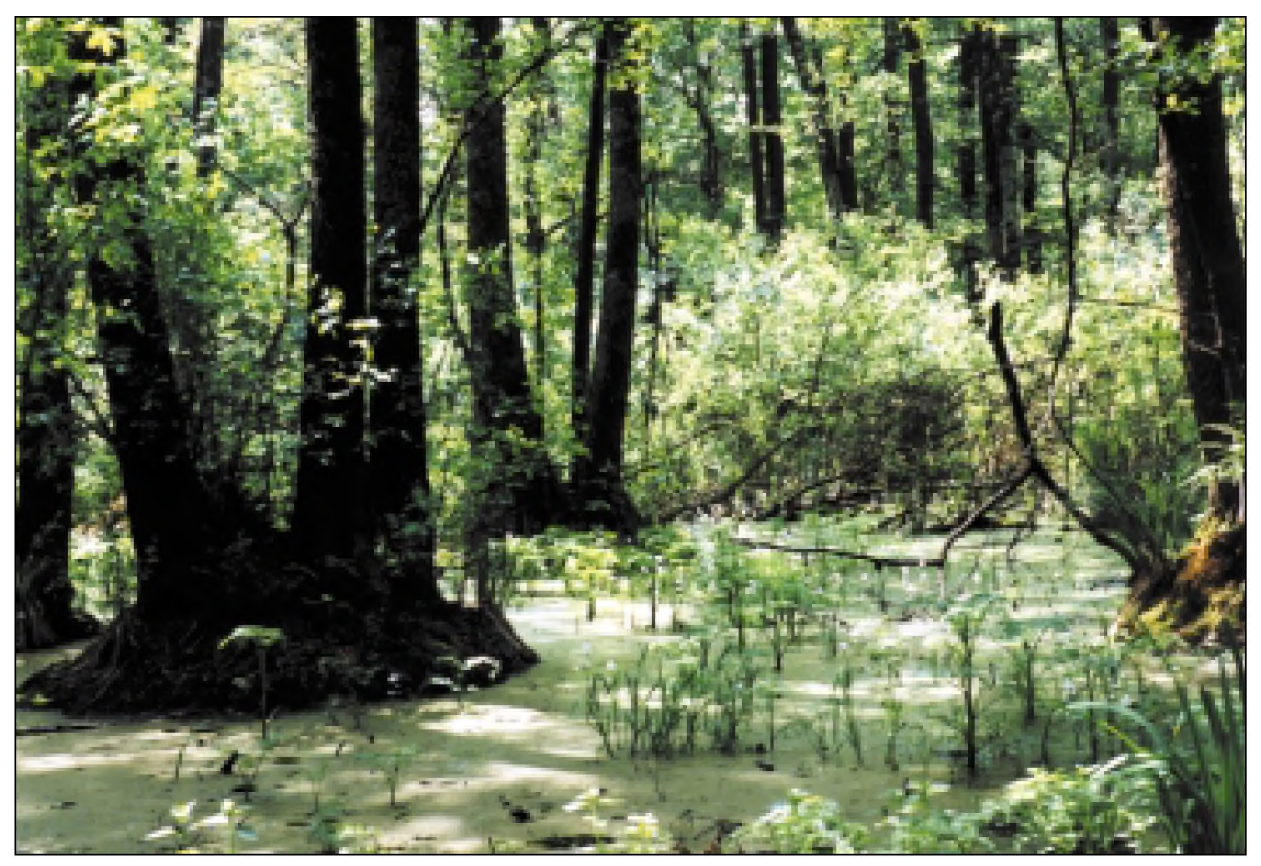

9. ábra: A Lankóci erdő fotó: Juhász Magdolna

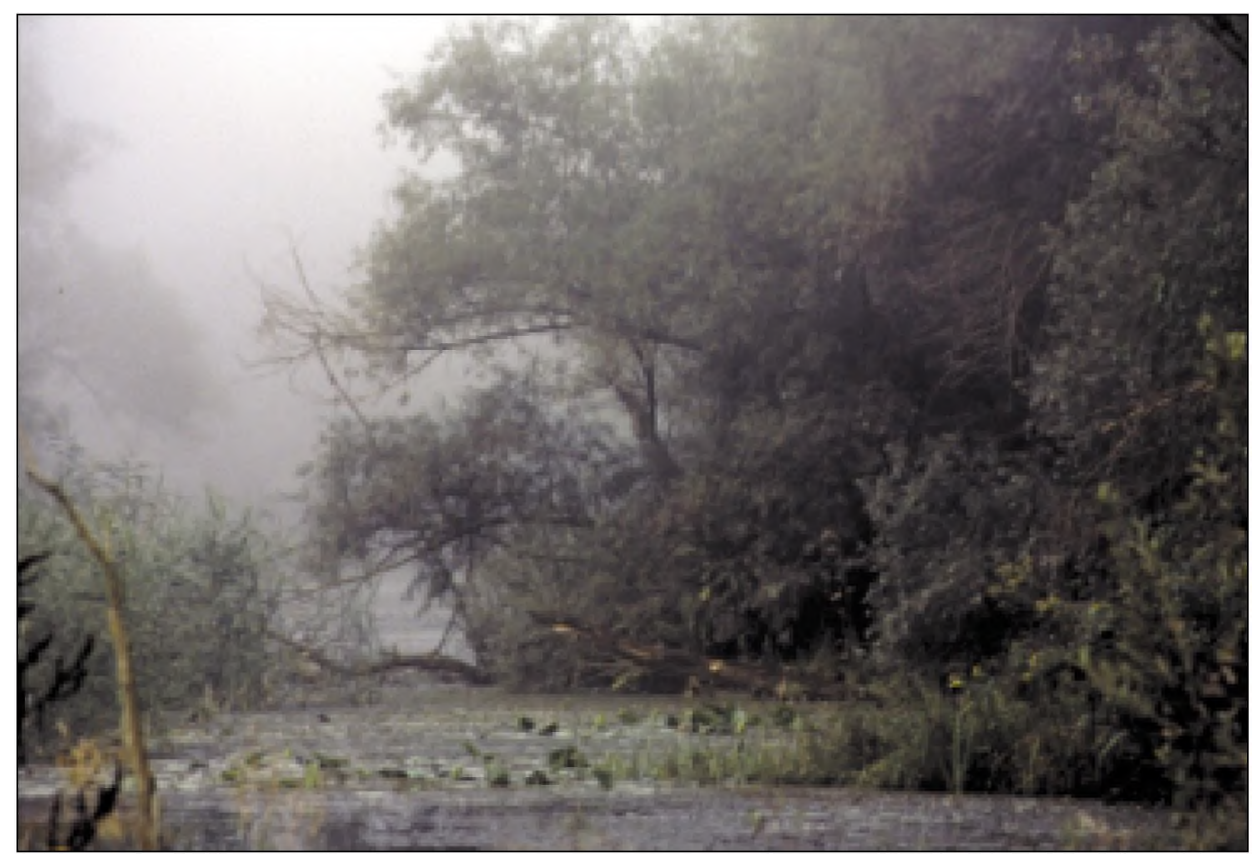

10. ábra: A bélavári holtág 
Bélavár, holtág

A mintavétel Bélavár község közelében, egy emberi zavarásnak alig kitett Dráva holtág mentén, valamint két kavicsbánya tavon pontszerűen történt. A sekély vizü holtágat háborítatlan puhafa ligeterdö övezi, erôteljes eutrofizálás jellemzi.

Vízvár, Dráva folyó

A folyót ártéri füzes és égeres ligeterdők övezik különleges értékét a kavicszátoinyok és azok élóvilága jelenti. A mintagyűjtés a part mentén és egy kôruganyon történt. Nyári időszakban intenzív víziturizmusnak kitett szakasz.

Babócsa, Erzsébet sziget

A mintagyüjtés a füz ligeterdôvel szegélyezett Ó-Dráva holtág mentén, valamint a közeli kubikgödrök partján zajlott. Nyáron, kevés csapadék esetén a holtág és a gödrök vízmélysége jelentős mértékben csökken. A kavicsgödröket sulyommező borítja. A határörizetnek köszönhetően zavartalan terület.

Babócsa, Rinya

A mintavétel a Babócsa melletti Rinya (patak) hídja alatti terület, valamint a közeli vízparton történt. A patakmederben foltokban nád található, partoldala füves. A terület antropogén zavarása kismértékú.

\section{Drávaszentes, Barcs-Komlósdi Rinya}

A mintavétel a Drávaszentes közelében folyó Barcs-Komlósdi Rinya hídja alatt és közvetlen közelében zajlott. A patakmeder nádassal benött, időszakosan kiszáradhat.

\section{Barcs, Kisbóki holtág}

A Drávától elszigetelődött morotva partját puhafa ligeterdő szegélyezi. A holtágat horgászattal hasznosítják, medre feltöltódőben van. A mintagyűjjtés a part mentén és horgász stégeken történt.

\section{Barcsi Borókás Tájegység, Középrigóci tavak}

A mintagyüjtés a Barcsi Borókásban kialakított egykori völgyzárógátas halastavak mentén zajlott. A vízpart közelében égeresek találhatók. A mintgyújtő útvonal kijelölése a tavak gátjain és a leeresztô zsilipek körüli kövezésen történt

\section{Lakócsa, Korcsina csatorna}

A csatorna a környező mezôgazdasági területeket behálózó árokrendszerből gyüjti össze a csapadékvizet és szállítja a Drávába. Aszályos időszakban a víz áramlása megszünik, a meder helyenként kiszárad. A patakmederben helyenként nádfoltok találhatók, csekély halállománnyal rendelkezik. A mintagyújtés Lakócsa határában a csatorna hídja alatt és közvetlen közelében levố vízparton zajlott. Ez a terület, a fenti Dráva menti területekkel szemben, nem része a Duna-Dráva Nemzeti Parknak. 


\section{Mintagyüjtés és feldolgozás}

Röviden célszerủnek tartom a táplálék-összetétel vizsgálatoknál alkalmazható módszerekröl néhány szót ejteni. A zsákmányszerzés közvetlen megfigyelése a növényzettel való fedettség miatt csak esetenként fordulhat elö. Ezért ez statisztikailag általában nem értékelhető, viszont háttér információként fontos lehet. A predáció tanulmányozása érdekében praktikus okok miatt más módszereket alkalmaznak. A ragadozók táplálék-öszszetételének és táplálkozási szokásainak vizsgálatára a gyomortartalom-, a zsákmánymaradvány, és a hullaték /ürülék/ elemzés alkalmazható. A gyomortartalom-vizsgálat előnye, hogy a zsákmány gyakran ép marad, amiból bizonyos táplálkozási szokásokra lehet következtetni (HYSLOP 1980). Ezt a módszert jobbára a vadászható, nem veszélyeztetett állatfajok esetében, valamint a nagy léptékü monitoring programokban alkalmazzák. A módszerek sokféleségét mutatja, hogy kutatónként is eltérések tapasztalhatók ezek alkalmazásában. JENSEN és SEQUIRA (1978) erdővel tarkított mezőgazdasági területekről származó rókák gyomortartalmát és kotorék melletti táplálékmaradványát elemezte. Lemérték a gyomortartalom súlyát, majd formalinban konzerválták, de nem vizsgálták faj szerint a gerincteleneket és a növényeket. Felhívták a figyelmet a gyomortartalom vizsgálatokból levont mennyiségi következtetések problematikájára. A különbözö idôt gyomorban eltöltő maradványok emésztettsége ugyanis különböző. A kvalitatív összetétel (százalékos relatív előfordulási gyakoriság, vagy előfordulási gyakoriság) alapján viszont nem lehet közvetlen következtetést levonni a tényleges táplálék-fogyasztásra. Ennek ellenére az azonos területről, több évszakból származó minták alapján a jellemző szezonális változások tendenciája kvalitatív adatsorból is jól leolvasható. Továbbá nagyon fontos az a megállapításuk, hogy az eltérő területekről származó minták öszszehasonlíthatók, amennyiben a mintagyüjtés körülményei azonosak. SUCHENTRUNK (1984) több éves idôtartamban róka gyomortartalom mellett, kiegészítő információ szerzése érdekében a tetemek végbéltartalmát is elemezte. Ez különösen abban az esetben lehet fontos, ha a gyomor üres. JENSEN és SEQUEIRA (1978) adatgyüjtéséhez hasonlóan FARKAS (1983) is gyomor- és táplálékmaradványt vizsgált. ERDEI (1977) viszont róka gyomortartalom és zsákmánymaradvány mellett ürüléket is elemzett. A zsákmányállat tetemek vizsgálata elsősorban a nagyragadozók táplálkozási szokásainak tanulmányozása során bevált módszer (pl. JEDRZEJEWSKI et al. 1993a).

A közepes és kistestű ragadozók vizsgálatára az előzőekben említett módszerek közül napjainkban a hullaték-analízist részesítik elönyben. Ennek természetvédelmi oka, hogy a védett és fokozottan védett fajok zavarás nélkül, hosszú időn át, ráadásul nagy számú minta alapján vizsgálhatók. Természetesen ez a módszer is hordoz hibákat (REYNOLDS és AEBISCHER 1991). Itt kell megemlíteni a madártojás fogyasztás mérésének problematikáját is. A tényleges fogyasztást ugyanis az ürülékben talált tojáshéj töredékek alapján valószínűleg alábecsüljük. A ragadozók a tojás feltörésekor, illetve tartalmának fogyasztásakor legfeljebb apró héjdarabkákat nyelnek le (ráadásul nem is minden esetben), a tojás tartalma pedig egyáltalán nem mutatható ki az ürülékből. A kutatónként is gyakran eltéró minta feldolgozási, csoportosítási és számítási módok nagyban megnehezítik a különböző területeken kapott eredmények összehasonlítását. Például a százalékos előfordulási gyakoriság közlésekor a kisebb táplálék taxonok (csoportok) túlbecslése valószínú (DAY 1968). Másrészt viszont, a taxononkénti (százalékos relatív elöfordulási gyakoriság) adatok összeadásakor 100\%-ot kapunk, a (százalékos elöfordulási gyakorisági) 


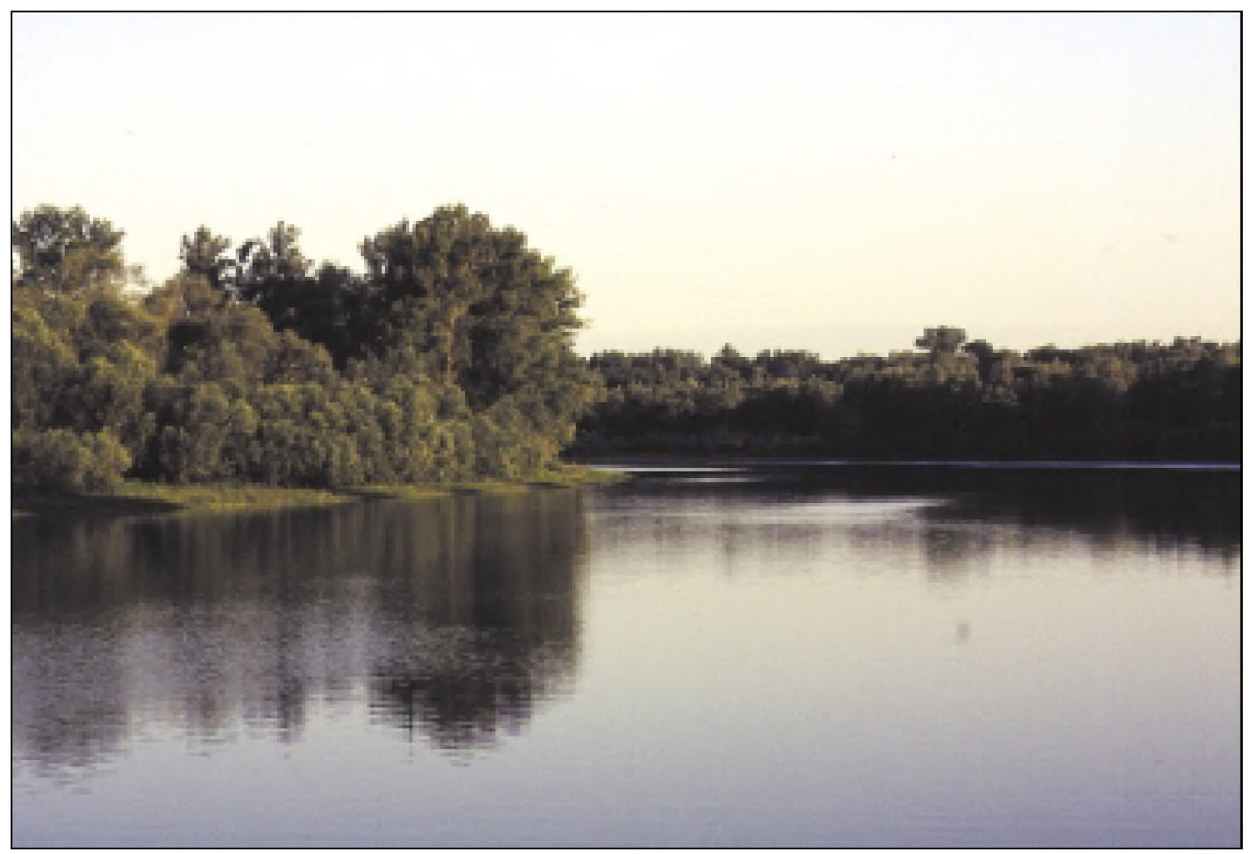

11. ábra: A babócsai Ó-Dráva

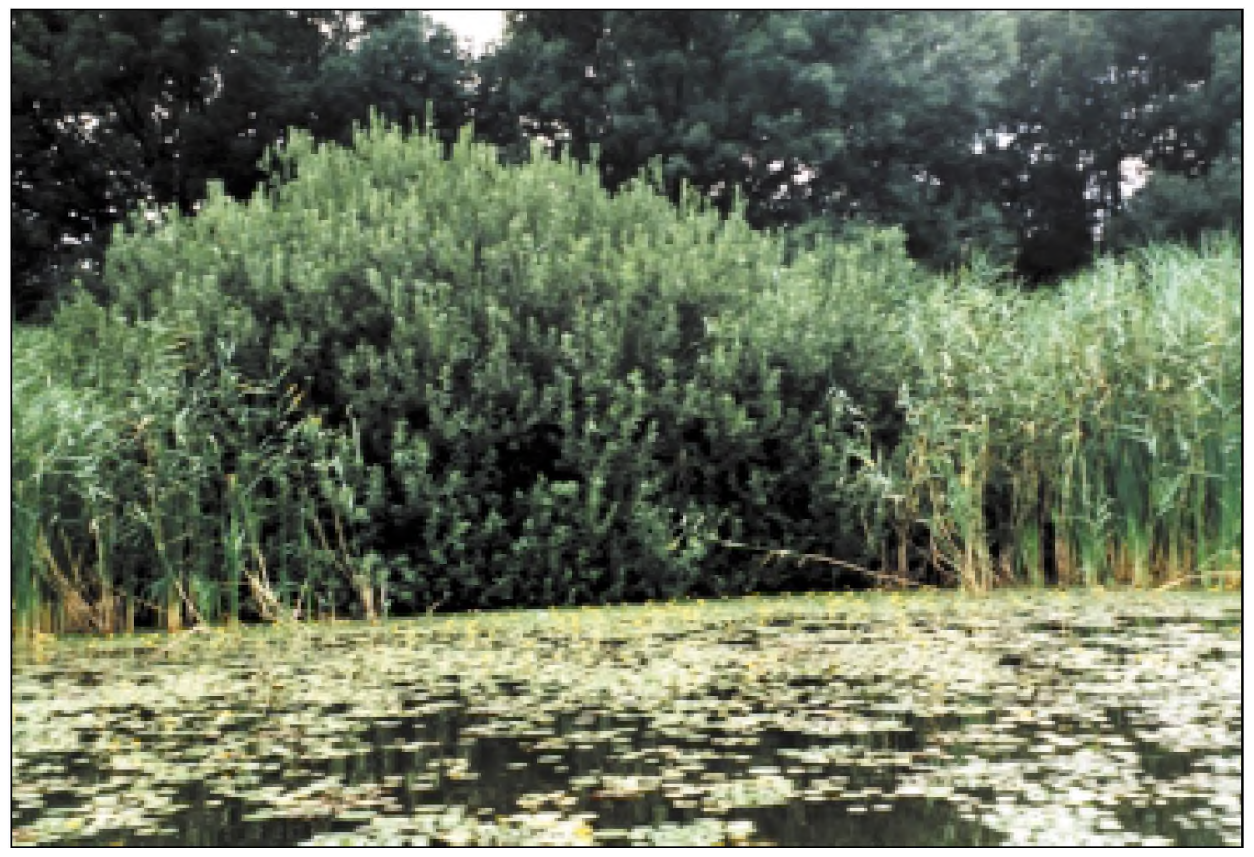

12. ábra: ......és az ártér fotó: Juhász Magdolna 


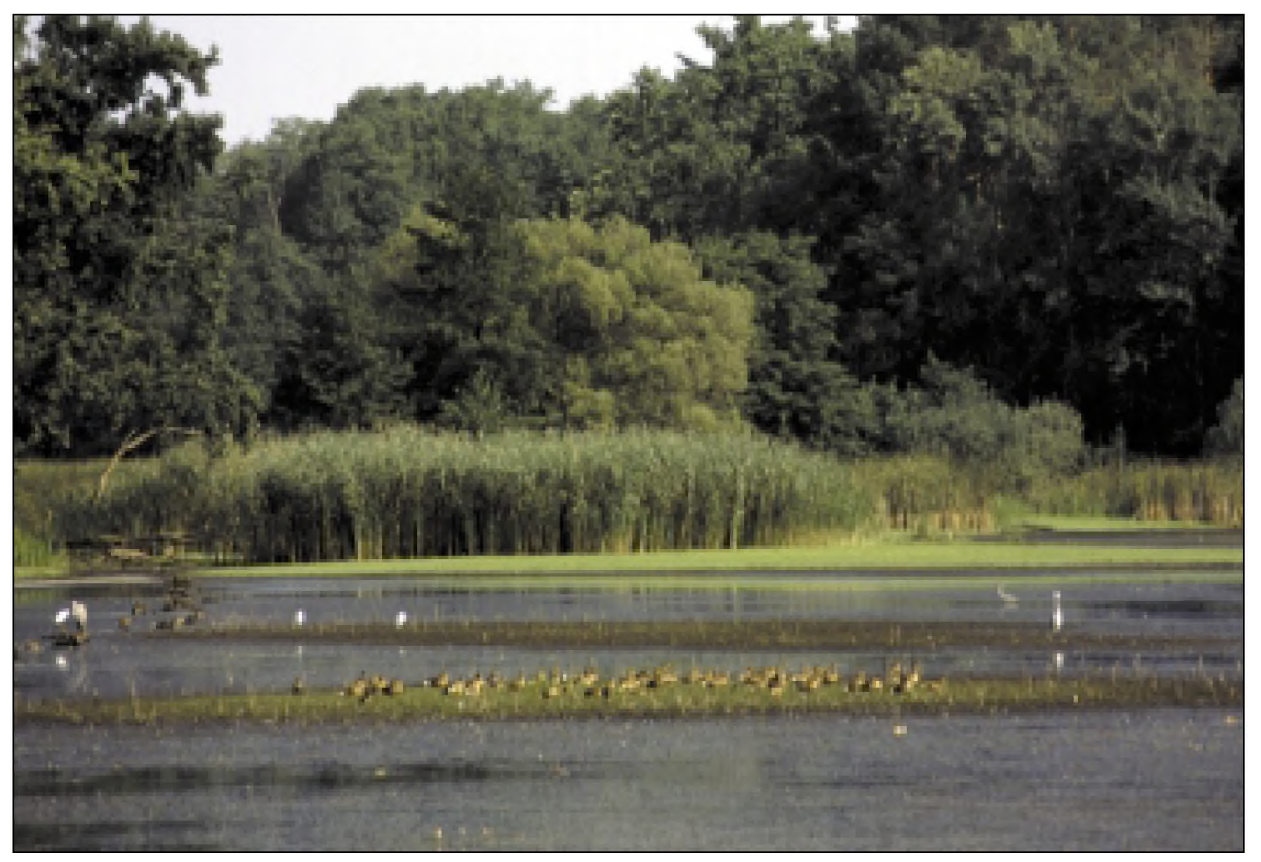

13. ábra: A Barcsi Borókás Tájegység egyik tava (Középrigóc)

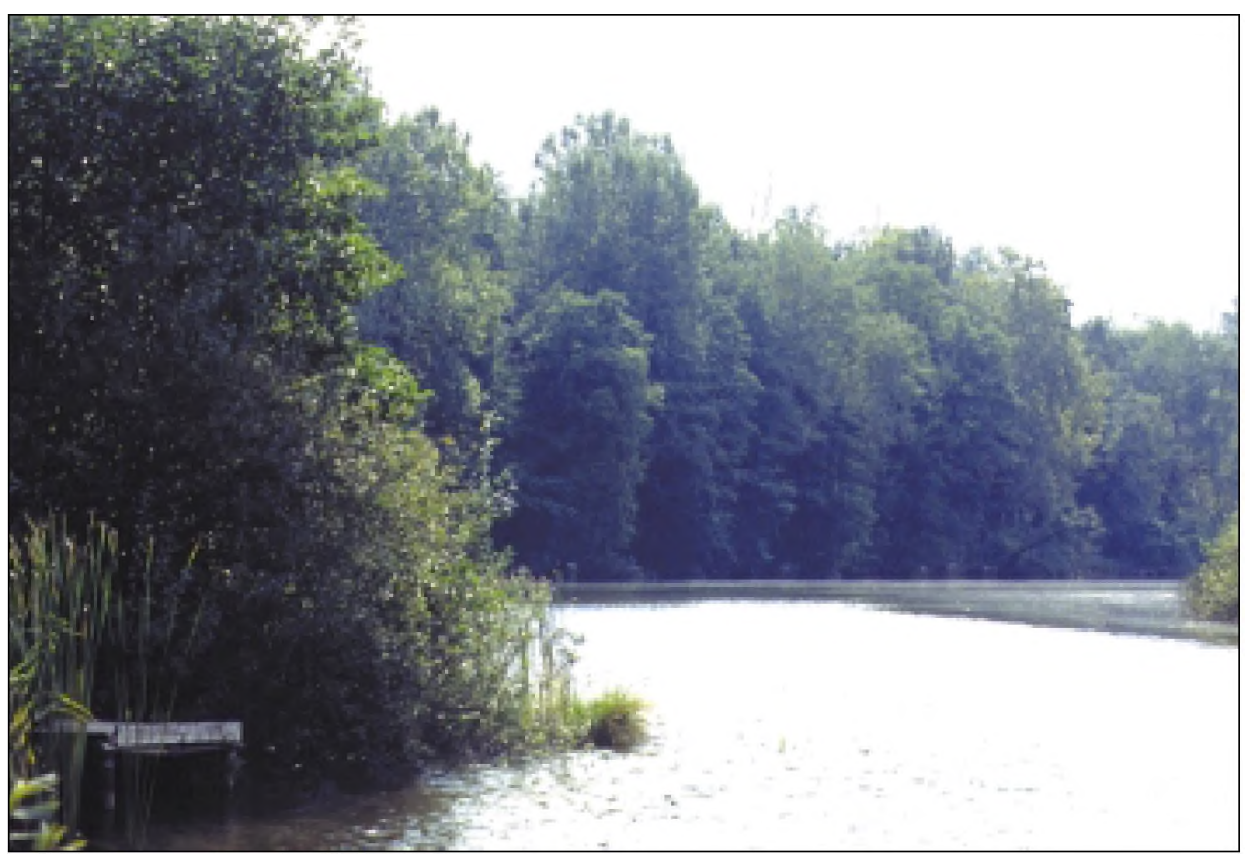

14. ábra: A Kis-bóki holtág 
adatok esetén viszont $100 \%$-nál nagyobb érték fordulna elő. Hogyan lehetséges ez? Ha például egy táplálék taxon mindegyik mintában előfordul, az már önmagában $100 \%$, és ehhez hozzájön még a többi táplálékféleség adata. Ezért is célszerủ a különböző kutatási eredmények átvételekor a feldolgozási módszertant figyelembe venni. A kutatási metodikák egységesülése még sokáig várat magára, ezért célszerü a vizsgálat céljainak legmegfelelőbb módszert kiválasztani.

\section{2. táblázat: A mintagyüjtés fôbb adatai}

\begin{tabular}{|c|c|c|c|c|c|c|}
\hline Terület & UTM kód & $\begin{array}{l}\text { Vizs gála } \\
\text { idōtartama }\end{array}$ & $\begin{array}{c}\text { Vonal- } \\
\text { transzekt, } \\
\text { méter }\end{array}$ & $\begin{array}{l}\text { Mintagy ûjtés } \\
\text { gyakorisága }\end{array}$ & Faj & $\begin{array}{c}\text { Minta- } \\
\text { szám }\end{array}$ \\
\hline \multirow[t]{5}{*}{ Fonói tó körzete } & YM24 & 1991-1997 & 1200 & 2 hét & vidra & 1942 \\
\hline & & 1991-1997 & 4200 & 2 hét & róka & 350 \\
\hline & & $1991-1997$ & 4200 & 2 hét & nyest & 572 \\
\hline & & $1991-1997$ & 4200 & 2 hét & borz & 71 \\
\hline & & 1991-1999 & 4200 & 2 hét & hermelin & 99 \\
\hline Fonó község* & YM24 & 1998 & pontszerû & & nyest & 151 \\
\hline \multirow[t]{4}{*}{ Boronka-melléki TK.** } & XM84, XM94 & $1996-1998$ & 4200 & 1 hónap & vidra & 1280 \\
\hline & & $1996-2001$ & 5000 & 1 hónap $/ 2$ hét & róka & 1010 \\
\hline & & $1996-2001$ & 5000 & 1 hónap/2hét & nyuszt & 332 \\
\hline & & $1996-2001$ & 5000 & 1 hónap $/ 2$ hét & borz & 156 \\
\hline Õrtilos, Dáva és Mura foly ók & $\mathrm{XM} 42, \mathrm{XM} 43$ & $2000-2001$ & 1300 & 6 hét & vidra & 159 \\
\hline Gyékényes, Dombó-csatoma & XM52 & $2000-2001$ & 600 & 6 hét & vidra & 157 \\
\hline \multirow[t]{4}{*}{ Gyékényes, Lankóci-erdõ } & XM52 & $2000-2001$ & 2000 & 6 hét & vidra & 116 \\
\hline & & $2000-2001$ & 2000 & 6 hét & róka & 251 \\
\hline & & $2000-2001$ & 2000 & 6 hét & nyuszt & 271 \\
\hline & & $2000-2001$ & 2000 & 6 hét & hermelin & 30 \\
\hline Berzence, Dombó-csatorna & XM61 & $2000-2001$ & 200 & 6 hét & vidra & 131 \\
\hline Somogy ud varhely, kavics bány a tavak & XM61 & $2000-2001$ & 2000 & 6 hét & vidra & 54 \\
\hline Bélavár, holtág & XM70 & $2000-2001$ & 500 & 6 hét & vidra & 217 \\
\hline Vízvá, Dráva folyó & XM70 & $2000-2001$ & 1500 & 6 hét & vidra & 109 \\
\hline Babớsa Ó-Dráva & XL79 & $2000-2001$ & 1600 & 6 hét & vidra & 215 \\
\hline Babócsa Rinya & XM80 & $2000-2001$ & 400 & 6 hét & vidra & 303 \\
\hline Drávaszentes, Barcs-Komlósdi Rinya & XL 89 & $2000-2001$ & 200 & 6 hét & vidra & 76 \\
\hline Barcs, Kis-bóki holtág & XL99 & $2000-2001$ & 1000 & 6 hét & vidra & 69 \\
\hline Barcs, halastavak & XL99 & $2000-2001$ & 2000 & 6 hét & vidra & 605 \\
\hline Lakócsa, Korcsina-csatorna & XL08, XL18 & $2000-2001$ & 200 & 6 hét & vidra & 96 \\
\hline \multirow[t]{2}{*}{ Mike-Csōköly *** } & XM92 & $1996 / 97$ & 6700 & 1 hónap & sakál & 24 \\
\hline & & 1997/98 & 6700 & 1 hónap & róka & 11 \\
\hline \multirow[t]{2}{*}{ Petesmal om } & XM92 & $1996-1998$ & 6200 & 1 hónap & róka & 77 \\
\hline & & 1996-1998 & 6200 & 1 hónap & vidra & 801 \\
\hline \multirow[t]{2}{*}{ Kétúj falu körzete e*** } & YL 08,YL 09, & $2000-2001$ & $9000 / 12800$ & 6 hét/1 hớnap & sakál & 330 \\
\hline & YL18, YL19, & $2000-2001$ & $9000 / 12800$ & 6 hêt/1 hớnap & róka & 300 \\
\hline Látrány, Tetves patak ****** & YM17, YM18 & 2001 & 1300 & 6 hét & vidra & 115 \\
\hline
\end{tabular}

* Az "urbánus" nyesttôl származó minták gyưjtése egy alkalommal történt a malom épületében, a minták feltételezhetóen több évból származtak.

** A mintagyữjtés 1997-ben havonta, majd 2001 februárig havonta kétszer történt.

*** A mintagyưjtés 1996 december és 1997 április, valamint 1997 december és 1998 április közötti időszakban történt.

**** A bejárt útvonal hosszúsága 2000-ben-ben rövidebb volt, mint 2001-ben.

****** A mintagyủjtés 2001 májustól novemberig zajlott. 
A jelen tanulmányban, a ragadozók táplálék-összetételétének vizsgálatára a hullaték (ürülék) elemzést választottam. A mintavételi gyakoriság és a bejárt útvonal hossza területenként eltéró volt, melyet a 2. táblázat foglal össze.

A különböző fajok ürülékének elkülönítése friss állapotban, a fajra jellemző szag, valamint méret alapján történt. A 2-3 naposnál régebbi minták elkülönítését méret és forma alapján végeztem (18. ábra). Ez a besorolás az esetek többségében elegendő volt. Azonban a faji hovatartozás alapián, bizonytalan eredetủ mintákból, az ürülékben található, tisztálkodás során lenyelt ragadozó szőröket morfológiailag is vizsgáltam. Mindezek után a terepen gyưjtött mintáknak kb. 3-5\%-a kérdéses (meghatározhatatlan) maradt, melyeket a feldolgozásból kizártam.

A táplálék taxonok meghatározása az emlősöknél koponyacsontok és fogazat (SCHMIDT 1967, MÄrZ 1972, GörNER és HACKETHAL 1987, UJHELYI 1989, saját referencia gyüijtemény), és szörmorfológia alapján történt. Ez utóbbi esetben speciális technika alkalmazása szükségszerủ. A kis- és közepes testméretű ragadozók hullatékában viszonylag ritkán találhatók fogak és koponyacsontok, ezért a határozásra legalkalmasabb, emésztés során épen maradt maradványok a szőrszálak. A hullatékban talált szőrszálak közül 4-5 fedőszőrt gyủjtöttem ki, majd ezeket tárgylemezre, vékony rétegben kent 5\%os meleg zselatin-oldatra helyeztem. A zselatin megszáradása után a szórszálakat lehúzva, 400×-os nagyítású fénymikroszkóp alatt vizsgáltam a kutikula mintázatot. Kérdéses esetben a tárgylemezen hagyott szőrök medulla mintázatát, valamint előkészítést követően a keresztmetszetét is figyelembe vettem. A határozáshoz szőrhatározó atlaszokat (DEBRot et al. 1982, TEERINK 1991) és saját referencia gyüjteményt alkalmaztam.

A madaraknál toll és koponyacsontok (BRown et al. 1993, saját referencia gyűjtemény), a hüllő́knél szarupikkelyek és csontok (DELY 1983), a kétéltúeknél csontok (PAUNOVIC 1990), a halaknál pikkely, garatfog és koponya csontok (BERINKEY 1966, PINTÉR 1989, KEMENES 1993, KNOLLSEISEN 1996, saját referencia gyűjjtemény), a gerincteleneknél kültakaró (pl. Móczár 1969) alapján történt a határozás. A növények, különösen a magvak határozását Soó és KÁRPÁTi (1968) munkája alapján végeztem. A bogarak egy részének határozásában közremüködött Rozner György, a rákoknál Körmendi Sándor, a növényeknél Juhász Magdolna.

A táplálék-összetételt és a táplálkozási niche-átfedést a hullatékokban előforduló táplálék taxonok relatív előfordulási gyakorisága alapján számítottam ki, melynek kifejezése a minimális egyedszám alapján történt. A (százalékos) relatív előfordulási gyakoriság számításmódja a következö:

100x(adott táplálék taxon példányainak száma)/(az összes táplálék taxon példányainak száma).

A százalékos relatív előfordulási gyakoriság mellett a fogyasztott táplálék biomassza szerinti összetételét is kiszámoltam, az alábbi módszerrel. A nedves technikával elókészített, $0,5 \mathrm{~mm}$-es lyukbőségü szitán átmosott, majd szárított táplálékmaradványokat $0,01 \mathrm{~g}$ pontossággal lemértem. Az egyes táplálékmaradványok súlyát ragadozó fajonként, JEDRZEJEWSKA és JEDRZEJEWSKI (1998) által összefoglalt faktorszámokkal szoroztam (3. táblázat).

A borz táplálékának vizsgálatakor nem lehet eltekinteni a földigiliszta előfordulásának meghatározásától és biomasszájának számításától. Ennek érdekében JEDRZEJEWSKA és JEDRZEJEWSKI (1998) leírása alapján a száraz mintákból 0,1 g-ot vettem ki és zselatin oldattal ellátott tárgylemezre szórtam vékony rétegben. Ezután a földigiliszták (tü)sertéit mikroszkóp alatt megszámláltam. A serték sárgás vagy barnás színú, hosszúkás, üvegszerü, mindkét végükön elhegyesedő, kissé ívelt képződmények. KRUUK (1989) és JEDRZEJEWSKA és JEDRZEJEWSKI (1998) útmutatása alapján az átlagosan 2,5 gramm súlyú 


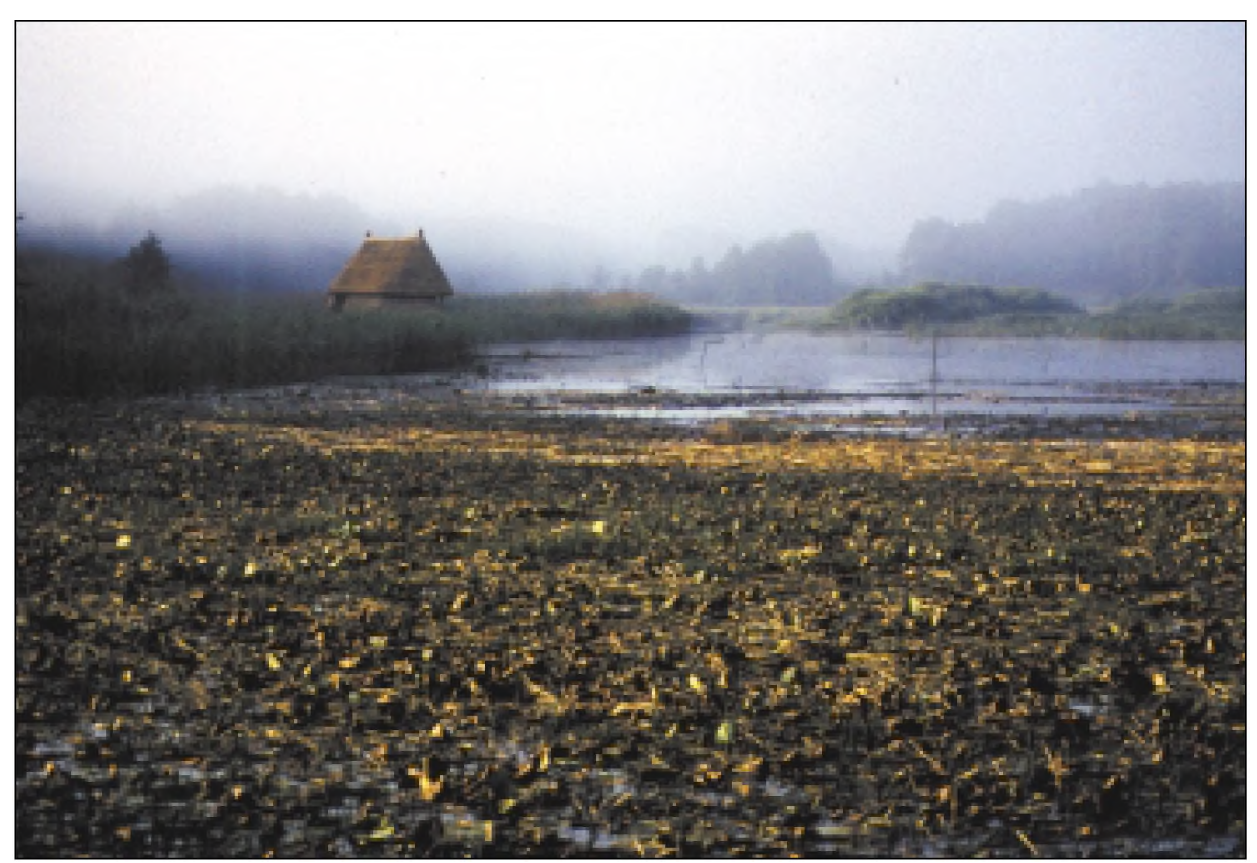

15. ábra: Boronkai hajnal

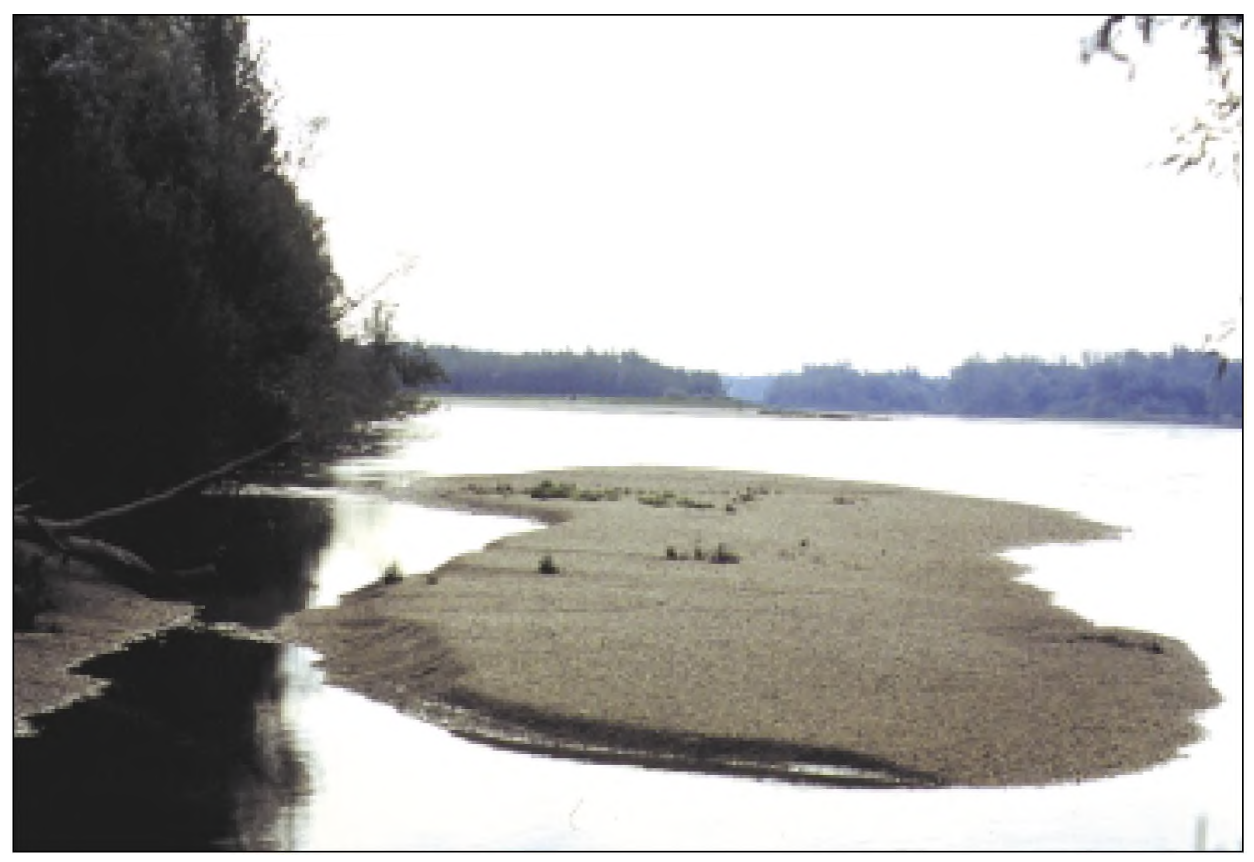

16. ábra: A Dráva folyó Vízváron 


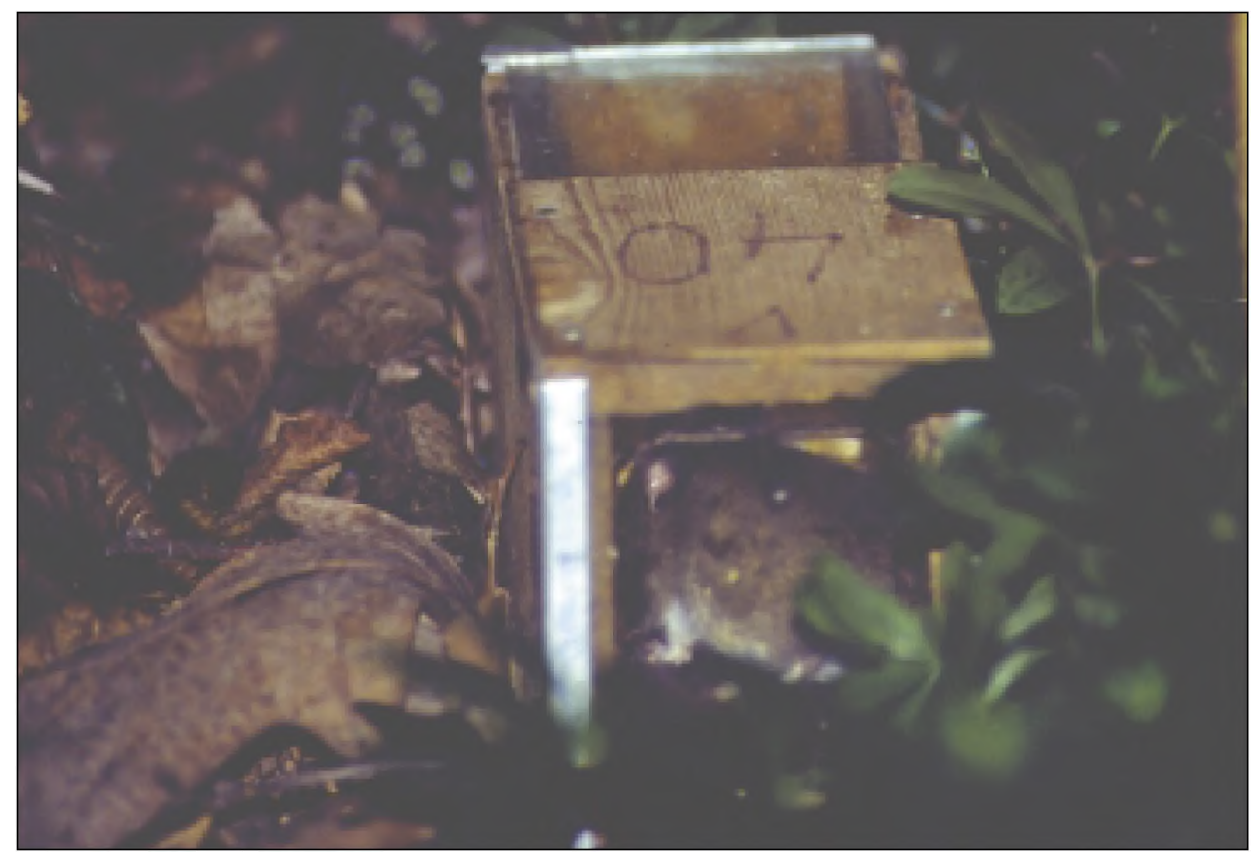

17. ábra: Kisemlős élvefogó csapda

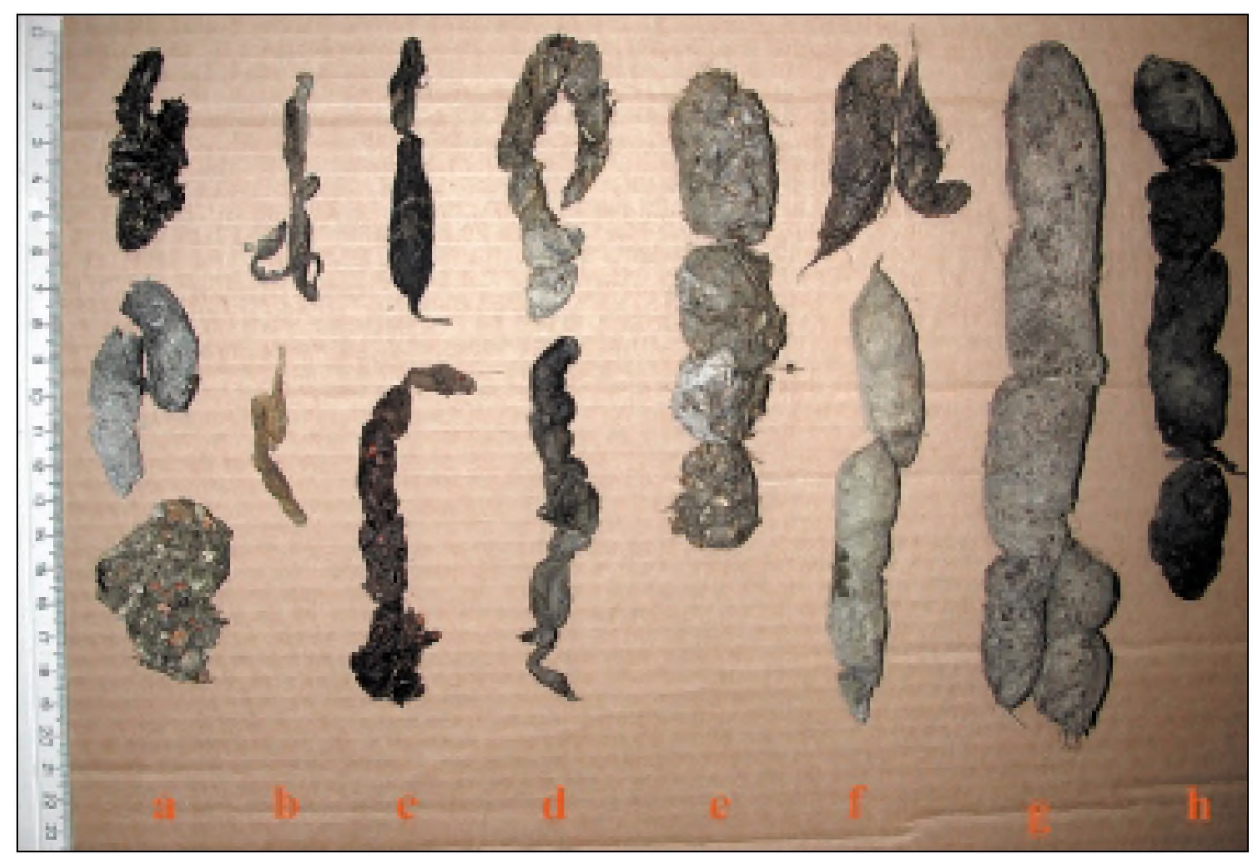

18. ábra: Ragadozó emlősök hullaték-sorozata: a) vidra, b) hermelin, c) nyest, d) nyuszt, e) borz, f) vörösróka, g) és h) aranysakál 
3. táblázat: Különböző ragadozó emlősök által fogyasztott táplálék maradványainak biomassza számításához használt faktorsúlyok * (összefoglalta: JEDRZEJEWSKA és JEDRZEJEWSKI 1998)

\begin{tabular}{|c|c|c|c|c|c|}
\hline 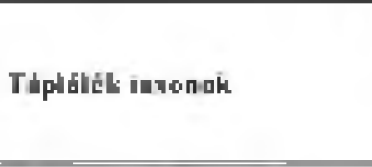 & $\begin{array}{c}\text { Farkas, } \\
\text { h'in }\end{array}$ & 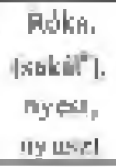 & $\begin{array}{c}\text { Htile, } \\
\text { nyestkurys }\end{array}$ & 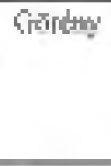 & 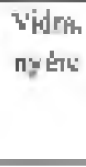 \\
\hline 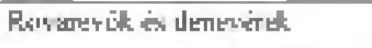 & 23 & 23 & 25 & 157 & 5 \\
\hline 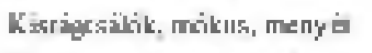 & 2.1 & 2.1 & 23 & 178 & 4 \\
\hline 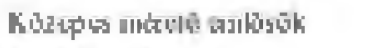 & 51 & 5 & 50 & & 25 \\
\hline Csūlsois vad & 118 & & & & \\
\hline "Wabligand Leteme" & & 119 & I1月 & 119 & \\
\hline 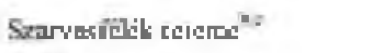 & & 15 & 15 & 15 & \\
\hline 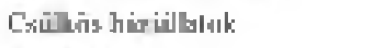 & 115 & 118 & IIH & & \\
\hline M ailarak: & 31 & 31 & $\$ \$$ & 124 & 12 \\
\hline Hïllōk kctèltôck & L8 & LI8 & 4는 & 41_3 & L8 \\
\hline Ilulall & & & 25 & 25 & 75 \\
\hline 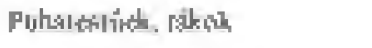 & $\vdots$ & $\$$ & 7 & 7 & $t$ \\
\hline Ravar & 5 & 5 & 5 & 5 & 5 \\
\hline 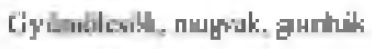 & & 14 & 14 & & \\
\hline 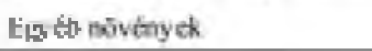 & 4 & 14 & + & 14 & 4 \\
\hline
\end{tabular}

Megjegyzések:

* a faktorok a hullatékban található maradványok száraz súlyán alapulnak.

a Az aranysakál besorolása a vörösrókához hasonló testsúlya és életmódja alapján történt. Az eredeti múben nincs utalás erre (Szerzó megjegyzése).

b A vaddisznó és a szarvasfélék fogyasztása a közepes és kistestú ragadozók által feltételezhetően az esetek többségében elhullott példányokból történt.

c A muflonnal végzett számítások a szarvasfélék kategóriájánál leírtak szerint történtek az Északi-középhegységben éló farkas és hiúz esetén, melyekre vonatkozóan rövid közlés található a tanulmányban. Az eredeti müben nincs utalás muflonra (a szerző megjegyzése).

gilisztánként 1000 serte számolható. A borz hullaték (eredeti) száraz és szitasoron átmosott, majd szárított súlya közötti különbség képezte a földigiliszta fogyasztott biomassza számításának alapját.

A mintákban talált emészthetetlen (általában szervetlen anyagot), valamint a vizsgált ragadozótól származó (1-5db) szőrszálat, amelyeket tisztálkodás során, tehát nem táplálékként nyeltek le, nem vettem figyelembe a számításoknál. 


\section{A táplálék-források felmérésének módszerei}

Az elsődlegesen fontos (domináns) táplálék-készletek felmérése a vidra halpreferenciájának, valamint egyes szárazföldi ragadozók kisemlős preferenciájának vizsgálata érdekében történt.

\section{A haltáplálék-készlet felmérése és csoportositása}

A haltáplálék felmérése az év végi (novemberi) lehalászási eredmények alapján zajlott a Fonói tavon az I. és III. időszakban, valamint a Boronka-melléki Tájvédelmi Körzetben. A Fonói tavon a II. idószakban a novemberi emelőhálós próbahalászattal becsült mennyiséget határoztam meg. A lehalászások végén apró lyukböségű $(1 \mathrm{x} 1 \mathrm{~cm})$ hálóval történt a húzás a kínai razbóra és más tógazdasági szempontból kedvezötlen megítélés alá eső halak számának alapos gyérítése érdekében. A lehalászási lista alapján a halfajok tömege szerinti százalékos gyakoriságból számoltam a haltáplálék-készlet biomasszáját. A fajonkénti egyedi haltömegekkel végzett számítás során kaptam az előfordulás szerinti százalékos relatív gyakoriságot, ami az egyes fajokhoz tartozó halak darabszámának arányát fejezi ki. A számítás módja a következô: a lehalászáskor mért halfaj (korosztály) bruttó súlya osztva az egyedi átlagos súllyal.

A haltáplálék-készletben, illetve a vidra haltáplálékában előforduló halfajokat és korosztályokat minden évben azonos módon osztályoztam súlyuk és preferált elöfordulásuk szerint (BERINKEY 1966; KEMENES és NECHAY 1990), referencia garatfog, koponyacsont és pikkelygyüjtemény felhasználásával. A halak súlykategóriái az alábbiak voltak:

1 - 50 g alatt,

2 - 50-100 g,

$3-100-500 \mathrm{~g}$,

$4-500-1000 \mathrm{~g}$,

$5-1000 \mathrm{~g}$ felett.

A halfajok és korosztályok jellemzô előfordulási régiója szerinti besorolás a vizsgált halastavak vízterében a következők szerint történt:

P - partközeli;

V - vízinövények között, elsősorban partközeli hínártársulásban;

$\mathrm{N}$ - nyíltvízi;

F - vízfenéki, vízfenék közeli vízrétegben.

A Fonói tavon, a II. időszakban a tó vízzel való feltöltése nem történt meg, ezért a halak élőhelye alapján végzett preferencia számításban ez az időszak nem szerepel.

\section{A kisemlösök elevenfogó csapdázása és csoportosítása}

A Boronka-melléki Tájvédelmi Körzetben 1998 április és 2001 február között végeztük egyetemi hallgatók közremüködésével a kisemlős készlet felmérését. Elevenfogó csapdázás módszerét alkalmaztuk (DEMETER és Kovács 1991, CsorBa és PECSENYE 1997, HoRvÁTH 1999). A mintavétel havonta illetve kéthavonta, összesen 26 periódusban zajlott. Periódusonként 4 éjszakára helyeztük ki a csapdákat. A mintavétel egy 10x10-es és egy 7x7-es minta kvadrátban történt (85. ábra a mellékletben), összesen 149 db csapdával. A csapdaéjszakák száma 15496 volt. A csapdákkal lefedett mintaterület 
összesen kb. 1,5 hektárt jelentett. A kvadrát rácspontjait 10 méterenként, számozott lécekkel jelöltük ki a mintavételi időszak elött és adott számozású csapdát a továbbiakban mindig a saját rácspontjához helyeztünk. Hagyományos üvegajtós facsapdát alkalmaztunk, melynek mérete $180 \times 70 \times 70 \mathrm{~mm}$ volt. Csaléteknek diót, kukoricát és szalonnát használtunk. A csapdák ellenörzése kora reggel és este (sötétedés után) történt, melyet már a kihelyezés estéjén is elvégeztünk. A befogott kisemlösök egyedi jelölése a rágcsálóknál elterjedten alkalmazott ujjperc levágással történt (CSORBA és PECSENYE 1997). Befogás után a faj határozásán kívül súlymérést, ivar, kor (juvenilis, adult) és reprodukciós állapot (vemhes, szoptató) felvételét végeztük.

A havonkénti csapdázási eredmények alapján a legkisebb ismert egyedszámot határoztam meg, mely tartalmazza 1) az új befogott, 2) a visszafogott, valamint 3) a területen jelen levő, de csak későbbi időpontban visszafogott egyedek összesített számát.

A havonkénti adatokból az elöforduló kisemlős csoportok százalékos megoszlását kiszámoltam. Ezeket az adatokat használtam fel a szárazföldi ragadozók kisemlős-preferenciájának számításakor. A kisemlős csoportok kialakítása az alábbiak szerint történt: 1 . erdei pocok, 2. erdeiegér faj-együttes: közönséges erdeiegér + sárganyakú erdeiegér + pirókegér együttesen, 3. cickányfélék és 4 . pelefélék. A cickányfélék és pelefélék adatai csak tájékoztató jellegüek, ugyanis az alkalmazott csapdázási metodika elsősorban talaj közelben lakó rágcsálók fogására alkalmas.

Kétújfalu körzetében az aranysakál és a vörösróka domináns táplálék-készletének felmérése érdekében 2001 októberében zajlott kisemlösök csapdázás, a Boronka-melléki Tájvédelmi Körzetnél ismertetett csapda típussal és módszerrel. A mintavétel négy éjszakás periódusban, egy $10 \times 10$-es és egy $7 \times 7$-es kvadrátban történt. Az alkalmazott csapdák száma összesen $149 \mathrm{db}$ volt. A 10x10-es kvadrátot több éve parlagon álló területen, a 7x7-es kvadrátot pedig egy erdófoltban állítottuk fel. A minimális egyedszám (MNA) meghatározás mindössze az új befogott egyedek összesített száma alapján történt. A kisemlős csoportok a következók voltak: 1. mezei pocok, 2. erdei pocok, 3. erdeiegér faj-együttes (közönséges erdeiegér + sárganyakú erdei egér + pirókegér) és 4. cickányfélék.

Az erdei egerek faj-együttesben való csoportosításának oka, hogy az egyes egérfajok a ragadozók ürülékében található szőrszálak alapján nem minden esetben különíthetôk el.

A prédaként szereplö fajokat súlyuk (CLEVENGER 1993a) és ragadozó fajokra leírt jellemző előfordulási zónájuk alapján (GITTLEMAN 1985) soroltam be. A táplálék taxonok listája és besorolása a 2 . mellékletben található meg. 


\section{Az alkalmazott számítások és statisztikai módszerek}

\section{Táplálkozási niche}

Az ökológiai niche témakört általánosságban és csak nagyon röviden foglalhatom öszsze, de ez mégis szükséges annak érdekében, hogy a tanulmányban alkalmazott számítási módszerek könnyebben áttekinthetôk legyenek.

Magát a niche fogalmat számos értelmezésben használták az elmúlt közel száz évben. Eredeti jelentésében a niche az a tér (füllke), amelyet egy faj populációja funkcionálisan elfoglal. Ma leginkább a hutchinsoni niche koncepció elfogadott. Eszerint minden faj a maga egyedülállóan jellemezhető niche-ével rendelkezik, mely a teljes, vagy korlátozó tényezók nélkül megvalósuló ún. fundamentális (vagy virtuális) niche. A niche a biotikus és abiotikus tényezők sorának olyan kombinációját jelenti, amelyeknek szélsô pontjait az adott szervezet tolerancia-határai jelölik ki a szóban forgó dimenziók vonatkozásában. Mivel a tényezók száma elvileg végtelen, így a modell szerint a niche-fogalom $n$-dimenziós hipertérként értelmezhetó, melynek minden egyes dimenziója egy-egy hatótényezö. A valóságban a hatótényezők száma nem végtelen, hanem korlátozott. A legföbb korlátokat a hasonló, vagy közel hasonló tolerancia határokkal rendelkező populációk jelentik, emiatt a fundamentális niche nem valósulhat meg. Helyette a gyakorlatban a populáció az ún. realizált (vagy aktuális) niche-sel rendelkezik, mely a fundamentálisnak azon részét jelöli, amely az adott körülmények között létezhet. A populációk alkalmazkodnak a környezet adottságaihoz és az evolúció útján fajspecifikussá vált környezeti igényeik létrehozzák a niche-kihasználási mintázatot. Ennek fó jellemzői megszabják a niche kiterjedését, vagyis a niche-szélességét (a realizált niche-re vonatkozó részt). A föbb igények niche-tengelyre vetíthetơk. A különbözó populációk a nichetengely eltérő hosszúságú szakaszait veszik igénybe. A fajok niche-e különböző lehet a táplálékkészlet kihasználása tekintetében, aszerint, hogy táplálékspecialisták, vagy sokféle táplálékon éló generalisták. Az utóbbiak a tengely teljes hosszát lefoglalják, jobban tudnak alkalmazkodni a változó viszonyokhoz.

Ha két populáció niche-e, vagyis ökológiai környezet iránti igénye teljesen megegyezik, akkor hosszabb ideig nem képesek egymás mellett élni (kompetitív kizárás elve). Ilyen eset figyelhető meg a Balkán félszigeten a farkas és a sakál között (MiTCHELLJONES et al. 1999), bár areájuk átfedi egymást. Ebben az esetben az egyik populáció (a farkas) kiszorítja a másikat (a sakált). Más fajok esetében mindkettó populáció környezeti tényezőkkel szembeni igénye megváltozik, aminek a következményeként niche-ük elkülönül (szegregálódik), és ez lehetôvé teszi a további egymás mellett élést. Koegzisztencia (egymás mellett élés) a különböző fajú, de hasonló ökológiai feltételeket igénylö egyedek, illetve populációik egyazon helyen és időben való együttélését jelenti. A tanulmányban ilyen esetet jelent például a Boronka-melléki Tájvédelmi Körzetben egyidejüleg vizsgált róka, nyuszt és borz. A teljes niche-fedést a térbeli és időbeli elkülönülés, a niche-szegregáció oldja fel. Konkurencia (manapság inkább kompetíció) esetén a nicheátfedés mértéke nő. A niche elkülönülése attól függ, hogy hány dimenzióban térnek el a populációk, tehát nemcsak a táplálkozási kapcsolatok számítanak. Populáció szinten, a korlátozott mértékben rendelkezésre álló forrásokért versengenek a populációk, illetve a populáció egyedei. Az azonos feltételekért való versengésben résztvevő fél a kompetítor. A kompetíció lehet intraspecifikus (fajon belüli) vagy interspecifikus (fajok közötti). Az elóbbi például a territoriális magatartásban nyilvánul meg, míg az utóbbi lehet ragadozó-zsákmány kapcsolat, vagy ragadozó fajok közötti kapcsolat is. 
A továbbiakban a niche-témakörben alkalmazott számítások módszereit ismertetem.

A táplálkozási niche-szélességet Levins képlettel (1968) számítottam:

$$
\mathrm{B}=1 / \Sigma \mathrm{p}^{2}
$$

ahol $\mathrm{B}=\mathrm{a}$ niche-szélesség, értéke 0 -tól $\mathrm{n}$-ig terjed, $\mathrm{n}$ a táplálék taxonok száma, $\mathrm{p}_{\mathrm{i}}=$ az adott táplálék taxon relatív gyakorisága.

A terresztris ragadozók táplálkozási niche-szélességének összehasonlítására standardizálást végeztem. Ennek érdekében Hurlbert által módosított Levins-féle (1968) standardizált niche-szélesség képletét alkalmaztam (KREBS 1989):

$$
B_{A}=(B-1) /(n-1)
$$

ahol $\mathrm{B}_{\mathrm{A}}=$ Levins-féle standardizált niche-szélesség (értéke 0-tól 1-ig terjed); $\mathrm{B}$ = a Levins-képlettel számított niche-szélesség;

n = lehetséges táplálék-források (táplálék-kategóriák) száma.

A százalékos niche-átfedés számítást Renkonen-index felhasználásával végeztem (KREBS 1989):

$$
\mathrm{P}_{\mathrm{jk}}=\left[\Sigma \mathrm{n}\left(\operatorname{minimum} \mathrm{p}_{\mathrm{ij}}, \mathrm{p}_{\mathrm{ik}}\right)\right] \times 100
$$

ahol $\mathrm{P}_{\mathrm{jk}}=$ a százalékos átfedés i és j faj között (értéke 0 és $100 \%$ között terjedhet); $\mathrm{p}_{\mathrm{ij}}=\mathrm{az}$ i-edik táplálék taxon (forrás) részesedése a "j" ragadozó táplálékában,

$p_{i k}=$ az i-edik táplálék taxon részesedése a " $k$ " ragadozó táplálékában. A minimum kifejezés azt jelzi, hogy a kisebb értéket kell figyelembe venni, $\mathrm{n}=$ a táplálék taxonok száma (15 kategória).

A preferencia számításoknál az Ivlev-féle indexet (KREBS 1989) alkalmaztam:

$$
\mathrm{E}_{\mathrm{i}}=\left(\mathrm{r}_{\mathrm{i}}-\mathrm{n}_{\mathrm{i}}\right) /\left(\mathrm{r}_{\mathrm{i}}+\mathrm{n}_{\mathrm{i}}\right)
$$

ahol $\mathrm{E}_{\mathrm{i}}=$ Ivlev-féle preferencia-index (értéke -1-töl +1-ig terjed),

$\mathrm{r}_{\mathrm{i}}=$ adott faj \%-os gyakorisága a táplálékban,

$\mathrm{n}_{\mathrm{i}}=$ adott faj százalékos gyakorisága a környezetben.

A táplálkozási niche számításoknál, valamint a különböző élőhelyeken előforduló terresztris ragadozók táplálék-összetételének összehasonlító vizsgálata során alkalmazott táplálék-kategóriák a következők voltak: 1 - rovarevók és denevérek, 2 - pocokfélék, 3 - egérfélék, 4 - egyéb kisemlősök (pl. pelefélék és meghatározhatatlan rágcsálók), 5 mezeinyúl, 6 - szarvasfélék, 7 - vaddisznó, 8 - ragadozó emlösök, 9 - háziállatok, 10 madarak, 11 - hüllök és kétéltúek, 12 - halak, 13 - gerinctelenek (ízeltlábúak és puhatestủek), 14 - magvak és gyümölcsök, és 15 - egyéb növények (pl. füfélék, levelek).

A vizes élőhelyhez kötődő vidránál alkalmazott táplálék-kategóriák az alábbiak voltak: 1 - emlősök, 2 - madarak, 3 - hüllők és kétéltűek, 4 - halak, 5 - gerinctelenek (ízeltlábúak és puhatestülek) és 6 - növények. 


\section{Egyéb statisztikai módszerek}

$\chi^{2}$-tesztet alkalmaztam a fonói halastó körzetében lezajlott élőhelyi változások értékelésekor, valamint a mezőgazdasági és urbánus környezetben élő nyestek táplálékának összehasonlító vizsgálatakor. Mann-Whitney U-tesztet használtam a különböző terresztris ragadozók táplálékának összehasonlításakor. Egytényezős variancia-analízissel történt az Ivlev-féle preferencia indexek összehasonlítása a halak mérete és preferált élőhelye szerint, kétmintás t-teszttel a niche-szélességi értékek összehasonlítása. Arcussinus transzformációt követően, Pearson korrelációval számoltam a haltáplálék-készlet és vidra haltáplálékának faj szerinti elöfordulási gyakorisága közötti összefüggés szorosságát, valamint a relatív gyakorisági és a biomassza adatok közötti összefüggést. Spearman rangkorrelációt alkalmaztam a haltáplálék-készlet és a vidra haltáplálékának súlykategóriák szerinti összefüggésének vizsgálatára. Pearson-korreláción alapuló hierarchikus cluster-analízissel hasonlítottam össze a különböző fajok, illetve különböző élöhelyeken elöforduló vidra táplálékát. Az adatbázisok kezelését Access (Horváth Gyöző által kidolgozott alaptáblázatban), valamint Excel 7.0 programmal, az adatfeldolgozást SPSS 7.5 (GREEN et al. 1997) statisztikai programmal végeztem.

Az itt felhasznált képleteken, statisztikai módszereken és programokon kívül a lehetőségek bőséges tárháza áll a matematikai megközelítés iránt érdeklődők rendelkezésére (pl. Strauss 1979, SteEl és Torrie 1980, Sasvári 1986, Krebs 1989, DemETER és KoVÁCS 1991, PréCSÉNYI et al. 1995, TótHMÉRÉSZ 1996, ZAR 1996, GREen et al. 1997, stb.). 


\section{A vidra}

A vidra kutatása az 1960-as években kezdődött el táplálkozás-ökológiai és territoriális viselkedés témakörben, melyben Sam Erlinge professzor úttörö szerepet töltött be. A késóbbiekben újabb módszereket, így például rádió-telemetriát is alkalmaztak. Továbbá vizsgálták a vidra szaporodásbiológiáját és az állománycsökkenést kiváltó tényezőket, például öko-toxikológiai szempontból. Napjainkban pedig már elötérbe kerültek a DNSszintű vizsgálatok a vidrakutatási módszerek között.

A halastavakon, víztározókon és folyók mentén élö vidrák táplálék-összetétele viszonylag jól ismert, ezzel kapcsolatban számos összefoglaló munka illetve tanulmány jelent meg (pl. ERLINGE 1967a, 1969, WiSE et al. 1981, CHANIN 1985, MASON és MACDONALD 1986, KRUUK 1995). Tekintve, hogy a vidra táplálékának nagy részét halak alkotják (pl. ERLiNGE 1969, ChANin 1981, WiSE et al. 1981, Mason és MACDONALD 1986, KEMENEs és NechaY 1990, KRUUK 1995, DuLFER és Roche 1998), érthető a halnak, mint fô tápláléknak a központi szerepe a faj elterjedésében, egyedsürúségében és viselkedésében. ERLINGE (1968a) téli nyomszámlálás és értékelés alapján megállapította, hogy téli időszakban a vidrák harmada tart fenn territóriumot, melyek kifejlett, szaporodó hímek, vagy nóstények. A másik harmadrész fiatal példányokból áll, melyek az anyjukkal maradtak a harmadik részt pedig fiatal, de már önálló zsákmányszerzésre képes, kóborló egyedek alkotják. A hímek territóriuma több nőivarú vidráét is átfedheti, de a kölyköt nevelő nőstényeké különálló. Vizsgálata szerint a táplálékbőségtôl függő vidrasürüség a tavakon $0,7-1,0$ egyed $/ \mathrm{km}^{2}$ vízfelületre vetítve, illetve $2-3 \mathrm{~km}$ partszakaszra, vagy $5 \mathrm{~km}$ vízfolyásra jut egy egyed. A territórium határainak fenntartásában az ürülék tölti be a legfontosabb szerepet, melynek szaganyaga és látványa a fajtársak számára fontos jelzés. A ragadozó emlősökre, köztük a vidrára sem jellemző a közvetlen fajon belüli agresszió. A vidra, mint a legtöbb ragadozó emlós tehát szigorúan territórium-tartó faj, létszáma függ a környezet eltartó-képességétől, ezért sem fordulhat elö, hogy adott területen „elszaporodik“. A vidra kölykök más ragadozókkal összehasonlítva sokáig, akár egy éven túl is együtt maradnak anyjukkal (a rókánál és a borznál ez az idő csupán 4 hónap), ezalatt a nőstény nem szaporodik. Ennek következményeként megnő a generációintervallum, ami a faj sérülékenységét jelzi. Ráadásul számos tényezó (illegális vadászat, autóforgalom, táplálékhiány, vízszennyezés) negatívan befolyásolja állományát. A vidra átlagos életkora - egy angliai vizsgálat szerint - mindössze 3 év, a nőstények életük során egy, esetleg két alkalommal kölykeznek és almonként két utódot hoznak világra (KRUUK 1995), miközben a potenciális élettartam 15 év (CHANIN 1985). Lengyelországban, a nagyobb folyókon 1,3-5,0, a közepes folyókon 1,3-1,9, a patakokon 1 vidra jut $10 \mathrm{~km}$ hosszúságú partszakaszra (JEDRZEJEWSKA és JEDRZEJEWSKI 1998). Telemetriás vizsgálatban megállapították, hogy általában napnyugtakor indul vadászútjára és aktivitásának éjszaka két maximuma fígyelhetô meg (KRUUK 1995).

A vidra zsákmányszerzése és egyedsürüsége függ a rendelkezésre álló táplálék-készlettől, a préda fajok évközi állományváltozásától (ERLINGE 1967b, 1968a, KRUUK et al. 1990, 1991, KRUUK és MoORHOUSE 1990). Vizsgálatok szerint (WISE 1980, WISE et al. 1981) haltáplálékának fajösszetétele az évszakok függvényében igen nagy változatossá- 
got mutatott. További tapasztalataik szerint a vidra nem a halak mérete szerint választott. Ennek oka a szerzók feltételezése szerint az egyes halfajok évszakos viselkedésének változásában keresendô, illetve abban, hogy a vidra zsákmányszerzéskor előnyben részesíti a lassan mozgó halakat. Tapasztalatuk szerint a kétéltüeken (27\%) kívül az egyéb zsákmány taxonok elöfordulási gyakorisága alacsony volt. Dél-kelet Lengyelországban végzett vizsgálatában HARNA (1993) az egyes évszakok közötti halfogyasztásban nem talált jelentős eltérést, a halak előfordulása $54 \%$ és $70 \%$ között mozgott. Egy Németországban végzett vizsgálat szerint (GEIDEZIS 1998) a vidra táplálékának döntő részét (87-96\%) alkották halak. Portugáliában, egy vízi erőmú közelében végzett vizsgálat szerint (SALESLUIS et al. 1998) a vidra táplálékának nagy részét (80\%) szintén halak alkották, melyek döntő többsége $(60 \%)$ naphalból állt; a kétéltűek és a rovarok fôként tavasszal, a halak télen, a rákok mennyisége pedig nyáron emelkedett meg jelentősen a táplálék összetételben. Egy Thaiföldön végzett vizsgálat szerint (KANCHANASAKA 1998) az eurázsiai vidra táplálékának viszont csak 37\%-át alkották halak, ezek mellett a legjelentősebb táplálékot a tízlábú rákok $(31 \%)$ jelentették.

A fogyasztott táplálék, különösen a halak mennyiségi- és méretbecslésének kérdése régóta foglalkoztatja a kutatókat. CARSS és PARKINSON (1996) fogságban tartott vidrák táplálkozásának részletes vizsgálata alapján felhívta a figyelmet a táplálék-összetétel vizsgálatok során elkövetett alá- és felülbecsülés problémájára. Zárttéri körülmények között tartott vidrák haltáplálék-preferenciáját vizsgálva ERLINGE (1968b) megállapította, hogy a választás nagyban függ a halkészlettól és a halak megfoghatóságától. Más tanulmányok (WISE 1980, CARss és Elston 1996, CARSS et al. 1998, CARSS és NelsoN 1998, KLosKowsKI et al 2000) a vidraürülékből származó halak méret szerinti besorolásának kérdéskörével foglalkoztak részletesen. Az ürülékben megtalálható halak csigolyamérete és a halak hosszúsága közötti összefüggés számszerüsítése érdekében, néhány halfajra vonatkozóan, a gyakorlatban jól használható regressziós egyenletet dolgoztak ki.

A közép-európai tavakon, folyókon élő vidra éjszaka aktív (nokturnális) és rejtőzködő életmódot folytat, ezért a táplálkozási szokások közvetlen megfigyelése igen nehéz feladat lenne. Így lehetséges terepi kutatási módszert az ürülék-analízis jelent. Ezzel ellentétben, pl. a Shetlandi-szigeteken, ahol a fátlan és bokroktól mentes tengerparton közvetlenül is megfigyelhető a nappal aktív (diurnális) vidra táplálkozási szokása és tanulmányozható a halpreferenciája (KRUUK és MoorHouse 1990, KRUUK 1995). Ezeknek a megfigyeléseknek egy része támpontot jelenthet az édesvizekben élő egyedek viselkedésének magyarázatakor. Vizsgálatok szerint a vidra bundája a tengervízben hamarább átázik, mint az édesvízben, ezért több idő́t kell a tisztogatásával töltenie (KRUUK és BALHARRY 1990). Megfigyelések szerint a tengerparton élő vidra a befolyó édesvizekből nem táplálkozott (legtöbbször erre nem is volt lehetősége), a fenéklakó, lassan mozgó halakat részesítette előnyben (KRUUK és MOORHOUSE 1990); a predáció az eseteknek kevesebb, mint harmadrészében $(27 \%)$ volt sikeres. Főként a partközeli régióban vadászott, ahol a tengerfenékig is lemerülhetett (KRUUK et al. 1990). A közvetlen megfigyelés lehetőséget adott a fogyasztott halak méretének megfigyelésére is. A vidra leggyakrabban a kis méretü (16 cm hosszú) halakat részesítette elónyben, melyeket a felszínen úszva fogyasztott el. A nagyobb méretú halakat húzta csak a partra. Ilyen esetek a kölykök nevelése idején, illetve télen fordultak elö, amikor energetikai szempontból nem kedvező a hideg vízben hosszú időt tölteni. A vidra napi táplálékfogyasztása a testsúly 15\%-ára tehető (KRUUK 1995). KRUUK et al. (1991) vizsgálata szerint a tengerparton élő vidra szaporodása szezonális jellegü, amit a préda fajok évszakos állománysürüség változása szinkronizál. E tekintetben eltérés mutatkozik az egész évben viszonylag gazdag táplálék-forrással rendelkező édesvizeken élő közép-európai vidrától. Ennek eredményeként nálunk egész évben szaporodhat, bár leggyakrabban februárban következik be a "füttyögetés", azaz a nászidőszak. 
A Kárpát-medencei állomány jelenleg még stabil, megóvása a faj fennmaradásának egyik nagyon fontos feltétele lehet. Magyarországon a vidra 1974 óta természetvédelmi oltalom alatt áll. Feltételezhetốn a védelemnek és a nagy kiterjedésú mesterséges halastórendszerek kialakításának köszönhetően nőtt a vidrapopuláció. Az utóbbi években, a mezőgazdasági területek privatizációjával a halastavak döntô része is magánkézbe került. A fokozottan védett vidrával együtt jelentkezik annak kártétele és felmerül a vélt, vagy valós kár megtérítésének igénye is (TANKó és TASSI 1978, GERA 2001). A tényleges kár viszont nehezen állapítható meg. Kártérítési pénzalap, illetve kompenzációs közgazdasági kedvezmények pedig máig sincsenek annak ellenére, hogy a Természetvédelmi Törvény erre lehetôséget ad. Egy közép-európai (osztrák, kelet-német tartományi, cseh és magyar) összehasonlítás szerint (KRANZ 2000) a magyar halastó tulajdonosoknak legnagyobb kárt (65\%-ban) a kormorán okozza, majd második helyen szerepel a vidra $(20 \%)$, de ezzel szinte megegyező az illegális horgászat $(15 \%)$. Ez utóbbi tényezó nálunk a legmagasabb arányú. A többi, a vizsgálatban szereplő országban a vidra károkozását a hazainál nagyobbra becsülték (40-88\%).

Már a védetté nyilvánítást követően felmerült a vidra táplálkozási szokásainak és az élőhely kapcsolatának kutatása iránti igény (TANKó és TASSI 1978). Miért van erre szükség? Mert a vidra táplálék-összetételének, és ezen keresztül szokásainak ismerete segítséget jelenthet kártételének mérséklésében. Magyarországon a vidra táplálkozás-ökológiai vizsgálata azért kezdődött meg, mert a külföldi eredmények egy részének a hazai ökológiai feltételek melletti adaptálása nehézkesnek tünt. Például számos vizsgált halfaj nálunk nem él, vagy ritkaságnak számít, pl. lazac, pisztrángok, ugyanakkor több fontos hazai faj szerepét egyáltalán nem vizsgálták a táplálék-összetételben. További lényeges szempont, hogy a hazai vidraállomány nemzetközi viszonylatban is számottevô.

Magyarországon elsőként KEMENEs (1988) publikált adatokat a vidra táplálék-összetételéről. A szerző a vidra táplálékában összesen kb. 20\%-ban talált puhatestűeket, ízeltlábúakat, kistestü madarakat, kisemlősöket, növényeket, és $80 \%$-ban halakat. Vizsgálata szerint a gazdaságilag jelentôs halak aránya még tógazdasági területen sem haladta meg a 40\%-ot. További vizsgálatokban (KEMENES és NECHAY 1990) öt, egymástól lényegesen eltérő magyarországi területen: a Balatonon, a Kis-Balatonon, az ócsai védett tőzeglápon, a veresegyházi horgásztavon és a somogy fajszi horgásztavon tanulmányozták a vidra téli és tavaszi táplálék-összetételét. Vizsgálatuk szerint élóhelytől függetlenül a hal volt a vidra domináns tápláléka (67-91\%), legalacsonyabb értéket Somogyfajszon, a legmagasabbat Veresegyházán tapasztalták. Másodlagosan fontos táplálékot képeztek a rovarok $(4,0-28,1 \%)$ a Balatonon, a Kis-Balatonon, Ócsán és Somogyfajszon, valamint a puhatestűek (5,6\%) Veresegyházán. A kétéltủek (3,3\%) csak a Balatonon, az emlősök $(5,5 \%)$ és a madarak $(4,1 \%)$ a Kis-Balatonon voltak jelentősek a táplálékban. A szerzők a haltáplálékot gazdasági szempont alapján (káros, közömbös és haszonhal) csoportosították és értékelték. A vizsgált területek sokféleségéből adódóan azt tapasztalták, hogy egyes területeken a vidra táplálékában a gazdaságilag közömbös és káros halak domináltak, míg máshol a gazdaságilag jelentős fajok fordultak elő nagyobb részesedésben. Megállapításuk szerint a vidra generalista a haltáplálékkal szemben, nem részesít előnyben egyes halfajokat. Ez alapján a szerzők a halgazdaságok számára azt javasolták, hogy célszerủ a természetes halállományt is fenntartani, mert a járulékos halak a vidra haltáplálékát képezik. NAGY (1999) a Balatonon és a Kis-Balatonon élő vidra későbbi tanulmányozása során a KEMENES és NECHAY (1993) vizsgálatához hasonló eredményt kapott.

A vidra elterjedési okainak felderítése szempontjából fontos KEMENEs (1993), valamint KEMENES és DEMETER (1994) kutatása. Vizsgálatuk szerint a vidra meglepóen toleráns az emberi tevékenységből adódó zavarással szemben (városok közelsége, földmúvelés). Ezzel ellentétben kimondottan érzékeny a part menti vegetáció eltávolítására és a vízmélység csökkenésére, valamint nem kedveli a meredek partoldalt. 
Az eddigi, hazai elterjedésre vonatkozó felmérések (TANKó és TASsi 1978, KEMENES 1993, SZEMETHY és HelTAi 1996, Gera 2001, HeLTAI 2002), továbbá élóhelyi vizsgálatok (KEMENES és DEMETER 1994, 1995), valamint a korábbi (KEMENES és NECHAY 1990, KEMENES 1993, NAGY 1999) és jelen tanulmányban szereplő táplálkozás-ökológiai kutatások alapján körvonalazódik a vidra jelentósége és szerepe halastavainkon és más vizes élöhelyeken. Mindezek egy esetleges vidravédelmi stratégia és a kármérséklö gyakorlat kialakításakor adhatnak segítséget.

\section{A vidra tápláléka és halpreferenciája halastavakon}

\section{A vidra táplálék-összetétele}

Saját vizsgálataim szerint a vidra táplálékában területtôl, évszaktól és évtől függetlenül általában a hal dominált, aránya a Fonói halastó körzetében (FHTk) 41 és 81\%, a Boronka-melléki Tájvédelmi Körzetben (BmTK) 67 és $91 \%$ között alakult (19. ábra, 3. melléklet). Azokban az időszakokban, mikor haltermelés folyt a tavakon, viszonylag alacsony arányban fogyasztott a másodlagosan fontos táplálék-forrásokból, például a kétéltüekból.

A FHTk-ben, a II. mintavételi időszakban $(3 .+4$. év) a vidra számára kedvezőtlen élőhelyi feltételek mellett az egyébként másodlagosan fontos kétéltűek (főként békák) váltak elsődlegesen fontos táplálékká. Ez elsösorban a vidra tavaszi fö szaporodási időszakában volt jellemző, de kiemelkedóen magas volt a kétéltűek fogyasztása nyáron is. A vizsgált területeken a kétéltü táplálék-forrásban a barna varangy mellett, a FHTk-ben a tavi béka, a BmTK-ben az erdei béka válhatott nagyobb számban prédaállattá. Ezeken kívül mindkét területen jelentős számban zsákmányolhatott kecskebékát, kisebb számban mocsári békát, zöld levelibékát, vöröshasú unkát, tarajos götét és a pettyes götét is. A BmTK-ben a fenti fajokon kívül megtaláltuk a zöld varangyot és kis egyedszámban a barna ásóbékát, valamint a kis tavibékát is az ürülékmaradványok között.

A FHTk-ben a II. időszakban a kétéltúeken kívül a vidra számottevő mértékben fogyasztott gerincteleneket is. A legjelentósebb faj a sárgaszegélyű csíkbogár volt (19. ábra, 3. melléklet). A gerinctelenekböl álló táplálékában nemcsak vízhez kötődő fajok, pl. szitakötők, tízlábú rákok, bolharákok, karimás tányércsiga, hanem a tavakat körülvevô erdőkben élő szárazföldi fajok is szerepeltek, pl. kékfutrinka, májusi cserebogár. Az öszszes többi táplálékcsoport kis jelentôségü volt (19. ábra, 3. melléklet) a három fô kategória (halak, kétéltủek+hüllók és gerinctelenek) mellett.

A kisemlősök közül a FHTk-ben rovarevőket, mezei nyulat, vándorpatkányt, pézsmapockot, vízipockot, mezei pockot, erdei pockot, valamint a BmTK-ben erdei egereket és erdei pockot evett. Öz fogyasztása csak egy esetben fordult elő $\left(\mathrm{FHTk}_{\mathrm{III}}\right)$, amikor valószínúleg elhullott állatból táplálkozott a vidra.

A vidra nyáron (különösen a $\mathrm{FHTk}_{\mathrm{I}}$ esetében) fogyasztotta a legtöbb madarat. A madártáplálékot zömében kistestü énekesmadarak alkották, de ezek mellett a FHTk-ben fácánt és szárcsát, a BmTK-ben a szárcsa mellett récefélét is evett.

A növényi táplálékot zömében vízhez kötődő fajok alkották, pl. gyékényfélék, sásfélék és békalencse. Előfordulási arányuk különösen a FHTk-ben, az I. időszakban volt magas, a BmTK-ben viszont alacsony szinten mozgott.

A felmérések alapján megállapítható, hogy a halastavakon élő vidra elsődlegesen fontos (domináns) táplálékát más vizsgálatokhoz hasonlóan halak képezték. Az élóhelyi változások a vidra táplálékforrását jelentôs mértékben érintették. A halgazdálkodás elmaradásának, a halsûrűség drasztikus csökkenésének és a növényzetben bekövetkezett 


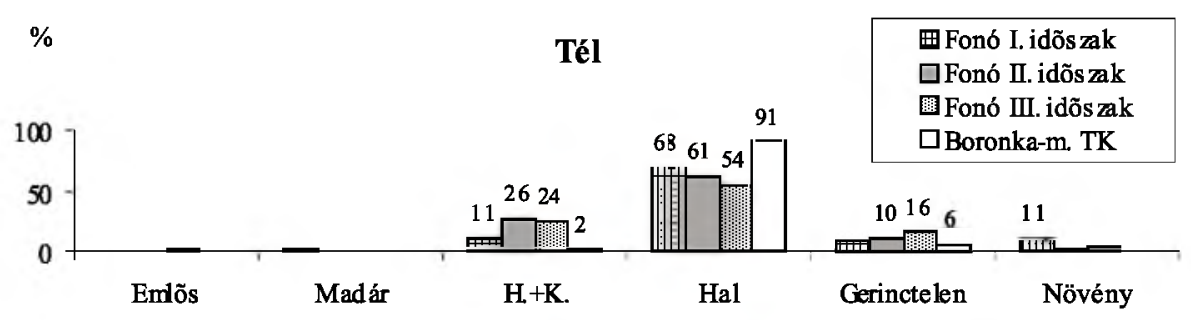

$\%$

Tavasz

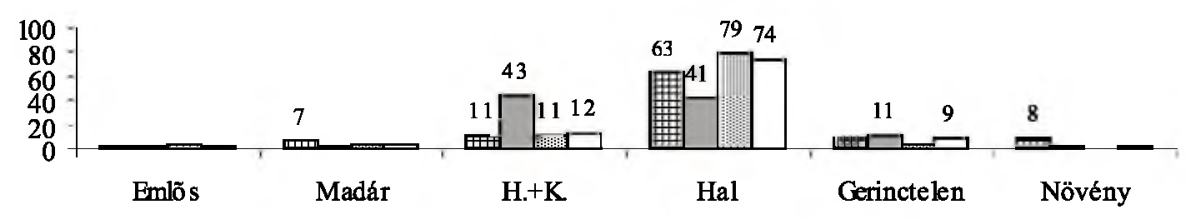

$\%$

Nyár
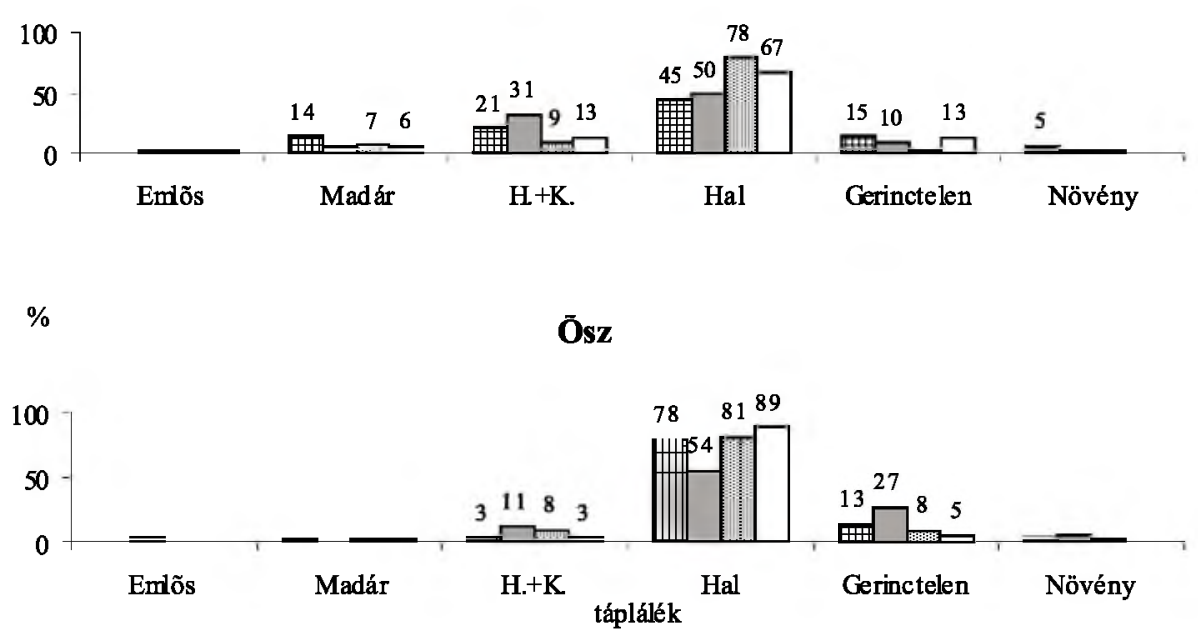

19. ábra: A vidra évszakonkénti táplálék-összetétele a fonói halastavon és a Boronka-melléki Tájvédelmi Körzetben

Megjegyzés: H.+K. = hüllő és kétéltú együtt 
kedvezőtlen változások hatására a vidrák a rendelkezésre álló, egyébként másodlagosan fontos táplálékforrásból fơként kétéltüeket, kisebb részben vízi rovarokat fogyasztottak. Eközben a hal - időszakosan - másodlagosan fontos táplálékká vált. A vizsgált területeken történő halgazdálkodásnál tapasztaltakhoz hasonlóan, egy skóciai vizsgálatban (WEBER 1990) télen és koratavasszal viszonylag nagy arányú kétéltủ fogyasztást tapasztalt, mely szoros korrelációban $(\mathrm{r}=0,86)$ állt a rendelkezésre álló táplálék csoport sủrúségével. Más élőhelyen viszont a vidra vízimadarakat és mezei nyulat fogyasztott jelentős mértékben (WISE et al. 1981). Külföldön végzett vizsgálatban a madarakat nyáron, az emlősöket egész évben másodlagosan fontos tápláléknak találták (SKARÉN 1993). Finnországi (SULKAVA 1996), valamint lengyelországi (HARNA 1993) megfigyelések szerint télen a vidra a befagyott tavakat övező területeken, az iszapban telelő kétéltúeket kereste meg és fogyasztotta előszeretettel. Az eredmények azt jelzik, hogy a halastavak körüli vizes élöhelyek (sásos, nádas, bokorfüzes, erdöfolt) a vidra számára lényeges táplálékszerző területnek minősülnek (KEMENEs és DEMETER 1994), hiszen a vizsgálatok szerint fontos vidra táplálék-forrásokat rejtenek. Nem célszerü a tavak körzetében ezek megszüntetésére törekedni (nemcsak a vidra miatt). A vidrák halastavi gazdálkodás esetén is bejárják ezeket az élőhelyeket, ezáltal is mérséklődik a halállományban okozott kár.

\section{A vidra haltápláléka és a halkészlet közötti összefüggés}

Az eddig ismertetett eredmények elsősorban ökológiai és természetvédelmi szempontból lehetnek érdekesek. A halpreferencia vizsgálat viszont halgazdálkodási és kármegelőzési - de kapcsolódóan természetvédelmi - szempontból is lényeges.

Az alábbiakban szereplö, a haltáplálék-készletre vonatkozó kétféle számítási mód szükségessége és alkalmazása magyarázatra szorul. A lehalászási eredmény alapján történt a halfajok, illetve azon belül a különböző korosztályok elöfordulási gyakoriságának meghatározása. Ezt az egyedszám alapján kapott adatsort leggyakrabban nem követi a biomassza számításon alapuló adatsor. Ugyanis egy-egy halfaj nagy egyedszámban fordulhat eló, miközben biomasszája kicsi és fordítva. A korreláció-számításhoz a halkészlet százalékos relatív előfordulási gyakorisági adatai szükségesek, hiszen a vidra táplálék-összetételének vizsgálatakor ezzel megegyező számításmódú adatsort kapunk. A vidra halpreferenciájának értelmezéséhez viszont a biomassza adatok is fontosak. A különböző években a haltáplálék-készlet eltért biomassza- és előfordulási gyakorisági számítás alapján is, ezért az egymást követô éveket külön-külön is értékelni kellett.

A Fonói tavon az elsố év lehalászási eredménye szerint (4. melléklet) a halbiomasszában a ponty $(85 \%)$ dominált, emellett jelentős volt a telepített fogassülló és a harcsa. Egyedszám alapján leggyakoribb a naphal volt $(36,5 \%)$, de hasonló gyakorisággal fordult elő a ponty $(34 \%)$, valamint számottevő volt még a fogassüllő ( $28 \%$ ) részaránya is. A vidra haltáplálékában, a táplálék-készletben legnagyobb gyakorisággal előforduló ponty $(33 \%)$, valamint a naphal $(25 \%)$ szerepelt, ugyanakkor süllö nem fordult elö. A tó haltáplálék-készlete és a vidra haltápláléka között fennálló korrelációs kapcsolat közepesen szoros volt $\left[\mathrm{r}_{\mathrm{P}}=+0,56, \mathrm{P}<0,05\right]$.

A második évben (4. melléklet) a haltelepítési szerkezet - a többi évtól eltéróen - fehér busa dominanciájú volt. A lehalászáskor mért biomasszában a fehér busa volt meghatározó $(86 \%)$, ugyanakkor legnagyobb egyedszámban a kínai razbóra fordult eló (56,5\%). A vidra legfontosabb táplálékát is a razbóra (56\%) és a naphal (19\%) képezte, ugyanakkor a készletben való előfordulási aránynál lényegesen ritkábban fogyasztott fehér busát $(1,3 \%)$ és pontyot $(5 \%)$. A tó haltáplálék készlete és a vidra haltápláléka között fennálló korreláció szoros volt $\left[\mathrm{r}_{\mathrm{P}}=+0,87, \mathrm{P}<0,001\right]$.

A harmadik és negyedik évben (4. és 5, melléklet) a tó halasítása elmaradt. A vidra táplálékában, több hónapban is más területrốl származó halfajok példányai fordultak elố, 


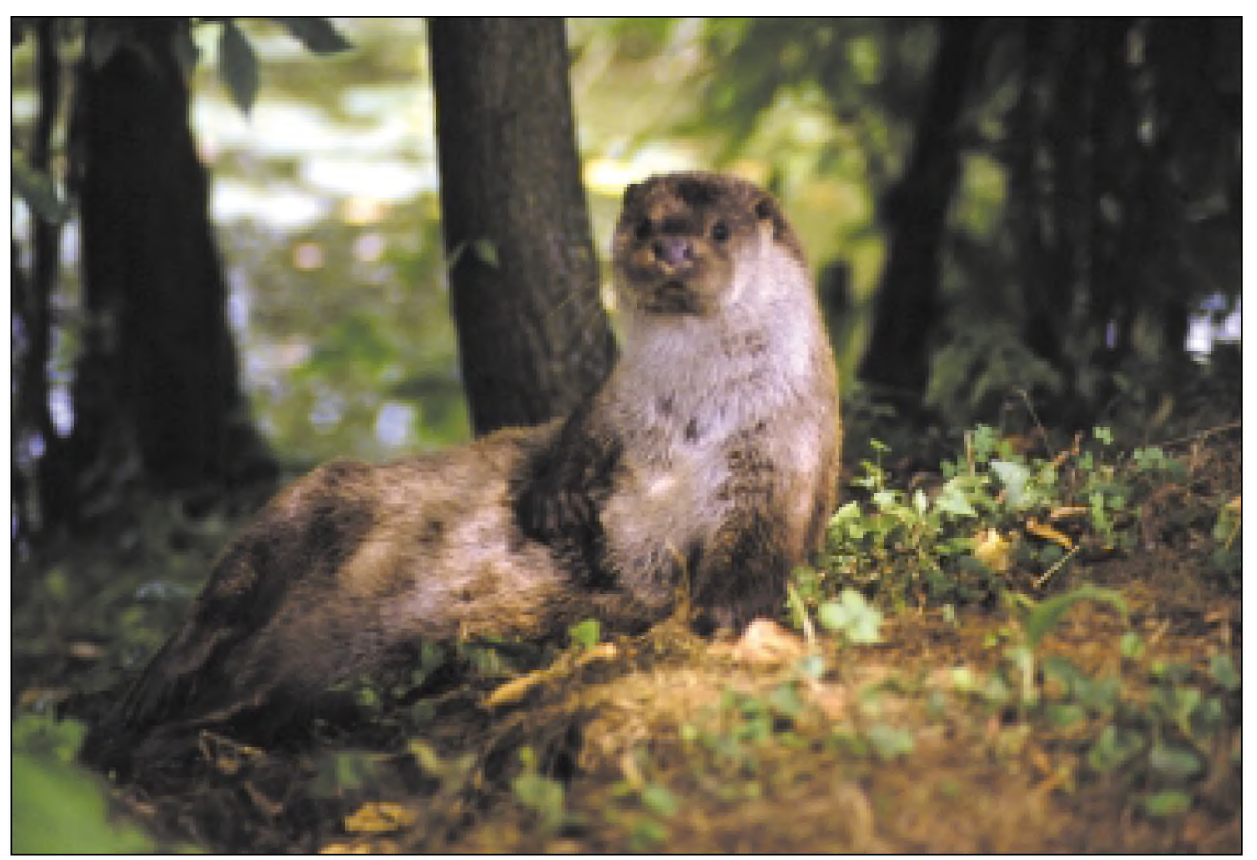

20. ábra: Vidra (Lutra lutra)

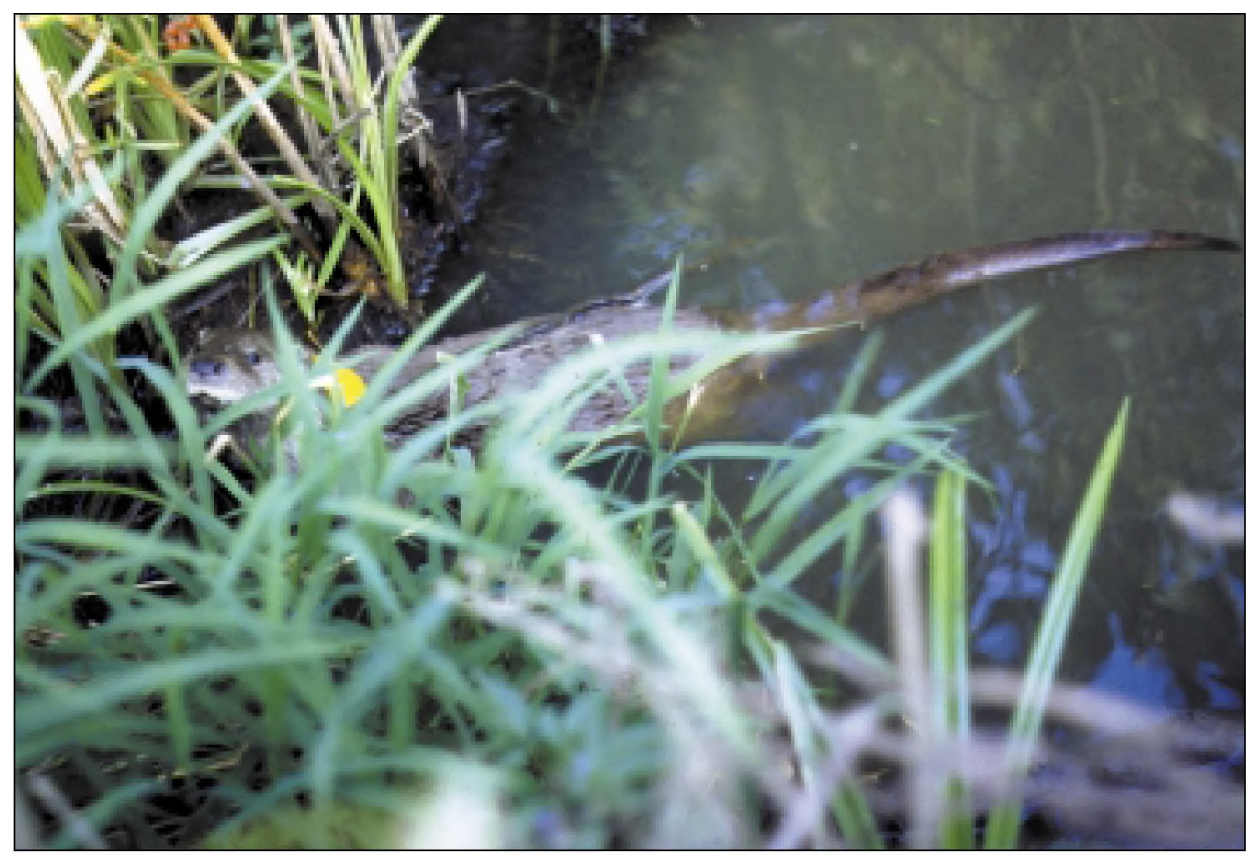

21. ábra: Legtöbbször csak ennyi látható a vidrából 


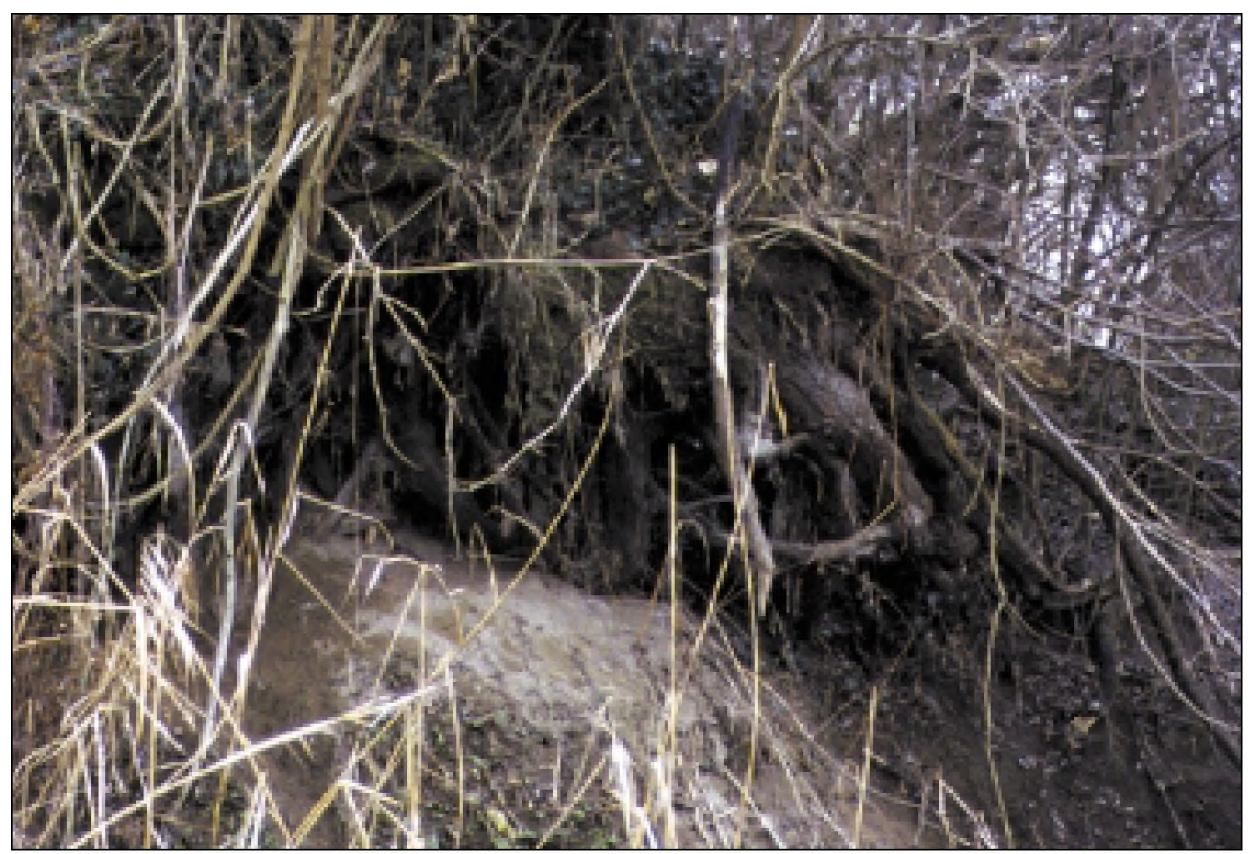

22. ábra: A vidravár kijárata legfeljebb alacsony vízállásnál kerül elő

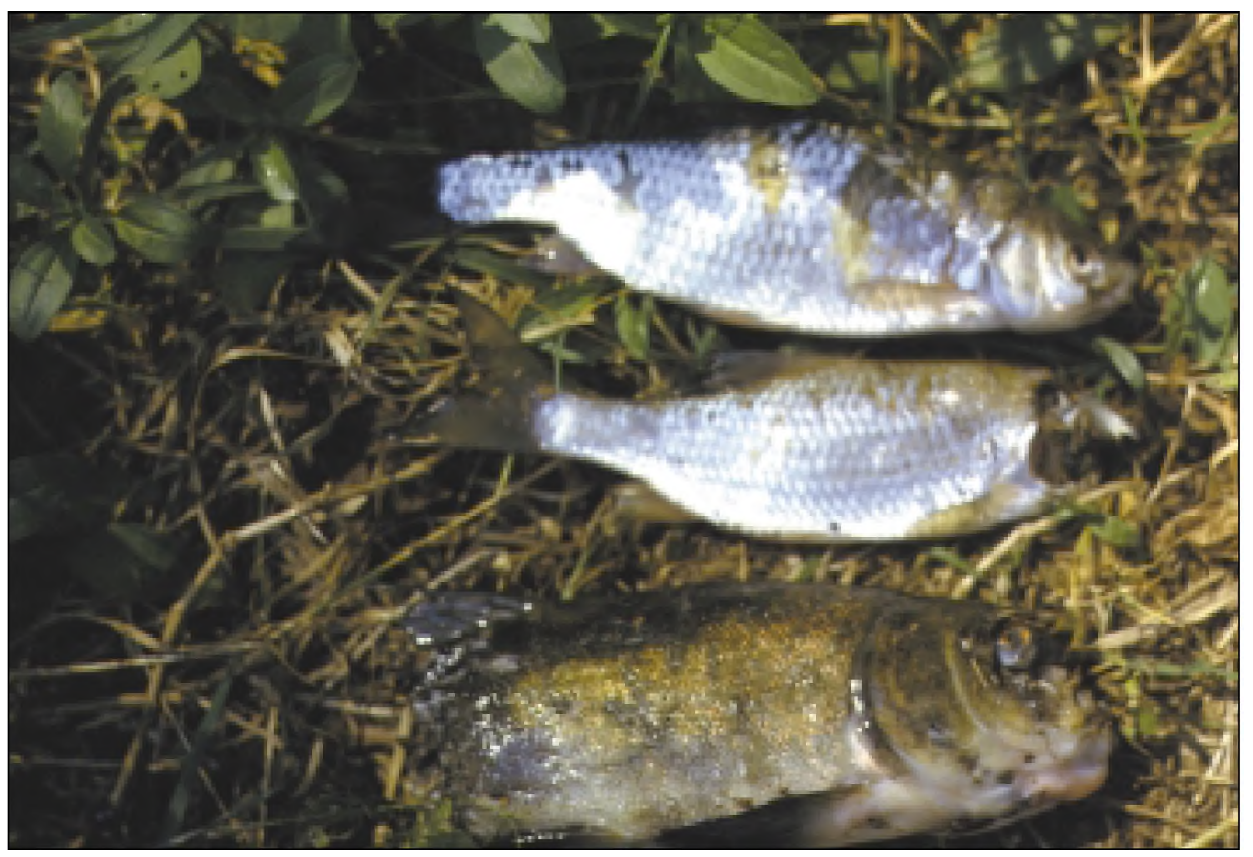

23. ábra: Vidra által megrágott halak, jellegzetes harapásnyomokkal 
pl. február, június, július, augusztus, szeptember, október hónapokban. A vidra területhúségét jelzi, hogy nem hagyta el véglegesen a halban szegény területet. Ehelyett táplálékspektruma szélesedett. A gyüjtött mintaszám viszont lényegesen elmaradt a többi időszaktól, feltehetően csökkent az egyedsürüség és elmaradt a kölyöknevelés is. A legfontosabb haltáplálékot a második évhez hasonlóan a legnagyobb egyedszámban jelen levő razbóra jelentette $(64,5$, illetve $52,5 \%)$. A haltáplálék-készlet és a vidra haltáplálékának előfordulás szerinti relatív gyakorisága között szoros korrelációs kapcsolat állt fenn $\left[\mathrm{r}_{\mathrm{P}}=+0,93, \mathrm{P}<0,001\right.$, illetve $\left.\mathrm{r}_{\mathrm{P}}=+0,79, \mathrm{P}<0,05\right]$.

Az ötödik évben, a halastó rekonstrukciós munkáit követően újból megindult a haltermelés. Egyenlö biomassza számítás szerinti arányban (35-35\%) halászták le a pontyot és a fehér busát, az amúr pedig 17,5\%-kal szerepelt (5. melléklet). A haltáplálék-készletben leggyakoribb ponty (43\%) mellett, jelentős volt a kínai razbóra (41\%) is. A tókezelési munkák során ebben az évben nem sikerült megvalósítani a gyomhal mentesítést, mert a tó nem volt télen szárazra állítva, valamint nem történt meg a megfelelő ragadozóhal telepítés sem. Ilyen esetben - a gyomhalak nagyarányú jelenléte miatt - általában a gazdaságilag jelentős halak hozama is kedvezötlenebbül alakul. Ebben az évben a vidra leggyakrabban razbórát (28\%) evett. A ponty 17\%-ban, a fehér busa pedig 3\%-ban fordult elő haltáplálékában. A haltáplálék-készlet és a vidra haltápláléka között alacsony, nem szignifikáns korrelációs kapcsolat állt fenn $\left[\mathrm{r}_{\mathrm{P}}=0,36, \mathrm{NS}\right]$.

A hatodik évben ponty (47\%) dominált a hal biomasszában, emellett a fehér busa (35\%) volt jelentős (5. melléklet). A halastó halkészletében a ponty (45\%) mellett a razbóra (30\%) volt a leggyakrabban előforduló faj. A gyomhal mentesítés ebben az évben sem volt eredményes. A vidra haltáplálékában legnagyobb arányban razbóra (53\%), valamint ponty (31\%) szerepelt. A haltáplálék készlet és a vidra haltáplálékának előfordulás szerinti relatív gyakorisága között szoros korrelációs kapcsolat állt fenn $\left[\mathbf{r}_{\mathrm{P}}=\right.$ $+0,81, \mathrm{P}<0,001]$.

A Boronka-melléki Tájvédelmi Körzetben, az első vizsgálati évben az ezüstkárász dominált a hal biomasszában (47\%), emellett a ponty $(25,5 \%)$ és a csuka $(26 \%)$ volt jelentôs. A haltáplálék-készletben, az ezüstkárász (76\%) volt a leggyakoribb faj, míg a csuka $(11 \%)$ és a ponty (5\%) elófordulási aránya lényegesen kisebb volt (6. melléklet). A vidra haltáplálékában is az ezüstkárász dominált (63\%), de nem a tavakban leggyakoribb 100 g alatti méretủ, hanem a 100-500 g közötti tartományba tartozó egyedek. Emiatt a haltáplálék készlet és a vidra haltápláléka között gyenge korrelációs kapcsolat állt fenn $\left[\mathrm{r}_{\mathrm{P}}=0,02, \mathrm{NS}\right]$.

A második vizsgálati évben a halbiomasszában a ponty $(64 \%)$ dominált, emellett az ezüstkárász (18\%) biomassza szerinti aránya volt számottevő. Ezzel szemben a haltáplálék-készletben a sügér (43\%) mellett az ezüstkárász (29\%) és a ponty (13\%) volt megtalálható nagyobb gyakoriságban (6. melléklet). A vidra haltáplálékában az ezüstkárász (43\%) fordult elő leggyakrabban, második helyen a razbóra (21\%) szerepelt. A haltáplálék-készlet és a vidra haltápláléka között gyenge korrelációs kapcsolat állt fenn $\left[\mathbf{r}_{\mathrm{P}}=\right.$ 0,33 , NS]. Ennek valószínú oka az, hogy nem a legnagyobb gyakorisággal előforduló, 50-100 g-os sügért fogyasztotta a vidra, hanem a számára kedvezőbben zsákmányolható $100-500$ g-os ezüstkárászt.

\section{A halastavon élö vidra halpreferenciája}

A Fonói tavon az 5. évben, valamint a Boronka-melléki Tájvédelmi Körzetben tapasztalt alacsony, nem szignifikáns korrelációs együtthatók felhívták a figyelmet arra, hogy a vidra haltáplálék választását nem feltétlenül a halfaj határozta meg, hanem azt más tényezők is jelentősen befolyásolták, így például a halak mérete és legjellemzőbb előfordulási régiója. 
A haltáplálék-készlet és a vidra haltáplálékának méret szerinti megoszlása között, a Fonói tavon, az 1-6 év összesített adatai alapján szoros kapcsolatot $\left[\mathrm{r}_{\mathrm{S}}=0,70, \mathrm{P}<0,001\right]$, a Boronka-melléki Tájvédelmi Körzetben a két év összesített adatai alapján közepesen szoros kapcsolatot $\left[\mathrm{r}_{\mathrm{S}}=0,63, \mathrm{p}=0,06\right]$ tapasztaltam. A fennálló kapcsolatok szorossága alapján történt a részletes preferencia-vizsgálat.

A preferencia adatok alapján látható, hogy a vidra a nagy súlyú (1000 g feletti), általában fenék közeli és nyílt vízi régióban élő halakat fajtól függetlenül nem részesítette előnyben, vagyis nem kereste a vadászútja során (4. táblázat). Félintenzív jellegű haltermelésben (FHTk) a 100-500 g-os amúrt, az 500 g alatti compót nem vadászta, a 100-500 g-os pontyot a FHTk-ben nem, az alacsony halsürüséggel jellemezhetó BmTK-ben viszont előnyben részesítette (4. táblázat). Preferálta továbbá az 500 g és 1000 g közötti mérettartományba esố pontyot, és a partközelben élő 100-500 g-os ezüstkárászt. A parti zónában élö $100-500 \mathrm{~g}$-os csukát és a $100 \mathrm{~g}$ alatti sügért általában preferálta, azaz a halkészletben való előfordulási gyakoriságuknál nagyobb arányban fogyasztotta. Figyelemre méltó, hogy bizonyos kisméretú ( $50 \mathrm{~g}$ alatti) halfajokat, így a nagy gyakorisággal elöforduló, part menti és nyíltvízi régióban élö razbórát és a parti zónában élố naphalat az előfordulásuk gyakoriságával megegyező mértékben, vagy nagyobb arányban fogyasztotta. A haltermelési időszakok kivételével $\left(\mathrm{FHTk}_{\mathrm{II}}\right)$, a tápvízben honos halfajok mellett a vízfenéken élö, iszaplakó csíkféléket is előnyben részesítette. A sekély, tiszta vizekben előforduló 100-150 g-os süllőt, valamint a szélhajtó küszt pedig az egyes években eltérô mértékben preferálta. A FHTk-ben, a 6. évben tapasztalt jelentős süllőfogyasztásban közrejátszhatott, hogy a haltáplálék-készletben a halak döntố többsége 500 grammnál kisebb súlyú volt. Ugyanakkor a vidra számára egyébként legkedvezőbb 500-1000 g-os halak alacsony arányban fordultak eló (4. táblázat), ezért fogyasztott nagy arányban például süllőt is.

Az évenkénti adatok összevonása és értékelése alapján megállapítható (24. ábra), hogy a halastavon élő vidra a nagy súlyú (1000 g feletti) halakat mellózi vadászata során. Szignifikánsan $(\mathrm{P}<0,01)$ preferálta viszont az $500 \mathrm{~g}$ és $1000 \mathrm{~g}$ közötti mérettartományba eső egyedeket. Nem volt megfigyelhető egyértelmü preferencia az $500 \mathrm{~g}$ alatti mérettartományra. Vagyis a vidra a fél kilogramm súly alatti halakat a víztérben való előfordulásuk gyakorisága körüli arányban fogyasztotta. Az eredmények értelmezésekor lényeges, hogy a területeken halteleltető tavak nem múkködtek.

A halak víztérben való jellemző elófordulási régiójának elemzése alapján (24. ábra) megállapítható, hogy a halastavakban előforduló vidra szignifikánsan $(\mathrm{P}<0,01)$ mellőzte a nyíltvízi régióban élő halakat. Kismértékben mellözte a vízfenék közelében, kismértékben preferálta a part közelében és jelentősen preferálta a vízinövényekkel benőtt régióban élő halakat.

Következtetésként megállapítható, hogy a haltáplálék-készlet és a vidra haltáplálékának méret (súly) szerinti eloszlása nagymértékben hasonló. Ez felhívja a figyelmet arra, hogy a vidra a rendelkezésre álló halkészletből az egyes méretkategóriák előfordulási gyakorisága szerint választ haltáplálékot. Tehát nem a faj, hanem a méret a meghatározóbb. Azonban ha a haltáplálék-készletben mindössze egy, vagy két súlykategóriába esik a halak döntő többsége (4-6. melléklet), akkor a vidra akár a számára nem kedvezö (valószínủleg kevésbé gazdaságosan zsákmányolható) mérettartományba eső halakból is többet fogyaszthat.

A többféle korosztállyal jelen levő halfajoknál, így pl. a hazai halastavi termelésben legjelentősebb ponty esetében a fajra általánosan vonatkozó Ivlev-féle preferencia index $\left(\mathrm{E}_{\mathrm{i}}\right) 0$ körüli értéke nem ad kelló információt a tényleges preferencia mértékéröl. Hasonló megállapítás érvényes az amúrra, csukára és ezüstkárászra is. Ezért a vizsgálatokat nemcsak fajonként, hanem korosztályonként (ill. súlykategóriánként) is elvégezve, lényeges eltérések tapasztalhatók, melynek gazdasági jelentősége van. A halastavon éló 


\section{4. táblázat : A halastavon élő vidra halpreferenciája}

Megjegyzések: halak régiónkénti preferált előfordulása : $\mathrm{F}=$ vízfenéki, $\mathrm{N}=$ nyíltvízi, $\mathrm{V}=$ vízinövényekkel (hínártársulásokkal) benött, $\mathrm{P}=$ partmenti régió; súlykat.= halak súlykategóriái: 1: $50 \mathrm{~g}$ alatt, 2: $50-100 \mathrm{~g}, 3$ : $100-500 \mathrm{~g}, 4: 500-1000 \mathrm{~g}, 5: 1000 \mathrm{~g}$ felett.

Ivlev-féle preferencia index (terjedelem: -1-től +1-ig): "+" preferálás /elônyben részesítés / keresés, "-" mellőzés / elkerülés.

\begin{tabular}{|c|c|c|c|c|c|c|c|c|c|c|c|}
\hline \multirow{5}{*}{ Haltajok } & \multirow{2}{*}{\multicolumn{2}{|c|}{ Hal }} & \multicolumn{9}{|l|}{ Terület } \\
\hline & & & \multicolumn{6}{|c|}{ Fonói halastó } & \multicolumn{2}{|c|}{ Botonka-m. TK. } & \multirow{3}{*}{$\begin{array}{l}\text { Átlagos } \\
\text { preferencia }\end{array}$} \\
\hline & \multirow{3}{*}{$\begin{array}{l}\text { preferált } \\
\text { elófordula }\end{array}$} & \multirow{3}{*}{ súlykat. } & Év & & & & & & & & \\
\hline & & & 1 & 2 & 3 & 4 & 5 & 6 & 1 & 2 & \\
\hline & & & \multicolumn{6}{|c|}{ Ivlev-féle preferencia index a halakk súlya alapján } & & & \\
\hline Ponty Cyprinus carpio osszesen & & 3.-5. & 0,02 & 0,38 & & & $-0,45$ & 0,17 & $-0,15$ & $-0,37$ & $-0,13$ \\
\hline Cyprinus carpio & $\mathbf{F}, \mathbf{P}, \mathrm{V}$ & 5 & $-1,00$ & & & & & & $-0,41$ & $-0,81$ & $-0,74$ \\
\hline Cyprinus carpio & $\mathbf{F}, \mathbf{P}, \mathrm{V}$ & 4 & 0,52 & 0,38 & & & 1,00 & 0,98 & 0,76 & 0,70 & $+0,72$ \\
\hline Cyprinus carpio & $\mathbf{F}, \mathbf{P}, \mathrm{V}$ & 3 & & & & & $-0,92$ & $-0,19$ & $-0,29$ & 0,98 & $-0,11$ \\
\hline Feherbusa Hypophthatamichtis molitrix & N & 5 & & $-0,80$ & & & 0,10 & $-0,74$ & & & $-0,48$ \\
\hline Amút Clenopharingodon idella összesen & & 4.-5. & & & & & & & & 0,08 & $+0,08$ \\
\hline Ctenopharingodon idella & $\mathbf{P}, \mathbf{Y} F, \mathbb{N}$ & 5 & & & & & & & & $-0,03$ & $-0,03$ \\
\hline Ctenopharingodon idella & $\mathbf{P}, \mathbf{V}, \mathrm{F}, \mathrm{N}$ & 4 & & & & & & & & 0,24 & $+\$ 24$ \\
\hline Ctenopharingoton idella & $\mathrm{P}, \mathrm{Y}, \mathrm{F}, \mathrm{N}$ & 3 & & & & & $-0,24$ & $-0,02$ & & & $-0,13$ \\
\hline Sülló Stizostedion iucioperca & $\mathrm{N}, \mathbf{F},(\mathbb{P})$ & 3 & $-1,00$ & $-0,41$ & & & 0 & 0,82 & & & $-0,15$ \\
\hline Csuka Esox lucius összesen & & 2.4 & & & & & & & $-0,27$ & $-0,31$ & $-0,29$ \\
\hline Esox hucius & $\mathrm{P}, \mathrm{Y}, \mathrm{N}$ & 4 & & & & & & & $-1,00$ & $-1,00$ & $-1,00$ \\
\hline Esox lucius & $\mathbf{P}, \mathbf{Y}$. & 3 & & & & & 0,90 & 0,95 & 0,75 & $-0,51$ & $+0,52$ \\
\hline Esox iucius & $\mathrm{P}, \mathrm{Y}$ & 2 & & & & & & & 0,99 & 0,02 & $-0,49$ \\
\hline Harcsa Siturus glanis & $\mathbf{F}, \mathbf{P}$ & 5 & $-1,00$ & & & & $-0,50$ & $-1,00$ & & & $-0,83$ \\
\hline Ezüstkárász Carassius auratus gibelio összesen & & $2-4$. & & & & & & & $-0,09$ & 0,20 & $+0,05$ \\
\hline Carassius catratus gibelio & $\mathbf{F}, \mathbf{P}, \mathrm{V}$ & 4 & & & & & & & $-0,77$ & $-0,56$ & $-0,66$ \\
\hline Carassius cauratus gibelio & $\mathbf{P}, \mathbf{V}, \mathrm{F}$ & 3 & 0,95 & 0 & 1,00 & 0,43 & 0,97 & 0,82 & 0,75 & 0,46 & $+0,67$ \\
\hline Carassius catratus gibelio & $\mathbf{P}, \mathbf{Y}$ & 2 & & & & & & & $-0,99$ & $-0,46$ & $-0,72$ \\
\hline Naphal Lepomis gibbosus & $\mathbf{P}$ & 1 & 0,19 & 0,01 & 0,33 & 0,01 & 0,67 & 0,22 & $-1,00$ & 0,38 & $+0,11$ \\
\hline K ́nai razbóra Pseudóras bora parva & $\mathrm{P}, \mathrm{V}, \mathrm{N}$ & 1 & 0,97 & 0,01 & $-0,16$ & $-0,26$ & $-0,19$ & 0.27 & 0,89 & 0,72 & $+0,28$ \\
\hline Süger Perca fluviatilis & $\mathrm{v}$ & 1,2 & 0,97 & 0,91 & & & 0,98 & 0,82 & $-0,17$ & $-0,83$ & $+0,45$ \\
\hline Lapos-deverkeszeg Abramis ballerw' A broma & $\mathbf{F}, \mathbf{V}$ & 3 & 0,96 & & & & & & & & $+0,96$ \\
\hline Abramis ballenus/A. brama & $\mathbf{F}, \mathbf{V}$ & 1,2 & & 0,33 & & 1,00 & 0,99 & 0,08 & & & $+0,60$ \\
\hline Küsz Alburnus alburnus & $\mathrm{N}$ & 1 & 0,50 & 0,65 & $-0,06$ & 0,05 & $-1,00$ & $-0,99$ & & & $-0,14$ \\
\hline Vörösszántryú keszeg Scardinus en thropithaimus & $\mathrm{y}, \mathrm{N}$ & 2 & $-1,00$ & 0,33 & $-1,00$ & 0,67 & 0,98 & 0,97 & & & $+0,16$ \\
\hline Szivárványos ökle Rhodeus sericeus amarus & $\mathrm{P}, \mathrm{V}$ & 1 & $-1,00$ & & & & 0,95 & $-1,00$ & & & $-0,35$ \\
\hline Bodorka Rutitus rutilus & $\mathrm{M}, \mathrm{F}$ & 1 & & 0,39 & & & 0,95 & $-1,00$ & 0,18 & 0,60 & $+0,39$ \\
\hline Csíkok Misgurnus fossitis/Cobitis taenia & $\begin{array}{l}\mathbf{F} \\
\mathbf{F} \mathrm{Y}, \mathrm{P}\end{array}$ & ${ }_{1,2}^{1,3}$ & $\begin{array}{r}-1,00 \\
-1,00\end{array}$ & $-0,0,0$ & 0,59 & 0,00 & 0,95 & $-1,00$ & $-1,00$ & $-0,55$ & $-0,20$ \\
\hline
\end{tabular}

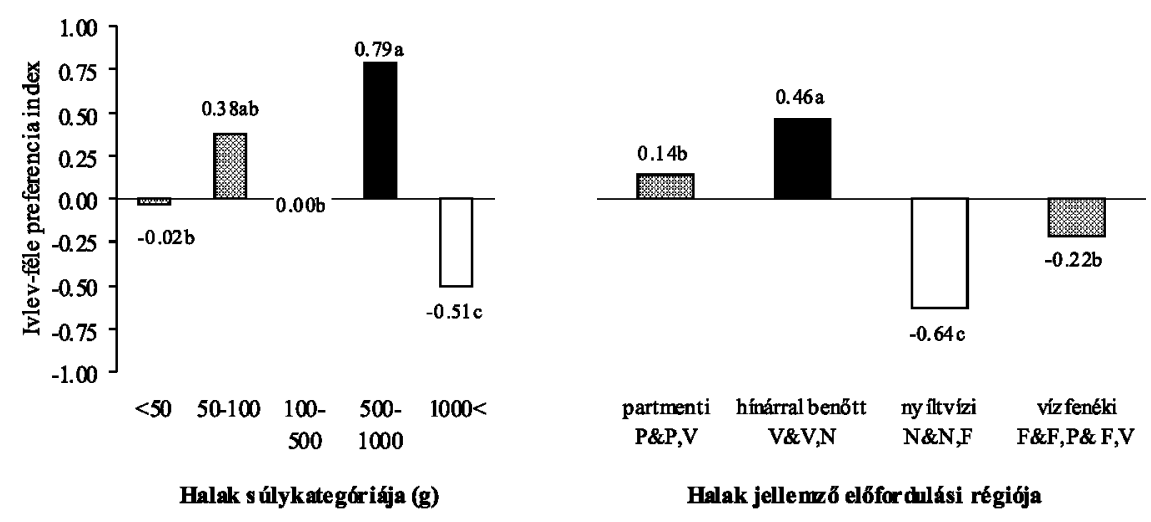

\section{4. ábra: A vidra halpreferenciája a halak súlyától és víztérben való jellemző} elöfordulásától függően

Megjegyzés: a halak jellemzó víztérben való előfordulásának rövidítései: $\mathrm{P}=$ partmenti régió, $\mathrm{V}=$ vízinövényekkel (hínártársulásokkal) benött régió, $\mathrm{N}=$ nyíltvízi régió és $\mathrm{F}=$ vízfenék közeli régió. 
vidra számára legkedvezőbben és valószínüleg leggazdaságosabban zsákmányul ejthető az 500-1000 g mérettartomány, melyre határozott (pozitív) preferencia tapasztalható. Az 500 g-nál kisebb méretü halak esetében vagy nincs (100 g és 500 g között, valamint 50 g alatt), vagy kismértékủ preferencia (50-100 g) tapasztalható. Például az általában nagy gyakorisággal elooforduló, kis testméretü razbórát és naphalat előfordulásuk gyakoriságával közel megegyező mértékben fogyasztotta a vidra.

A preferencia indexek értelmezésénél célszerü figyelembe venni többek között a halak ívásának időszakát, a fajösszetételt, az állománysúrűséget, az egészségi állapotot, a préda fajok mimikrijét, preferált előfordulását a víztérben. A fajösszetétel ismeretének gyakorlati fontosságát a süllốpreferencia esete példázza. Ez a faj a legértékesebb hal, melyet eutróf halastavon elő lehet állítani. A vidra a kisméretű (átlagosan $150 \mathrm{~g}$ ) süllőt általában nem kereste vadászútja során, azonban a Fonói tavon, a 6. évben mégis jelentös süllöpreferenciát lehetett tapasztalni. Ebben közrejátszott, hogy a haltáplálék-készletben a halak döntő többsége a vidra által kevéssé preferált $500 \mathrm{~g}$ alatti tartományba tartozott. Ezért a vidra a lehetőségekhez alkalmazkodva a kisebb méretú, számára könnyen zsákmányul ejthetổ halakat, köztük a kis méretú süllöt is fogyasztotta.

A vízfenék közelében és a nyíltvízen tartózkodó halakat (pl. az $1000 \mathrm{~g}$ feletti pontyot és busát), valamint a környezetébe (vízfenék színébe) olvadó harcsát és compót a vidra általában nem vadászta. A sekélyebb, vízi növényzettel borított, viszonylag tiszta vizú part menti régiót előnyben részesítő 100-500 g-os csuka és ezüstkárász, valamint a vízinövényekkel benött területen élö sügér könnyebben észrevehető és elejthetô zsákmányt jelent a vidra számára. Könnyebb észrevehetóségük miatt ezek az előfordulásuknál általában nagyobb gyakorisággal találhatók meg a vidra táplálékában. A haltermelési időszakon kívül $\left(\mathrm{FHTk}_{\mathrm{II}}\right)$, a patakban viszonylag kevés faj élt. Ebben az időszakban a patakra jellemző halfajokat, így a vízfenéken élő, iszaplakó csíkféléket is preferálta a vidra, melyeket máskor mellőzött. A vizsgálatok összhangban állnak KRUUK (1995) megállapításával, miszerint az eutróf tavakban jellemző kis látótávolság $(\mathrm{kb} .70 \mathrm{~cm})$ akadályozza a mélyebb, nyílt vizekben elóforduló, nagyobb méretü halak zsákmányolását.

A preferencia adatok alapján megállapítható, hogy a vidra halastavi károkozása megelőzhető, vagy mérsékelhető járulékos halfajok, pl. ezüstkárász, kárász, keszegfélék telepítésével, vagy legalább kis egyedszámban való megtủrésével. Leginkább a területre jellemzố, természetes halállomány egy részének fenntartása lenne célszerủ (KEMENEs és NECHAY 1990). Ezek a halak nem jelentős konkurensei a gazdaságilag fontos pontynak, emellett táplálékforrását képezhetik ragadozó halaknak, például a csukának is. A halastavi gazdálkodásban jelentős termeléskiesést okozó kínai razbóra és naphal általában fontos táplálékát képezik a vidrának. Azonban ezen adventív gyomhalak elszaporodása és károkozása a jelentkező vidrakárnál sokkal jelentősebb is lehet.

Speciális teleltető tavakon az elektromos kerítés alkalmazása hatékony a vidrakár megelőzésében; ám sajnos a villanypásztor is őrizetet igényel (de nem a vidra miatt). A védelem nélküli tároló tavakon a fentiektôl lényeges eltérések tapasztalhatók.

\section{A vidra tápláléka a különböző Dráva-menti élőhelyeken}

A vizsgált Dráva-menti területek között, a szigorú határzóna őrizetnek köszönhetően természetes állapotban fennmaradt élöhelyek is szerepelnek. Ezen kívül megtalálhatók köztük horgászat vagy turizmus által befolyásolt, de még természeteshez közeli vizes élöhelyek. Valamilyen emberi behatás mindenhol tapasztalható, például a Dráva folyón Ausztriában, Szlovéniában és Horvátországban jelenleg is tucatnyi kisebb vízerómú múködik. A folyó ennek ellenére ma is Európa egyik legzabolátlanabb vadvize; a Drávát 
övező erdők, holtágak még gyakran az érintetlenség benyomását keltik. Szomorú aktualitás, hogy horvát területen Novo Virje térségében monumentális erómúvet terveznek megépíteni. A Dráva folyó Somogy megyei szakaszán megkezdett természeti monitoring vizsgálatai alapján ez alapvetően befolyásolja majd a Dráva-mente vízgazdálkodását és ezen keresztül növény- és állattársulásait.

\section{A vidra táplálék-összetétele}

A vidra fố táplálékát bőséges haltáplálék-készlet esetén halak alkották a Dráva folyón, a tavakon és a holtágakon. A Dráva-menti haltáplálék igen változatos képet mutatott, az élőhelyek jellegétől függően alakult a fajösszetétel (7. és 8. melléklet). Például a sebes vízfolyást kedvelő fajok közül a márna is megtalálható a táplálékban. A Bélavár melletti holtágon gyưjtött vidra ürülékben talált tokfélét és márnát valószínüleg a közelben folyó Dráván ejtette zsákmányul a vidra. Az elmocsarasodó élőhelyeket jelző szivárványos ökle, compó, vagy csíkfélék inkább holtágakban, valamint a Barcsi Borókás Tájegység felhagyott halastavaiban fordultak elő gyakrabban zsákmányállatként. A fogassüllő fốként a téli-tavaszi, a bőséges vízutánpótlásos időszakban, a csuka viszont egész évben szerepelt a vidra étlapján.

Tanulságos a horgászattal hasznosított tavakon és holtágakon élő vidrák haltápláléka. A somogyudvarhelyi kavicsbánya tavakon a fajokban szegény táplálék döntő részben törpeharcsából és ezüstkárászból állt. Érdekes esetet sikerült itt megfigyelni: a part közeli jégre kéttucatnyi törpeharcsa fejet "tett ki" a vidra. A Barcs melletti Kisbóki holtágon a vidra fajokban viszonylag gazdag tápláléka hasonló az eutróf halastavakon élő példányokéhoz. Leggyakoribb táplálékot a kisméretú (100 g alatti) törpeharcsa, naphal és ezüstkárász jelentett, de téli-tavaszi időszakban ritkán előfordult ponty $(1,3 \%)$ fogyasztása is.

A vizsgált Dráva-menti élőhelyeken a vidra táplálékában a halak alacsony, kb. 50-60\% alatti előfordulási gyakorisága azt jelzi, hogy a halkészlet nem állt rendelkezésre megfelelő mennyiségben. Ezen kívül az évszakok (időszakok) között nagymértékű volt a halkészlet ingadozása. Ilyen esetben a másodlagos táplálékforrások szerepe nő meg, melyek leggyakrabban kétéltűek, vagy ritkábban madarak lehetnek. A madarakból, kétéltűekből és hüllőkbő́l álló táplálék, a Dráva mentén fajokban gazdagabb volt, mint a halastavakon. Különösen érvényes ez a bélavári holtágra a babócsai Ó-Drávára és a Barcsi Borókás középrigóci tavaira. A tipikus másodlagos források szerepe azonban böséges halellátottság mellett nem több kb. 20\%-nál. Amennyiben további táplálék taxonok, pl. emlősök és gerinctelenek szerepe (is) jelentőssé válik a vidra táplálékában, ez az általános táplálék ellátottság súlyos hiányára hívja fel a figyelmet. Ilyen problémák merültek fel az időszakosan kiszáradó élőhelyeken, pl. a Lankóci-erdőben, a Dombó-csatornán, és általában a csatornákon, patakokon. Kiugróan magas kisemlős és vízi rovar fogyasztás a Barcs-Komlósdi Rinyán fordult elő téli-tavaszi időszakban (7. melléklet), valamint a Babócsai Rinyán egész évben (25. ábra). A táplálékként szereplő kisemlős fajok között vizes élőhelyhez kötődő cickányok, vízi pocok és pézsmapocok, valamint erdeiegér és kistestü pocok fajok egyaránt elöfordultak.

A gerinctelenek aránya egész évben különösen magas volt a Barcs-Komlósdi Rinyán és a Korcsina patakon éló vidra táplálékában (25. ábra, 7. és 8 . melléklet). Az ízeltlábúakból álló táplálék fajokban gazdag volt. A leggyakoribb sárgaszegélyú csíkbogár mellett vízhez kötődő és szárazföldi fajok, víztisztaságot indikáló tízlábú rákok (pl. Dráva folyón, babócsai Ó-Dráván, és a Rinyán) egyaránt előfordultak. A Lankóci-erdố vizes élőhelyein élő vidra táplálék-összetétele részletesebben későbbi alfejezetben található meg. 


\section{Relatív vidrasürüség}

A Dráva mentén végzett vidra biomonitoring két éves tapasztalatai, valamint a vizsgált halastavakon kapott adatok alapján relatív vidrasűrüség becslésre nyílt lehetőség.

A relatív vidrasúrüséget az egységnyi bejárt útvonalhosszra vetített hullatékok száma alapján határoztam meg, más vizsgálatokat figyelembe véve (pl. RoBSON és HuMPHREY 1985, MASON és MACDONALd 1986, PRigioni et al. 1995). A vonal transzekten alapuló metodika azonban hibákat is hordozhat (JEFFERIEs 1985). Lényeges a mintagyűjtési gyakoriság és az útvonal rögzítése, valamint csak hosszabb idősort célszerủ elemezni. Mintagyüjtést befolyásoló tényező az időjárás (az esőzés), a vízállás változása, a vidra szaporodással összefüggő társas viselkedése és az évszakonként eltérő ürítési szokásai is (pl. KRUUK és CoNROY 1987, KRUUK 1995). A vidra előfordulása, egyedsürüsége, zsákmányszerzése, territóriumának kiterjedése, szaporodása és utódszáma függ a rendelkezésre álló táplálék-készlettől (a korábban leírtak szerint). A táplálék-készlet nagyságán kívül lényeges, előfordulást befolyásoló tényező a part menti vegetáció minősége, a part meredeksége és a terület ember általi befolyásoltsága is (CARSS 1995, KEMENES és DEMETER 1994, 1995). Ezért a gyüjtött hullatékok számán alapuló speciális, indirekt vonal transzekt módszert kizárólag az élőhelyek rangsorának, illetve az állapotváltozás nyomon követésére lehetett alkalmazni. A területen élö legkisebb ismert egyedszámot más módszerekkel, például többször megismételt téli nyomszámlálással és méretfelvétellel (Pulliainen 1981, REID et al. 1987, DubuC et al. 1991, JEDRZEJEWSKA és JEDRZEJEWSKI 1998, REUTHER et al. 2000), vagy DNS-szintű vizsgálattal (DALlAs et al. 1999, HANSEN és JACOBSEN 1999, DALLAS et al. 2000, MiLLS et al. 2000), illetve ezek kombinációjával lehet meghatározni.

A vizsgálatok alapján felállított sorrendet az 26. ábra szemlélteti. Ebből látható, hogy legnagyobb a vidrasứrúség azokon az élőhelyeken, ahol az emberi befolyás viszonylag kismértékú (Bélavár holtág tavai, Barcsi Borókás, Babócsa Ó-Dráva), vagy haltermelést folytatnak (Fonói tó, Boronka-melléki TK). Gyakori emberi jelenlét esetén, pl. a horgászattal hasznosított tavakon és holtágakon (Somogyudvarhelyi kavicsbánya tavak, Kisbóki holtág, Örtilosi kavicsbánya tavak), valamint az időszakosan kiszáradó élőhelyeken (Dombó-csatorna, Lankóci égeres) igen alacsony a vidrasűrüség. A Dráván (Örtiloson és Vízváron) a bóséges halellátottság ellenére közepesen alacsony a vidrasúrúség. Ez elsősorban a folyó gyors sodrásával, jelentős vízszint ingadozásával és alacsony vízállás esetén a vidrák számára túlságosan meredek és magas partoldallal függhet össze. A vidrák nem kedvelik a meredek és növényzettel nem megfelelốen borított (túl sưrú vagy kopár) partoldalt (pl. KEMENES és DEMETER 1995, KRUUK 1995). A kiszálló helyek igen fontos szerepet töltenek be a szociális életben: a kommunikáció, a játszás, a tisztálkodás, vagy a territórium határ kijelölése során (pl. DURBIN 1989, KRUUK 1995). Ezeknek a tönkretétele, a parti növényzet irtása (pl. horgászhelynek, csónakkikötőnek), illetve a nagy vízszint csökkenés negatívan hat a vidra elöfordulására. A Dráva partoldalát védö köveken - melyek alacsony vízálláskor emelkednek ki - a vidrák ritkán végeznek területjelölést. Ennek oka, hogy a napi jelentős vízszintingadozás következtében a fontos kémiai és vizuális jelzésnek számító ürülékek túlságosan hamar vízbe mosódnak, így szerepüket nem töltik be.

Megállapítható, hogy a már jelenleg müködő vízierőmüvek is negatív hatást gyakorolnak a Dráva folyón élö vidrák életritmusára. Ưj, nagy erőmü építése esetén a környező vízfolyások és állóvizek további kiszáradása vagy vízszintjének csökkenése, a térségben élő vidrapopulációk stabil elófordulását veszélyeztetheti. 

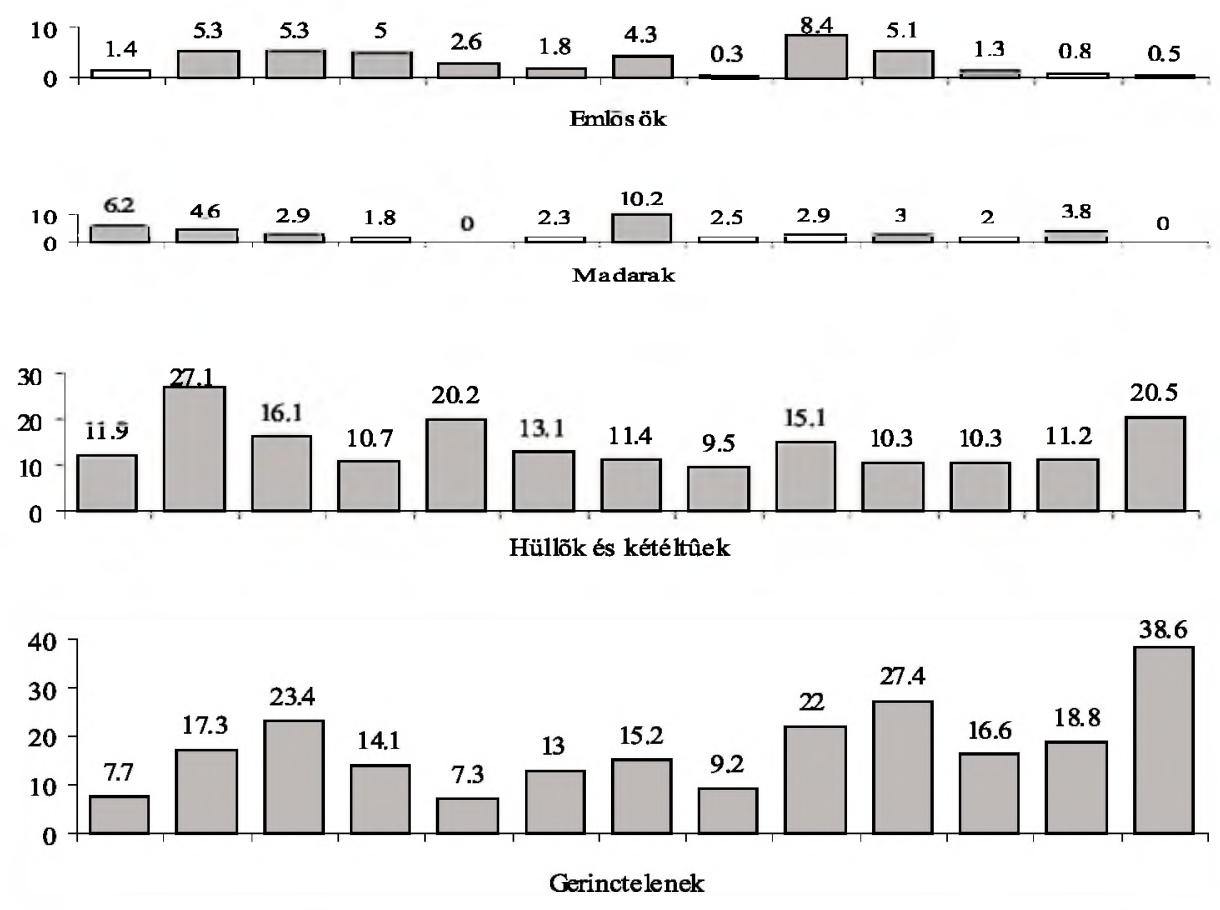

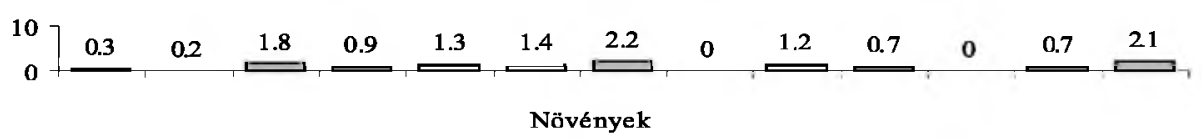

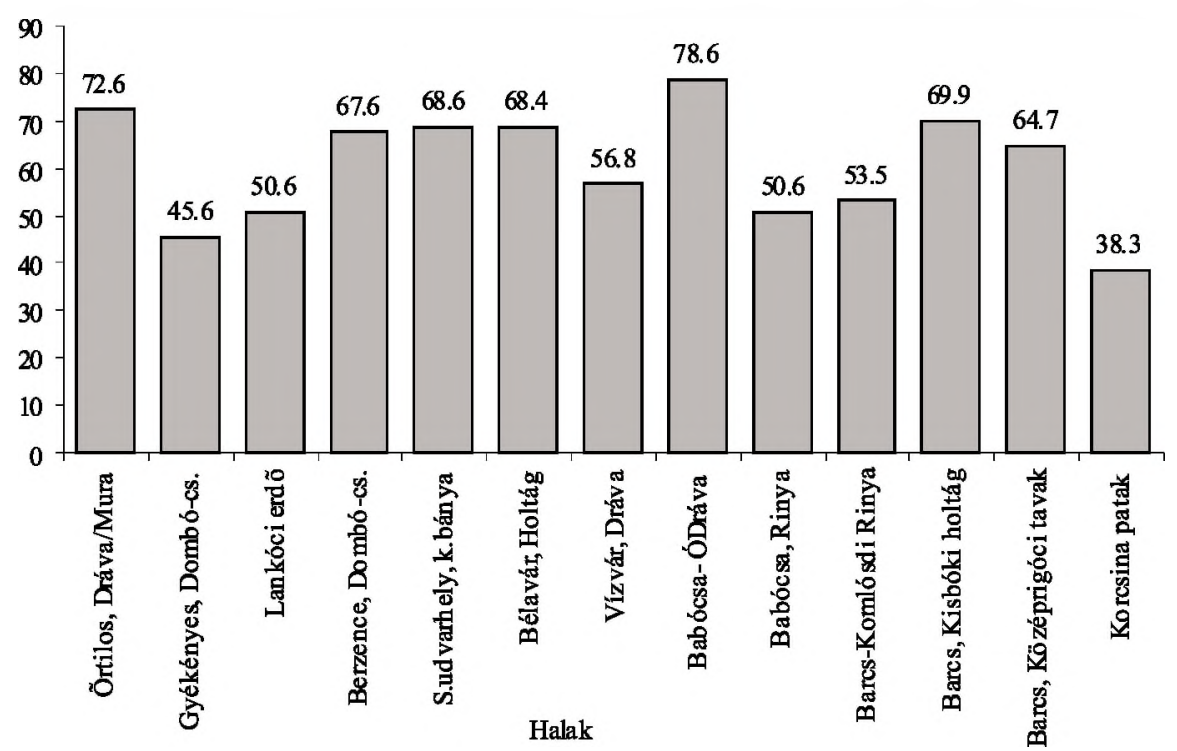

25. ábra: A vidra éves táplálék-összetétele a Dráva-mentén 


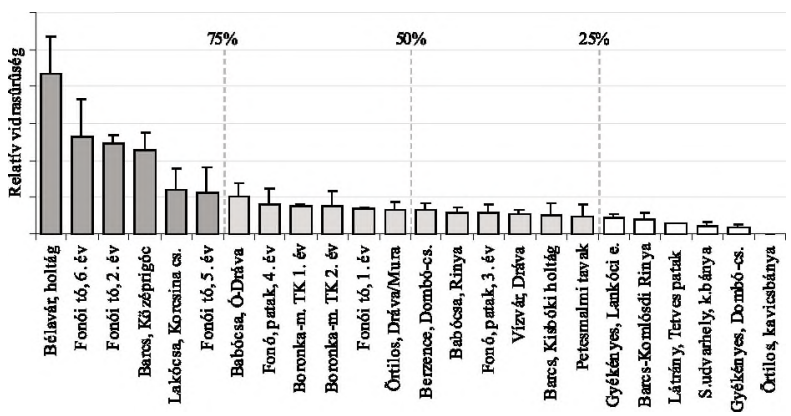

26. ábra: Különbözỏ élőhelyek relatív vidrasủrüségének sorrendje Megjegyzés: A kvartilis határokat szaggatott vonalak jelzik

\section{A vidra tápláléka a biomassza számítás alapján}

Ebben a fejezetben a vidra haltáplálékát - a korábbiaktól eltérően - nemcsak az elófordulási gyakorisági adatok alapján, hanem a hullatékban található táplálék maradványok súlya alapján végzett biomassza számítással is kiegészítve jellemzem (27. ábra, 9. melléklet). A számítás alapját olyan szorzófaktorok képezik, amelyeket a vidra emésztési sajátosságainak figyelembevételével határoztak meg (lásd módszerek fejezetben). Felmerülhet a kérdés, hogy ezeknek az újabb, biomassza számításon alapuló adatoknak mi az értelmük? Vegyünk egy leegyszerüsített példát. Ha a vidra biomassza számításon alapuló táplálék-összetételében $80 \%$-ban szerepelnek halak és $20 \%$-ban békák, akkor ez azt jelenti, hogy $1 \mathrm{~kg}$ elfogyasztott táplálékra $800 \mathrm{~g}$ hal és $200 \mathrm{~g}$ béka jut. (Ugyanilyen módon értelmezhetők a későbbiekben szereplő terresztris fajok adatai is.) Ennek a számításmódnak tehát bárki számára könnyen értelmezhető, gyakorlati jelentôsége van.

A biomassza számítást többféle típusú élóhelyen is elvégeztem, ugyanis a táplálékkészlet függvényében az élőhelyek között eltérések lehetnek.

- A Mike-Petesmalmi tórendszer nagy kiterjedésú erdốk közé ékelódik, természetvédelmi kezelés alatt áll, a tavakon halgazdálkodás folyik. Kiváló adottságokkal rendelkezik az ökoturizmushoz és itt található az ország egyetlen vidraparkja.

- A Duna-Dráva Nemzeti Parkban elterüloo Lankóci-erdőben a vidrák a nyáron kiszáradó égeresben és az erdőben húzódó csatornán, valamint az év nagy részében kiszáradó morotva tavakon és a felhagyott: sással, gyékénnyel borított halastavakon élnek.

- A Látrány határában található Látrányi Puszta Természetvédelmi Terület határán folyó Tetves patak az irmapusztai halastórendszer egyik vízutánpótlása; érdekessége, hogy vizében a kecskerák és a folyami rák egyaránt elôfordul.

\section{A vidra táplálék-összetétele}

A petesmalmi tavakon élő vidra elsődlegesen fontos táplálékát halak alkották, ezek előfordulási gyakorisága évszaktól függően 80 és 94\%, fogyasztott biomasszájuk 94 és 99\% között alakult (27. ábra). Télen legjelentôsebb haltáplálék az ezüstkárász, másodlagosan fontos a törpeharcsa volt (9. melléktet). A tavaszi táplálékban a ponty dominált, szubdomináns az ezüstkárász volt. Nyáron a vidra táplálékában a törpeharcsa részesedése volt a legnagyobb, mellette fogassüllő és sügér fordult még elő jelentősebb mennyiségben. Összel az ezüstkárász és a ponty volt a legjelentősebb haltáplálék, ezek mellett a törpeharcsa fordult elö számottevố arányban. 
Az emlósökből álló táplálékában a vízparton is előforduló pocok fajok, valamint vízpart közelben elhullott vaddisznó és szarvasfélék is szerepeltek (27. ábra és 9. melléklet). A csülkös vad fogyasztása ritkaságszámba megy, ezer táplálékelemból esetleg egyszer fordul elő. Az elfogyasztott nagyvadak a vidrának nem tipikus táplálékai, fogyasztott biomasszájuk elenyészően alacsony. A madarak, a hüllő́k és kétéltúek részaránya is alacsony volt, a korábbiakban ismertetett élóhelyekhez viszonyítva. A gerinctelenekből álló táplálékban a sárgaszegélyű csíkbogár szerepelt leggyakrabban, érdekességként tavaszi időszakban tízlábú rákok is előfordultak az étlapon. Összességében ezek biomasszája alacsony volt, hasonlóan az elfogyasztott növényeké is.

A Lankóci-erdóben élö vidra táplálkozásában az egyébként nem tipikus táplálék taxonok jelentős szerepet töltöttek be. A kisemlösök előfordulása a Dráva-menti területekhez és a halastavakhoz viszonyítva tavasztól őszig általában jelentősebb volt, fogyasztott biomasszájuk 4-7\%-ot tett ki, a fajok közül a közönséges vízicickány érdemel említést (9. melléklet). Madarakat télen nem zsákmányolt a vidra. A kis- és közepes testméretü madarak legnagyobb fogyasztott biomassza arányban $(5 \%)$ tavasszal fordultak elö. $\mathrm{Az}$ alacsony haltáplálék-készlettel jellemezhető legtöbb Dráva-menti patak és csatorna vidra állományához hasonlóan a Lankóci égeresben élő vidra táplálékában is jelentős szerepet töltöttek be a kétéltüek és a hüllők. Arányuk tavasszal, biomassza számítás alapján elérte a $40 \%$-ot, közülük legfontosabbak a különbözó béka fajok voltak. A vidra domináns táplálékát ugyan a halak jelentették, de arányuk jelentös évszakos ingadozást mutatott. A sekély vizekben zömmel $100 \mathrm{~g}$ alatti halak éltek, ezek képezték a vidra fó haltáplálékát. Az égeresben található vizes élőhelyek részleges kiszáradása miatt a vidra táplálékszerzés érdekében távolabbi élőhelyek bejárására is rákényszerült. A haltáplálék fogyasztott biomassza aránya télen 93\%-ot ért el, legjelentősebb faj a csuka, másodlagosan fontos a sügér volt. Tavasszal a halak részaránya $50 \%$ alá csökkent, míg az aszályos nyári, valamint a csapadékosabb öszi időszakban ismét megemelkedett (72-74\%) fogyasztásuk. Ekkor a törpeharcsa, a naphal és a sügér részaránya növekedett meg a táplálékban. A gerinctelenek biomasszája minden évszakban számottevő volt, tavaszszal 5\%-ot tett ki. Legfontosabb szerepet a csíkbogár és a csíbor fajok töltöttek be. A növények fogyasztása elhanyagolhatóan alacsony szinten mozgott.

A Tetves-patakon élő vidra táplálékát nyári és őszi időszakban vizsgáltam (9. melléklet). Kistestú madarak alacsony arányban fordultak elố táplálékként. Ôszi időszakban jelentős volt a kisemlősök, ezen belül a vízipocok fogyasztása (7\%). A kétéltüek és hüllők aránya nyáron is számottevő volt $(21 \%)$, ősszel pedig háromszorosára $(60 \%)$ emelkedett. A táplálékmaradványok között mocsári teknös páncéljának a darabjai is elófordultak. A halak részaránya igen alacsony volt, nyáron csak $17 \%$-ot, ősszel $23 \%$-ot ért el fogyasztásuk. Fenékjáró küllö viszonylag gyakran szerepelt a patakon élő vidra étlapján. A nyári időszakban domináns tápláléka - minden eddig ismertetett élőhelytől eltéróen - gerinctelenekből állt. Az élőhely különlegessége a tízlábú rákok gyakori előfordulása. További jellegzetesség a nyári időszakban tapasztalható igen alacsony vízszint, mely együtt jár a halállomány drasztikus csökkenésével. Ez az oka annak, hogy a vidra táplálékában a tízlábú rákok fogyasztott biomassza aránya nyáron kiugróan magas $(62 \%)$ volt, majd a húvösebb öszi időszakban 9\%-ra csökkent. Nagyarányú rákfogyasztás más élőhelyeken sem ismeretlen. Vizsgálatok szerint (ERLINGE 1967a) Svédország egyes területein gyakran, akár 36\%-os gyakorisággal is szerepelhet vidra táplálékként. A patakon élö vidra táplálékában a növények szerepe nem volt jelentős. 

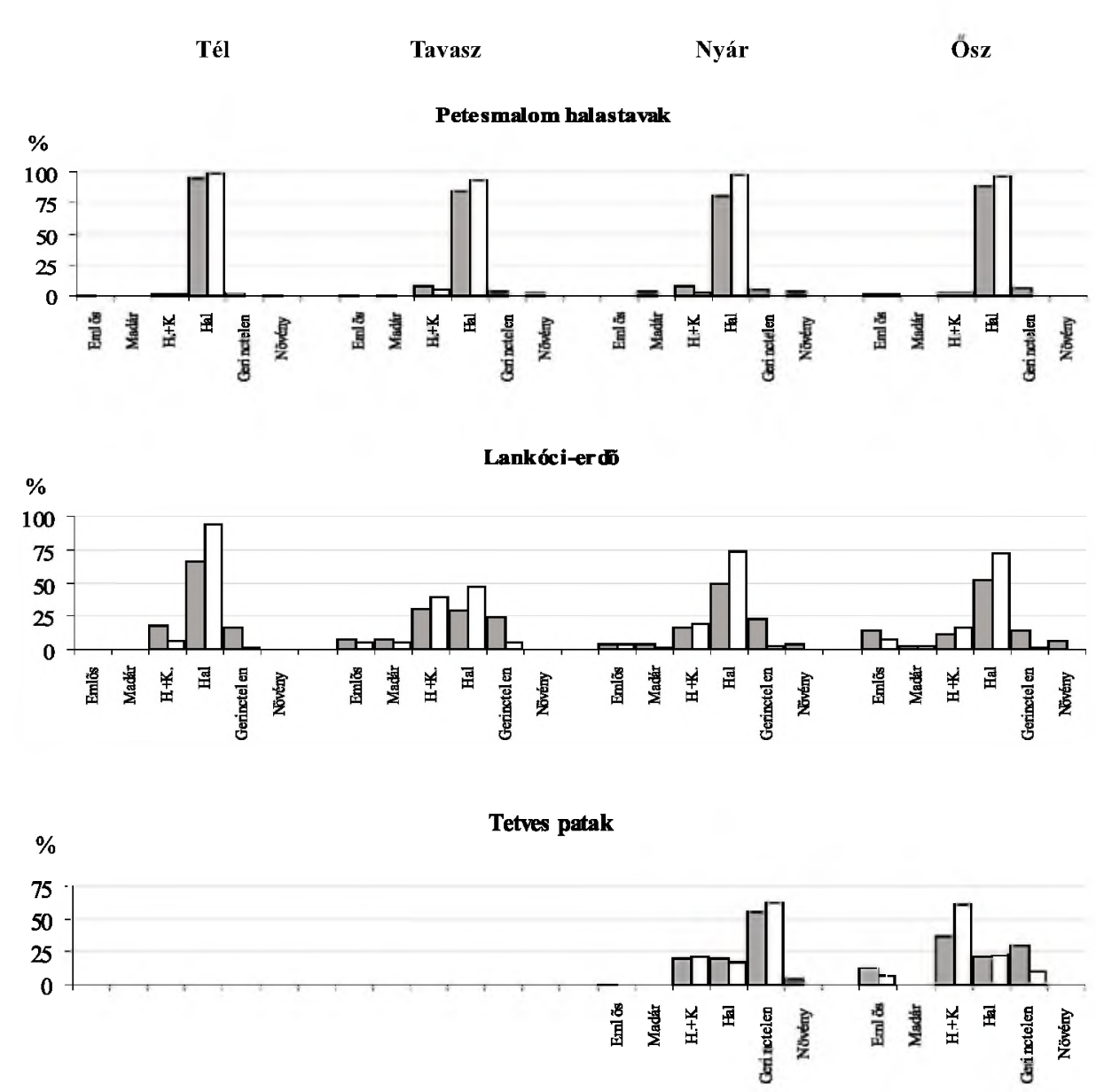

27. ábra: A vidra évszakonkénti táplálék-összetétele előfordulási gyakoriság és biomassza számítás alapján

Megjegyzés: $\mathrm{H} .+\mathrm{K} .=$ hülló és kétéltü együtt, tömör oszlop jelzi a relatív elöfordulási gyakoriság-, és az üres oszlop a biomassza számítás szerint kapott értékeket

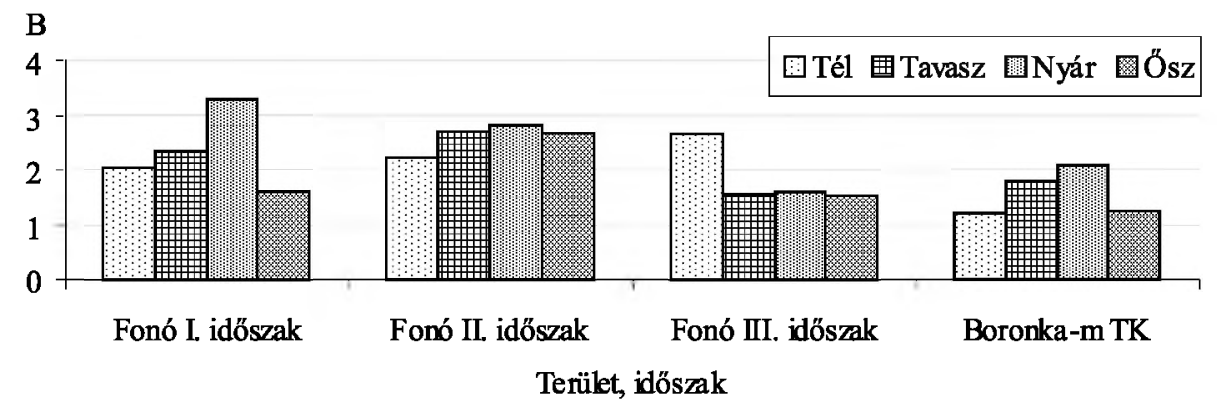

28. ábra: A vidra évszakonkénti táplálkozási niche-szélessége halastavakon 


\section{Korrelációs összefüggések}

A vidra táplálkozása szempontjából legfontosabb halaknak a biomassza számítás szerinti aránya a Petesmalmi halastavakon, évszaktól függően 4-17\%-kal, a Lankócierdőben 21-27\%-kal több volt, mint a relatív gyakorisági adatok (9. melléklet, 27. ábra). A Tetves-patakon a különbség -2-3\%-ot tett ki. A hüllők és kétéltủek biomassza adatai általában kismértékben alacsonyabbak, a többi taxon esetében a biomassza adatok általában kisebbek voltak, mint az előfordulási gyakoriság értékek. Az előfordulási gyakoriság és a biomassza számítás alapján, taxononként kapott adatok közötti Pearson korrelációs összefüggés a következöképp alakult: emlösök $r=0,92,(\mathrm{P}<0,01)$, madarak $\mathrm{r}=$ $0,80(\mathrm{P}<0,05)$, hüllők és kétéltűek $r=0,93(\mathrm{P}<0,001)$, halak $\mathbf{r}=0,90(\mathrm{P}<0,001)$, gerinctelenek $\mathrm{r}=0,88(\mathrm{P}<0,001)$ és növények $\mathrm{r}=-0,78(\mathrm{P}=0,066)$. Az adatok azt jelzik, hogy az előfordulási gyakoriság adatok viszonylag nagy megbízhatósággal reprezentálják a táplálék taxonok fogyasztott mennyiségének alakulását. Ennek az a gyakorlati jelentősége, hogy tógazdaságokban (horgásztavakon) élő vidra táplálékának minőségi (relatív előfordulási gyakoriság) elemzésével is nagy biztonsággal lehet következtetni a táplálék mennyiségi viszonyaira.

\section{A vidra táplálkozási niche-szélessége}

A vidra átlagos táplálkozási niche-szélessége a Fonói halastavon, az I., a II. és a III. időszakban, valamint a Boronka-melléki Tájvédelmi Körzetben eltért egymástól $(\mathrm{B}=$ $2,31,2,59,1,83$ és 1,53 , sorrendben, $\mathrm{P}=0,055)$. Szignifikánsan a legnagyobb táplálkozási niche-szélesség érték (28. ábra) az élöhely kedvezötlenné válásának időszakában (Fonói tó, II. időszak) volt tapasztalható. A halastó rekonstrukcióját követően (a III. időszakban) a niche-szélesség értékek statisztikailag az I. időszakban jellemző szintre csökkentek. A természetvédelmi kezelésben levő területen tapasztalt niche-szélesség érték kissé alacsonyabb volt, mint a Fonói tavon.

A Fonói halastavon és a Boronka-melléki TK tavain tapasztaltakhoz hasonlóan a Dráva folyón, valamint a holtágakon élő vidrák táplálékának általában alacsony volt a nicheszélessége (29. ábra). Jellemzóen alacsony niche-szélességet lehetett tapasztalni a Dráva-menti mesterséges tavakon is, bár az egyes időszakok között nagymértékú volt az ingadozás. A csatornákon és patakokon élő vidrák táplálkozási niche-e általában széles volt, ami az időszakosan változó, de jellemzően kis halsürüséggel és az egyéb táplálékforrások nagyobb arányú hasznosításával függhetett össze.

A Petesmalomban éló vidra táplálkozási niche-szélessége más halastavi (Fonói tó, Boronka-melléki TK) vidrákhoz hasonlóan szükvolt (30. ábra). A Lankóci-erdóben és a Tetves-patakon élố vidra tápláléka változatosabban alakult, amit szélesebb niche-ük is mutat. Jellemző, hogy a biomassza számítás alapján kapott értékek alacsonyabbak, mint előfordulási gyakoriság számítás esetén (a többi ragadozó fajnál is). Ez azzal függ össze, hogy az elsódlegesen fontos táplálék taxon (halak) biomassza adata nagyobb a relatív előfordulási gyakoriság számítás során kapott adattól, ezáltal a táplálék taxonok (képzeletbeli) eloszlásgörbéje még inkább egy irányba tolódik el és még jelentősebb csúcsosságot mutat, mintha csak előfordulási gyakoriság adatokat vettünk volna figyelembe.

A vidrakutatással kapcsolatos további részletek az alábbi sorszámú publikációkban találhatók meg: $[2,3,5,6,7,8,10,11,12,13,14,15,16,17,20,23,24,28,29,31]$. 
B

Dráva

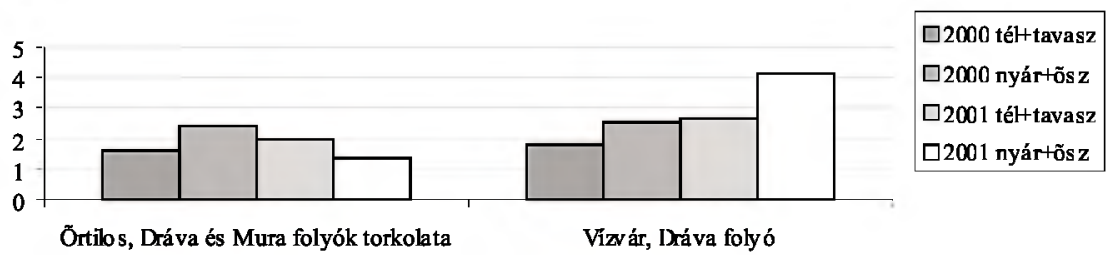

B Holtágak

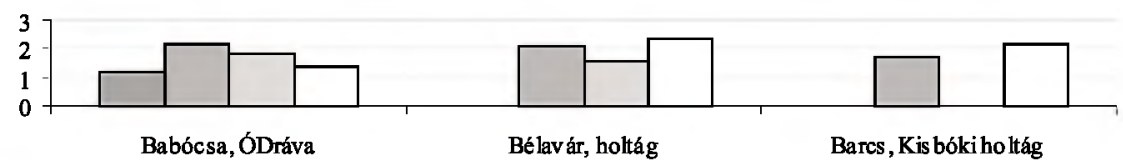

Mes terséges tavak

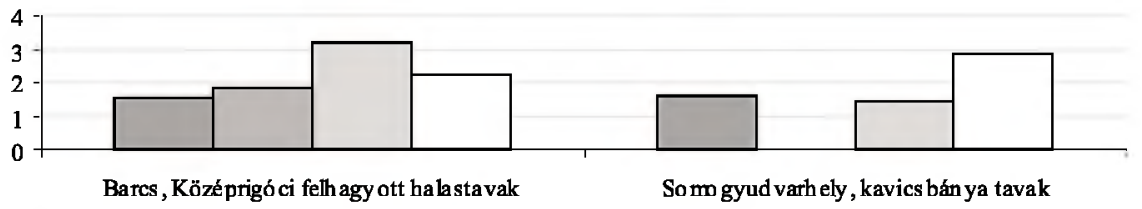

B

Csatornák patakok

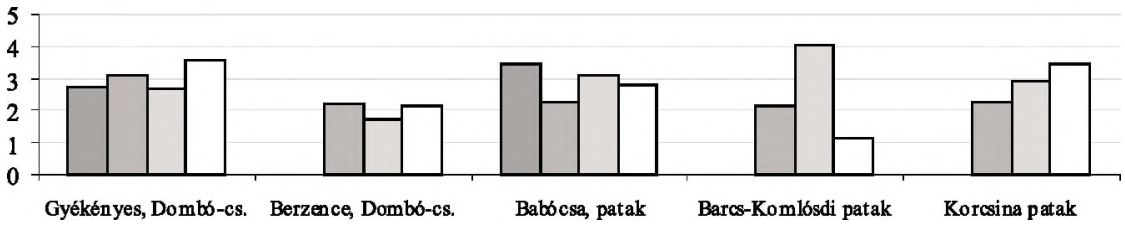

29. ábra: A Dráva-mentén élő vidrák táplálékának niche-szélessége élöhely típusonként Dráva folyó

Petesmalom

Lankóci-erdő

Látrány

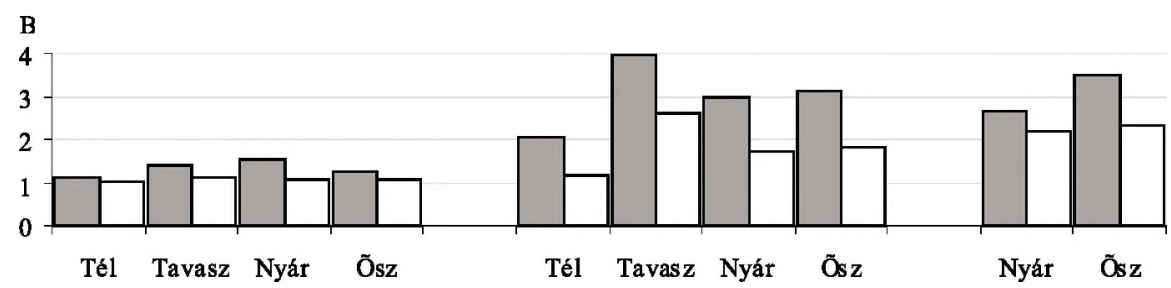

30. ábra: A vidra táplálkozási niche-szélessége előfordulási gyakoriság

és biomassza számítás alapján

Megjegyzés: tömör oszlop relatív előfordulási gyakoriságot, üres oszlop biomassza számítás szerinti öszszetételt jelez 


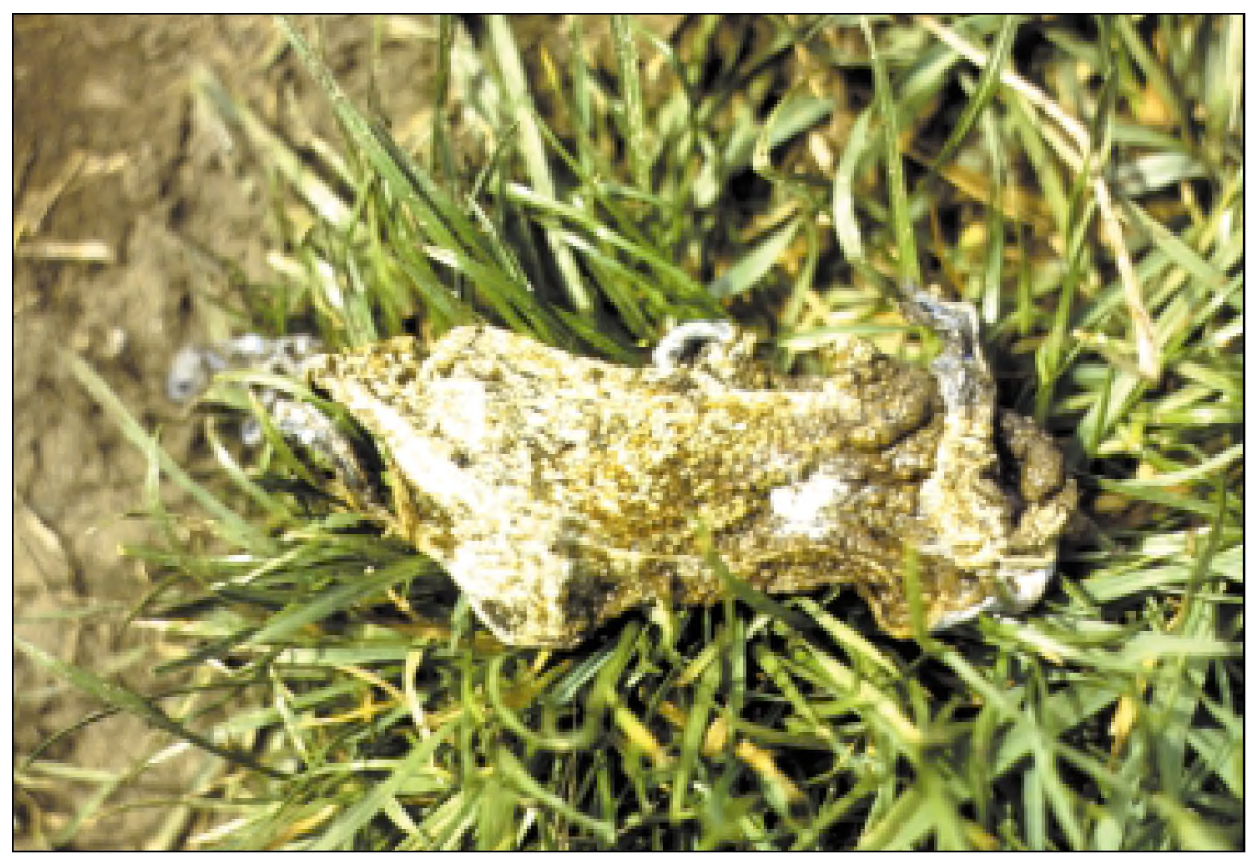

31. ábra: Vidra prédamaradványa (barna varangy megnyúzott bőre)

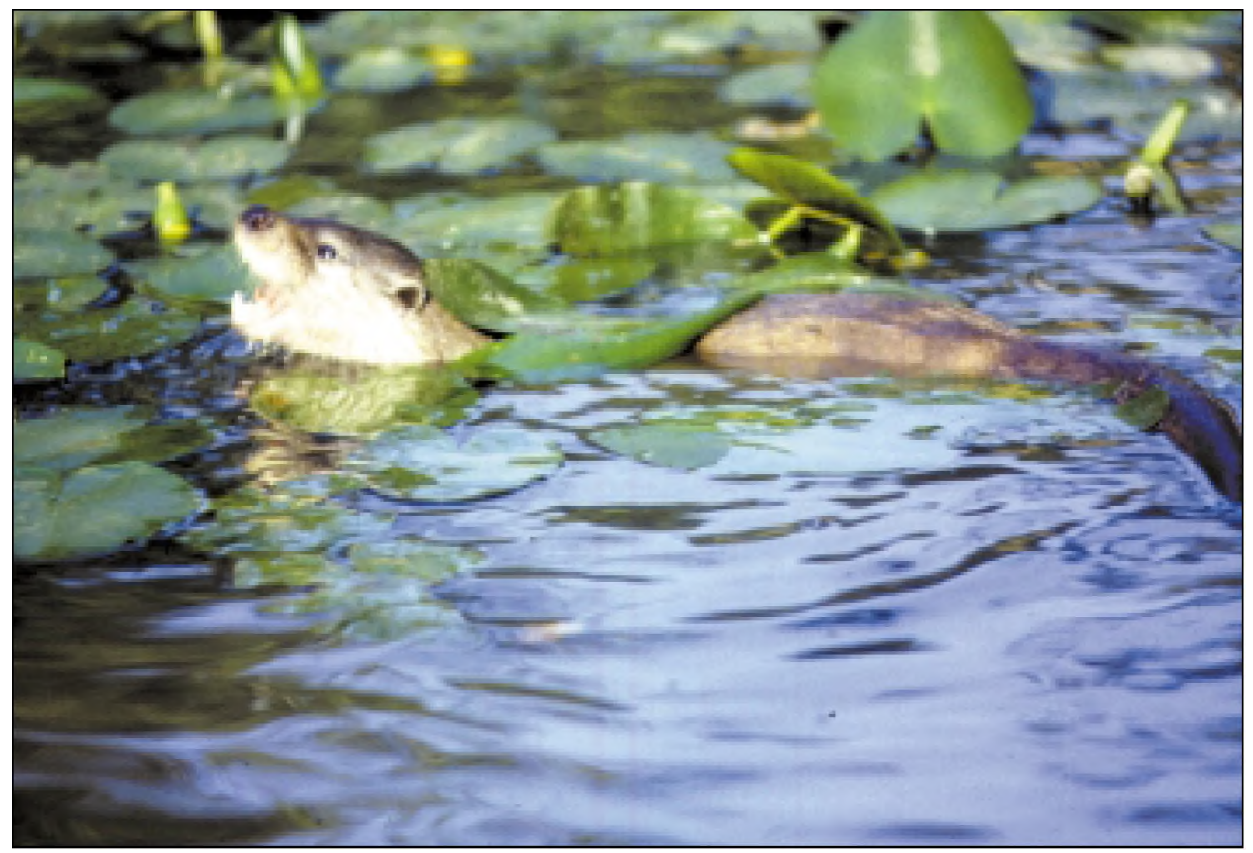

32. ábra: Vidra, természetes közegében 


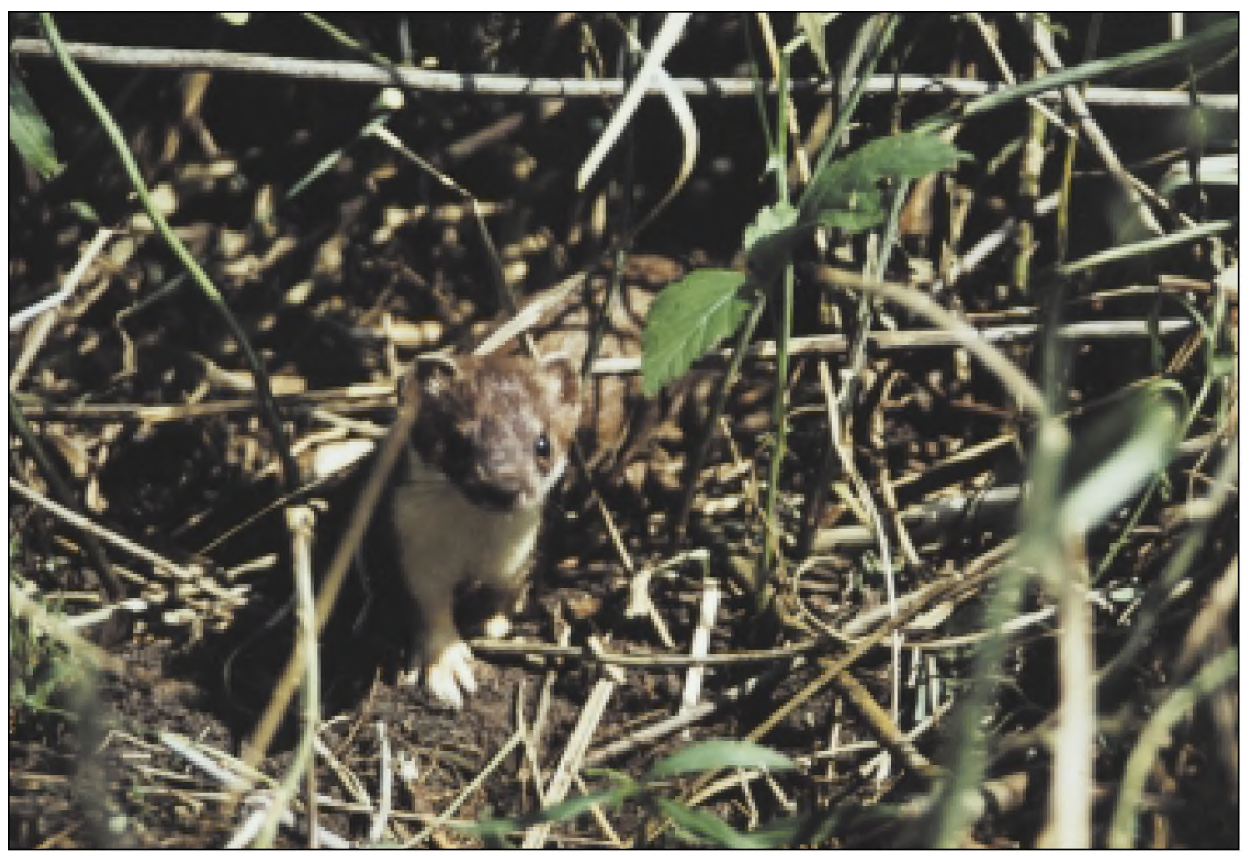

33. ábra: Hermelin (Mustela erminea) nyári bundában (fotó: Tömösváry Tibor)

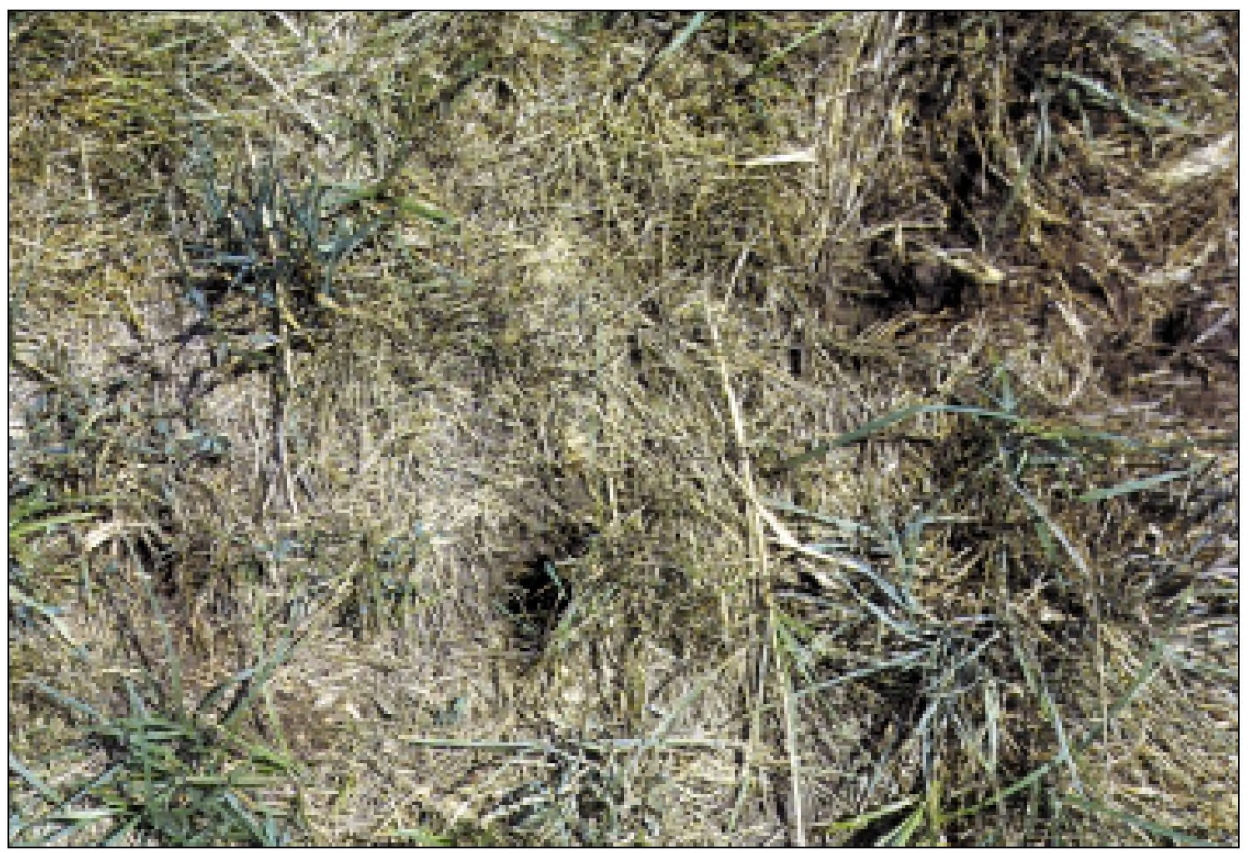

34 ábra: Rágesálók talajszint alatti járatában kialakított hermelin fészek 


\section{A hermelin}

A menyétfélék egyik legkisebb termetü képviselöje a hermelin. Európa középső és északi területein, Ázsiában és Észak-Amerikában elterjedt faj, Új-Zélandra betelepítették (MiTCHELL-JONES et al. 1999). A korábbi évszázadokban hölgymenyétnek is nevezték. Színezete nyáron vörhenyes barna, hasa fehér, megjelenése hasonló a menyéthez, azonban farka viszonylagosan hosszabb annál, a testhosszúság felével megegyezik. A menyéttől színbélyeg alapján is meg lehet különböztetni, ugyanis a hermelin farkának utolsó harmada télen-nyáron fekete színü. A hermelin azon emlósök közé tartozik, melyek színezete a téli hónapokban eltér a nyáritól. A téli fehér, esetenként sárgásfehér, vagy részlegesen fehér-barna szőrzetét novemberben, a nyári szőrzetét márciusban 3-4 hét alatt, tehát rövid idő alatt váltja. Ennek oka, hogy a kistestủ ragadozók mindenkori színezete a rejtőzködést, a környezetbe való beleolvadást szolgálja. Így kerülhetik el, hogy zsákmányul essenek nagyobb ragadozóknak, pl. nyestnek, rókának, egerészölyvnek, gyöngybagolynak; illetve, hogy zsákmányukat észrevétlenül megközelíthessék, s ezáltal saját vadászatuk eredményes legyen. A hermelin törzshosszúsága általában 25-35 $\mathrm{cm}$, lábai rövidek. Teste hajlékony, járás közben hátát kissé púposítja, mint általában a menyétfélék. Kifejezett az ivari dimorfizmus, a hím egyharmaddal nagyobb a nösténynél, testtömege 0,1 és $1,0 \mathrm{~kg}$ között változhat. A testalkata talajszinten, illetve földalatti vadászatra is alkalmassá teszi, de bokrokra is képes felmászni, zsákmányát vízben és hó alatt is tudja követni. Gyakran előfordul, hogy a terep jobb belátása érdekében a hátsó két lábára áll és így fürkészi a környezetét. A hermelin sokféle élőhelyen - de leggyakrabban tavak, patakok, csatornák mentén - fordul elö, ahol általában többféle biotóp is érintkezik, pl. bokorfüzes, erdő, magassásos, rét, halastavak töltése. Ezen kívül változatos élőhelyekkel tarkított erdőkben is találkozhatunk vele. Az emberi településeket a menyéttel szemben általában elkerüli, azonban a téli ínséges időkben a faluszéli baromfi ólakba bemerészkedik a kisrágcsálókért, vagy egy-egy tyúktojás tartalmáért.

A kistestú menyétfélék, így a hermelin és a menyét nagymértékben alkalmazkodnak táplálkozásukban a kisrágcsálók adta lehetőségekhez (ERLINGE 1983). Azokon a területeken, ahol a rágcsálók létszáma jelentősen ingadozik (ciklikus), szoros kapesolat áll fenn a kisrágcsálók és a kisragadozók abundanciája között (pl. GosZCZYNSKI 1977, TAPPER 1976). Más területeken (ERLINGE et al. 1983) a predáció az elsődleges kiváltó ok abban, hogy nem jellemző ciklikusság a rágcsálók populációira. A hermelin populáció struktúráiának és a zsákmányszerzơ magatartásnak vizsgálatára irányuló kutatások eredményei közül néhány fontosabb megállapítást érdemes kiemelni. ERLINGE (1983) hat éven át tartó vizsgálatban, fogás-jelölés-visszafogás módszerrel követte nyomon a hermelin állománynagyságát és populációdinamikáját, a rágcsálósürüség függvényében. Tapasztalata szerint az őszi hermelin sürüség 0,3-1,0 egyed volt 10 hektáronként. Az évtöl függö eltérések elsősorban a vízipocok állományváltozásából adódtak. A téli mortalitás az őszi sűrüségtőll függetlenül, minden évben $50 \%$ körül alakult. A legidősebb hímivarú, illetve nőivarú egyedek 4,5, illetve 3,5 évesek voltak, de a populáció átlagos életkora még a másfél évet sem érte el. Az ivararány 50:50\% körül alakult, de az állomány hanyatlásának szakaszában a hímek száma meghaladta a nőstényekét. A hermelin állo- 
mányát kifejezetten korlátozta a fó táplálék-forrás (90\%); a mezei pocok és a vízipocok állománycsökkenése. A mezei nyúl állománycsökkenése esetén nött a hermelin és a többi predátor közötti kompetíció, a pocokfélék adta forrás kiaknázása érdekében (ERLINGE 1983). Egy másik kísérletben ERLINGE (1977) azt tapasztalta, hogy az őszi időszakban a territóriumot birtokló hímek és nőstények elüzték az azonos ivarú egyedeket a területükrỏl. A talajszint alatt is gyakran vadászó, kisebb testméretú nőstények gyakran kiaknázták a hímek territóriumának egy részén a rendelkezésre álló lehetőségeket. A kifejlett hímek domináltak a nőstények valamint a fiatal hímek felett, melyek csak a hímek territóriumának külső területeit foglalhatták el. A fiatal nőstények leggyakrabban a születésük helyén maradhattak egész életükben. A fiatal hímek ósszel és télen még jórészt a születésük helyén maradtak, de tavasszal nagy távolságokra is elmozdultak. Ebben az időszakban a hímekre növekvő mozgási aktivitás volt jellemző, mely a szaporodóképes hím territóriumára is kiterjedt. A hímek védték territóriumuk határait. A vizsgálat bizonyította a szagjelek, valamint az akusztikus és vizuális jelek fontosságát a territórium védelmében. Territórium foglalást követően a területvédő magatartás elsősorban a táplálkozási kapcsolatok szempontjából volt jelentős.

Egy svájci vizsgálatban a leggyakrabban előforduló táplálékot pocokfélék alkották, közülï̈k is leggyakrabban Microtus fajok és vízipocok fordult elö (DEBRoT et al. 1984). Lengyelországban, erdei élőhelyen a hermelin táplálékának 78\%-át kisemlősök (biomassza: 83\%), a fennmaradó részt békák alkották (JEDRZEJEWSKA és JEDRZEJEWSKI 1998). A kisemlósökön belül a pockok szerepe volt meghatározó. Az erdei pocok elófordulási gyakorisága $39 \%$, az egyéb pockoké $11 \%$, a sárganyakú erdeiegéré $28 \%$ volt. Az Új-Zélandra behurcolt hermelin gyomortartalom vizsgálata során azt tapasztalták, hogy táplálékának döntố részét kistestú madarak és rágcsálók alkotják (KING et al. 1996). A fenti vizsgálatokban tehát a hermelin fó táplálékát saját testsúlyánál kisebb, vagy ahhoz hasonló préda alkotta. Azonban Angliában kora nyári (pontosabban májustól júliusig tartó) időszakban, apróvadas, dombvidéki, mezőgazdasági területeken ennél jóval nagyobb méretú préda fajok gyakori elejtését is megfigyelték a hermelinek csapdázásával és a gyomortartalom vizsgálatával (TAPPER 1976). A kutató szerint a nyár eleji táplálékot 56\%-ban nyúl, 19\%-ban kistestú madarak és 7\%-ban tyúkalakúak alkották. Mindössze a fennmaradó néhány százalékban fordultak elő rágcsálók. Hasonlóan magas arányú (31, ill. $41 \%$ ) kora nyári süldőnyúl, illetve nyúlfióka fogyasztást tapasztalt szintén Angliában DAY (1978). A fentiekből is látható, hogy a hermelin képes alkalmazkodni az élőhelyi adottságokhoz. Tápláléka az élőhelytől függő́en lényegesen eltérhet.

A továbbiakban a dél-dunántúli vizsgálatok eredményét ismertetetem.

\section{A hermelin táplálék-összetétele}

A hermelin táplálék-összetétel vizsgálatát a Fonói halastó körzetében és a Lankócierdóben végeztem. A két terület vegetációja lényegesen eltért egymástól.

A Fonói tó körzetében, a vizsgálati idószak elsố négy évében (I. és II. időszak) a hermelin a halastó északnyugati területrészén, változatos élőhelyeken fordult elő (84. ábra), ahol erdö, szántó, vadföld, kaszálórét, magas sásos és bokorfüzes egyaránt megtalálható volt. A vizsgálat II. időszakának végére a tómederben és a réten a gyomtársulások uralkodóvá válásával, a csatlakozó vizes élóhelyek degradációjával, a vadföld gazdálkodás megszúnésével a korábban ideális élőhely a hermelin számára alkalmatlanná vált. A vizsgálat III. időszakában a területen a mintagyüjtés sikertelen volt. Hermelinek újbóli jelenlétét 1998-tól lehetett észlelni a tóparti cseres-tölgyes erdőben. A vizsgált területen a hermelinek közvetlen megfigyelése és nyomhatározása is megtörtént. A Lankócierdőben a hermelin ürülékek gyưjitését a Dombó-csatorna mentén és az égeresben vezetố utakon végeztem. 
A hermelin domináns tápláléka minden évszakban kisemlősökből állt (35. ábra, 10. melléklet) a Fonói tó körzetében és a Lankóci-erdőben egyaránt.

A Fonói tó körzetében élő hermelin táplálékában a kisemlősök legnagyobb gyakorisággal téli időszakban (71\%) fordultak elő (35. ábra, 10. melléklet). Bár leggyakrabban a sárganyakú erdeiegér $(23,5 \%)$ szerepelt a táplálékban, összességében a legfontosabbnak mégis a pocokfélék (35\%) bizonyultak. Ezek közül a mezei pocok (15\%) volt a leggyakoribb táplálék faj, de előfordult vízipocok és erdei pocok fogyasztása is. Mezei nyúl mindössze egyetlen esetben szerepelt táplálékként. A hermelin téli táplálkozásában a madarak jelentős szerepet töltöttek be, a táplálék negyedét $(26,5 \%)$ alkották. Leggyakrabban kistestü énekesmadarak fogyasztása fordult elö.

Tavaszi időszakban a télihez képest csökkent a kisemlős fogyasztás $(54,5 \%)$ és megváltozott a táplálék faji összetétele is. Lényegesen csökkent az erdeiegerek és nőtt a pocokfélék szerepe. A mezei pocok tette ki a hermelin táplálékának közel harmadrészét (29\%). A táplálékban ritkán előfordultak cickányfélék is. Tavasszal a madarak szerepe lényegesen megnőtt, a táplálék több, mint harmadrészét kistestú énekesmadarak, valamint kisebb részben madártojások alkották. A rovartáplálék szerepe a téli időszakhoz képest nőtt, melyben futóbogarak és darazsak fordultak eló.

Té

$\%$

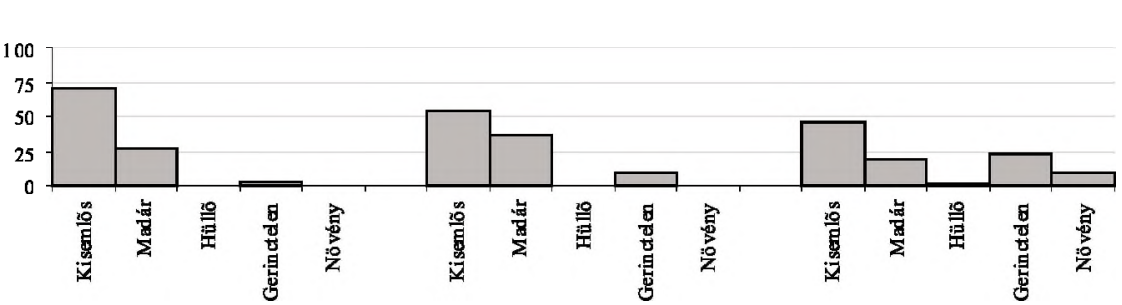

Tél-tavasz

$\%$
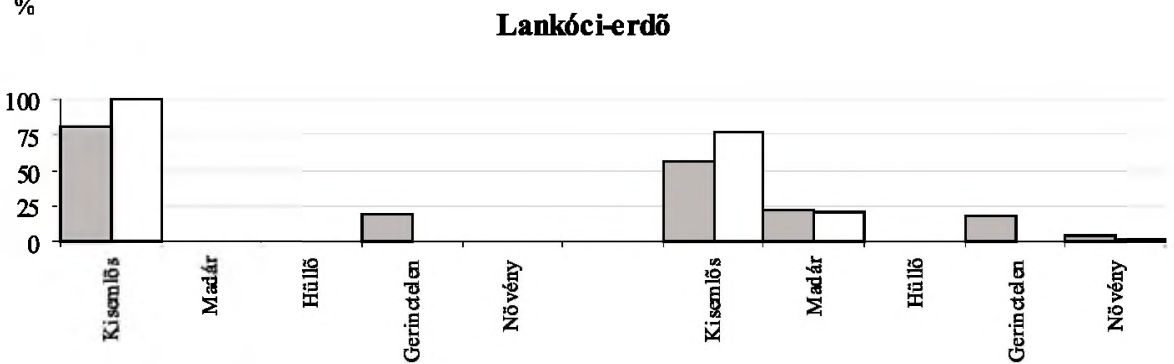

35. ábra: A hermelin tápláléka mezőgazdasági és erdei területen

Megjegyzés: H.+K. = hüllő és kétéltû́ együtt; tömör oszlop jelzi a relatív gyakoriságés üres oszlop a biomassza számítás alapján kapott értékeket 
Az összevont nyári-őszi időszakban szerepeltek a hermelin táplálékában legkisebb gyakorisággal a kisemlősök (46\%). A továbbra is meghatározó pocokfélék mellett elöfordult vakond és mogyorós pele fogyasztás is. A madarak szerepe csökkent (20\%). Emellett előfordult vízisikló fogyasztás, a rovarok részaránya pedig lényegesen megemelkedett (23\%). A téli és tavaszi időszaktól eltéröen gyümölcsökkel és más növényekkel is (összesen 10\%) táplálkozott a hermelin. Háziállatot nem fogyasztott.

A Lankóci-erdőben élő hermelin táplálékát két összevont időszakra vonatkozóan, előfordulási gyakoriság és biomassza számítás alapján is értékeltem.

A téli-tavaszi időszakban a táplálék döntő részét kisemlősök alkották (35. ábra, 10. melléklet). Biomassza számítás alapján ez szinte kizárólagos $(99,8 \%)$ kisemlős fogyasztást jelent. Ezen belül meghatározó szerepe a mezei pocoknak (47\%) volt, de gyakran fordult elő a sárganyakú erdeiegér, az erdei pocok és cickány félék fogyasztása is. A gerinctelenekból álló táplálékban bogarak és darazsak szerepeltek, egyéb táplálék taxon nem fordult elö.

A nyári-ôszi időszakban csökkent a kisemlősök, és nôtt a többi taxon szerepe, bár továbbra is a kisemlösök csoportja maradt elsödlegesen fontos (35. ábra, 10. melléklet). A kisemlósök biomassza számítás szerinti részaránya 77\%, melyben a meghatározó két faj szerepét a mezei pocok (39\%) és az erdei pocok (22\%) töltötte be. A madártáplálékon $(21 \%)$ belül jelentősebb volt a tojásfogyasztás, mint a kistestű madarak predációja. A rovartáplálékban - a téli-tavaszi időszakhoz hasonlóan - bogarak és darazsak szerepeltek. A növények közül például szedret fogyasztott a hermelin $(1,6 \%)$.

A két vizsgált terület eltérô környezeti adottságai ellenére a hermelin populációk tápláléka taxonómiailag nem tért el sem a téli-tavaszi $(\mathrm{P}=0,203)$, sem a nyári-őszi időszakban $(\mathrm{P}=0,199)$.

\section{A hermelin préda fajainak súlya és jellemzö élőhelye}

A hermelin zsákmányának döntő része a Fonói tó körzetében $(79 \%)$ és a Lankócierdöben is (74\%) a 15 és $50 \mathrm{~g}$ közötti súlytartományba tartozott (36. ábra). Ebbe a kategóriába sorolható a legtöbb kisemlős és kistestü énekesmadár (2. melléklet). A 15 g-nál kisebb súlyú csoportba tartozó préda fajok, mint pl. cickányfélék, törpeegér, cinege, rovarok a fonói területen kisebb gyakorisággal $(15 \%)$ fordultak elố táplálékként, mint a Lankóci-erdőben ( $24 \%$ ). Az 50 g feletti kategóriákba sorolt fajok, mint pl. vakond, vízipocok, mezei nyúl, vízisikló pedig ritkán szerepeltek a hermelin táplálékában.

A préda súlya

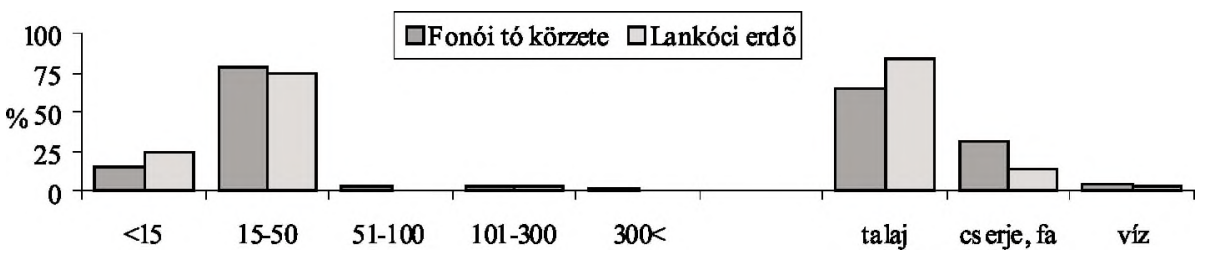

36. ábra: A hermelin prédaválasztása a zsákmány súlya és jellemző előfordulási szintje alapján 
A hermelin zsákmány fajainak többsége talajszinten élt (36. ábra). A Fonói tó körzetében ezek aránya $65 \%$-ot, a Lankóci-erdóben $84 \%$-ot tett ki, de bokrokon élö préda fajok (fóként madarak) viszonylag gyakran - a Fonói területen 31\%-ban, a Lankóci-erdőben 13\%-ban - szerepeltek táplálékként. A hermelin ugyanis kiválóan tud mászni, valamint úszni is. A vízhez kötődô fajok (pl. vízipocok) előfordulási gyakorisága ennek ellenére csak néhány százalékot tett ki, mivel a vizsgált élöhelyeken a könnyen zsákmányul ejthetô terresztris préda fajok elegendő mennyiségben álltak rendelkezésre.

\section{A hermelin táplálkozási niche-szélessége}

A hermelin táplálkozási niche-szélessége a Fonói tó körzetében téli-tavaszi időszakban 3,54, nyári-őszi időszakban 5,99, a Lankóci-erdőben időszaktól függetlenül 2,84 volt (37. ábra). A Fonói területen, különösen a nyári-ószi időszakban kapott magas érték abból adódott, hogy a hermelin által hasznosított viszonylag sokféle táplálékforrás között nem voltak kiugróan magas aránnyal szereplô taxonok. Ennek ellenére a hermelin tápláléklistája a többi vizsgált ragadozó emlős fajhoz viszonyítva meglehetősen szegényes (10. melléklet).

Összességében megállapítható, hogy a hermelin legfontosabb táplálékát a kisemlősök, ezen belül is a pocokfélék alkotják. A kisemlósök aránya télen a legnagyobb, majd a nyári-őszi időszakig fokozatosan csökken. Ezzel együtt a madarak, valamint a rovarok szerepe nô a táplálkozásban. Ritkán előfordul hüllők és növények fogyasztása is. A lényegesen eltéró mezógazdasági és erdei élőhelyeken is vizsgált hermelin tápláléka fajokban szegény, ennek ellenére a fô taxonok alapján táplálkozási niche-e széles. Zsákmányainak súlya jellemzően 15 és $50 \mathrm{~g}$ közé sorolható. Préda fajainak döntő többsége talajszinten él, de jelentősek a cserjék szintjén élók, valamint ritkán előfordulnak vizes élóhelyhez kötődő fajok is.

A hermelin kutatásával kapcsolatos további részletek az alábbi sorszámú publikációkban találhatók meg: [2, 5, 6, 12, 13, 14, 15, 17, 23]. 
Fonói tó körzete

Lankóci-erdố

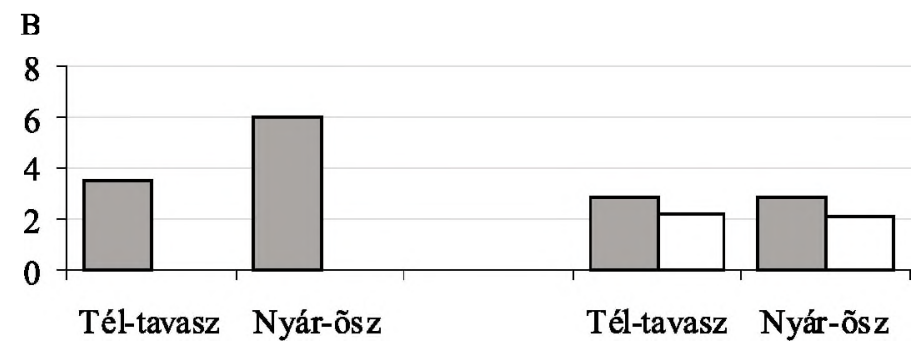

12. ábra: A hermelin táplálkozási niche-szélessége mezôgazdasági és erdei területen Megjegyzés: tömör oszlop jelzi a relatív gyakoriság- és üres oszlop a biomassza számítás alapján kapott értékeket 


\section{A nyest}

A nyest széles elterjedésủ tipikus generalista ragadozó. Valaha jellemzően erdei élóhelyeken élt, napjainkban azonban nemcsak erdei és mezögazdasági területeken, hanem különbözó emberi településeken: a falvaktól a nagyvárosokig megtalálható, ahol gyakran konfliktusok forrásává válik (MiTCHELL-JONES et al. 1999).

A nyest táplálék-összetételét számos tanulmányban elemezték mezőgazdasági környezetben (GoszCZynski 1977, RASMUSSEN és MADSEN 1985, Goszczynski 1986, Tester 1986, Lode 1994, Posillico et al. 1995, PANDOLFI et al. 1996), mediterrán területen (SERAFINI és LoVARI 1993), valamint hegyvidéki erdei és sziklás élöhelyeken (DELIBES 1978, LuCHERINI és CREMA 1993, BRANGi 1995). Annak ellenére, hogy a nyest közönséges faj, az emberi településeken előforduló populációk életmódja kevésbé kutatott (pl. Dánia: Rasmussen és MADSEn 1985, Olaszország: LuCHERIN és Crema 1993, Svájc: Tester 1986, Cseh Köztársaság: Holisová és OBRTEL 1982, Belorusszia: Sidorovich 1997, Magyarország: TóTH-APÁTHY 1998). Az eltérő földrajzi szélességen, különböző típusú élőhelyeken végzett táplálék-összetétel vizsgálatok azt jelzik, hogy az „urbánus“ és a „természetes“ körülmények között élő nyestek időszakosan ugyan, de hasonló táplálékforrásokat is hasznosíthatnak. Ez elöre vetíti azt a feltételezést, hogy elöfordulási helyük szerinti besorolásuk legfeljebb általánosságban lehet érvényes. Adott településen belül és azon kívül élő nyestek közötti táplálkozási kapcsolatok alig ismertek, mindöszSZe RASMUSSEN és MADSEN (1985), valamint TESTER (1986) végzett összehasonlítást.

A jelenlegi vizsgálat a Fonói halastó körzetében, tipikus mezőgazdaságilag művelt területen, valamint Fonó községben élö nyestek táplálék elemzése alapján zajlott. Ennek megfelelóen ebben a fejezetben mezőgazdasági és urbánus környezetben élő nyestek összehasonlító táplálkozás vizsgálata található. Az „urbánus“ jelzót elvileg a városi nyestekre kellene használni, mivel a rendelkezésre álló táplálék-források eltérnek a kis falvaktól. Ennek ellenére ezt a jelzőt alkalmazom, mert a vizsgált élőhely ebben az esetben is alapvetően emberi befolyás alatt áll.

\section{A nyest táplálék-összetétele mezógazdasági és urbánus környezetben}

A Fonói halastó körzetében, valamint a településen élô urbánus nyest táplálék-összetétele taxonómiailag nem különbözött $(\mathrm{P}=0,070)$, táplálkozási niche-átfedésük nagymértékü volt $(78,5 \%)$.

A mezőgazdasági környezetben élő nyest téli és tavaszi táplálékában a kisemlôsök elsődlegesen fontos szerepet játszottak (35-40\%), nyáron és ósszel viszont a növényfogyasztás vált jelentôsebbé (45-46\%).

Éves összesítésben a mezógazdasági környezetben élố nyest zsákmányai között a kisemlösök (30\%), ezek közül is a pocokfélék (elsősorban a mezei pocok) voltak a legjelentósebbek (38. ábra és 11. melléklet). A kisemlős táplálék változatosabb volt, mint az urbánus nyesté, mert például denevér, vakond, mókus, mogyorós pele és pézsmapocok is elófordult benne. A mezei nyúl táplálékként ritkán (0,3\%) szerepelt. Az urbánus nyestek táplálékában a kisemlősök lényegesen kisebb szerepet játszottak $(15,5 \%)(38$. ábra és 11. melléklet). A kisemlós táplálékban, ebben az esetben a legfontosabb egérfélék (el- 
sősorban a házi egér) mellett előfordult vándorpatkány fogyasztás is. Az emberi településhez kötốdô fajokon kívül azonban elöfordultak táplálékként jellemzően vadon élő kisemlösök, pl. vízipocok, erdei pocok is.

A halastó körzetében élő nyest táplálékában szereplő borz (11. melléklet) nagy valószínúséggel dögfogyasztásból származhatott. Hasonlóképp a vaddisznó és a szarvasfélék is, melyeket zsákmányul ejteni nem képes. Ragadozó emlős és csülkös vad az urbánus nyest táplálékában egyáltalán nem szerepelt.

Mindkét élőhely nyestjei fogyasztottak háziállatot, de eltérő arányban (38. ábra és 11 . melléklet). A halastó körzetében, odvas fákban és a tóparti halászház padlásterében fészkelő egyedek táplálékában a háziállatok éves viszonylatban 4\%-ban szerepeltek. Ezzel szemben az urbánus nyest táplálékának biomassza számítás szerinti ötödrészét (elôfordulási gyakoriság 15\%) háziállatok alkották. Ezek közül leggyakrabban és legnagyobb mennyiségben baromfifélék és tojásuk fogyasztása fordult elö.

Az urbánus egyedek elsődlegesen fontos zsákmányát a madarak jelentették, a legjelentôsebb faj a házi veréb volt. A mezőgazdasági környezetben élö nyest 50\%-kal kevesebb madarat fogyasztott, mint urbánus rokona (38. ábra és 11. melléklet). Fácán csak a halastó körzetében élő nyest téli táplálékában szerepelt $(0,9 \%)$, azonban ennél is a kistestű énekesmadarak fogyasztása volt a fontosabb.

Tél Tavasz Nyár Oósz

$\%$

Fonói tó körzete
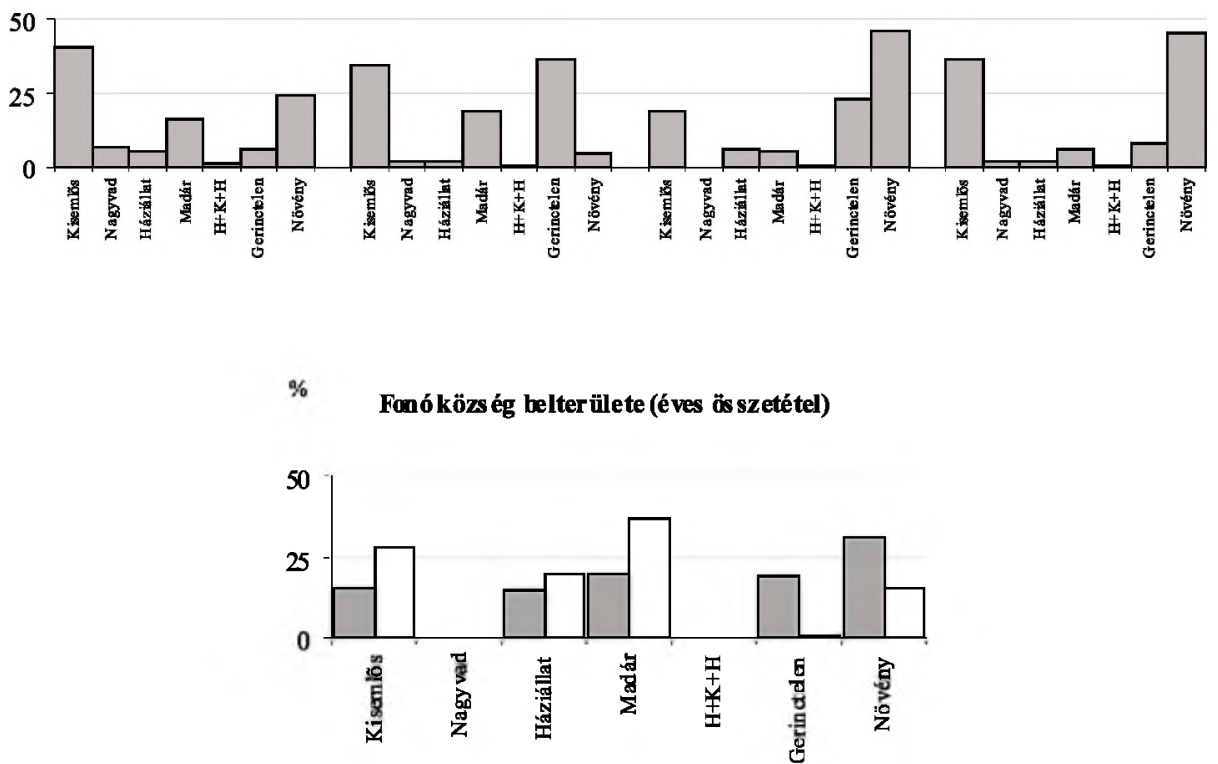

38. ábra: A nyest táplálék-összetétele mezőgazdasági és urbánus környezetben Megjegyzés: $\mathrm{H}+\mathrm{K}+\mathrm{H}=$ hüllő, kétéltű és hal együtt; tömör oszlop jelzi a relatív gyakoriságés üres oszlop a biomassza számítás alapján kapott értékeket. 
Csak a halastó körzetében élő egyedek táplálékában szerepeltek vizes élőhelyhez kötớdó hüllök, kétéltúek és halak (38. ábra és 11. melléklet). Alacsony elöfordulási arányuk azt jelzi, hogy nem jellemző táplálékai a nyestnek.

Gerinctelenek mindkét nyestcsoport táplálékában gyakran (19\%) szerepeltek, de ezek biomasszája elenyészően kicsi volt $(0,5 \%)$. A mezógazdasági környezetben élő nyest gazdagabb rovartáplálékában leggyakrabban futóbogarak, valamint szarvasbogarak fordultak elő. Az urbánus egyedek fóként darazsakat, ritkán háziméhet is fogyasztottak, ezzel együtt feltételezhető a mézfogyasztás is (DELIBES 1978, SERAFINI és Lovari 1993).

A nyestek táplálékában éves viszonylatban a növények jelentették az elsődlegesen fontos táplálékot mindkét élóhelyen (38. ábra és 11. melléklet). A növények közuil is a gyümölcsök szerepe volt meghatározó. A legkedveltebb cseresznye mellette a halastó körzetében élő nyest jelentős arányban fogyasztott vadon termő gyümölcsöket, például (somot, szedret, kökényt), a lakott területen élő pedig szólöt.

Éves összegzésben egyetlen táplálék taxon sem szerepelt 40\%-os arány fölött.

\section{Emészthetetlen anyagok a nyest táplálékában}

A táplálékban előforduló egyéb komponensek (emészthetetlen anyagok) az urbánus nyestnél lényegesen nagyobb gyakorisággal $(\mathrm{P}<0,001)$ fordultak elő, mint a halastó körzetében élőnél. Ezeket az anyagokat feltételezhetően zömmel szemétdombokon, hulladékok között fogyaszthatták. Az elfogyasztott szemét igen változatos képet mutatott, leggyakrabban gumiféleségek fordultak elő (11. melléklet).

\section{A nyest préda fajainak súlya és jellemzö élöhelye}

A préda fajok súlya alapján a nyestek tápláléka szignifikánsan különbözött az élőhelytől függően $(\mathrm{P}<0,001)$. Jellemzóen a 15 és az 50 gramm közötti súlykategóriába eső prédát fogyasztották (39. ábra), mely a tó körzetében élő nyestnél 55\%-ban, a lakott területen élőnél 47\%-ban szerepelt. Az urbánus nyest étlapján az $50 \mathrm{~g}$ feletti préda is jelentős szerepet játszott (14\%).

A fogyasztott zsákmány fajok jellemző előfordulási szintje is különbözött a nyestek élóhelyétől függốen $(\mathrm{P}<0,001)$. A nyestek jellemzóen a talajszint közelében élő prédát fogyasztották ( 81 , illetve $71 \%$ ). A lakott területen élő nyest azonban a bokrokon, ereszek alatt, vagy a fák lombkorona szintjén élö állatokat is gyakran (29\%) zsákmányul ejtette (39. ábra).

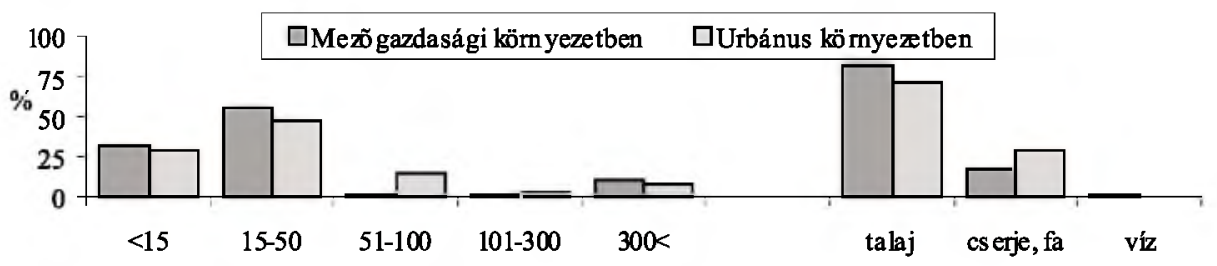

39. ábra: A nyest prédaválasztása a zsákmány súlya és jellemzó élóhelye szerint 
Lényeges eltérés volt tapasztalható a nyestek között a préda fajok jellemző előfordulási helye (kötődése) szerint is $(\mathrm{P}<0,001)$. Az emberi településen kívül élố nyestek a vadon élö préda fajokat, a lakott területen élők pedig az emberhez kötődő fajokat fogyasztották gyakrabban (40. ábra).

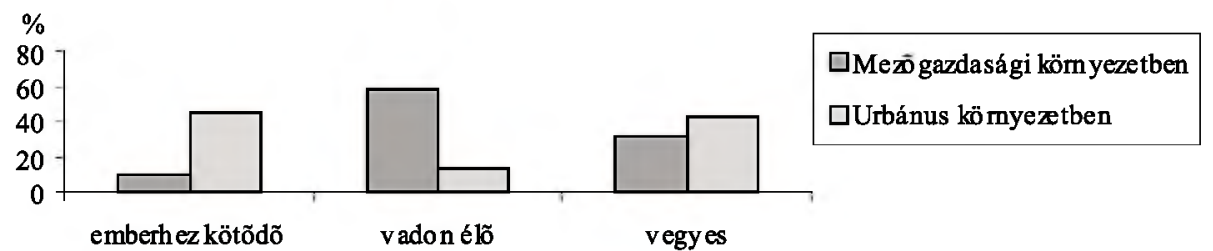

40. ábra: Nyest prédaválasztása a zsákmány élőhelyi kötődése alapján

\section{A nyest táplálkozási niche-szélessége}

A halastó körzetében élö nyest szélesebb táplálék spektrumával többféle állat és növény taxon fogyasztása járt együtt, mint amit az urbánus nyest esetében lehetett tapasztalni. A táplálkozási niche-szélesség mindkét esetben magas volt. Értéke a mezőgazdasági környezetben élőnél 5,39, míg az urbánus nyestnél előfordulási gyakoriság szerint 5,51 , biomassza számítás alapján 4,34 volt.

A vizsgálat alapján megállapítható, hogy az emberi településen kívül és az urbánus környezetben éló nyestek táplálék-összetétele nagymértékben hasonló. A jelentős fajon belüli táplálkozási kompetíciót niche-szegregálódás oldja fel, ezt a megállapítást támasztják alá az alábbiak:

1) élőhelyüktől függetlenül jellemzô, hogy a nyestek táplálkozási niche-e széles, a táplálékforrások igen széles körét képesek hasznosítani,

2) bár jellemzően 15 és $50 \mathrm{~g}$ közötti súlyú prédát zsákmányolnak, az urbánus nyest a nagyobb súlyú prédát gyakrabban részesíti előnyben, mint a mezôgazdasági környezetben élö,

3) az urbánus nyest több bokor-, illetve lombkorona szinten élő és kevesebb talajszint közelében élő prédát fogyaszt, mint a mezőgazdasági környezetben élő nyest,

4) az urbánus nyest nagyobb arányban fogyaszt emberhez kötődó és kisebb arányban vadon (lakott területen kívül) élô prédát. A háziállat fogyasztásban és a a szemétben való keresésben is lényeges különbség tapasztalható az élőhelytől függően.

A nyest opportunista predációját (WAEchTER 1975, GoszczYNSKi 1986, MitcheLLJONES et al. 1999) támasztja alá a jelen tanulmányban szereplő nyestek széles táplálékspektruma és viszonylag kiegyenlített táplálék-összetétele. A különböző élőhelyeken élö nyestek közötti kapcsolatok meglétét a fontosabb táplálék-források közös hasznosítása révén lehet mérni. Felmerülhet a kérdés, hogy mi alapján válnak a nyestek jellemzően emberi településhez kötődő, vagy attól távol élő egyedekké; a környezetnek, illetve az anyának milyen szerepe lehet? A nyesttel rokon közönséges görényen végzett megfigyelés szerint az egyedek táplálék-preferenciáját alapvetően befolyásolja, hogy 2-3 hónapos életkorig az anya milyen táplálékot hordott kölykei számára (BLANDFORD 1987). Ebben az esetben tulajdonképp a préda szaga a meghatározó. Feltételezhetóen ez a tanulási folyamat a nyestre is érvényes. 


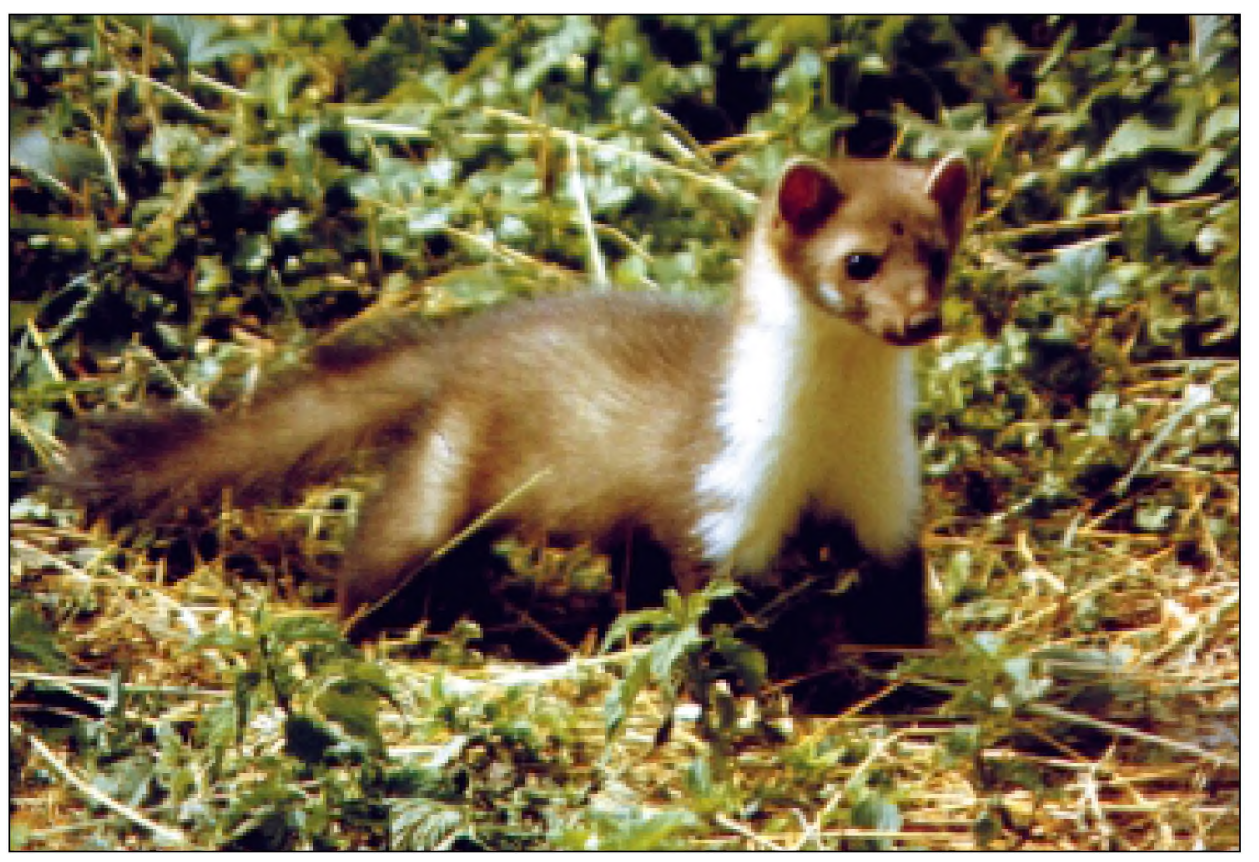

41. ábra: Nyest (Martes foina)

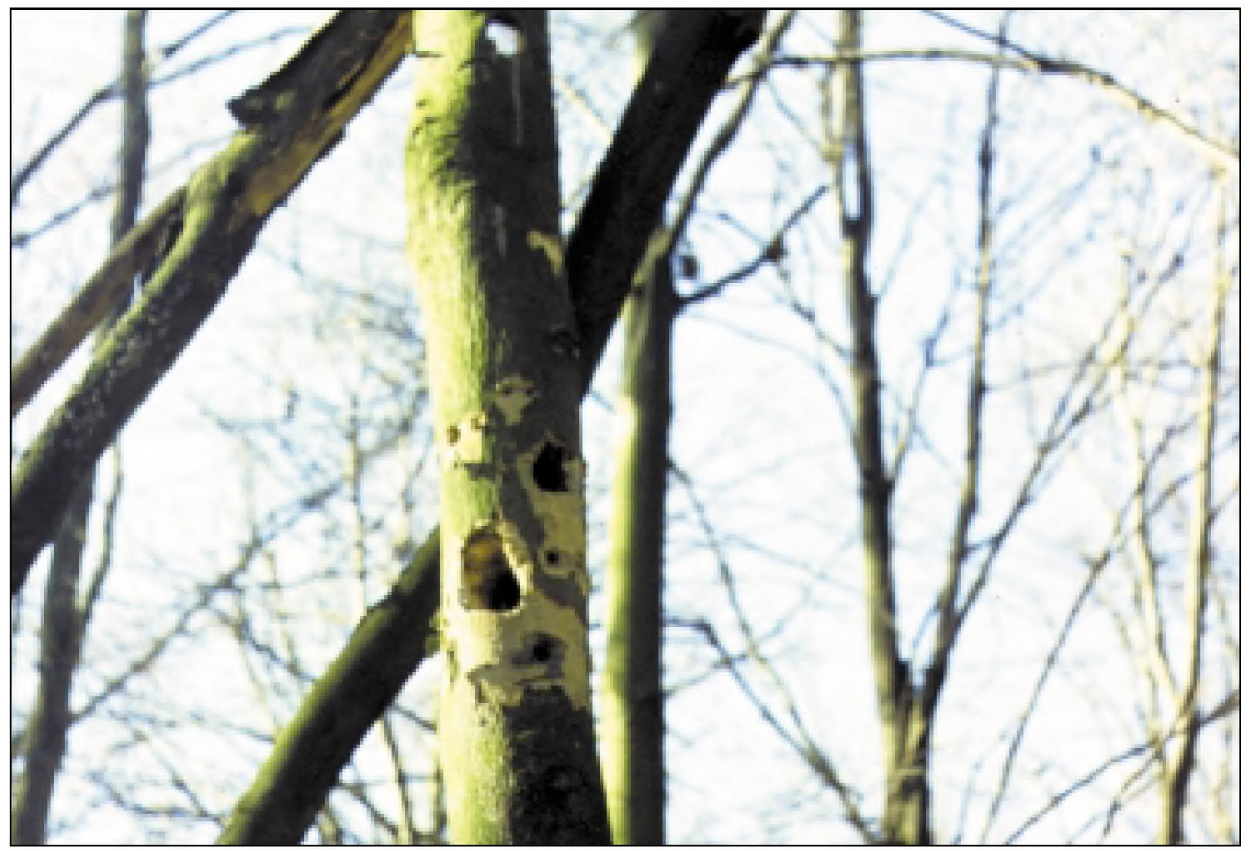

42. ábra: A nyest a fészkét fák odvában is kialakíthatja 


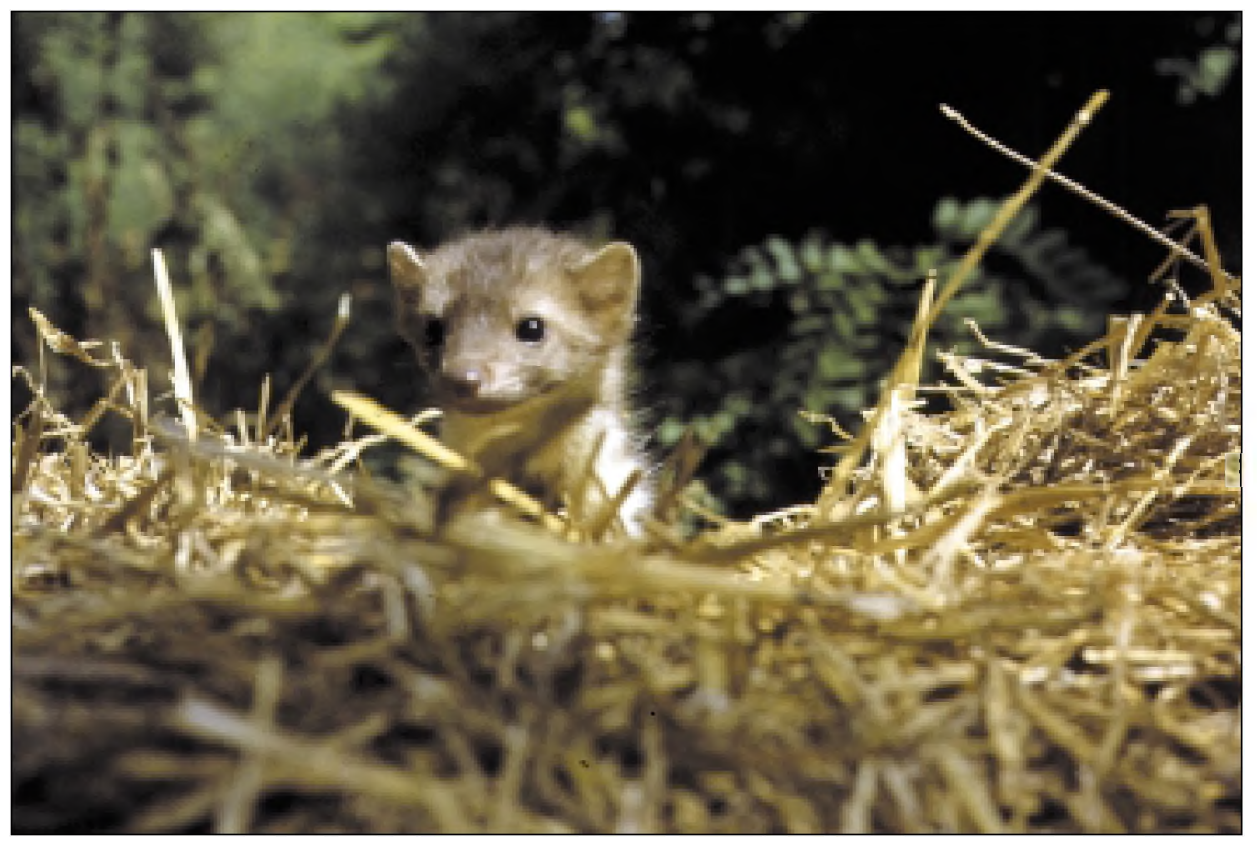

43. ábra: Nyestkölyök

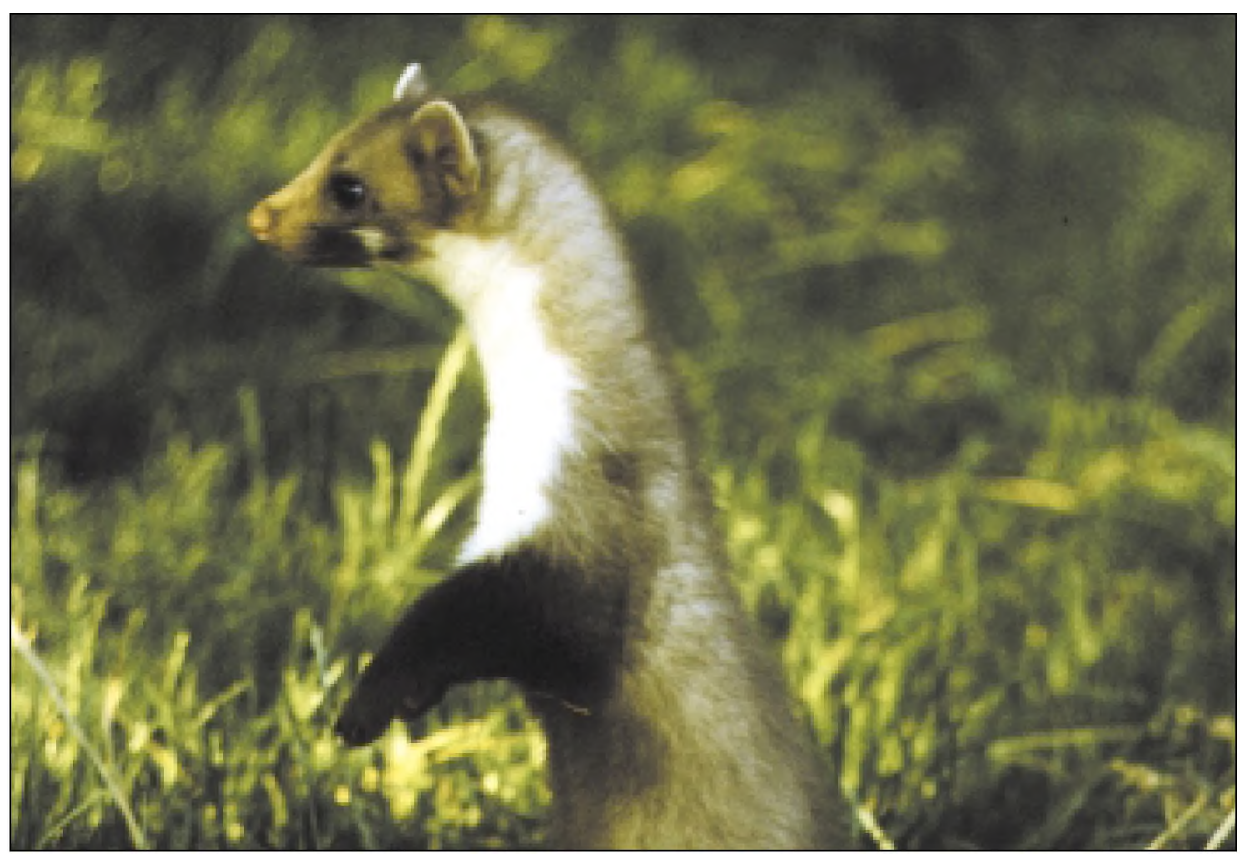

44. ábra: Figyeló nyest jellegzetes pózban 
A nyest legjelentősebb táplálékát éves összesítésben a növények, ezek közül is a kerti és vadon termó gyümölcsök jelentik, melyek vitamin és szénhidrát forrásként fontosak (PANDOLFI et al. 1996). A ragadozók fontos szerepet töltenek be a magvak szétterjesztésében (HERRERA 1989), mely révén - idővel - a saját táplálékkínálatuk is bővül. A nyest télen is folyamatosan aktív, növényeket (DELIBES 1978, PANDOLFI et al 1996) és potenciális táplálékforrásnak minősülő háziállatokat, illetve állatvágási maradékokat fogyaszt (pl. Holisová és OBRTEL 1982, RaSMUSSEN és MADSEN 1985, TótH-APÁTHY 1998). Nyáron és ősszel részben gyümölcsfogyasztás érdekében jár be a lakott területre. A nyári párosodási időszakban (MADSEN és RASMUSSEN 1985) gyakoribbá válik a territórium birtoklását jelző ürülékek (és vizelet) elhelyezésének gyakorisága a különböző tereptárgyakon, pl. köveken, fücsomón (SEILER et al. 1994), ekkor a nyest nappal is sokat mozog (Posillico et al. 1995). A vizuális és szagjelek elsősorban az azonos ivar távoltartását szolgálják, de az aktuális szaporodásbiológiai állapotot is jelzik (MACDONALD 1980), ami a különböző élóhelyek egyedeinek egyaránt jelzésként szolgálhat.

Más vizsgálatokhoz hasonlóan (pl. RASMUSSEN és MADSEN 1985, LUCERINI és CREMA 1993, TóTH-AРÁTHY 1998), a szemétből származó emészthetetlen, pl. múanyag és gumi alapanyagú termékek fogyasztása tekintetében a különböző környezetben élő egyedek között nagy különbség tapasztalható. Elófordulásuk azt jelzi, hogy a különbözó élóhelyeken éló nyestek közös táplálkozó helyeket is használnak.

Mezőgazdasági környezetben 350-400 ha territóriumot tartanak fenn a nyestek (SERAFINI és LovaRi 1993), a hímek kétszer nagyobb területet birtokolnak, mint a nöstények (Posillico et al. 1995). Más vizsgálatokban tapasztaltakhoz hasonlóan (DELIBEs 1978, RASMUSSEN és MADSEN 1985, GosZCZYNSKi 1986, SERAFINi és Lovari 1993), ilyen élőhelyen a talajszinten éló kisemlósök jelentik a legfontosabb zsákmányforrást. Házi egér és vándorpatkány szerepel ugyan a táplálékukban, de kisebb arányban, mint az urbánus környezetben élő nyesteknél. Az urbánus nyestek számára pedig nagyobb tápláléksürüség és könnyebben megszerezhető táplálék fajok állnak rendelkezésre, pl. háziállatok, galamb, házi egér, veréb, stb. (HoLISOVÁ és OBRTEL 1982, RASMUSSEN és MADSEN 1985, LuCERINi és Crema 1993, Sidorovich 1997, TótH-ApÁtHY 1998), melyek fö zsákmányukat képezik. A rendelkezésre álló táplálék-készlet minőségi és mennyiségi különbözősége és a nyestek kiváló alkalmazkodóképessége járulhat hozzá, hogy az urbánus nyestek a jellemzô 15-50 g súlykategóriába eső prédán kívül nagyobb zsákmányt is gyakran ejtenek. A nagyobb súlyú zsákmány (pl. csibe, galamb, tyúktojás) fészekbe vagy táplálkozó helyre cipelése a nyestnek nem okoz nehézséget. Bár jellemzóen talajszint közelében vadásznak, az urbánus nyestek gyakrabban fogyasztottak fákon, bokrokon, eresz alatt élő prédát is.

Nagy különbség tapasztalható a közös táplálékforrást jelentő háziállatok fogyasztása tekintetében a mezőgazdasági és az urbánus környezetben élő nyestek között. Az utóbbiak háromszoros mennyiségben fogyasztanak háziállatot, melyek közül legjelentősebbek a baromfifélék. A baromfifélék fogyasztott biomasszája hasonló a kistestú madarakéhoz vagy a házi egéréhez.

A kompetítor fajok jelenléte is befolyásolja a nyestek előfordulását, állománysürüségét és táplálékválasztását. Emberi településeken lényegesen kevesebb kompetítorral kell a forrásokat felosztani (Holisová és OBRTEL 1982, LuCERINI és CrEMA 1993). A nyest urbanizálódó viselkedése nagyon hasonlít a vörösrókához (pl. DONCASTER et al. 1990, MiTCHELL-JONES et al. 1999), a két faj között a természetes környezetben jelentős kompetíció tapasztalható (SERAFINI és LovARI 1993, BRANGI 1995). A lakott területeken is élő nyesthez hasonló táplálék-összetételú közönséges görény (összefoglalta: BLANDFORD 1987) lényegesen ritkább faj, mint a nyest; a két faj közötti kompetíció mértéke nem ismert. A nyuszt élőhely igénye, táplálkozási szintje és tápláléka általában eltér a nyestétől (pl. MitcheLL-JoNEs et al. 1999), bár alkatilag közel állnak egymáshoz. Földrajzi el- 
terjedésük nagy átfedést mutat és együttesen is elófordulhatnak adott területen (GosZCZYNSKI 1977, PEDRINI et al. 1995). A nyesttel való találkozást a kompetítornak tekinthetó házimacskák általában elkerülik. Esetenként azonban elöfordul, hogy a nyest valószínủleg - kölyökmacskát ejt zsákmányul (TóTH-AРÁTHY 1998), amint a jelen vizsgálatban is elófordult. Az urbanizálódott és a lakott területen kívül élö nyestek tényleges közös territórium használatára, valamint populációdinamikájuk vizsgálatára költségesebb módszerek alkalmazása (pl. rádio-telemetria: HERRMANN 1994, SEILER et al. 1994, Posillico et al. 1995, és/vagy genetikai vizsgálat: DALLAs et al. 1999, 2000) szolgálhat további ismeretekkel.

A vizsgálat nem adhat választ arra, hogy a természetes környezetben született nyestek életük során urbánus nyestté válhatnak-e, vagy fordítva. Azonban az alapvetően különböző élőhelyhez kötődő nyestek egyaránt változatos és részben közös táplálékforrásokat hasznosítanak. A különböző élöhelyhez kötődő egyedek az egymás mellett élés érdekében a forrásokat térben és időben felosztják. A mezőgazdasági és az urbánus környezetben élő nyestek egyaránt fogyasztanak emberi településekhez kötôdő táplálékot, pl. háziállatokat és kertben termő gyümölcsöket, valamint vadon élő állatokat is. Ezek az eredmények azt jelzik, hogy adott térség nyestpopulációjának egyedei nem különülnek el élesen térben, legfeljebb időszakosan.

Összességében megállapítható, hogy a különböző élőhelyeken előforduló nyestek közös táplálékforrásokat is hasznosítanak. Ragadozó életmódjuk ellenére éves szinten leggyakrabban fogyasztott táplálékukat a különbözô gyümölcsök jelentik. A növényi táplálék fogyasztásában azonban jelentós évszakos ingadozás tapasztalható. A préda fajok közül a mezőgazdasági környezetben élő nyestnél a kisemlősök, az urbánus nyestnél a madarak a legjelentősebbek. A háziállatok (föként baromfifélék) fogyasztásban a nyestek jellemző élőhelyétől függően lényegesen különbség tapasztalható. A táplálkozási niche szegregálódásban szerepet játszik, hogy a mezőgazdasági környezetben élő nyesteknél a fogyasztott préda gyakrabban kisebb súlyú, talajszinten élö, valamint kötődését tekintve jellemzően vadon élö, ellentétben az urbánus nyestekkel.

A nyest kutatásával kapcsolatos további részletek az alábbi sorszámú publikációkban találhatók meg: $[1,2,4,6,12,13,14,15,17,18,23,25,31]$. 


\section{A nyuszt}

A nyuszt eurázsiai elterjedésủ faj. Európában Skandinávia északi területeitől egészen a déli országokig előfordul, de Dél-Európában lényegesen ritkább faj. Nagyon hasonlít a nyesthez, de fülei kissé nagyobbak, torokfoltja általában krémszínú, melynek alakja lekerekített, szemben a nyesttel, melynek fehér torokfoltja villásan elágazik és egészen a mellső lábakra lehúzódik. Élőhelyeit elsősorban erdők jelentik, melyek egyaránt lehetnek lombhullató és fenyóerdők, továbbá előfordulhat cserjékkel borított területeken is. A szaporodó egyedek kerülik a fátlan vegetációt, kedvelik a dús aljnövényzetű erdőt, ahol a rágcsálósürúség is nagyobb (MiTCHELL-JoNES et al. 1998).

A nyuszt tehát tipikus erdei ragadozó, táplálkozási szokásait tekintve generalista. Leggyakrabban rágcsálók, köztük mókus, továbbá rovarevő emlősök, madarak, gyümölcsök és döghús alkotja a skandináviai nyusztok táplálékát (PULLIAINEN 1980, 1982, Pulliannen és Ollinmäki 1996, Helldin 2000). A svájci Alpokban (MARCHESi és MERMOD 1989), a skóciai (LockIE 1961), a lengyelországi (GosZCZYNSKI 1986, JEDRZEJEWSKI et al. 1989, 1993b) erdőkben, valamint mediterrán szigeteken (MoRENo et al. 1988, Clevenger 1993a, 1993b) is hasonló táplálékon élnek a nyusztok, de az arányok eltérnek, köszönhetően annak, hogy talajszinten és a fák lombkoronájában is sikeres vadász. A nyuszt fontos predátora a kisrágesálóknak (GosZCZYNSKI 1977), a madaraknak és a mókusnak (JEDRZEJEWSKA és JEDRZEJEWSKI 1998). Táplálék-összetétele viszonylag jól ismert a külföldi leírásokból. Magyarországon végzett vizsgálatok hiányában a hazai környezeti feltételekhez hasonló körülmények között kapott eredmények közül emelek ki néhányat. Lengyelországban, a Bialowieza-i Nemzeti Parkban végzett vizsgálatban a nyuszt biomassza számítás szerinti legfontosabb táplálékát a rágcsálók alkották (50-90\%). A zsákmányejtésnek júniusban volt a minimuma és októberben a maximuma (JEDRZEJEWSKI et al. 1993b). A madarak aránya tavasszal és nyáron volt magas, júniusban elérte a 37\%-ot. A növényi táplálék júliustól októberig játszott fontos szerepet. Előnyben részesítették a farkas és hiúz által elejtett prédák maradványait is, de elkerülték a betegség, illetve alultápláltság miatt elpusztult nagyvadak tetemeit. A zsákmányszerző magatartás az esetek többségében (90\%-ban) rágcsálókra irányult, gyakoriságát tekintve négy zsákmányállat $/ \mathrm{km}$ és az eseteknek 35\%-ában volt sikeres (JEDRZEJEWSKI et al. 1993b). Rádio-telemetriás vizsgálattal megállapították (ZALEWSKI 1997a), hogy egy év alatt, ivartól függően, 150-200 különböző pihenőhelyet használnak a nyusztok. A pihenóhelyek újbóli használata gyakoribb volt, amikor nagyvad tetemekre jártak vissza és ritkább havas, illetve hideg időben. A pihenóhelyek újbóli használatának gyakorisága független volt a rágcsálósűrűségtől. A nyári (párosodási) időszakban a hímek és a nőstények egymáshoz közel választottak pihenőhelyet. A két egymást követő pihenőhely közötti távolság a hímeknél hosszabb volt, mint a nőstényeknél (690, ill. 419 m). A nyuszt gyakrabban használt pihenőhelynek üregeket (talaj közelben, vagy odvas fákban), mint madárfészkeket (ZALEWSKI 1997b). A hímek gyakran, a kölyköt nevelö nőstények kizárólag odvas fákat használtak, de a nem kölykes nóstények jórészt fészkekben pihentek. A hömérséklet is hatást gyakorolt a pihenőhely választásra, alacsonyabb hömérsékleten gyakrabban pihentek talajhoz közeli üregekben, vagy odvas fákban. A földön levô pihenóhelyet (vagy odvas fát) gyakrabban választottak csapadékos időjárás, vagy magas hó 
borítás esetén (ZALEWSKI 1997b). A fent említett területen téli nyomszámlálás módszerrel a nyuszt sürüsége évtôl függóen 4,44 és 6,49 egyed/10 $\mathrm{km}^{2}$ között változott (ZALEWSKI et al. 1995). A rádióadóval ellátott hímivarú, illetve nóivarú nyusztok átlagos mozgáskörzete 2,23 , illetve $1,49 \mathrm{~km}^{2}$ volt. A mozgáskörzet kiterjedése őszi-téli időszakban egyharmaddal kisebb volt, mint az év többi részében. A nyuszt föként éjszaka és szürkületben jár tápláléka után, mely fóként erdei pocokból és sárganyakú erdeiegérből áll. A nőstények korábban indulnak vadászni, mint a hímek, de mindkét ivarra jellemző, hogy a vadászatról napkelte után másfél órával térnek a pihenőhelyre (ZALEWSKI 2000, 2001).

A nyuszt előfordulhat a nyesttel, a vörösrókával, a borzzal és más predátorokkal is a ragadozók életközösségében (GOSZCZYNSKI 1977, STORCH et al. 1990, CLEVENGER 1994, Pedrini et al. 1995, Sidorovich 1997, Kurki et al. 1998, Mitchell-Jones et al. 1998), de a ragadozók interspecifikus kapcsolatai alig ismertek.

\section{A nyuszt táplálék-összetétele}

A Boronka-melléki Tájvédelmi Körzetben, valamint a Lankóci-erdöben élố nyusztok táplálékának előfordulási gyakoriság és biomassza számítás szerinti évszakos táplálékösszetételét a 48, ábra és a 12. melléklet tartalmazza. A nyuszt jellemzően lombkorona szintben megfigyelhetó ragadozó emlős (ZALEWSKI 1997a, b), ebböl adódóan madárfogyasztását gyakran túlértékelik. Az adatokból látható, hogy a nyuszt elsődlegesen fontos zsákmány csoportját mindkét vizsgált területen és minden évszakban a kisemlósök jelentették. Ezek közül a talajszinten éló erdei pocok szerepe volt minden esetben meghatározó. Ezért is nevezte JEDRZEJEWSKA és JEDRZEJEWSKI (1998) a nyusztot erdei pocok specialistának.

A Boronka-melléki Tájvédelmi Körzetben élő nyuszt táplálékának felét ősztől tavaszig kisemlösök (49-56\%) alkották, mindössze nyáron volt alacsonyabb (27\%) fogyasztott biomasszájuk aránya (48. ábra és a 12. melléklet). A nagy kiterjedésú erdővel közrezárt tavak körül élő nyuszt szinte kizárólag erdei fajokat fogyasztott: az erdei pockon kívül jelentôs volt az erdeiegér fajok részaránya is. Továbbá előfordultak a táplálékban cickány és pele fajok (télen, valószínúleg nyugalmi időszakban), valamint mókus is. A vizsgálatban szereplő tavakhoz és erdőterületekhez legközelebbi mezőgazdasági területek kb. 1,5 km távolságra találhatók. Ennek megfelelốen a mezei pocok előfordulási gyakorisága még a téli relatíve táplálékszegény, valamint a tavaszi időszakban is egy százalék alatt maradt. Mezei nyúl csak a nyári időszakban szerepelt táplálékként (biomasszája $0,1 \%$ ).

Az elhullott csülkös vadak (fóként vaddisznó) fogyasztása télen kiugróan nagy arányú volt (30\%), majd őszig drasztikusan visszaesett (48. ábra és a 12. melléklet). A nagyvadak gyakori táplálékként való előfordulása a vadászatok során sebzett egyedek tetemeiből való fogyasztással magyarázható. Nyári és őszi idốszakban, a táplálékban ritkán és alacsony biomassza részesedéssel $(0,3-0,8 \%)$ fordultak elö.

A madarak fogyasztása tavaszi időszakban volt kiemelkedóen magas (biomasszája $27 \%$ ), és egészen a téli hónapokig ( $8 \%$ ) fokozatosan csökkent (48. ábra és a 12. melléklet). A táplálék döntő többségét kistestü énekesmadarak képezték. Faj szerint a tengelicet, a csuszkát, az ökörszemet lehetett kimutatni, de elöfordultak táplálékként nagyobb testú, vizes élőhelyhez kötődő, pl. réce fajok is. Ebben az időszakban feltételezhető a könnyebben zsákmányul ejthető fészken ülő madarak, illetve a fiókák fogyasztása. Madártojás fogyasztás a tavaszi időszakban fordult elö, melynek biomasszája $0,3 \%$-ot tett ki.

A hüllő és a kétéltű fajok a telelés és a tavaszi nászidőszakban szerepeltek jelentősebb mennyiségben táplálékként (4\%). Arányuk nyáron és összel alacsony $(0,2-0,8 \%)$ szinten mozgott (48. ábra és a 12. melléklet). A táplálék fajok között vízisikló, gyíkok, tavi- és kecskebéka szerepelt.

A halak nem tipikus táplálékai a nyusztnak, de tekintve, hogy a tájvédelmi körzet ta- 


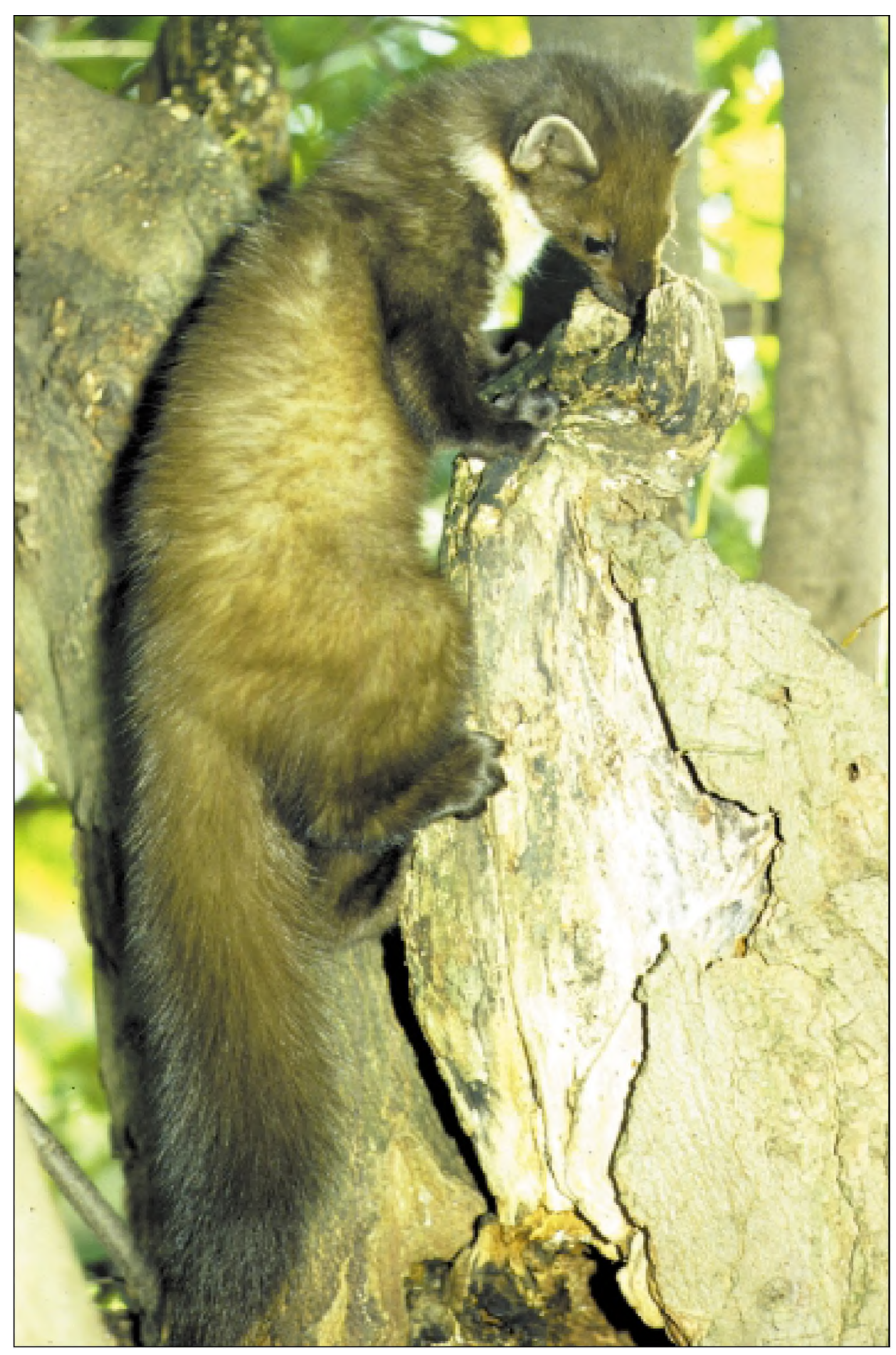

45. ábra: Nyuszt (Martes martes) 


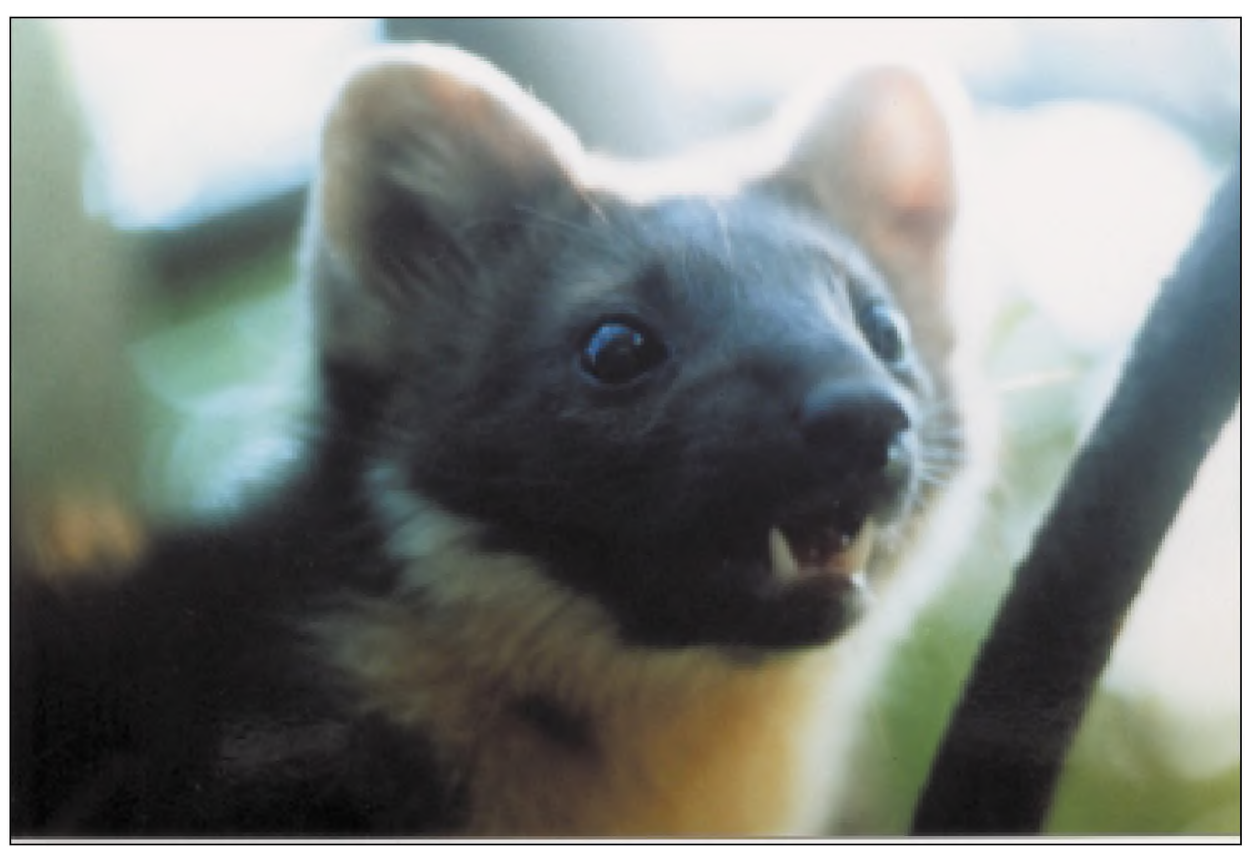

46. ábra: Nyuszt portré

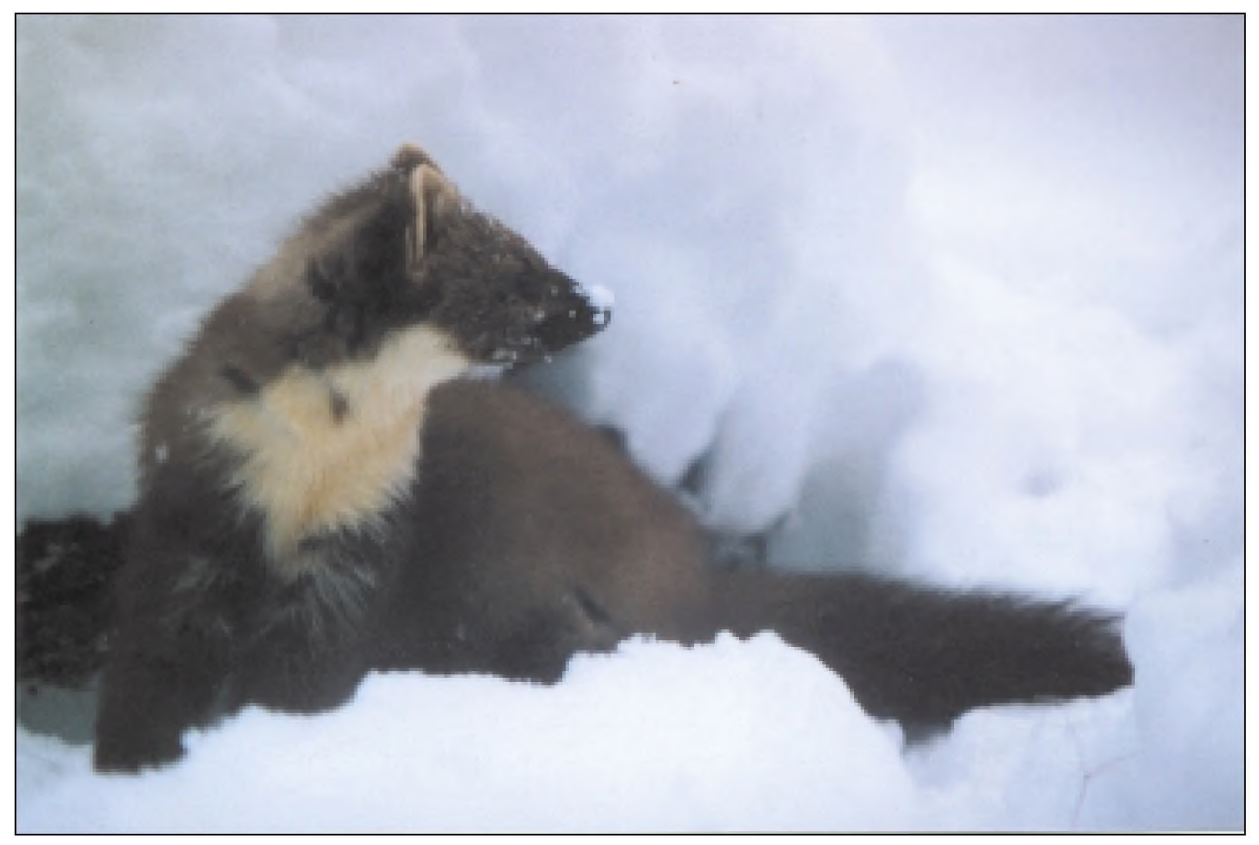

47. ábra: A nyuszt a hó alatt is megtalálja zsákmányát 
vain haltermelést folytatnak, a fogyasztott halak biomassza szerinti részesedése említést érdemel (48. ábra és a 12. melléklet). A nyuszt a tavaszi haltelepítés és az öszi lehalászás időszakában a parton hagyott, vagy elpusztulva part közelébe sodródott, valamint télen a jég alatt elpusztult halakból fogyaszthatott leginkább.

A gerinctelenek gyakori táplálékát képezték a nyusztnak, még a téli időszakban is (13\%). Tavasszal és nyáron az esetek harmadában, negyedében evett ízeltlábúakat (48. ábra és a 12. melléklet), bár biomassza számítás szerinti részarányuk ekkor is alacsony volt $(2,3 \%)$. A rovartáplálék nagy fajgazdagságot mutatott. Leggyakrabban futóbogarakkal táplálkozott a nyuszt, de táplálékában viszonylag gyakran szerepeltek galacsinhajtó bogarak és darazsak, valamint darázsfészek is. Ritkán vízhez kötő́dő fajokat, pl. sárgaszegélyú csíkbogarat, szitakötóket, tízlábú rákot, valamint szarvasbogarat és kis szarvasbogarat is fogyasztott .

A növényi táplálék igen fontos szerepet töltött be a nyuszt táplálkozásában, különösen nyáron és ősszel (48. ábra és a 12. melléklet). Nyári időszakban a táplálék fele (49\%), ősszel a harmada (32\%), elsősorban vadon termő gyümölcsökből állt. Bár növények télen és tavasszal is viszonylag gyakran szerepeltek táplálékként, biomasszájuk alacsony volt (3\%). A leggyakoribb növényi táplálék télen a vadetetőkről származó kukorica, tavasszal a vadon termő cseresznye, nyáron a cseresznye és a szeder, összel a vadkörte és a kökény volt.

A Lankóci-erdőben élő nyuszt évszakonkénti tápláléka döntő részben kisemlősökből

$\%$

\section{Boronka melléki Tájvédelmi Körzet}

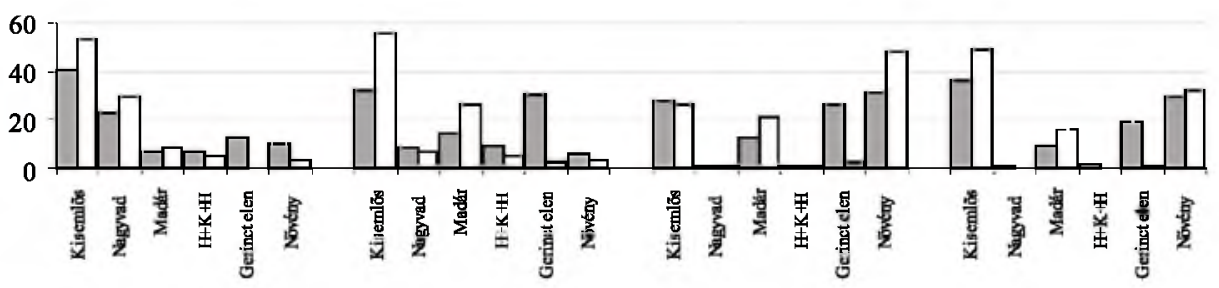

$\%$

\section{Lankóci-erdõ}

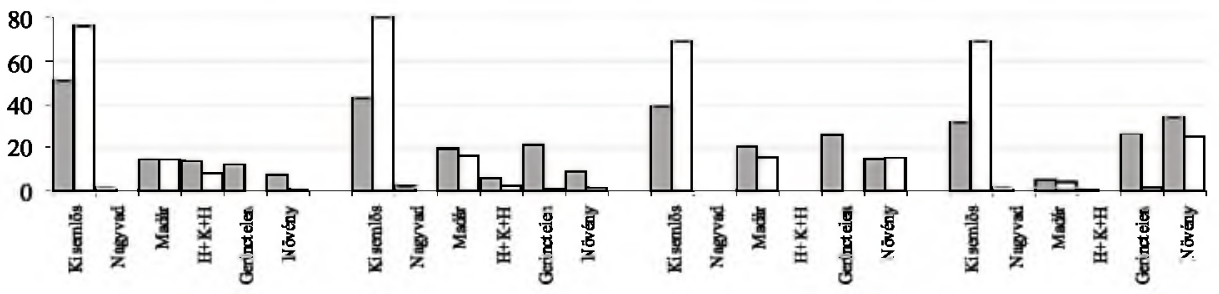

16. ábra: A nyuszt táplálék-összetétele két erdei élóhelyen

Megjegyzés: $\mathrm{H}+\mathrm{K}+\mathrm{H}=$ hülló, kétéltủ és hal együtt, tömör oszlop jelzi a relatív gyakoriságés üres oszlop a biomassza számítás alapján kapott értékeket 
állt, melyek biomassza számítás szerinti aránya viszonylag szük határok (69-80\%) között mozgott (48. ábra és a 12. melléklet). A táplálékként legfontosabb erdei pocok, valamint az erdei élóhelyeket előnyben részesítő pelefélék és erdeiegér fajok mellett, a környező mezőgazdasági területeken élő mezei pocok és más Microtus fajok szerepe is jelentôs volt. Mezei nyúl tavaszi időszakban fordult elô táplálékában (biomasszája 3\%).

A csülkös vadak fogyasztása minden évszakban alacsony $(0,1-0,3 \%)$ szinten mozgott.

A madarak a téli időszak kivételével kisebb arányban szerepeltek a nyuszt táplálékában, mint a Boronka-melléki Tájvédelmi Körzetben (48. ábra és a 12. melléklet). Zömmel kistestü énekesmadarakat fogyasztott, de előfordult táplálékként mátyásmadár és harkály is. A nyuszt a tavaszi idószakban zsákmányolt tojást, melynek biomasszája a táplálékban $0,9 \%$-ot tett ki.

Hüllőket és kétéltüeket leggyakrabban télen fogyasztott. Ekkor a békák szerepe volt jelentôsebb, míg tavasszal a hüllök (siklófélék és gyíkok) váltak fontosabb táplálékká (48. ábra és a 12. melléklet). Összel csak alacsony arányban, nyáron pedig nem szerepeltek a nyuszt étlapján. Halak mindössze télen fordultak elö táplálékként.

A gerinctelenek gyakran szerepeltek a Lankóci-erdóben éló nyuszt táplálékában is (48. ábra és a 12 . melléklet). Biomassza számítás szerinti arányuk viszont alacsony szinten mozgott (0,3-2\%), ősszel volt a legnagyobb arányú a fogyasztásuk. A fóként rovarokból álló táplálék változatos képet mutatott, leggyakrabban futóbogarak és galacsinhajtó bogarak szerepeltek benne.

A Lankóci-erdôben élő nyuszt táplálékában a növények szerepe lényegesen kisebb volt, mint a Boronka-melléki Tájvédelmi Körzetben. Biomassza számítás szerinti arányuk nyáron $15 \%$ és ősszel $25 \%$ volt. A legfontosabb növényi táplálék télen a kökény és a csipkebogyó, tavasszal a vadon termố cseresznye, nyáron a körte és a szeder, összel a körte volt.

A nyusztok nem fogyasztottak háziállatot.

A két különböző erdei élőhelyen vizsgált nyusztok tápláléka statisztikailag nem tért el lényegesen sem a téli-tavaszi $(\mathrm{P}=0,454)$, sem a nyári-ôszi $(\mathrm{P}=0,440)$ időszakban.

\section{Preferencia számítás}

A Boronka-melléki Tájvédelmi Körzetben a három éves idôttartamban végzett kisemlős elevenfogó csapdázási adatokat évszakonként összevontam a preferencia számítás elvégzéséhez. A vizsgált terület kisemlős táplálék-forrásának alakulását a 17. ábra szemlélteti.

\section{A kisemlös táplálék-készlet}

A területen a kisemlős táplálékforrás mennyisége és fajösszetétele az évszakok és az évek között is változott (49 ábra). Az őszi időszakban tapasztalt maximális biomassza, a tél során fokozatosan csökkent és tavasszal, a rágcsálók szaporodásának kezdetén érte el mélypontját. A vizsgált területen 1999-ben éltek a legnagyobb mennyiségben és létszámban kisemlösök. Az 1999/2000-es enyhe télnek köszönhetóen, nagy arányú volt a téli túlélésük is. Ennek ellenére a 2000 -es évben nem volt tapasztalható kiugróan magas kisemlös sürüség (49. ábra). Az első időszakban az erdei pocok dominált a kisemlős életközösségben. A második időszakban az erdei pocok és az erdei egerek elófordulási gyakorisága közel megegyezett (49c. ábra). A harmadik időszakban az eredi egerek domináltak a potencionális kisemlós táplálékforrásban. 

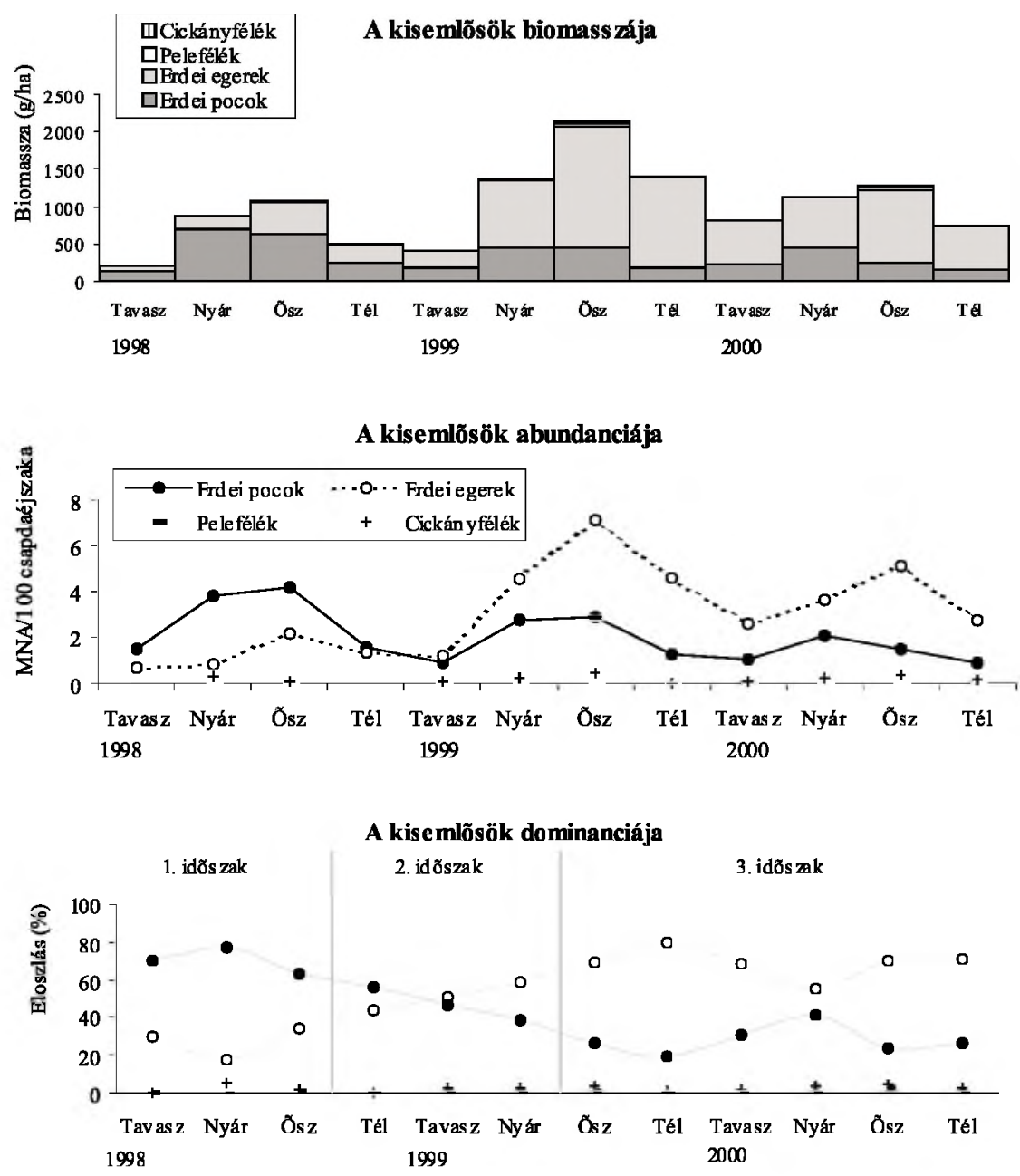

49. ábra: A kisemlős táplálék-forrás alakulása a Boronka-melléki Tájvédelmi Körzetben Megjegyzés: MNA = minimum ismert egyedszám

\section{A nyuszt kisemlös preferenciája}

A nyuszt évenkénti és azon belül évszakonkénti kisemlôs tápláléka, valamint a kisemlős táplálék-készlet azonos időszakra vonatkozó értékei képezték a kisemlős-preferencia számítás alapját. A "preferencia" azt jelenti, hogy a nyuszt az adott táplálék fajt vagy taxont nagyobb gyakorisággal fogyasztja, mint ahogy az a táplálék-forrásban rendelkezésre áll. A vadászat során a keresés "mellőzése" (negatív preferencia) pedig azt jelzi, hogy adott fajt vagy taxont kisebb arányban fogyasztja, mint az a készletben rendelkezésre áll, vagyis más táplálékot részesít elónyben. A 50. ábrán a kisemlős táplálék-készletben legjelentósebb erdei pocok és erdei egér faj-együttes évszakonkénti Ivlev-féle preferencia indexei $\left(E_{j}\right)$ láthatók. A vizsgálat első két időszakában (évében), amikor a kisemlős életközösségen belül az erdei pocok szerepe meghatározó volt, vagy jelentősége az erdeiegér fajokhoz hasonlóan alakult (49. ábra), a nyuszt zsákmányszerzése során kis- 
mértékben mellőzte, majd a vizsgálat harmadik időszakában jelentős mértékben preferálta az erdei pockot.

Az erdei egereket az első időszakban kismértékben preferálta, majd a második és harmadik időszakban kismértékben mellözte. A nyuszt az erdei pockot elsősorban télen és összel, az erdei egér fajokat nyáron részesítette elönyben $(\mathrm{P}<0,05)$.

A három vizsgált év átlagában megállapítható, hogy a nyuszt az erdei pockot kismértékben preferálta $\left(E_{i}=0,10\right)$, az erdei egereket kismértékben mellözte $\left(E_{i}=-0,14\right)$, továbbá a peleféléket kismértékben preferálta $\left(\mathrm{E}_{\mathrm{i}}=0,16\right)$, a cickányféléket pedig előfordulási gyakoriságuknál ritkábban fogyasztotta $\left(\mathrm{E}_{\mathrm{i}}=-0,28\right)$.

A nyuszt préda fajainak súlya és jellemzö élóhelye

Erdei pocok

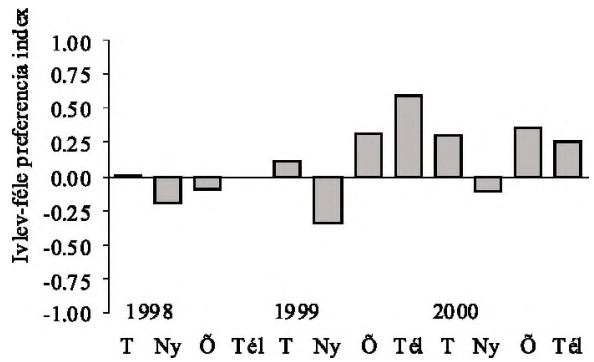

Erdeiegér fajegyüttes

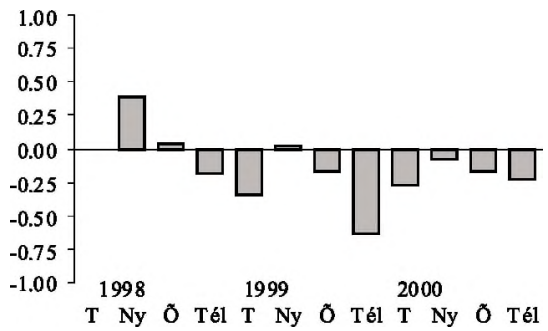

50. ábra: A nyuszt kisemlős preferenciája* a Boronka-melléki Tájvédelmi Körzetben Megjegyzés: * előfordulási gyakorisági adatokon alapuló számítás szerint; évszakok rövidítése: $\mathrm{T}=$ tavasz, $\mathrm{Ny}=$ nyár, $\mathrm{O}=$ ősz

A Boronka-melléki Tájvédelmi Körzetben és a Lankóci-erdóben élő nyusztok egyaránt a 15 és $50 \mathrm{~g}$ közötti súlyú prédát fogyasztották leggyakrabban (56, illetve $60 \%, 51$. ábra). Emellett a $15 \mathrm{~g}$ alatti préda fajok gyakorisága is jelentős volt (31, ill. 35\%). A nagyobb súlykategóriákba tartozó prédák általában nem játszottak fontos szerepet a táplálkozásban. Ez alól kivételt jelent a $300 \mathrm{~g}$ feletti súlytartomány a Boronka-melléki Tájvédelmi Körzetben, ahol az elhullott nagyvadak téli fogyasztása miatt az előfordulási gyakoriság számottevő volt $(9 \%)$.

Az erdőkben élő, kiváló mászóképességgel rendelkező nyuszt táplálékát mindkét élöhelyen elsősorban talajszinten szerezte meg. A Boronka-melléki Tájvédelmi Körzetben a préda fajok $81 \%$-a, a Lankóci-erdőben $71 \%$-a jellemzően talajszinten élt. A zsákmány fajok 17, illetve 29\%-ának elöfordulása köthető jellemzően bokor-, vagy lombkorona szinthez, és mindössze 3-5\%-a kötődött vizes élőhelyhez (51. ábra).

\section{A nyuszt táplálkozási niche-szélessége}

A táplálék változatosságából és a táplálék taxonok egymáshoz viszonyított kiegyenlített arányaiból adódóan mindkét élőhelyen hasonlóan széles volt a nyusztok táplálkozási niche-e (52. ábra). A Boronka-melléki Tájvédelmi Körzetben a táplálkozási niche-szélesség a téli-tavaszi időszakban 6,69, a nyári idôszakban 5,35 és a Lankóci-erdôben 6,09 , illetve 4,81 volt.

Összességében megállapítható, hogy nyuszt elsődlegesen fontos tápláléka kisemlő- 


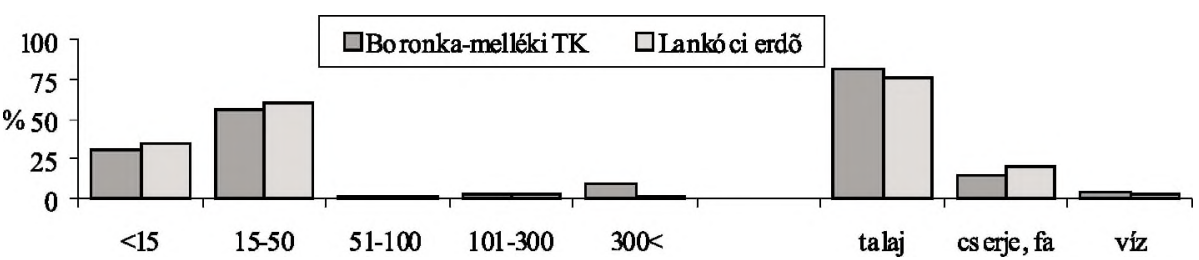

51. ábra: A nyuszt prédaválasztása a zsákmány súlya és jellemző élőhelye szerint

sökböl áll, arányuk különösen a téli és a tavaszi időszakban nagy. A legfontosabb táplálék faj az erdei pocok, emellett az erdeiegér fajok fordulnak eló gyakran. A Boronkamelléki Tájvédelmi Körzetben végzett vizsgálat alapján a nyuszt az erdei pockot kismértékben elônyben részesíti zsákmányszerzése során, az erdei egereket pedig elófordulási gyakoriságuknál kisebb mértékben zsákmányolja. A táplálékválasztást azonban a kisemlôs táplálék-készlet összetétele is befolyásolja. A nyuszt táplálékában a madarak a nyári és az őszi időszakban másodlagosan fontos szerepet töltenek be. A madártáplálékot zömmel kistestú énekesmadarak alkotják. Gerinctelenek gyakran fordulnak elő a táplálékban, ezek biomasszája viszont elenyészóen alacsony. A többi táplálék taxon szerepe élöhelytől függően lényegesen különbözik. Például téli időszakban jelentős mennyiségben fogyaszthat elhullott nagyvadakból, vagy halastavak közelében halat. A növények szerepe élő́helytől függően szintén lényegesen különbözhet. Nyári időszakban akár a nyuszt domináns táplálékát is alkothatják a különböző vadon termő gyümölcsök, szerepük ősszel szintén jelentős. A nyuszt tápláléka igen változatos, fajokban gazdag, táplálkozási niche-e minden évszakban széles. Zsákmányának döntő hányadát apró, $50 \mathrm{~g}$ alatti állatok alkotják. Annak ellenére, hogy kiváló famászó, préda fajainak zöme talajszinten él, viszonylag ritkán zsákmányol fákon és bokrokon élő fajokat.

A nyuszt kutatásával kapcsolatos további részletek az alábbi sorszámú publikációkban találhatók meg: $[13,14,20,23,30]$. 
Boronka-melléki TK

Lankóci-erdó

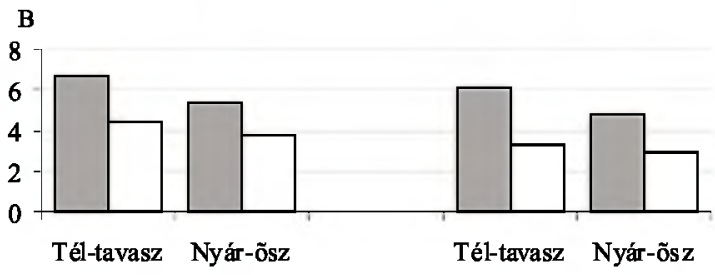

52. ábra: A nyuszt táplálkozási niche-szélessége különböző élőhelyeken

Megjegyzés: tömör oszlop jelzi a relatív gyakoriság- és üres oszlop

a biomassza számítás alapján kapott értékeket. 


\begin{abstract}
A borz
A borz Európa legtöbb vidékén megtalálható a sarkkörtől a mediterrán területekig, ezen kívül Ázsiában is honos. Élőhelyét lomberdők és fenyővel vegyes állományú erdők, sövények, cserjések, folyópartok, mezőgazdasági, külvárosi és városi parkok egyaránt jelenthetik, ahol a talaj alkalmas kotorék készítésére. Magashegyvidéken 1600$1700 \mathrm{~m}$-ig elöfordulhat. Állománysürüsége a Cseh Köztársaságban és Szlovákiában 0,10,6, Lengyelországban 0,7 , Hollandiában 1,0, Svédországban 2,4-3,2, Németország keleti területén 2,0-4,0, Skóciában 1,1-6,2, Angliában 4,7-19,7, Franciaországban 0,5-1,6 kifejlett egyed $/ \mathrm{km}^{2}$. Nagy egyedsürüség esetén elöfordulhat (csemege)kukoricában és gyümölcsösökben okozott kártétele. Továbbá szántóföldön ásott kotoréka veszélyes lehet a mezőgazdasági gépekre, a gátakba fúrt járatai pedig árvízvédelmi problémát okozhatnak. A TBC terjesztésében is szerepe lehet (MITCHELL-JONES et al. 1998). Élöhelyeinek nagy változatossága szorosan összefügg táplálkozási szokásainak nagyfokú plaszticitásával. A fejlett szociális magatartást mutató borz életmódját több tanulmány is részletesen ismerteti (pl. Cheeseman et al. 1988, KruUk 1989, NeEl és CheESEMAN 1996).

A borz táplálék-összetételét Európa és Ázsia számos területén, a legkülönfélébb klimatikus adottságú élöhelyeken tanulmányozták. Táplálékában gyürüsférgeket, talajszinten éló rovarokat, gyümölcsöket, gabonaféléket, kisemlösöket, vagy kétéltúeket találtak (pl. KruUK és Parish 1981, Ciampalin és Lovari 1985, LüPs et al. 1987, KruUK 1989, PIGOZZI 1988, 1991 GoszCZYNSKI et al. 2000). A legtöbb területen a földigiliszta fogyasztása kiemelkedően nagyarányú, azonban a borz táplálék-összetétele a különböző adottságú élöhelyek jellegétől függően változik (pl. PIGOZZI 1988, KRUUK 1989, GoszCZYNSKI et al. 2000). Széles elterjedése mutatja, hogy a borz az egyik legjobb alkalmazkodóképességgel rendelkező ragadozó emlős. A nagyszámú és szerteágazó táplálkozás-ökológiai kutatás közül a hazai környezeti feltételekhez leginkább hasonló lengyelországi eredményeket ismertetem röviden. A vizsgálatok (GosZCZYNSKI et al. 2000) természetes állapotú (ős)erdőben, valamint erdővel mozaikos mezőgazdasági területeken zajlottak. Tavaszi idöszakban, élöhelytőll függetlenül a borz táplálékának 82-89\%-át földigiliszta alkotta, biomassza számítás alapján. Nyáron és összel ezek aránya 56\%-ra csökkent az erdőben és 24\%-ra a mezögazdasági területen. Ekkor a borz fontos táplálékát kétéltúek (az erdöben) és gyümölcsök alkották (a mezögazdasági területen). A szerzők az európai irodalom feldolgozása alapján megállapították, hogy a borz táplálékában a földigiliszta szerepe a 37-40. földraizi szélességi fokon kapott nulla értékról az 55-63. szélességi fokig 40-70\%-ra emelkedik. Ezzel fordított trend figyelhetó meg a növényfogyasztásban. A gerincesek az északi vidékeken, a gerinctelenek a déli területeken fordulnak elő nagy gyakorisággal borz táplálékként.
\end{abstract}

\title{
A borz táplálék-összetétele erdei és mezögazdasági területen
}

A borzra jellemző, hogy ürítőhelyeinek döntő többségét a földbe ásott járata vagy vára közelében alakítja ki, és egy-egy földbe kapart kis gödröt több alkalommal is használ. Emellett éjszakai, szürkületi útjai során bizonyos pontokat is kijelöl ürítésre, mellyel egyben területét jelzi. A Boronka-melléki Tájvédelmi Körzetben a mintagyújjtés föként a 
halastavak közelében található borzvárnál, valamint a halastavak mentén vezető útvonalain talált ürítöhelyekröl történt. A Fonói tó körzetében a gyủijtés a halastó mellett fekvő erdőben található évtizedes borzvár közelében és a közlekedő utak melletti ürítô helyeken zajlott. A téli időszakban a mezőgazdasági területről nem állt rendelkezésre minta.

A Boronka-melléki Tájvédelmi Körzetben élö borz táplálékában a kisemlősök biomassza szerinti aránya téltől nyárig alacsony szinten mozgott (1-3\%), csak ősszel emelkedett meg (12\%) (53. ábra és 13. melléklet). A kisemlős fajok között legfontosabb az erdei pocok volt, és ritkán szerepeltek egérfélék és cickányfélék is. A táplálékként előforduló nyuszt és kutya, a szarvasfélékhez hasonlóan, valószínüleg dögfogyasztásból származhatott, de nem zárható ki zsákmányul ejtésük sem. Jelentôségük elenyészően kicsi volt $(0,8 \%$ alatt $)$.

Kistestü énekesmadarak fogyasztása a téli időszak kivételével egész évben előfordult. Madártojást tavasszal fogyasztott (53. ábra és 13. melléklet), biomasszája alacsony volt $(0,4 \%$ alatt $)$

Az erdővel övezett halastavak mentén élö borz elsődlegesen fontos táplálékát az év nagy részében, tavasztól ôszig, hüllök és kétéltűek alkották (53. ábra és 13. melléklet). Nyáron számottevő mértékben fogyasztotta a mocsári teknős (11\%) és a vízisikló (2\%) tojását. Ekkor a tavak töltései mentén gyakran lehetett borz és róka által szétkapart hüllô fészkeket találni. A kétéltúekből álló táplálék szerepe azonban a hüllóknél sokkal jelentősebb volt. A kétéltüek közül a borz legfontosabb táplálékát még téli időszakban is a kecskebéka jelentette, de emellett számos más békafajt is fogyasztott.

Halak csak télen és ôsszel fordultak elő az étlapján (53. ábra és 13. melléklet), de ezek nem tipikus táplálékai a borznak, jelentőségük is alacsony volt (biomasszájuk $0,1 \%$ ).

Tavasz

Nyár

Ósz

$\%$

\section{Boronka-melléki TK}

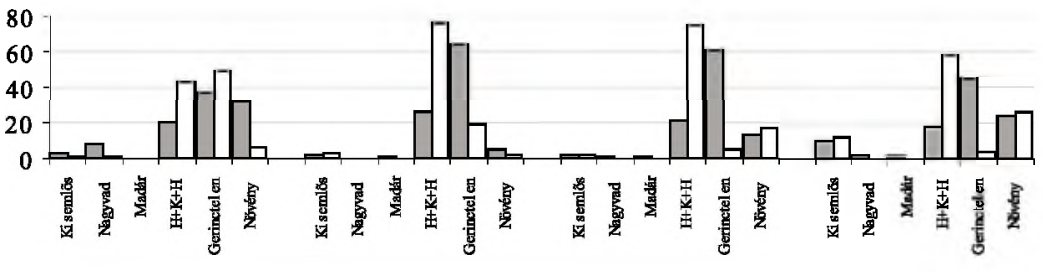

Tavasz

Nyár

Ösz

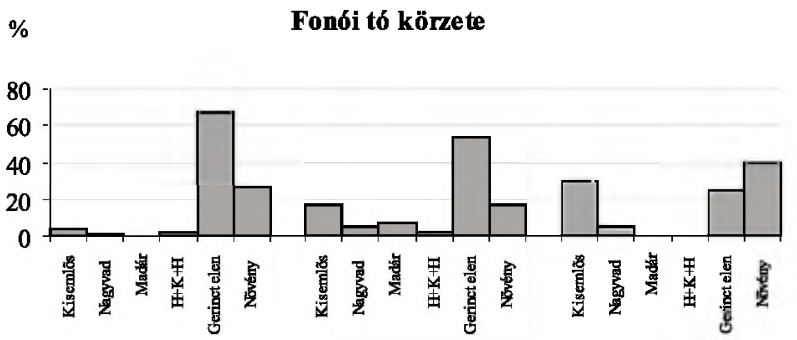

53. ábra: A borz táplálék-összetétele erdei és mezőgazdasági élőhelyen

Megjegyzés: $\mathrm{H}+\mathrm{K}+\mathrm{H}=$ hüllö, kétéltú és hal együtt, tömör oszlop jelzi a relatív gyakoriságés üres oszlop a biomassza számítás alapján kapott értékeket 


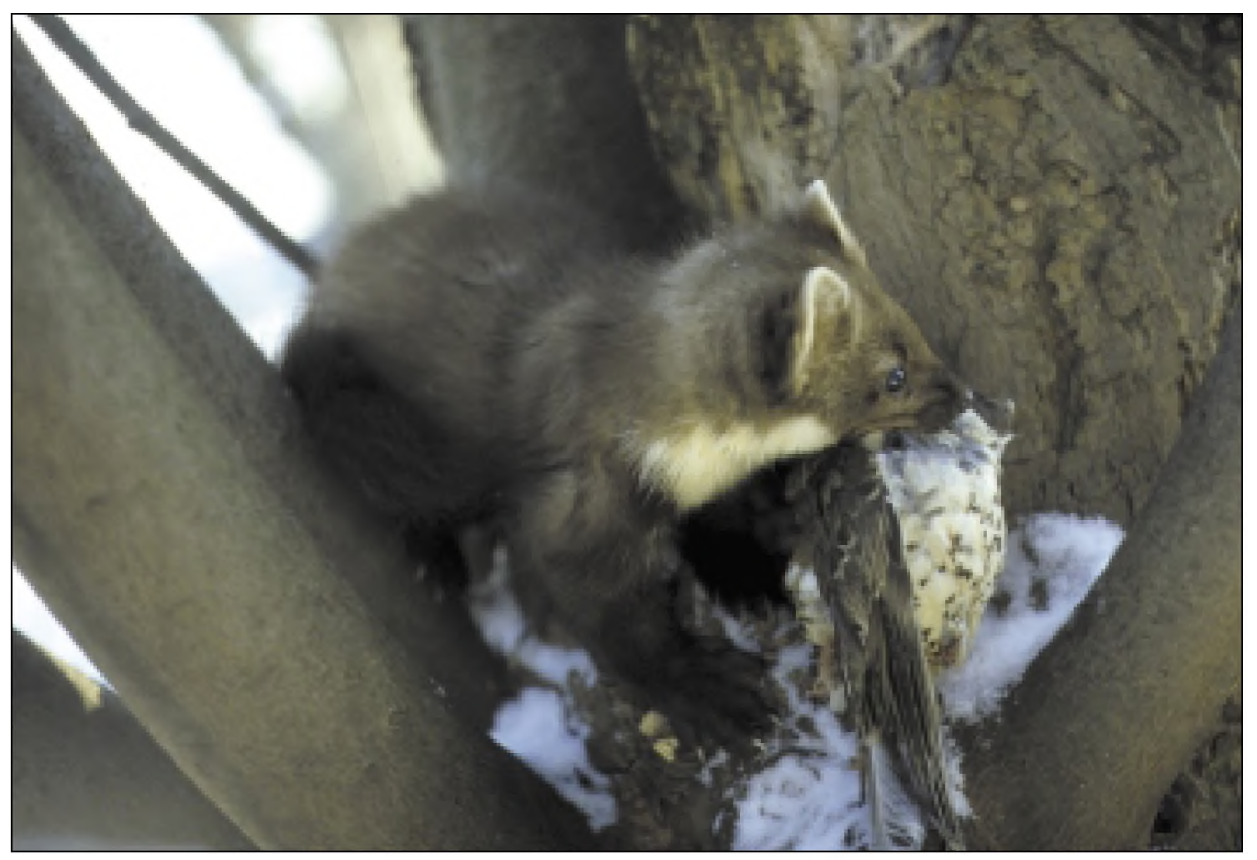

54. ábra: Nyuszt, madárzsákmányával

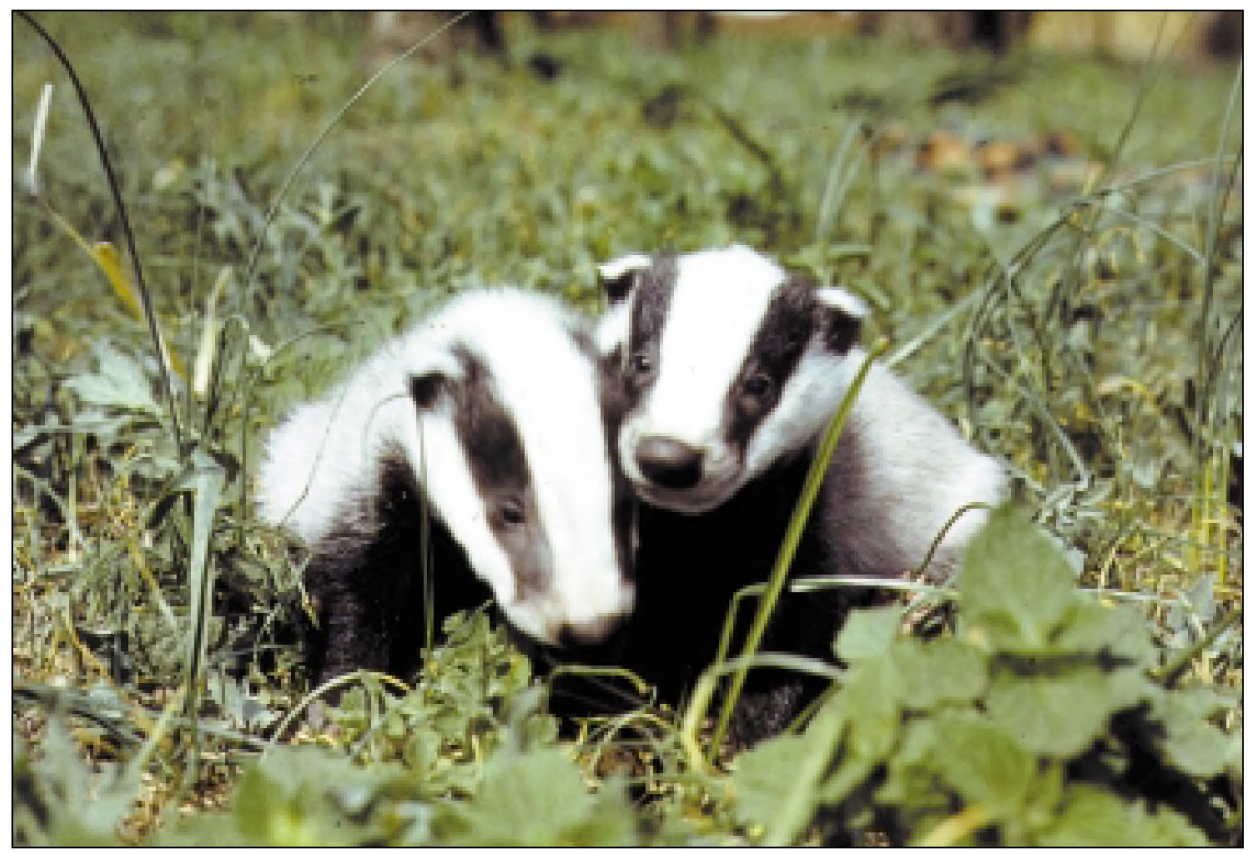

55. ábra: Borz (Meles meles) kölykök 


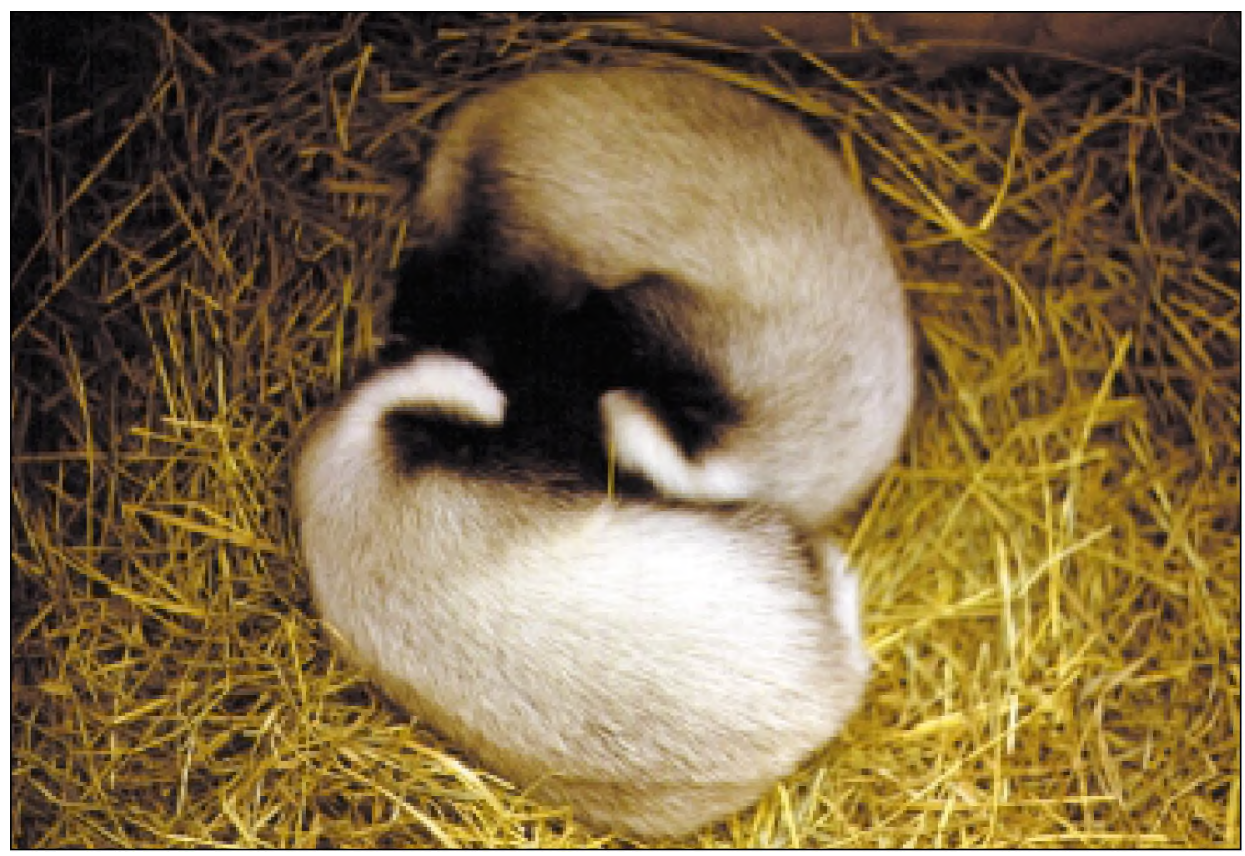

56. ábra: Alvó borzok

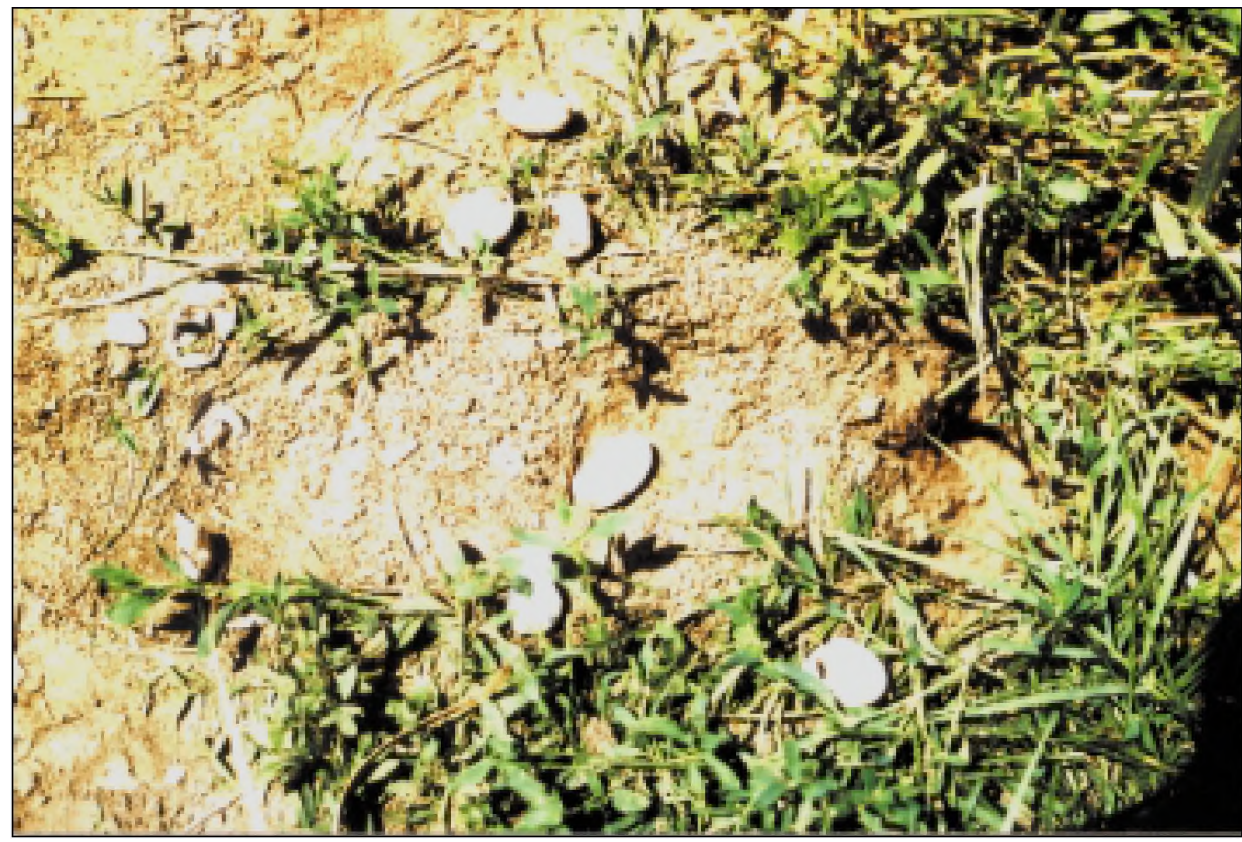

57. ábra: Borz által kifosztott teknösfészek 
A borz téli táplálkozásában a gerinctelenek elsődlegesen fontos szerepet töltöttek be, hiszen az elfogyasztott táplálék felét (49\%) tették ki. Tavasszal fontosságuk másodlagossá vált (19\%), majd nyáron és ôsszel szerepük tovább csökkent (4-6\%) (53. ábra és 13. melléklet). A gerinctelenekből álló táplálékban, biomassza számítás alapján, minden évszakban a gyürüsférgek (földigiliszta fajok) töltötték be a legjelentósebb szerepet. Leggyakrabban ganéjtúró bogarak fordultak elő táplálékként (tulajdonképp gyakrabban, mint a földigiliszta), de fogyasztott biomasszájuk lényegesen kisebb volt a gilisztáknál. Ezek mellett a különböző futó- és más bogár fajok, valamint lárvák, továbbá darazsak, ikerszelvényesek és csigák tették igen változatossá a borz táplálékát.

A növényi táplálék mennyisége télen és tavasszal alárendelt volt (2-6\%), majd nyáron lényegesen megnőtt a jelentósége $(17 \%)$ és ósszel már másodlagosan fontossá vált (26\%) (53. ábra és 13. melléklet). A téli és a tavaszi táplálékban jelentős arányban szereplő kukorica feltételezhetően a vadetetőkröl származott, tekintve, hogy szántóföldek több kilométeres távolságra találhatók. A nyári növények közül az erdei szamóca és a vadkörte, az őszi táplálékban a kökény, a vadkörte és a szeder fogyasztott biomasszája volt a legtöbb.

A Fonói tó körzetében, mezôgazdasági környezetben éló borz táplálékában a kisemlösök lényegesen gyakrabban szerepeltek, mint a vizsgált erdei élöhelyen (53. ábra és 13. melléklet). Nyáron és ősszel másodlagosan fontos szerepet töltöttek be (17-30\%). A kisemlősök között a legfontosabb a mezei pocok volt, de emellett erdei fajok is elöfordultak. Elhullott állatok (vaddisznó és szarvasfélék), valamint menyétfélék nagyobb gyakorisággal fordultak elő, mint az erdei élőhelyen, de szerepük ennek ellenére sem volt meghatározó.

A hüllök és kétéltüek szerepe elenyészően alacsony volt, halakat pedig nem fogyasztott (53. ábra és 13. melléklet).

A Fonói tó körzetében élö borz táplálékában tavasszal (67\%) és nyáron (53\%) a gerinctelenek játszották a legfontosabb szerepet, de még ősszel is a táplálék negyedét alkották (53. ábra és 13. melléklet). Leggyakrabban földigiliszták fordultak elő (évszaktól függóen 13-24\%), de ezek mellett a futóbogarak és galacsinhajtó bogarak szerepe is jelentős volt.

A növények tavasszal még másodlagosan fontos táplálékot jelentettek, őszre pedig elsődleges fontosságúvá váltak (53. ábra és 13. melléklet). A növényi táplálékban leggyakrabban kukorica és cseresznye szerepelt. A kukorica a tavaszi időszakban vadetetőről és vetésekről is származhatott, a nyári és őszi időszakban pedig már feltételezhetően a kukoricatermést dézsmálták meg. A kertekbe bejáró borz, ha teheti, a csemegekukoricát részesíti előnyben és közben a hullott gyümölcsből is fogyaszt.

Az erdei és a mezőgazdasági területen élö borz tápláléka a fő táplálék taxonok alapján szignifikánsan eltért a téli-tavaszi időszakban $(P<0,05)$, de nem különbözött a nyári-őszi félévben $(\mathrm{P}=0,833)$.

\section{A borz préda fajainak súlya és jellemző élōhelye}

Az erdei és a mezőgazdasági területen élő borzok táplálékában egyaránt a $15 \mathrm{~g}$ alatti súlytartományba sorolt préda fajok szerepeltek a leggyakrabban (69, illetve 76\%) (58. ábra). Ebbe a csoportba elsósorban gerinctelenek tartoztak (2. melléklet). A $15 \mathrm{~g}$ és $50 \mathrm{~g}$ közötti kategóriába a préda fajok negyede, illetve ötöde tartozott. A többi csoport szerepe nem volt jelentős.

A zsákmány fajok döntő többségét talajszinten élők alkották (58. ábra). Ezek aránya a Boronka-melléki Tájvédelmi Körzetben $83 \%$-ot, a Fonói tó körzetében 98\%-ot tett ki. A halastavakat körülvevő erdei élöhelyen élő borz táplálékában számottevő arányban (13\%) szerepeltek vízhez kötődő fajok, míg a bokrokon élő fajok fogyasztása jelentéktelen volt $(4$, illetve $2 \%)$. 


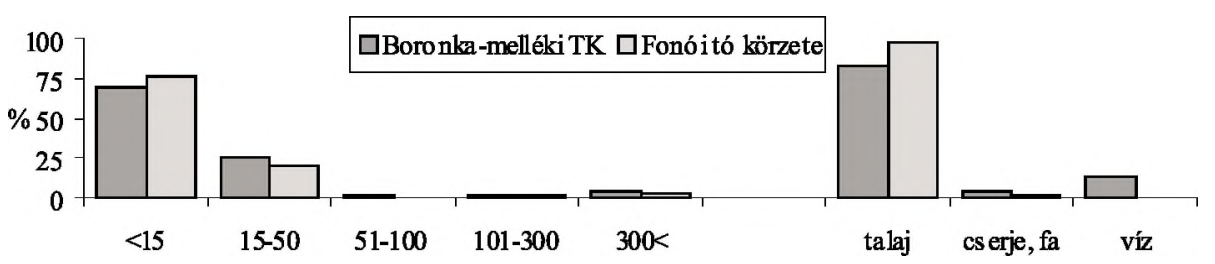

58. ábra: A borz prédaválasztása a zsákmány súlya és jellemző élőhelye szerint

\section{A borz táplálkozási niche-szélessége}

A borz táplálkozási niche-szélessége (59. ábra) a Boronka-melléki Tájvédelmi Körzetben, nyári-ôszi időszakban közepesnek mondható $(3,77)$, de téli-tavaszi időszakban alacsony $(1,93)$, valamint a Fonói tó körzetében egész évben közepesen alacsony volt (2,36-2,67). Ez annak köszönhetö, hogy tápláléka fajokban igen gazdag ugyan, de a 15 fó táplálék taxont figyelembe véve szélsőségesen magas és alacsony értékek egyaránt előfordultak.

Összességében megállapítható, hogy a borz tápláléka az élőhelytôl függően lényegesen különbözik. Az erdőkkel övezett halastavak körzetében élő egyedek táplálékában télen a gerinctelenek, ezen belül a földigiliszták a legjelentősebbek. Tavasztól-őszig pedig a hüllők és a kétéltủek jelentik a legfontosabb táplálékforrást. A kisemlősök és a többi zsákmány taxon szerepe nem jelentős. Ezzel szemben mezőgazdasági területen a borz tavaszi és nyári táplálékában a gerinctelenek (fóként a gyuúrüsférgek), ősszel pedig a növények dominálnak. A növényi táplálékban a kukorica szerepel leggyakrabban. Összel a kisemlősök közül különösen a mezei pocok fogyasztása jelentôs. A többi táplálék taxon szerepe alárendelt. Területtől függetlenül a borz tápláléka fajokban gazdag, de a nicheszélesség általában közepes, vagy alacsony, ami azt jelzi, hogy adott élöhelyen a táplálék-források szúk sávját használja ki. Táplálékában - a gerinctelenek gyakori előfordulása miatt - a kis súlyú, $15 \mathrm{~g}$ alatti, talajszinten élő préda dominált. A területenként lényegesen eltéró forráskihasználásra való képessége alapján, a borz táplálkozási szempontból jó alkalmazkodóképességü fajnak mondható.

A borz kutatásával kapcsolatos további részletek az alábbi sorszámú publikációkban találhatók meg: $[12,13,14,15,17,20,23,30]$.

Fonói tó körzete

Boronka-melléki TK

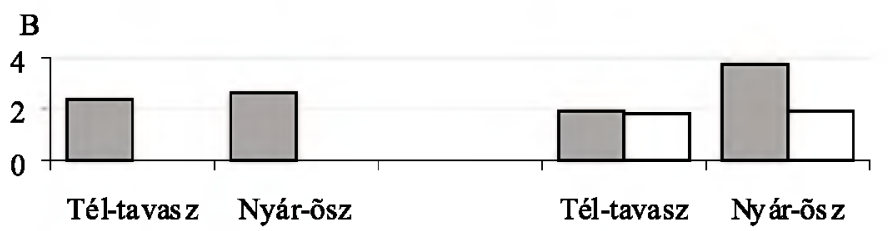

59. ábra: A borz táplálkozási niche-szélessége erdei és mezőgazdasági élőhelyen Megjegyzés: tömör oszlop jelzi a relatív gyakoriság- és üres oszlop a biomassza számítás alapján kapott értékeket 


\section{A vörösróka}

A vörösróka szinte az egész északi féltekén elterjedt faj. A lehető legváltozatosabb élőhelyeken, a szubtrópusi területektől a sarkkörig, a különféle típusú erdőktől a nagyvárosokig, a síkvidéki területektől a $3000 \mathrm{~m}$ magas hegyekig elöfordul (TRENSE 1989, MitCHELL-JoNES et al. 1999). Rendkívül jó alkalmazkodó-képességének köszönhetően betöltötte az üldözött nagyragadozók helyét, melyek visszaszorultak a kevésbé háborgatott hegyvidéki területekre. Folyamatosan növekvő terítéke mellett állománya növekszik, a hazai statisztika szerint 2000-ben 55 ezer példányból állt (CsÁNYI 1999, 2000, 2001). Magányosan, fơként szürkületben és éjszaka vadászik. Tápláléka rendkívül változatos, a gilisztáktól, rovaroktól, gyümölcsöktől egészen a közepes testú emlősökig terjed, de a nagyvadak és a háziállatok tetemeit is elfogyasztja. Opportunista ragadozó, vagyis a legnagyobb súrúségben elöforduló, legkisebb energia befektetéssel hasznosítható táplálékforrást részesíti előnyben.

A róka táplálék-összetétele viszonylag jól ismert, a nagyszámú tanulmányokból az Európában végzett vizsgálatok közül emelek ki néhány fontosabbat. A téma irodalmát HELTAY (1989) tekintette át részletesen.

Skandináviában, sarkvidéki feltételek mellett LINDSTRÖM $(1988,1989)$ vizsgálatai szerint a vörösróka fố táplálékát pocok fajok alkották. Azt a következtetést vonta le, hogy a róka ovulációs rátája szorosabb korrelációban áll a kölykök születésekor (tavasszal) tapasztalható rágesáló táplálék-készlettel, mint ami télen rendelkezésre állt. Svédország különböző klimatikus adottságú vidékein végzett másik vizsgálatban szintén a kisemlősök képezték a róka fö táplálékát, közülük is a pocokfélék fordultak elő leggyakrabban (ENGLUND 1965). A pocok gradáció évében a pocokfélék fogyasztása nagyobb volt, mint a többi évben. A pockot a róka előnyben részesítette az egerekkel szemben. Egyes svédországi nagy üreginyúl sürüségü területeken viszont a nyúl képezte a legfontosabb táplálékát. A rókagyomrokban házi macska, menyét, borz, sôt kétséget kizáróan elhullott róka maradványát is megtalálták. Alternatív zsákmányfogyasztás hipotézist tesztelve (ANGELSTAM et al. 1984, LINDSTRÖM et al. 1986) azt tapasztalták, hogy a rókák táplálékában nőtt az alternatív táplálék (nyírfajd és havasi nyúl) aránya az egyébként domináns tápláléknak számító kisemlősök állományának csökkenésekor. A szarvasfélék közül leggyakrabban ôz szerepelt táplálékként, mely a vadászható madarak egy részéhez hasonlóan, ENGLund (1965) feltételezése szerint vadászat után elhullott példányokból származhatott. A madarak közül legnagyobb arányban a vadászható fajdféléket és fácánt, kisebb részben tókés récét, szárcsát és erdei szalonkát evett a róka. Az egyéb táplálékféleségek között elófordultak gyíkok, keresztes vipera, békák, futrinkák, galacsinhajtók, pattanóbogarak, giliszta, kullancs, stb. Ezeken kívül a róka táplálékában szerepelt háziállatok vágásából származó hulladék és szemét is, továbbá kertekben és vadon termő gyümölcsök. A szerző közvetlen kukoricafogyasztást is feljegyzett. Dániában, erdővel tarkított mezógazdasági területekről származó minták alapján, szintén a kisemlősök bizonyultak a róka leggyakoribb tápláléknak (JENSEN és SEQUIRA 1978). A gyomrok 67\%ában találtak kisrágesálókat és a táplálékmaradványok 19-36\%-a származott élőhelytől függóen mezei-, vagy üregi nyúltól. Róka, borz, őz és háziállat (fóként baromfi) maradványok is elófordultak a táplálékban. Vadon éló madarak 37\%-ban szerepeltek, ezek egy 
része a tyúkalakúak és varjúfélék közé, vagy egyéb nagytestű madarak kategóriájába tartozott ( $\mathrm{pl}$. fácán és fogoly), de többségét a kistestú énekesmadarak közé sorolták.

Anglia különbözó mezőgazdasági területein a róka tavaszi táplálékában jelentôs volt a bárányok fogyasztása (35-40\%), bár az év más részében a kisemlősök domináltak (KoLB és Hewson 1979, 1980). Egy másik területen ősszel a nyúl-, tavasszal a madár fogyasztás volt nagyarányú. A juhok dögfogyasztásból származtak, ugyanis a táplálékban dögbogarakat és légylárvákat is találtak. LLOYD (1980) vizsgálata szerint ahol a két nyúlfaj egyaránt előfordul, vadászata során a róka előnyben részesíti az üreginyulat a mezeinyúllal szemben. A róka nagyfokú ökológia plaszticitását bizonyítja, hogy lakott területeken is képes megélni. Oxford város területén hullaték elemzés során megállapították (DONCASTER et al. 1990), hogy a kisrágcsálók aránya tél végén, a házak között élö nyulaké áprilisban, a madaraké júniusban, a növényeké ősszel volt a legnagyobb; továbbá elöfordult a róka táplálékaként földigiliszta és háztartási hulladék is.

Lengyelországi vizsgálat szerint (RYSZKOWSKI et al. 1971) évszaktól függően a róka legjelentősebb táplálékát kisrágcsálók, mezeinyúl és elhullott őz alkották. PIELowSKI (1976) vizsgálata szerint agrárterületen a róka predációjának tulajdonítható a felnôttt mezeinyúl állomány $2 \%$-os, a szaporulat $10 \%$-os csökkenése. Feltételezése szerint a rókák táplálékában talált nyulak jelentôs részét már elhullottan találta a róka. Szintén Lengyelországban végzett hullaték vizsgálatban (GosZCZYNSKI 1986) a róka táplálékában hasonló arányban találtak kisrágcsálókat ( $33 \%$, ebből mezei pocok $21 \%)$, madarakat (25\%, ebböl fácán $7 \%$ ) és nyulat (26\%). A kisemlösök nyáron és összel, a nyulak és a madarak télen és tavasszal fordultak elő nagyobb mennyiségben. A kisemlősök, valamint a nyúl és madár táplálék között negatív kapcsolat áll fenn. Pocok gradáció évében viszont a róka egész évben gyakrabban fogyasztott pockot. Az egyéb táplálékalkotók között szerepelt ôz, vaddisznó, kutya és róka is. A mezeinyúl fogyasztást befolyásolja a hőmérséklet és a hóval fedettség (GosZCZYNSKI 1977, 1986). Mély hóban gyakrabban ejtett zsákmányul mezeinyulat. Moravia déli részén, mezőgazdasági területen végzett hullaték analízisben leggyakoribb (a minták 62\%-ában) táplálékot a kisrágcsálók, közülük is a mezei pocok jelentette (KozENA 1988). Ezek mellett a mezeinyúl (46\%) is fontos szerepet töltött be. A fácán 20\%-os gyakorisággal szerepelt, továbbá kistestủ énekesmadarak, rovarok, valamint a minták $41 \%$-ában növények is előfordultak. Kelet-Ausztria hat különbözö területéról származó róka minták elemzés alapján (SUCHENTRUNK 1984) a róka táplálékspektruma igen szélesnek bizonyult, 80 különböző táplálékalkotót találtak. A vizsgálat szerint az ivarok közötti táplálék-összetételben megmutatkozó eltérés nem volt számottevő. A táplálékban azokban az idôszakokban szerepelt gyakran őz és zerge, amikor magas volt ezek mortalitása. Az elhullott állatok teteme fontos táplálékforrást jelent a róka számára, másrészt a róka a dögeltakarítással jelentós "szanitéc" szerepet is betölt.

Olaszország mediterrán éghajlatú vidékén a róka táplálékának nagy részét rovarok alkották még a téli hónapokban is (CIAMPALINI és LoVARI 1985). Az év nagy részében rendelkezésre álló gyümölcsökböl is jelentős mennyiséget fogyasztott. Kisemlös és madárfogyasztás a vemhesség és a szoptatás időszakában volt jelentős. Görögországban összesen 70 különböző táplálék fajt határoztak meg (PAPAGEORGIOU et al. 1988), melyek közül a legnagyobb arányban a kisrágcsálók, majd a háziállatok és a gyümölcsök szerepeltek. Az apróvad fajok nem játszottak jelentős szerepet a róka táplálkozásában. Portugáliában végzett vizsgálatok szerint (SARMENTO és CRUZ 1998) a mezeinyúl predáció 43\%ban a vörösrókának, továbbá 24\%-ban a nyestnek, 12\%-ban a vadmacskának (Felis silvestris), 9\%-ban az ibériai hiúznak (Lynx $l$. pardinus) és 12\%-ban a petymegnek (Genetta genetta) tulajdonítható.

Az elsố jelentős hazai vizsgálatot ERDEI (1977) végezte a Tisza-Maros szögében, ártéri erdei, mezőgazdasági és emberi zavaró hatásoknak kitett területen. A gyomortartalom vizsgálat szerint a vörösróka domináns táplálékát kisemlősök $(46 \%)$, fóként mezei po- 


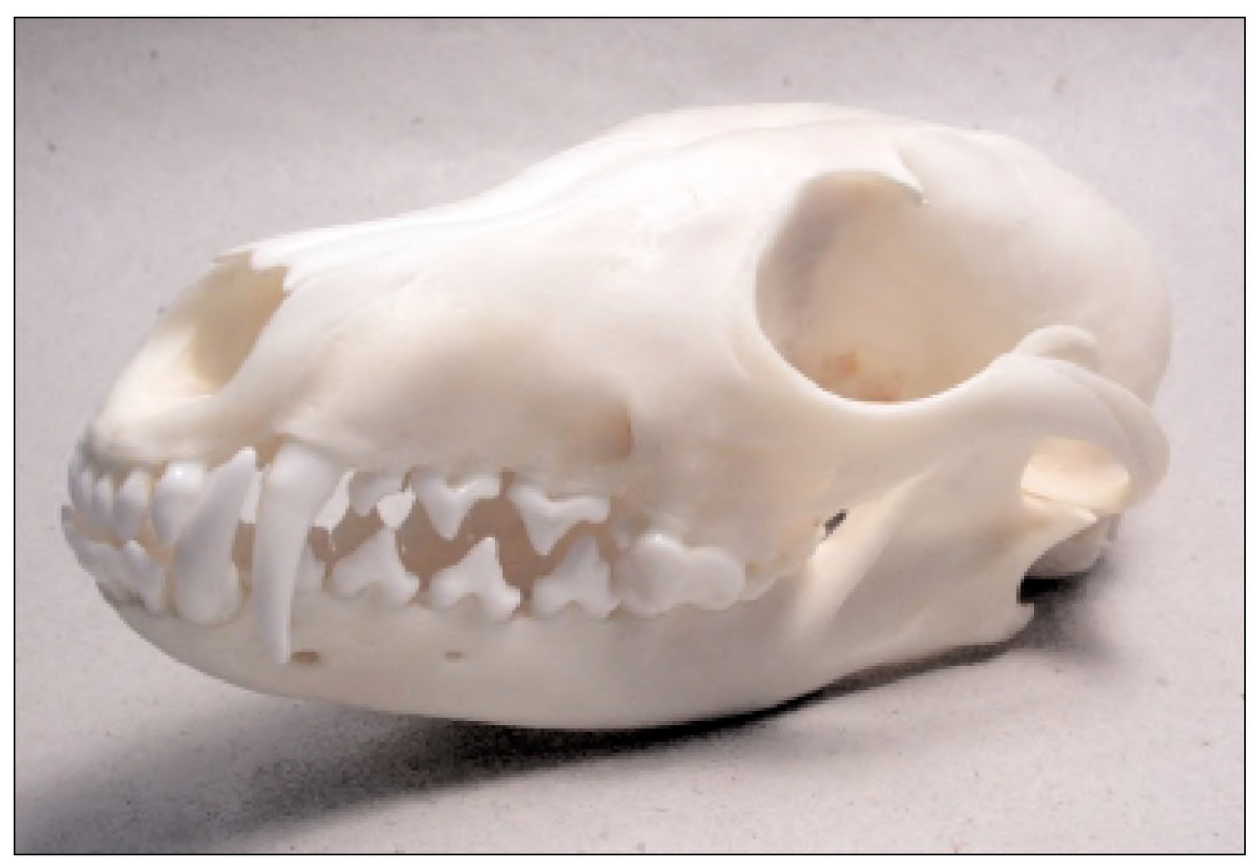

60. ábra: Vörösróka (Vulpes vulpes) fotó: Nagy Lóránt

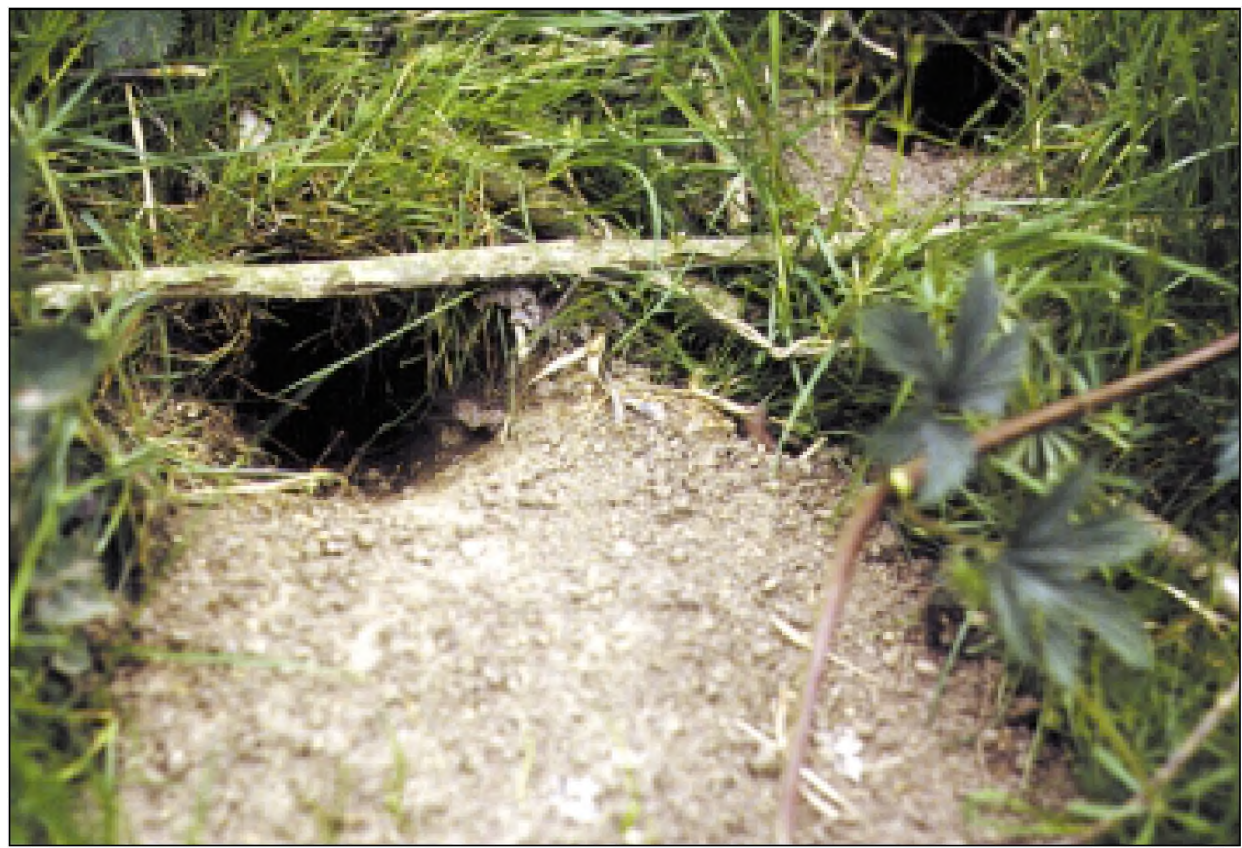

61. ábra: Róka kotorék kijárata 


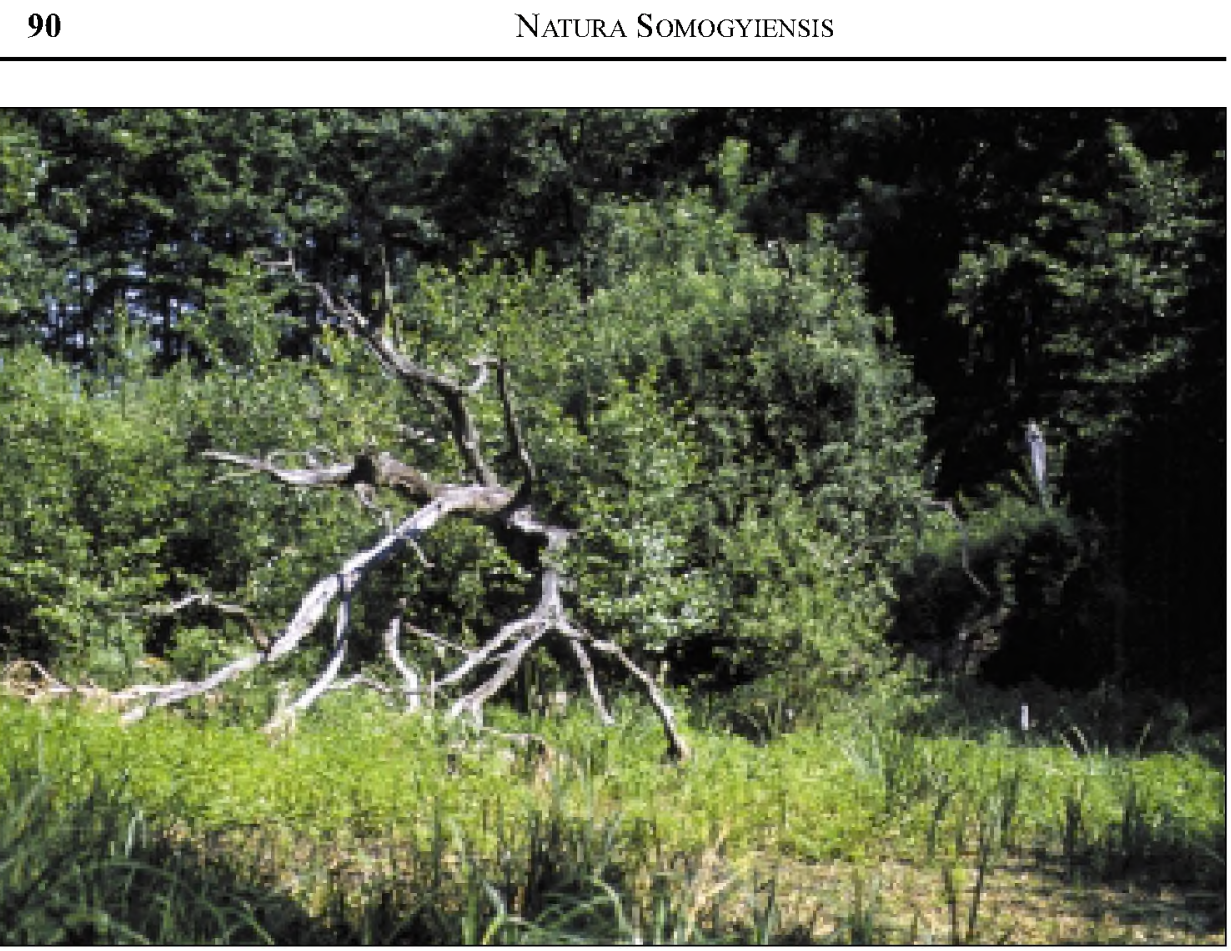

62. ábra: Rókák és nyusztok kilátó fája a Lankóci erdỏben

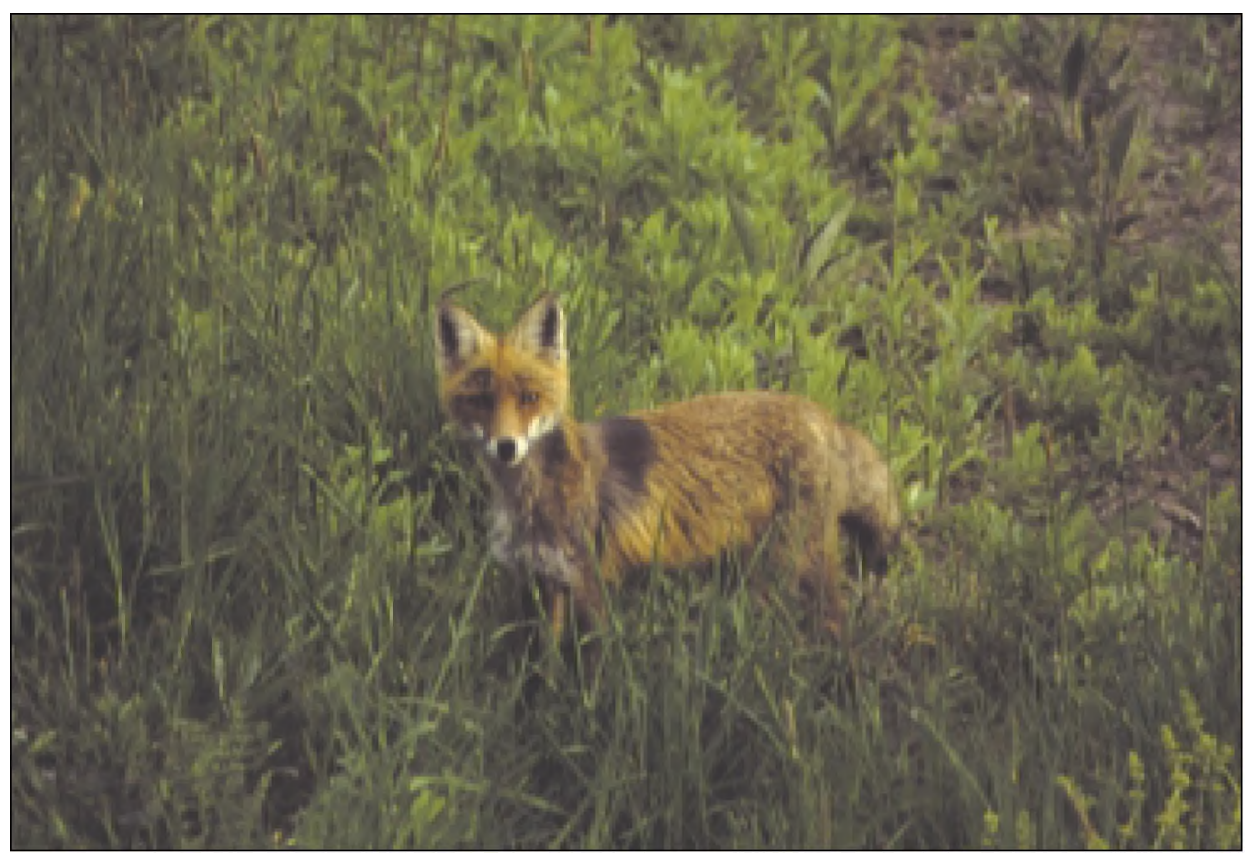

63. ábra: Figyelö róka 
cok, valamint rovarok (24\%) alkották. A táplálékban a mezei nyúl területtől függően $3,5 \%$ és $5,5 \%$, a szárnyas vad $8 \%$ alatti arányban szerepelt. A vadászható madarak fóként az őszi-téli vadászati szezonban fordultak elö jelentősebb mennyiségben. Lényeges eltérést tapasztalt a különböző élőhelyek rókáinak táplálék-összetételében. Így a Szeged közelében élő rókák gyakran fogyasztottak hulladékokat és elhullott állatokból. A gyomrokban található táplálékmaradványok súlya alapján végzett elemzés szerint (FARKAS $1983)$ a róka legfontosabb táplálékai között tavasszal kisrágcsálók (44\%) és háziállat vágási hulladékok (21\%), valamint mezeinyúl $(19 \%)$ és fácán $(12 \%)$ szerepelt. A mezeinyúl táplálék zömmel néhány napos és hetes korú egyedekből állt. Nyáron a táplálékot kisrágcsálók $(50 \%)$, fácán $(23 \%)$ és növények (16\%), ősszel szintén kisrágcsálók (32\%), vágási hulladék (21\%) és növények (31\%), télen pedig kisrágcsálók $(42 \%)$, vágási hulladék (31\%) és fácán $(12 \%)$ alkották. Az Országos Ragadozó Monitoring Program (SZEMETHEY et al. 1998, 2000) keretében 1997-tól végzett gyomortartalom vizsgálatok többségében alföldi, mezőgazdasági művelés alatt álló területeken (Abádszalók, Borsodivánka), vagy nemzeti parkban nyílt füves pusztán, mocsaras élóhellyel mozaikos élöhelyen (Dévaványa, Egyek,), illetve dombvidéki, mezógazdasági területen (Fonyód-Zics) zajlottak (BEGALA et al. 2000, HeLTAI et al. 2000a). A vizsgálat eredménye szerint a róka domináns táplálékát mindegyik élőhelyen a kisrágcsálók alkották. Arányuk éves átlagban $50 \%$ körül alakult. További gyakori táplálékot a gerinctelenek és a növények jelentettek, de előfordult döghús, valamint alacsony arányban vadászható fajok, így a mezei/üregi nyúl ( $0-11 \%)$ és a fácán (2-7\%) fogyasztása is. A vizsgálat rámutatott arra, hogy a fácán- és nyúl állományok sürüsége (a becsült törzsállomány, illetve a fácánkibocsátás), valamint a róka apróvad fogyasztása között nincs statisztikailag alátámasztható összefüggés. A magasabb apróvad sürüségű területeken nem volt magasabb az említett apróvadfajok fogyasztása, vagyis a róka predációja nem befolyásolja ezen vadfajok állományának alakulását. Feltételezhető, hogy bizonyos sürűség felett az apróvad "kiszabadul" a ragadozó hatása alól, állományváltozását nem a ragadozó, hanem más, pl. élőhelyi tényezők alakítják (BEGALA et al. 2000, HeLTAI et al. 2000a).

A kutatási eredményekből látható, hogy a róka apróvadban okozott súlyos kártételére vonatkozó feltételezéseket a külföldi és hazai vizsgálatok többsége is cáfolja. A folyamatosan növekvő rókalétszám mellett azonban nem nehéz belátni, hogy azon a területen, ahol több róka él, a kisebb arányú apróvad fogyasztás is jelentős mennyiségben összegződik. A létszámnövekedés (HELTAI et al. 2000c) azonban további súlyos problémákat is felvet, melyek már a táplálkozási kapcsolatokon túlmutatnak.

Nem elhanyagolható szempont, hogy a vörösróka hazai táplálkozási szokásainak ismerete praktikus összehasonlítási alapot jelent a ma még kevéssé ismert kompetítor fajok (farkas, hiúz, aranysakál) kutatása során.

A továbbiakban a mezőgazdasági és erdei élőhelyeken végzett vizsgálatok eredményeit ismertetem.

\section{A vörösróka táplálék-összetétele mezógazdasági területeken}

\section{A Fonói tó körzete}

A Fonói tó körzetében élő róka táplálékában minden évszakban a kisemlősök domináltak, relatív gyakoriságuk 30\% és $48 \%$ között változott. Legkevesebb kisemlős fogyasztás nyáron, legtöbb ósszel és télen fordult elő (64. ábra, 14. melléklet). A zsákmány fajok között legjelentősebb a mezei pocok volt, de az erdei pocok és az erdei egér fajok is fontos szerepet töltöttek be táplálkozásban. Nyáron elöfordult pelefélék, és ósszel mókus fogyasztása is. A mezeinyúl előfordulási gyakorisága évszakonként egy százalék alatt maradt. 
A téli, relatíve táplálékszegény időszakban jelentős volt a dögfogyasztás (19\%), mely a nyári, őszi hónapokra lényegesen mérséklődött (64. ábra, 14. melléklet). Az elhullott állatok között többségében vaddisznó és szarvasfélék szerepeltek, de elófordult táplálékként borz is.

A falu közelségéből adódóan a róka táplálékában gyakran szerepeltek különböző háziállatok (64. ábra, 14. melléklet). Arányuk nyár (4,4\%) kivételével 10\% fölött mozgott. A legfontosabb táplálékot a baromfifélék jelentették, de vágási maradékból (pl. kecske), és valószínűleg elpusztulva talált egyedekből (pl. kutya, házimacska, házinyúl) is fogyasztott.

A madarak előfordulási gyakorisága a táplálékban nagyjából állandónak tekinthető, 8$10 \%$ között mozgott (64. ábra, 14. melléklet). A táplálék fajok többségét kistestú énekesmadarak alkották. A fácán részaránya a vadászati idényben volt számottevố (télen és ősszel 3-3\%), míg tavasszal és nyáron 1\% körül alakult.

A hüllök, kétéltülek és halak nem játszottak fontos szerepet a róka táplálkozásában.

A gerinctelenek tavasszal és nyáron egyaránt magas arányban (24-24\%) fordultak eló, míg télen és ősszel szerepük jelentéktelen volt (24. ábra, 14. függelék). Tavasszal a cserebogarak fogyasztása $(7 \%)$ érdemel említést, egyébként a futóbogarak gyakoribb táplálékot jelentettek.

A növényi táplálék aránya télen és tavasszal hasonló szinten mozgott (12-13\%), majd nyáron és összel megkétszerezôdött (64. ábra, 14. melléklet). A legfontosabb növényi táplálék télen és tavasszal a szórókon fogyasztott kukorica, nyáron a cseresznye, ősszel a kökény és a szölố volt. A fogyasztott gyümölcsök jelentôs része kertekben termett.

Az emberi település közelében élő róka táplálékában emészthetetlen hulladékok, pl. nylon, alumínium fólia, papír is előfordult (64. ábra, 14. melléklet). Ez azt jelzi, hogy a róka hulladékok között, szemétdombokon is táplálkozott. Kertek körüli táplálék keresését, különösen a tavasz végi és nyári kölyöknevelési idôszakban, számos alkalommal, közvetlen megfigyeléssel is bizonyítani lehetett.

\section{A vörösróka táplálék-összetétele az aranysakál hazai elterjedésének központjában}

\section{Kétújfalu körzete}

Kétújfalu körzetében, az aranysakál hazai elterjedésének központjában a vörösróka elsődlegesen fontos táplálékát minden évszakban kisemlósök alkották (24. ábra, 14. függelék). A kisemlósök biomassza számítás szerinti aránya 80\% és 94\% között mozgott, legfontosabb táplálék faj a mezei pocok volt (47-85\%). Emellett az erdei pocok, valamint az erdei egerek és tavasszal a cickányfélék töltöttek be fontos szerepet. Ilyen nagyarányú kisemlös fogyasztás egyetlen más, vizsgált róka élőhelyen sem fordult elö. Tápláléka alapján nyári-őszi időszakban kifejezett mezei pocok specializáció volt megfigyelhetố.

Mezei nyúl csak nyáron és ósszel szerepelt a róka táplálékában, biomassza számítás szerinti részesedése $0,4 \%$ alatt maradt (64. ábra, 14. melléklet). Ebben közrejátszott, hogy a területen a nyúlsürüség egyébként is igen alacsony.

A csülkös vadak fogyasztott biomasszája évszakonként $0,1 \%$ és 2,6\% között változott, nagyvad fogyasztása télen és tavasszal fordult elő leggyakrabban. A nagyvadak közül a vaddisznó és a gímszarvas szerepelt legtöbbször, a fogyasztás nagy valószínúséggel dögből történt (64. ábra, 14. melléklet). A Kétújfalu körzetében élö rókák lényegesen kevesebb nagyvadat fogyasztottak téli és tavaszi időszakban, mint bármely más vizsgált területen az ott élő rókák (14. függelék).

Háziállat ősszel fordult elő számottevő mennyiségben táplálékként, (64. ábra, 14. melléklet). A róka valószínúleg elpusztult kutyából fogyasztott, szarvasmarha és sertés húst pedig dögkútból evett. 


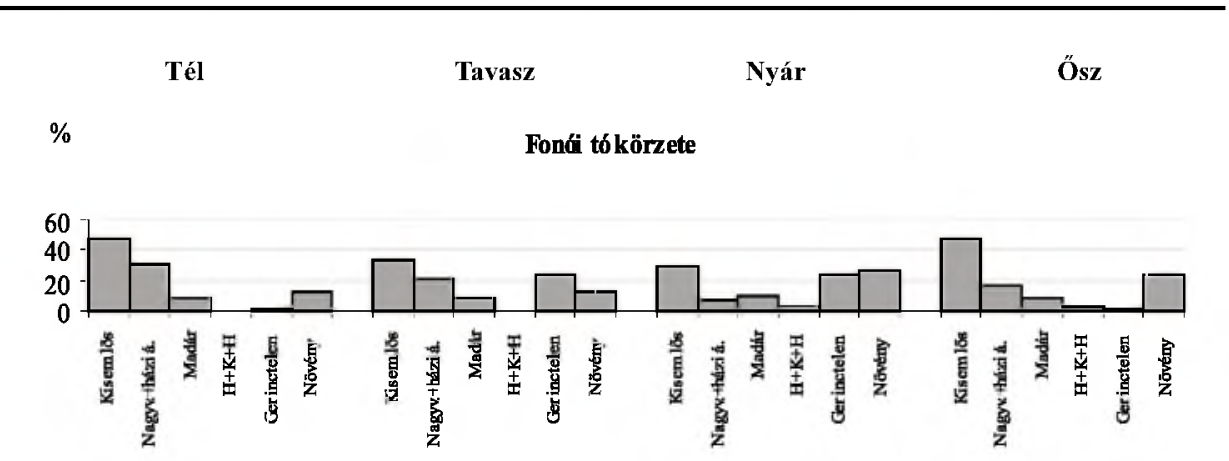

$\%$

Kétújfalu körzete

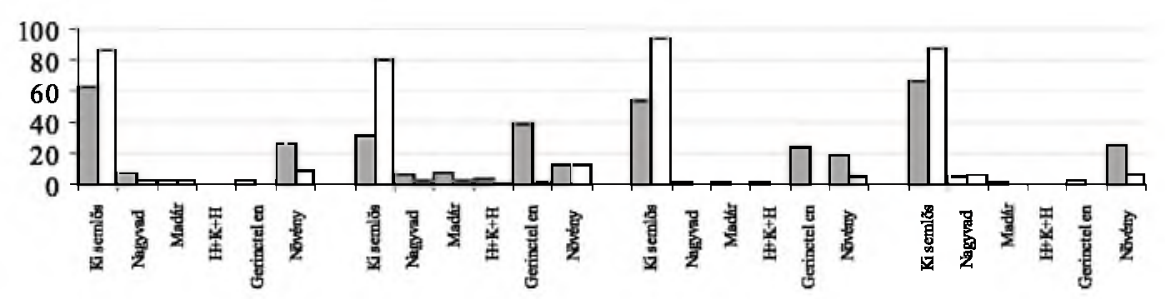

Mike-Csököly (tél-koratavasz)

Mike-Petesmalom (tél-koratavasz) ${ }^{*}$

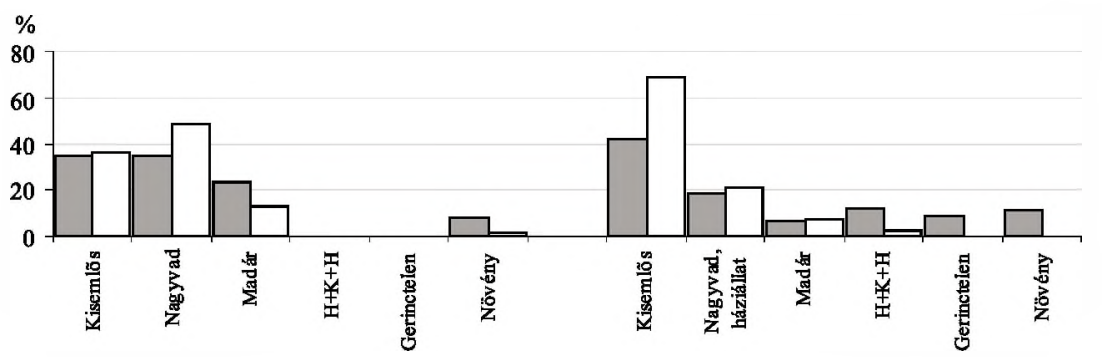

64. ábra: A vörösróka táplálék-összetétele mezógazdasági területeken Megjegyzés: $\mathrm{H}+\mathrm{K}+\mathrm{H}=$ hüllő, kétéltű és hal együtt, tömör oszlop jelzi a relatív gyakoriságés üres oszlop a biomassza számítás alapján kapott értékeket; * erdei élóhely

Madarak minden évszakban szerepeltek az étlapján, azonban a Mike körzetében élő rókához képest lényegesen kisebb arányban (64. ábra, 14. melléklet). Fácán csak télen a vadászati idényben fordult elő (biomasszája 2,2\%), az év többi részében a kistestủ madarak fogyasztása volt jelentősebb.

Hüllók tavasszal és nyáron kis mennyiségben szerepeltek a róka táplálékában.

A gerinctelenek nyáron és tavasszal gyakran fordultak eló (24-39\%), azonban fogyasztott biomasszájuk kicsi volt (1-3\%). Közülük leggyakrabban futóbogarak szerepeltek a róka étrendjében, de tavasszal jelentős volt a májusi cserebogár fogyasztás. Az eredmények azt mutatják, hogy a kifejlett és a fiatal rókák egyaránt előszeretettel vadásznak különbözô bogarakra.

A növényfogyasztás minden évszakban jellemző volt. Bár az év nagy részében, az esetek negyedében, ötödében növényt is evett a róka, a növények biomassza szerinti rész- 
aránya "csak" 6\% és 12 \% között mozgott. Összel és télen a vadon termő gyümölcsök közül a kökény, tavasszal a napraforgó, nyáron a szeder illetve a cseresznye fordult elö számottevő mennyiségben táplálékként. A füfélék fogyasztott biomasszája gyakori előfordulásuk ellenére kicsi volt.

A vörösróka tápláléka az aranysakál hazai elterjedésének peremén

\section{Mike-Csököly körzete}

A Mike és Csököly községek közötti területen 1996 és 1997 telén és tavaszán az aranysakál táplálékát, majd egy évvel késóbb a sakál eltünését követően, 1997/1998 telén és tavaszán a vörösróka táplálék-összetételét vizsgáltam. Ebben az időszakban ez a terület még az aranysakál hazai elterjedésének a peremén helyezkedett el (HELTAI et al. 2000b). A kérdés az volt, hogy a sakál és az ezt felváltó róka tápláléka eltér-e egymástól.

A vörösróka táplálékában a kisemlősök és az elhullott nagyvadak egyenlő előfordulási gyakorisággal szerepeltek (35-35\%) (64. ábra, 14. melléklet). A róka a kisemlősök közül a mezei pockot fogyasztotta legnagyobb mennyiségben. Az elfogyasztott táplálék biomassza számítása alapján viszont az (elhullott) nagyvadak elsődlegesen fontos táplálékot jelentettek (48\%), a kisemlősök csak másodlagos szerepet töltöttek be. Nagyvad dominanciát (!) egyetlen más, e könyvben bemutatott kis-, vagy közepes testméretú ragadozó emlösnél sem tapasztaltam. Ezen a téren tehát rendhagyó a Mike-Csököly térségében élt rókák téli-koratavaszi tápláléka (és ennek függvényében értékelendô az itt élt sakál tápláléka is). A csülkös vadak közül táplálékként a vaddisznó és a dámvad fordult elő legnagyobb mennyiségben. A táplálékmaradványok alapján ezek mind kifejlett egyedek voltak, melyeket a rókák egyértelmüen nem képesek zsákmányul ejteni. Továbbá, ebben a korai idốszakban a szarvasfélék ellése még nem kezdődött el. Ha ezeket a nagyvadakat sakál ejtette volna el - ami az egészséges vaddisznó és gímszarvas esetében is kizárható- akkor azok nem engedték volna át a prédát más ragadozónak.

Jelentős volt a róka madárfogyasztása (64. ábra, 14. melléklet). Leggyakrabban a kistestú madarak $(15 \%)$, a fogyasztott biomassza adatok alapján pedig a vadászható fácán $(8,5 \%)$ volt a jelentősebb madártáplálék.

Egyéb préda nem fordult elő a róka táplálékában (64. ábra, 14. melléklet). Növények közül tôkén hagyott szólöt, valamint kukoricát fogyasztott (biomasszája 2\%).

A sakál hazai elterjedésének peremterületén (Mike-Csököly), valamint központjában (Kétủjfalu-Lakócsa) éló vörösróka téli-tavaszi tápláléka között lényeges eltérés volt tapasztalható $(\mathrm{P}<0,05)$.

\section{A vörösróka táplálék-összetétele erdei élỏhelyeken}

A Boronka-melléki Tájvédelmi Körzet és Petesmalom vizsgált területei hasonlóak abból a szempontból, hogy nagy kiterjedésú erdók zárnak közre halastavakat. A tájvédelmi körzetben erdőrezervátumot és széles védőzónát jelöltek ki, ahol természetszerú erdőgazdálkodás folyik. Petesmalomban, a tavak körüli erdőkben régi hagyományokra visszatekintő nagyvadgazdálkodás folyik. A Duna-Dráva Nemzeti Park részét képezố Lankóci-erdő abban tér el a fenti két területtől, hogy nagy kiterjedésủ tavak helyett csak morotvák, csatornák és sásos élőhelyek fordulnak elö. A vizes élőhelyek kiterjedését növeli, hogy az éger liget erdố az év jelentős részében vízben áll. A vizsgálati időszakban a védett erdőben intenzív erdőgazdálkodás zajlott, mely az értékes erdőállományokat is érintette. 


\section{Petesmalom körzete}

A Petesmalomban található halastórendszer mindössze néhány kilométerre fekszik az előzóekben ismertetett Mike-Csökölyi területtől (86. ábra a mellékletben). A vörösróka téli-koratavaszi táplálékában a kisemlősök domináltak, fogyasztott biomasszájuk $68 \%$ ot tett ki (64. ábra, 14. melléklet). A legfontosabb mezei pocok mellett rovarevők (vakond és cickányfélék), valamint nagy pele is elófordult táplálékként.

A róka nagyvad (dög) fogyasztása lényegesen alacsonyabb volt (biomasszája 14\%), mint a szomszédos területen (64. ábra, 14. melléklet). A táplálékként előforduló közönséges görény és macska akár predációból, a juh pedig a területen tartott állatok vágási maradékából származhatott.

A madárfogyasztás a Fonói tó körzetében élő rókához hasonlítható leginkább (64. ábra, 14. melléklet). A kistestü madarak és a fácán fogyasztott biomasszájának aránya egyenlố volt $(3,7-3,7 \%)$.

A nagy kiterjedésủ vizes élőhelyek adta lehetőségnek megfelelően hüllók, kétéltüek és halak viszonylag gyakran fordultak elö táplálékában (64. ábra, 14. melléklet), de fogyasztott biomasszájuk aránya 3\% alatt maradt.

Az ízeltlábúak közül a lótücsök, valamint a futóbogarak fogyasztása volt számottevő. A növények közül a füfélék és a kukorica szerepelt gyakran táplálékként, azonban kicsi volt $(0,4 \%)$ ezek biomassza szerinti részesedése.

\section{Boronka-melléki Tájvédelmi Körzet}

A Boronka-melléki Tájvédelmi Körzetben a vörösróka elsôdlegesen fontos táplálékát minden évszakban kisemlősök képezték (65. ábra, 15. melléklet). A kisemlősök fogyasztott biomasszájának aránya évszakonként $46 \%$ és $71 \%$ között változott, legtöbb tavaszszal és legkevesebb nyáron volt. A táplálék fajok között legfontosabb erdei pocok biomassza számítás szerinti részesedése $29 \%$ és $51 \%$ között alakult. A kisemlős táplálékban jelentős szerepet töltöttek be az erdei egerek is, valamint ritkán előfordult táplálékként vándorpatkány, törpeegér, pézsmapocok, vízipocok, mókus és nagy pele is. Cickány, valamint mezögazdasági kultúrához kötődő mezei pocok igen ritkán szerepelt táplálékában. A mezei nyúl a területen, jellemzően igen ritkán előforduló faj, ennek ellenére a róka táplálékában a téli időszak kivételével $0,5 \%$ alatti fogyasztott biomasszával szerepelt. Kistestủ menyétféle tavasszal és nyáron $0,1 \%$-os arányban, feltételezhetően zsákmányolásból eredően előfordult táplálékként.

A róka téli táplálékának biomassza számítás szerint az ötödét tették ki elhullott nagyvadak (65. ábra, 15. melléklet), melyek között legfontosabb a vaddisznó volt. Fogyasztásuk aránya őszig fokozatosan csökkent.

A tájvédelmi körzet központjában élő róka táplálékában a háziállat fogyasztás ritkaságnak számított. A vizsgálat négy éve alatt két-két alkalommal fordult elô kutya, illetve házimacska fogyasztása (15. melléklet). A kutya esetében feltételezhető a dögfogyasztás (lelött kóbor állatból), a macskánál viszont a predáció nem zárható ki.

A madártáplálék jelentősége tavasszal és nyáron nőtt meg (65. ábra, 15. melléklet), fogyasztott biomasszája elérte a 11\%-ot. A madártáplálékban a fácán részesedése annak ellenére számottevő volt (biomassza 1-6\%), hogy az alapvetően erdei környezetben és természetvédelmi kezelésben levő területen apróvad kibocsátás és vadászati hasznosítás nem folyt. A halastavakat övezó nádasok, bokorfüzes élöhelyek kedvezó feltételeket biztosítottak a különböző vízimadarak számára, melyek a róka táplálékában is szerepeltek. Így például az étlapján előfordult vízityúk, szárcsa, réce, vöcsök és nagykócsag is.

A hüllö́k, a kétéltúiek és a halak nem töltöttek be fontos szerepet a róka táplálkozásában (65. ábra, 15. melléklet), azonban többféle fajból is fogyasztott, így például mocsári teknős tojását, vízisiklót, gyíkokat, békákat és különböző halakat. 
A gerinctelenek bár tavasztól-őszig igen gyakran (23-32\%) és nagy fajgazdagsággal szerepeltek a táplálékban (65. ábra, 15. melléklet), fogyasztott biomasszájuk alacsony szinten mozgott $(0,4-2 \%)$. Leggyakrabban futóbogarakat evett.

A növények nyári és őszi időszakban a róka másodlagosan fontos táplálékát képezték (65. ábra, 15. melléklet). Az erdei gyümölcsök érésének idején a táplálék harmadát tették ki, a téli és tavaszi időszakban viszont fogyasztott biomasszájuk mindössze $4 \%$ körül alakult. A téli növényi táplálékban a vadetetőkroól származó kukorica, tavasszal a vadon termő cseresznye, nyáron a vadkörte és a szeder, ősszel pedig a vadkörte volt a legjelentósebb.

\section{Lankóci-erdő}

A Lankóci-erdőben élő vörösróka elsődlegesen fontos táplálékát minden évszakban kisemlósök alkották (65. ábra, 15. melléklet), melyek fogyasztott biomasszájának aránya évszaktól függően szủk határok (56-69\%) között mozgott. A két legfontosabbnak számító táplálék taxon, az erdei pocok és a Microtus fajok közel azonos szerepet töltöttek be a táplálkozásban. A mezei pocok magas arányú fogyasztása azt jelzi, hogy a Lankóci-erdőben élő róka gyakran kereste fel a mezógazdasági területeket is. Télen és ősszel az erdei egerek, tavasszal a vízipocok jelentősége nőtt meg. Mezei nyúl csak télen $(1,5 \%)$ és ősszel $(0,5 \%)$ fordult elô táplálékként.

A csülkös vadak fogyasztott biomasszája télen és tavasszal volt számottevő (12\%, illetve 16\%), majd jelentóségük öszig visszaesett (65. ábra, 15. melléklet). Legfontosabb nagyvad a vaddisznó volt. A csülkös vadak a kutyához hasonlóan valószínúleg dögfogyasztásból, a macska pedig predációból is származhatott.

Tél

$\%$

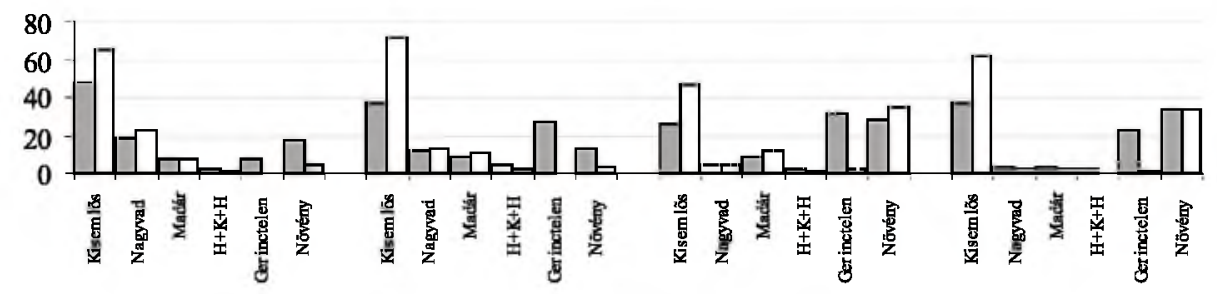

$\%$

Lankóci-erdõ

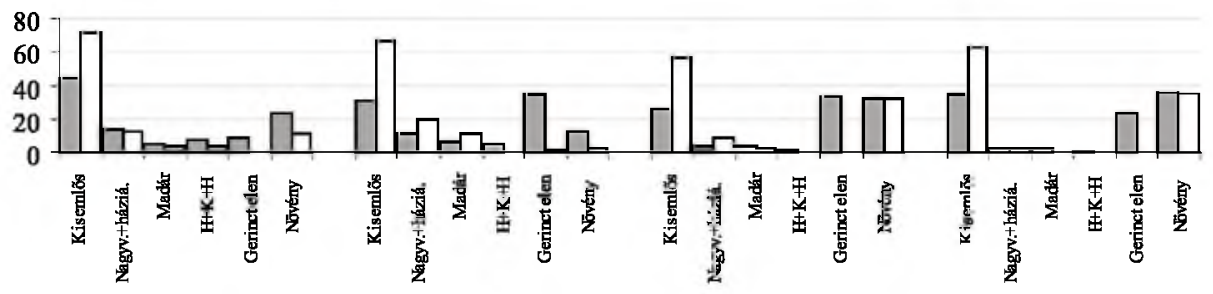

65. ábra: A vörösróka táplálék-összetétele erdei élóhelyeken

Megjegyzés: $\mathrm{H}+\mathrm{K}+\mathrm{H}$ = hüllők, kétéltűek és halak együtt; tömör oszlop jelzi a relatív gyakoriságés üres oszlop a biomassza számítás alapján kapott értékeket 
A madarak előfordulási gyakorisága a tavaszi időszak kivételével alacsony volt $(0,1$ 4\%). A madártáplálékban legnagyobb biomasszával télen és tavasszal a fácán (2,5-4\%) és tavasszal a vizes élóhelyekhez kötődó récék (6\%) szerepeltek (65. ábra, 15. melléklet).

A hüllők, kétéltủek és halak szerepe a róka táplálkozásában télen nagyobb arányú volt, mint a Boronka-melléki Tájvédelmi Körzetben (65. ábra, 15. melléklet), de az év többi részében fogyasztásuk alacsony szinten mozgott.

A gerinctelenek tavasztól-őszig gyakran és nagy fajgazdagsággal szerepeltek a róka étlapján, de fogyasztott biomasszájuk még az 1\%-ot sem érte el (65. ábra, 15. melléklet). Leggyakrabban ezen a területen is futóbogarakat evett.

Növények alkották a róka nyári és öszi táplálékának harmadát (65. ábra, 15. melléklet), és szerepük a téli időszakban is számottevő volt (11,5\%). A legfontosabb növényi táplálék télen a kökény, tavasszal a füfélék, nyáron a vadkörte és a szeder, ősszel pedig a vadkörte és a kökény volt.

\section{A vörösróka kisemlös preferenciája}

A Boronka-melléki Tájvédelmi Körzetben a kisemlős táplálék-készlet a nyusztnál leírtak szerint alakult (49 ábra).

A vörösróka legfontosabb zsákmányát, az erdei pockot a kisemlős táplálék-forrásban való előfordulásánál nagyobb gyakorisággal fogyasztotta (66. ábra). A vizsgálat három évére vonatkozó átlagos preferencia index alacsony volt $\left(\mathrm{E}_{\mathrm{i}}=0,11\right)$. Az egyes idószakokban azonban különbségeket lehetett tapasztalni. A vizsgálat első időszakában erdei pocok dominancia mellett és a második időszakban (erdei pocok és erdeiegér faj-együttes hasonló aránya esetén) a róka az erdei pockot az előfordulási gyakoriságával megegyező mértékben fogyasztotta. A vizsgálat harmadik idószakában (erdeiegér dominancia mellett) pedig jelentős mértékben preferálta (49. és 66. ábra).

A vizsgálat három éve alatt a róka az erdei egereket kisebb mértékben fogyasztotta (66. ábra), mint ahogy azok a kisemlős táplálék-forrásban elófordultak $\left(E_{i}=-0,14\right)$. A "mellőzés" a vizsgálat első két idôszakában kisebb mértékü, a második felében pedig jelentősebb volt. A róka a peleféléket és a cickányokat az előfordulási gyakoriságuk arányában fogyasztotta $\left(E_{i}=0,04\right.$, illetve 0,02$)$.

Frdei pocok

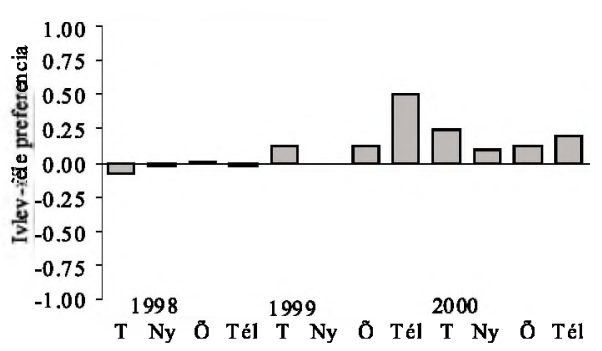

Erdeiegér faj-együttes

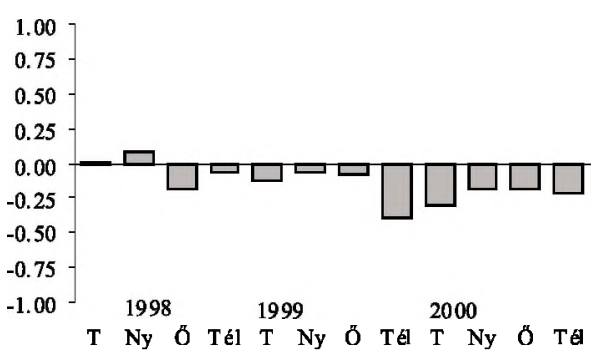

66. ábra: A vörösróka kisemlös preferenciája a Boronka-melléki Tájvédelmi Körzetben Megjegyzés: évszakok röviditése: $\mathrm{T}=$ tavasz, $\mathrm{Ny}=$ nyár, $\mathrm{O}=$ ősz 
A Kétújfalu körzetében 2001. őszén végzett kisemlős táplálékforrás felmérés eredményeinek részletesebb elemzése az aranysakálról szóló fejezetben található.

Kétújfalu körzetében a róka a mezei pockot az elófordulási gyakoriságánál nagyobb arányban fogyasztotta, vagyis előnyben részesítette $\left(\mathrm{E}_{\mathrm{i}}=0,312\right)$, míg az erdei pockot és az erdei egereket az elófordulási gyakoriságuknál ritkábban fogyasztotta, vagyis mellőzte $\left(E_{j}=-0,619\right.$, illetve $\left.-0,352\right)$. Ezek az eredmények azt mutatják, ha teheti, akkor a róka a nagyobb sűrüségben rendelkezésre álló táplálékkészletből választ, és a nyílt területen élő mezei pockot előnyben részesíti az erdei kisemlős fajokkal szemben.

\section{A vörösróka préda fajainak súlya és jellemzö élöhelye}

A különböző területeken vizsgált vörösrókák az élőhely típusától függetlenül a $15 \mathrm{~g}$ és $50 \mathrm{~g}$ közötti súlytartományba sorolt prédát részesítették előnyben (arányuk 47-70\%, 67. ábra). Ebbe a kategóriába tartozik a kisemlős fajok döntő többsége (2. melléklet). A kisemlösök egész évi nagyarányú fogyasztásával függ össze, hogy a Kétújfalu körzetében élő róka táplálékában szerepelt legnagyobb gyakorisággal a 15-50 g súlykategóriába tartozó préda. Viszonylag gyakran fogyasztottak $15 \mathrm{~g}$ alatti súlyú fajokat is (67. ábra), azonban ezek arányában jelentôs, területtől függő különbséget (0-40\%) lehetett tapasztalni. Az eredményeket befolyásolja, hogy Mike-Csököly, valamint Petesmalom körzetében élő rókák táplálékát csak téli és kora tavaszi időszakban vizsgáltam, mikor a $15 \mathrm{~g}$ nál kisebb súlyú kategóriába tartozó gerinctelenek fogyasztása még kevésbé jellemzö. A Lankóci-erdőben fordult elő leggyakrabban a kis (15 g alatti) súlytartományba eső préda fajok fogyasztása. Az 51-300 g közötti súlytartományba tartozó prédát a rókák viszonylag ritkán választották, ugyanakkor a $300 \mathrm{~g}$ feletti kategória területtól függóen eltérố mértékben (aránya 6-46\%), fontos szerepet töltött be a táplálkozásban. Ennek a "nagy" súlyú zsákmánynak az aránya Kétújfalu körzetében volt a legkisebb és MikeCsököly körzetében a legnagyobb. Ebben a kategóriában zömmel elhullott csülkös vadak és háziállatok szerepelnek, de ide tartozik például a fácán és a mezei nyúl is.

A préda súlya

A préda jellemzố előfordulása
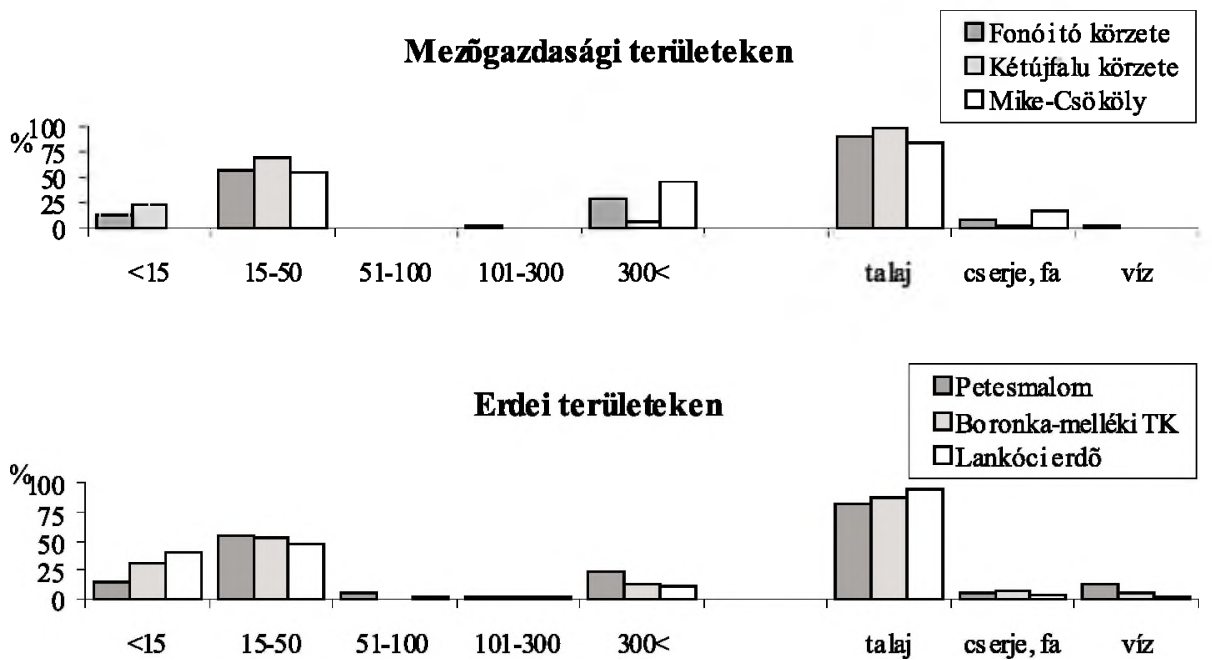

67. ábra: A vörösróka prédaválasztása a zsákmány súlya és jellemzó élőhelye szerint 
A vörösróka préda fajainak döntô többsége talajszinten élt (67. ábra), a területtől függô különbség nem volt számottevố (81-98\%). A cserjéken és fákon éló fajok fogyasztása nem jellemző a vörösrókára, ezek aránya általában alacsony volt (2-8\%). MikeCsököly körzetében a róka viszonylag gyakran fogyasztott kistestú madarakat, ezért ott rendhagyóan nagyarányú volt $(17 \%)$ a cserjeszinten élố zsákmány aránya. A vizes élöhelyhez kötődô fajok fogyasztása sem jellemző a rókára. Ezek aránya néhány százalékot tett ki, de halastavak közelében gyakoribb táplálékot jelentettek, amint azt Petesmalomban (13\%) lehetett tapasztalni.

\section{A vörösróka táplálkozási niche-szélessége}

A rókák táplálkozási niche-szélessége mezőgazdasági területeken kissé szükebb volt (68. ábra), mint erdei élöhelyen, azonban az élóhely típusától függő különbség nem volt szignifikáns $(\mathrm{P}=0,194)$. A rókák táplálkozását általában nagy táplálkozási niche-szélesség értékek jellemezték ( $B=3,16-7,31)$. Kiemelkedően magas volt az erdökkel övezett halastavak körzetében élố rókák téli és tavaszi niche-szélessége, legalacsonyabb Kétújfalu körzetében, nyári-ôszi időszakban.

A vizsgálatok alapján összességében megállapítható, hogy a vörösróka tápláléka fajokban gazdag, táplálkozási niche-e általában széles, ami táplálkozási szempontból kiváló alkalmazkodóképességet jelez. Legfontosabb táplálékát a terület jellegétól és évszaktól függốen (biomassza számítás szerint 46-85\%-ot) kisemlősök alkotják. A legtöbb hazai és külföldi hivatkozott szerző is hasonló eredményről számolt be. A meghatározó kisemlős fogyasztásból adódóan a róka sajátossága, hogy táplálékának zöme a 15 és $50 \mathrm{~g}$ közötti súlytartományba sorolható. A mezőgazdasági területeken a gazdasági kárt okozó mezei pocok, az erdei élőhelyeken pedig általában az erdei pocok a legfontosabb zsákmány faj. Ha választhat, akkor a nagyobb állománysürüségủ mezei pockot részesíti előnyben az erdei rágcsálókkal szemben. A Mike-Csököly közti területen élő róka rendhagyó módon, a téli-koratavaszi idôszakban, a kisemlôsöknél nagyobb arányban táplálkozott csülkös vaddal. A róka a téli és tavaszi időszakban jelentős szerepet tölt be a dögeltakarításban és a betegségek terjedésének meggátlásában. A róka (és a sakál) a kifejlett vaddisznót, gímszarvast és dámvadat, sôt az egészséges özet sem támadja meg, és az egészséges vad a borját, gidáját is meg tudja védeni a közepes testméretú ragadozókkal szemben. Az elfektetett borjú és gida, valamint a vadmalac viszont a ragadozók zsákmányává válhat. A területenként lényegesen eltérő mértékú, esetenként jelentôs nagyvad fo-

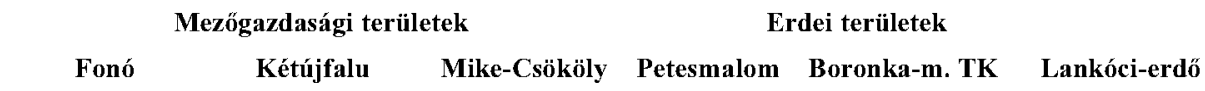

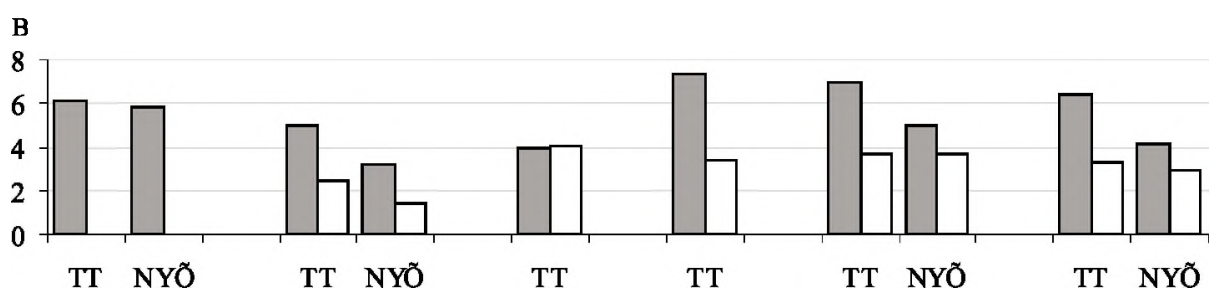

68. ábra: A vörösróka táplálkozási niche-szélessége különbözó területeken

Megjegyzés: TT= tél és tavasz együtt, NYÖ= nyár és ósz együtt; a tömör oszlop a relatív gyakoriságot, az üres oszlop a biomassza számítás alapján kapott értéket jelzi 
gyasztásban nem a predáció, hanem inkább más tényezők játszottak fontos szerepet. Így legyengüléshez és elhulláshoz vezethettek betegségek, a kemény tél, a táplálékhiány, valamint a vadászatok alkalmával a sebzést követő keresés hiányossága is. Ezen túlmenően a ragadozók a lőtt vad zsigereit is elfogyasztják (zsigerelés elvileg nem a lövés helyszínén történik), melyek maradványai szörszálakkal együtt esetenként a gyüjitött mintákban is előfordulhattak. A táplálékként leggyakoribb csülkös vad a vaddisznó, mely egész évben szerepel a róka étlapján. Ennek oka az lehet, hogy az általa okozott erdei, mezögazdasági, valamint természetvédelmi károkozás miatt a helyenként megnövekedett állománya egész évben gyéríthető (kocára van kíméleti időszak), így a fentiek értelmében fordul elő leginkább táplálékként. Az apróvad közül a mezei nyúl fogyasztása éves viszonylatban néhány tizedszázalékot tesz ki a vizsgált, nem tipikusan apróvadas jellegú mezőgazdasági és erdei területeken. A fácán részaránya egyes mezőgazdasági területeken magasabb, mint az erdei élöhelyeken, de összességében, éves viszonylatban biomassza számítás alapján részaránya a táplálékban 1-2\% körül mozog. A fácánvadászat idényében ennél nagyobb arányú az elófordulása. Vízimadarak a halastavak mentén élö rókák táplálékában fordultak elö, de éves viszonylatban, ott is csak néhány százalékos arányban. Az eredményeket befolyásolja, hogy a vizsgált halastavak természetvédelmi kezelés alatt állnak. Ezeken a területeken vízivad vadászat nem folyik, így sem kibocsátással összefüggó nagyobb állománysủrúségből, sem pedig sebzésból eredô többletfogyasztás nem fordulhatott elő. Alföldi, apróvadban gazdagabb területeken ennél jelentősebb a vadászható apróvad fajok predációja (ERDEI 1977, FARKAS 1983, HeLTAY 1989, BEGALA et al. 2000, HeLTAI et al. 2000a), azonban súlyos kártételról ott sem számoltak be.

A róka kiváló élőhelyi alkalmazkodóképességét, urbanizálódásra való alkalmasságát számos tanulmány bizonyítja (pl. DONCASTER et al. 1990). A faj jelenlétével tehát lakott területeken is egyre gyakrabban számolnunk kell. Háziállatokat, vágási maradékot és hulladékot fơként az emberi települések közelében élö rókák fogyasztanak, az összefüggó erdókben élőknél ez szinte soha nem fordul elő. A baromfi telepekre, háztáji udvarokba (akár fényes nappal is) bejáró róka megfelelő védekezés hiányában jelentős kárt okozhat, a nem szakszerúen müködtetett dögkutakról pedig betegségeket hurcolhat szét. Nyilvánvaló, hogy az egyre növekvő hazai rókaállomány erőteljes szabályozásra szorul. Jobb, ha ezt nem a különféle betegségek végzik el, melyek a háziállatokra és az emberre is veszélyesek. A gyérítés módszerei között valószínúleg nagyobb szerepet kapnak a jelenleg még kevés területen használt szelektív gyérítésre alkalmas elevenfogó ládacsapdák (SzEMETHY és HeLTAi 2000a, 2000b, 2001).

A róka kutatásával kapcsolatos további részletek az alábbi sorszámú publikációkban találhatók meg: $[6,12,13,14,15,17,18,20,21,22,23,26,27,30,31]$. 


\section{Az aranysakál}

Az aranysakál őshonos fajunk, Magyarországon egészen a XIX. század végéig rendszeresen előfordult, ameddig preferált élőhelyeinek kiterjedése drasztikusan le nem csökkent. Ebben közrejátszott a folyók szabályozása, mely a zavartalan nádasok és mocsaras területek területét csökkentette, valamint a nagy kiterjedésủ legelók feltörése és szántóföldi művelésbe vonása. Régi elnevezéseit: "nádi farkas", "réti farkas" tipikus élőhelyei alapján kaphatta. Az elsố XX. századi publikált megfigyelés az ország észak-keleti tájáról 1937-bỏl származik (ÉHIK 1938). A későbbi megfigyelések egészen a 80-as évek végéig esetiek voltak, és csak hímivarú egyedek kerültek kézre (FARAGÓ 2002). Emiatt nem lehetett bizonyítani, hogy a fajnak szaporodóképes állománya él az ország területén, ezért került az aranysakál kipusztult fajként a Vörös Könyvbe a hiúzzal és a farkassal együtt (szerk. RAKONCZAY 1989). A sakálok feltételezhető immigrációja az 1990-es évek elején a Dráva folyón keresztül zajlott, Horvátország irányából (DEMETER és SPASSOV 1993), bár a hazai, rejtve maradt populációk sem zárhatók ki teljes bizonyossággal. A bevándorló/kóborló példányok megtelepedését elösegítette a termóföldek privatizációja is. A magántulajdonba került földek egy részén a szántóföldi gazdálkodás évekig szünetel(t), ezáltal egy-egy régióban több ezer hektárnyi parlagterület is előfordulhat. Ezeken a parlagföldeken számottevő rágcsáló, elsôsorban mezei pocok állomány él (HoRvÁTH és PINTÉR 2000), valamint kedvező élőhelyi feltételeket biztosítanak a nagyvadak, valamint a szárnyas és szörmés ragadozók számára egyaránt. A zavartalan, viszonylag ritkán lakott dél-dunántúli területeken az aranysakálnak stabil állománya alakult ki, ahol a gyérítés ellenére is sikeres a szaporodása. A szaporulatból az önálló vadászatra képes egyedek egy része új élőhelyet keresve juthat el az ország távoli pontjaira, ahol szaporodóképes populációk is kialakulhatnak. Az ország egyre több pontján jelzik a sakál előfordulását (HELTAI et al. 2000d, HeLTAI 2002), de a tőlüink nyugatabbra és északabbra fekvố országokban, pl. Ausztriában, Szlovákiában és Lengyelországban is megjelentek kóborló egyedek (DEMETER és SPAssov 1993, Mitchell-JONES et al. 1999, HELL és RAJSKY 2000).

A visszatelepülés ellenére státuszát eleinte nem szabályozta semmilyen törvény. Ưjbóli megjelenésekor (elvileg) védelmet kellett volna kapnia, legalábbis az ökológiai igényének pontosabb megismeréséig. Ehelyett a faj 1997-től egész évben, korlátozás nélkül, majd 2000-től szaporodási időszakon kívül vadászhatóvá vált. Vadgazdálkodási szempontból a sakál visszatelepülése vitatott, annak ellenére, hogy ökológiai szerepét Közép-Európában eddig egyáltalán nem vizsgálták. Sajnálatos tény, hogy a médiák a sakált torzítva, a szenzáció kedvéért kedvezôtlen színben tüntették fel. Pedig a faj egyre részletesebb megismerése alapján talán Farley Mowat: Ne féljünk a farkastól (1963) híres könyvében leírt sorok eszünkbe juthatnának a sakál kapcsán (is): „...Valahonnan keletröl farkasüvöltés szállt fel, kérdö árnyalattal. Ismertem ezt a hangot, sokszor hallottam már. George faggatta a pusztaságot, s várta családja hiányzó tagjainak feleletét. De az én számomra ez a hang egy elveszett világról beszélt, amely valaha, mielótt az ellenség szerepét választottuk volna, a mienk volt ..."

A magyar vadászlapok közlése szerint a Dráva folyó közelében, a sakál hazai elterjedésének központjában 1994 és 2000 között kb. 50 példányt (AGYAKI 2000), a hazai el- 
terjedés peremterületének számító, jelen tanulmányban is szereplő Mike-Csökölyi területen, 1995 és 1996 között 8-10 példányt löttek (SIMON 1996). Az összes magyarországi vadászható faj terítékadatait nyilvántartó Országos Vadgazdálkodási Adattár szerint, 1997 és 2000 között összesen 130 egyed került terítékre, alapvetően Baranya, Somogy és Bács-Kiskun megyékben (CsÁNYI 1999, 2000, 2001, HeLTAI et al. 2000d).

A faj ismeretlensége miatt kissé részletesebb leírást adok, ugyanis előfordul, hogy az aranysakált terepen, vagy terítéken sem ismerik fel és kutyával vagy rókával tévesztik össze. Kétségtelen, hogy bizonyos hasonlóság mindkét esetben lehetséges. A kutyafélékhez tartozó aranysakál 7-15 kg kifejlettkori súlyt ér el, testhossza $80-100 \mathrm{~cm}$, farka rövid: 20-25 cm (REICHHOLF 1983, TRENSE 1989, MitchelL-Jones et al. 1999). Szórzete dús, tapintása durva, színezete a barnás-vörhenyestől a szürkés-feketéig bármilyen árnyalatú lehet. Hasa szürkésfehér, hátán sötét sáv fut végig. Feje keskeny, arcorri része megnyúlt, koponyája nem nagyobb lényegesen a rókáénál. Az arányosan rövid hegyes fülei a fejtetőn, egymástól távol helyezkednek el (DEMETER és SPASSOV 1993). A füleket kívülről vöröses szôr borítja, ellentétben a rókával, melynek fekete a fül külső oldala. Szeme ferde vágású (FARAGó 1994). Fején a szörzet általában barna színú, pofája és a torok piszkos fehér. A tömör, rövid farok vége sötét színủ (DEMETER és SPASSOV 1993), ellentétben a fehér farokvéggel rendelkező rókával. Fontos határozóbélyeget jelent a mancs, ugyanis a két középső ujjpárna mind a négy mancson részlegesen összenőtt. Ez a jellegzetesség a farkasnál, a rókánál, vagy a kutyánál nem fordul elő (FARAGó 2002).

A kotorékot vagy maga készíti, vagy már kész róka, illetve borz várat foglal el (DEMETER és SPASSOV 1993). Sok esetben nem készít kotorékot, hanem jól elrejtett vackot épít bozótosokban, nádasokban (DEMETER és SPASSOV 1993). Ezt támasztják alá a hazai hivatásos vadászok (BEck T., Gellai T., Kolozsi G. és SzÜLE P.) megfigyelései is.

A sakál fơként éjszaka és szürkületben jár táplálék után, a nappalt átjárhatatlan bozótosokban vagy kotorékban tölti. Főként vadászútra indulásakor hallható a csoport elnyújtott, hullámzó, esetenként hiéna "vihogására" hasonlító, de egyedenként is eltérő hangokból álló üvöltése. A farkashoz hasonlóan kórust alkotnak, amely a territórium határjelzését és a csoport összetartását is szolgálja. A hangjelzésre a szomszédos családi csoportok szinte azonnal válaszolnak. Szociális életük fejlettsége a farkasokét megközelíti. A sakál életre szóló párkapcsolatban él, a kölykök nevelésében a hím is részt vesz. A pár territóriumán belül csak a domináns $\alpha$ nőstény és domináns $\alpha$ hím szaporodik, ezek kölykeinek nevelésében "segít" a territóriumon belül maradt, előző évi lányutóduk. Ez az un. segítô egyed is részt vesz a kölykök táplálékkal való ellátásában és védelmezésében. Ezt a nevelési stratégiát alloparentális utódgondozásnak nevezzük, mely révén a kölykök felnevelése sikeresebb (MACDONALD 1983, GERLAI és BARABÁs 1991). Ez a magatartás ritkán a vörösrókánál is előfordul (MACDONALD 1979).

Az európai állományokban a párzási időszak januártól márciusig tart, a vemhesség 60 62 nap. A kölykezés márciustól május elejéig tart, az átlagos alomlétszám 3-5, de ritkán akár 8 kölyök is elöfordulhat (HELTAI és SzÚCS 2002). A 12-15 napig vak kölykök két hetes korukig csak tejet szopnak. A továbbiakban előemésztett táplálékot is fogyasztanak. Ebben az esetben a zsákmányt a szülók nem a szájukban cipelik a kotorékhoz vagy vacokhoz, hanem fogyasztanak a prédából, majd a kölyköknek a gyomruk tartalmát kiöklendezik. Ezt a kölykök ajaknyalogató viselkedése váltja ki. Két hónapos korukig szopnak és addig a kotorék közelét sem hagyják el. A következő év tavaszán hagyják el szüleik territóriumát, kivéve egyes nőstényeket, melyekből segítő egyed válik. A nőstények már az első évükben, a hímek kétévesen válnak ivaréretté.

Az ürítésnek - a farkashoz hasonlóan - igen fontos szerepe van a territórium határainak jelölésében (Peters és Mech 1975, Harrington és Mech 1979, Macdonald 1980, 1983). A sakál az ürítést az esetek döntő többségében a territórium határán végzi, míg a rókánál ez nem kifejezetten jellemző. Gyakori, hogy több sakál ürülék is egymáshoz kö- 


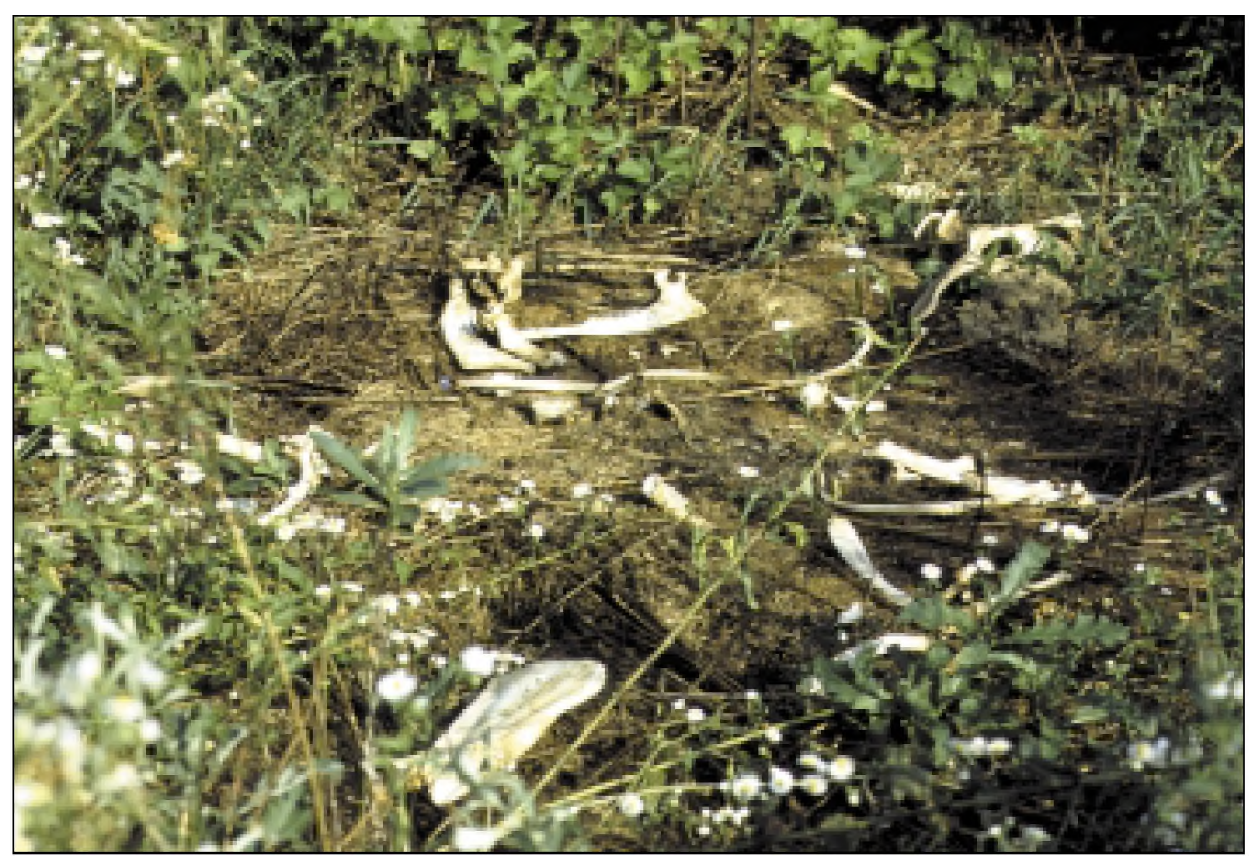

69. ábra: Orvvadász áldozatául esett (hurkolt) gímszarvast téptek szét az aranysakálok (Canis aureus)

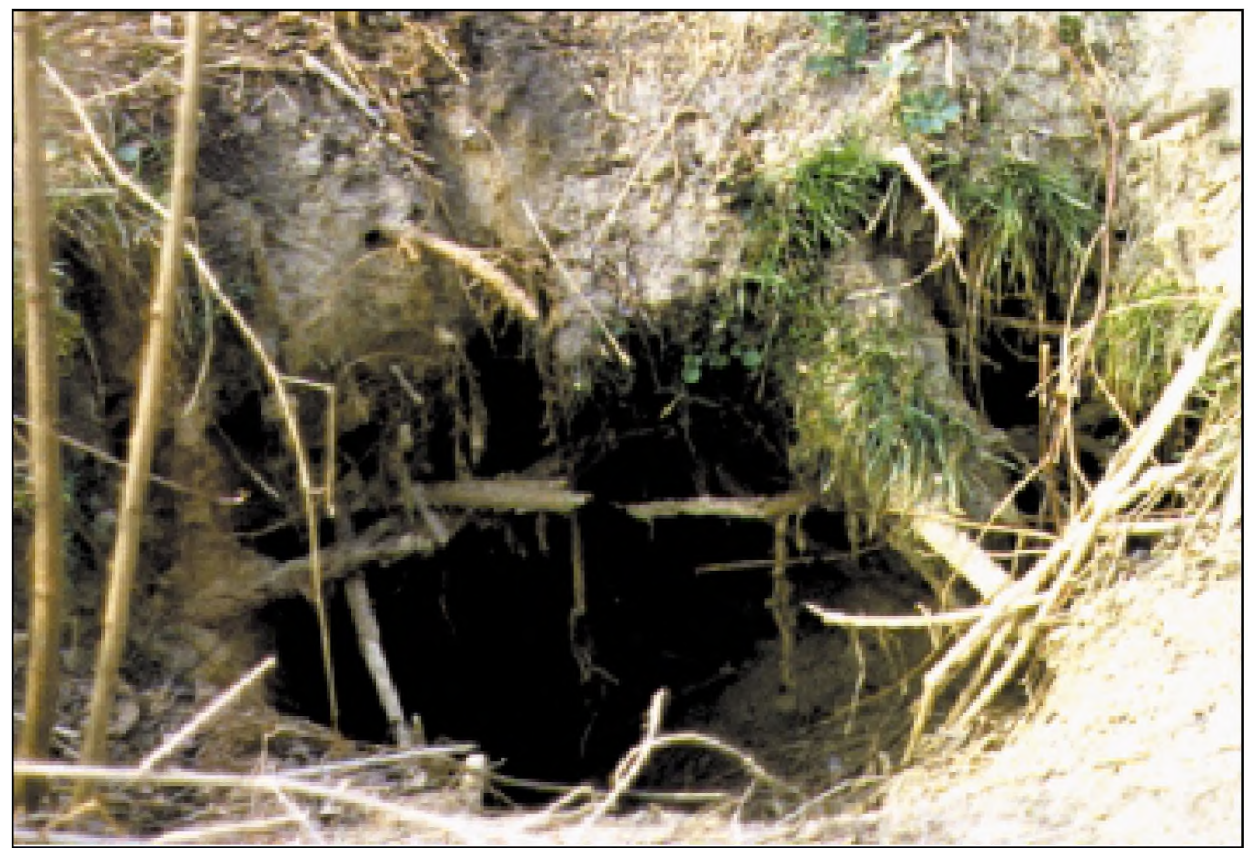

70. ábra: Aranysakál kotorék kijárata 


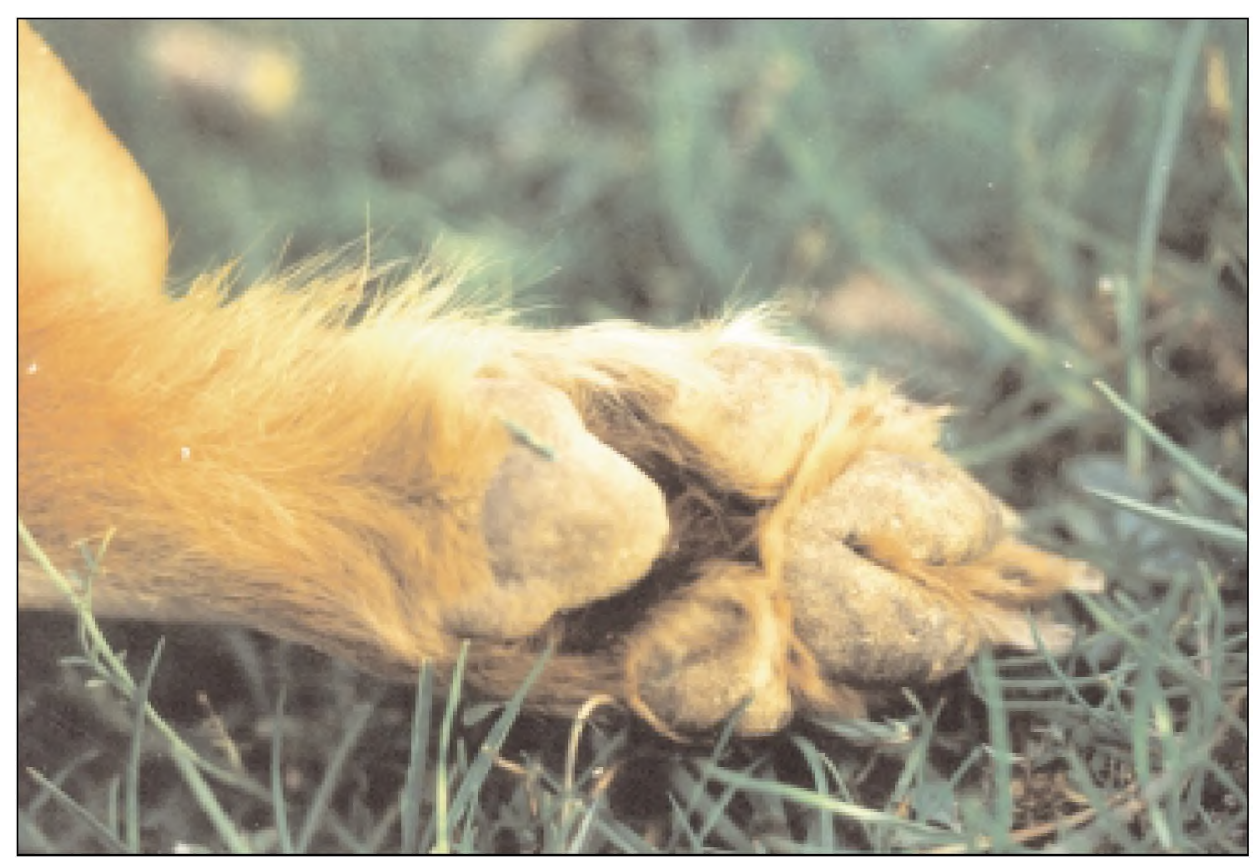

71. ábra: Az aranysakál talpa. Faji jellegzetesség, hogy második és harmadik ujjpárnája részben összenőtt

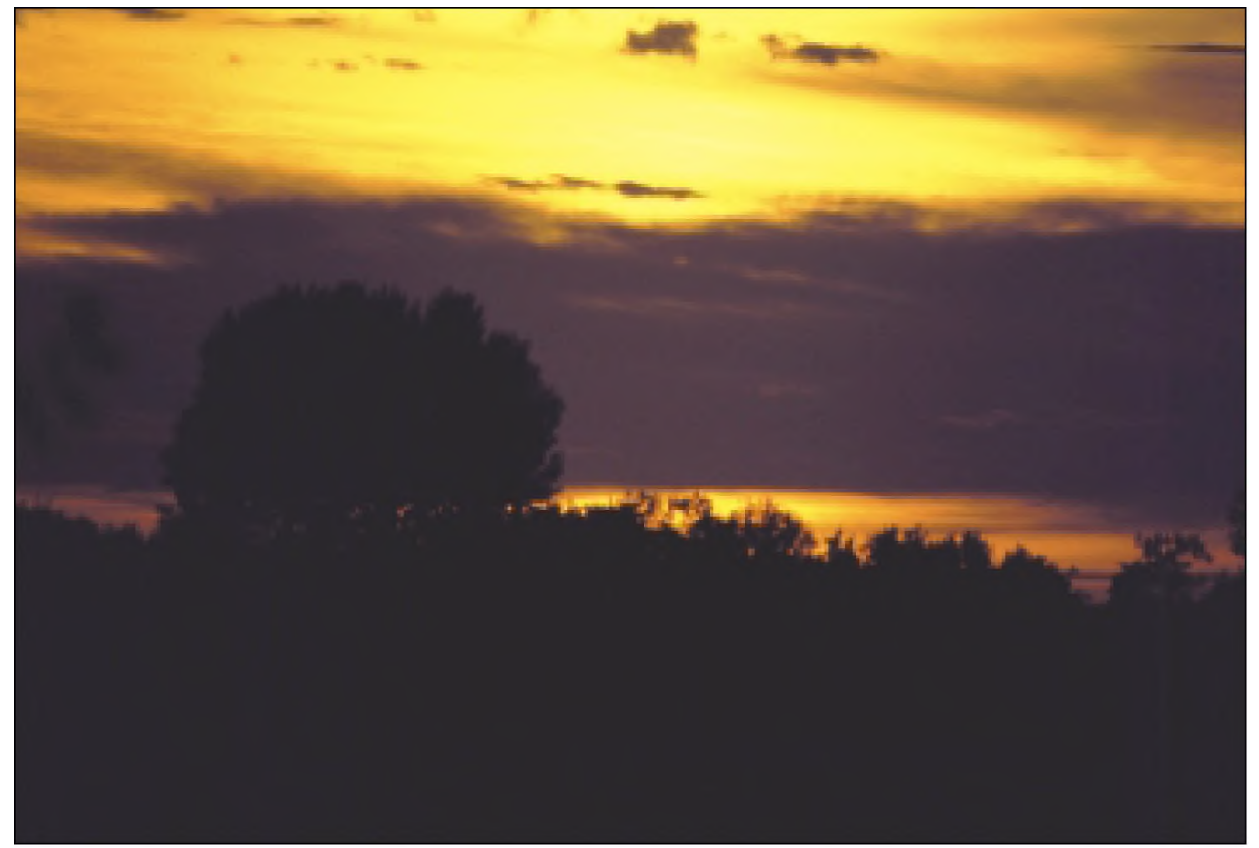

72. ábra: Naplemente az Ormánságban 
zel található, ugyanez a rókánál ritkán fordul elő (MACDONALD 1980). Ezeket a különbségeket elsősorban a faj hazai elterjedésének központjában lehetett jól megfigyelni. Hazai megfigyelés szerint (GELLAI 2002) a családi csoport territóriuma 2,5-4 km².

Élőhelyét Afrikában a füves szavanna jelenti, más területeken a fás legelőket, bokorerdóket, bozótos, nádas és parlagterületeket, a háborítatlan élőhelyeket kedveli. Állandó, szaporodóképes állománya farkastól mentes területeken lehetséges (MITCHELL-JoNES et al. 1999).

Az aranysakál vadászati stratégiájáról és táplálék-összetételéről csak néhány dél-kelet európai, ázsiai, valamint kelet- és észak-afrikai vizsgálati eredmény áll rendelkezésre. Az irodalom e tekintetben (LAMPRECHT 1978, GiTTLEMAN 1985, 1989, MACDONALD és BARRETT 1993), különösen a közép-európai régióban, erősen hiányos. Táplálékában a kis testű préda fajok, elsősorban a rágcsálók és a madarak dominálnak (LiTVINOV 1979, IsHUNIN 1980). A Bulgáriában élő sakálok télen főleg dögevők, még a fajtársuk tetemét is elfogyasztják, ezen kívül növényeket, pl. füféléket, málnát, gabonát és egyéb magvakat találtak táplálékukban (ATÁNASSOv 1953). Kazahsztáni vizsgálatokban 75 különbözó táplálék taxon fordult eló az étlapján (TARYANNIKOV 1974), köztük például halak, hüllök és kétéltúek. Afrikában végzett megfigyelés alapján kígyófogyasztást is leírtak (LAWICK 1970). Kazahsztáni vizsgálatok szerint a sakál táplálékának 68-84 \%-át emlösök, föleg rágcsálók alkotják (IsHUNIN 1980). Más vizsgálatokban nyulat, fácánt, vízivadat és tojásokat is találtak a táplálékában (GIDAJATOV 1965, DemETER és SPASsov 1993). Esetenként jelentős háziállat és nagyvad borjú fogyasztást írtak a rovására (STENIN et al. 1983, DemeTER és SpAssov 1993). A háziállat (juh, kecske, sertés, baromfi) állományban való pusztítás valószínű okaként a sakálok gyors európai térhódítását jelölték meg (STENIN et al. 1983). Izraeli vizsgálat szerint a sakálok képesek a legelön tartott szarvasmarha borját zsákmányul ejteni (YoM-Tov et al. 1995). Feltételezések szerint a nagyvad állományban elsősorban a fiatal őzgidát és a dám borjakat veszélyezteti (STENIN et al. 1983). Objektív vizsgálatok szerint a sakál a rendelkezésre álló táplálékból jellemzően magányos vadászat során választ. Viszonylag rövid lábai miatt kitartó futásra kevésbé képes, mint a farkas, ezért inkább lesből támad (ALIEV 1969, LAWICK 1970, TARYANNIKOV 1974, LAMPRECHT 1978). Zsákmányszerzése tehát jellemzóen magányos vadászat során zajlik, de előfordul a párban és esetenként - az utódok vadászatra tanítása idején - a családi csoportban történő vadászat is (összefoglalta BEKOFF et al. 1984, GITTLEMAN 1989). Ekkor 3-7 egyed látható együtt, a csoportot a domináns szülöpár és kölykeik alkotják. A Serengeti Nemzeti parkban, Kelet-Afrikában, nyílt terepen végzett megfigyelés szerint (LAMPRECHT 1978) az aranysakálok kétszeresen sikeresebben ejtettek el kifejlett Thomson gazellát párban, mint magányosan, de a sikeresség aránya ekkor is mindössze $32 \%$ volt. A zsákmányból gyorsan, nagy mennyiséget képes elfogyasztani a nagyobb testü ragadozók ( $\mathrm{pl}$. hiéna) jelenléte miatt, melyek a prédáról elüzik a kisebb ragadozókat. Elószeretettel fogyasztja el a dögöket, illetve a nagyobb ragadozók, vagy vadászok által elejtett vad maradványait, vagy a sebzett vadat is.

Hazai tapasztalatok szerint (Kétújfalu körzete, GELLAI 2002) a sakálok 90 -es évek elején tapasztalt megjelenését követốn a vadászterület ózállománya 2-3 évig csökkent, majd a következő évben a kiinduló létszám kb. 80\%-át elérve stagnált. Az ôzek testtömege a sakál megjelenése óta (10 év alatt) mindkét ivarban közel $2 \mathrm{~kg}$-ot nött, ezt követte a trófea tömegének növekedése is. Az elmúlt években több kiváló minőségú bakot tudtak lövetni, mint a korábbi évtizedekben ott, ahol a sakálok a természetes kiválogatódásban résztvettek. A rekord trófeával (564 gramm) rendelkező őzbak is a sakálos terület kellős közepén élt. A különleges trófeákra pedig nagyobb kereslet van, mint az átlagosakra. A vadászterület értékét tehát növeli a sakálok jelenléte. Nagyon érdekes a sakálnak az emberhez füződő viselkedése is. Települések közelébe csak hideg, ködös időben merészkednek, de akkor sem törnek be oda (GELLAI 2002). Hivatásos vadászok (GELLAI T és KoLOzSI G.), valamint a terepi munkáink során tapasztaltak szerint a sakál 
általában jobban tart az embertől, mint a róka. Az esti szürkületkor elhangzott lövésrekülönösen, ha a lött vad hangot hallat - szinte azonnal reagálhatnak üvöltésükkel. Életrevalóságukat mutatja, hogy a megsebzett, de az éjszaka meg nem talált vadat a rókánál és a hajnalban keresésre induló vadásznál előbb megtalálják. Megjegyzem, ezeknek az egyedeknek a maradványai azután ugyanúgy megjelennek a sakál hullatékokban, mintha a táplálék predációból származott volna.

\section{Az aranysakál táplálék-összetétele különbözö területeken}

A vizsgálatok mezögazdasági területeken zajlottak, így a sakál hazai (pontosabban dél-dunántúli) elterjedésének peremén, valamint a hazai elterjedés központjában.

\section{Az aranysakál hazai elterjedésének peremén}

A Mike-Csököly körzetében élő sakál téli és kora-tavaszi táplálékában az elsődlegesen fontos kisemlősök fogyasztott biomassza aránya $56 \%$ volt (73. ábra, 16. melléklet). A kisemlósök közül a mezei pockot fogyasztotta a legnagyobb mennyiségben, de ezen kívül erdei pocokkal, valamint erdei egérrel is táplálkozott. A mezei nyúl fogyasztása 0,3 $\%$-ot tett ki.

Az elhullott csülkös vadak másodlagosan fontos szerepet játszottak a sakál téli-tavaszi táplálkozásában, fogyasztott biomasszájuk aránya 41\%-ot tett ki (73. ábra, 16. mel-

\begin{tabular}{|c|c|c|}
\hline Tél & Tavasz & Nyár \\
\hline & & \\
\hline
\end{tabular}

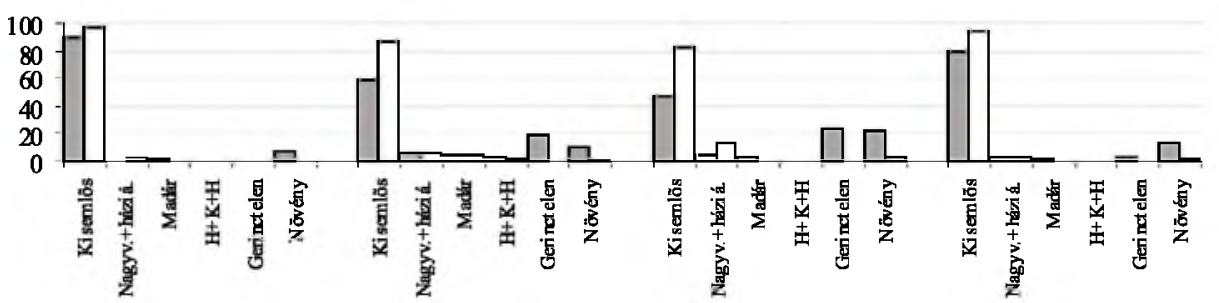

Tél - kora tavasz
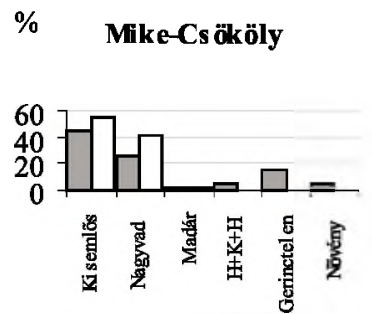

73. ábra: Az aranysakál táplálék-összetétele a hazai elterjedés központjában és peremén Megjegyzés: Nagyv.+háziá. = nagyvad és háziállat egyuutt; $\mathrm{H}+\mathrm{K}+\mathrm{H}=$ hülló, kétéltú és hal együtt; a tömör oszlop a relatív előfordulási gyakoriságot, az üres oszlop a biomassza számítás szerinti értéket jelenti 
léklet). Szarvasfélék (gímszarvas, dámvad és őz) a vaddisznónál nagyobb gyakorisággal fordultak elö, mégis ez utóbbi biomasszája volt a meghatározó a táplálékban.

Háziállatot és halat nem fogyasztott a sakál, a madarak (kistestú énekesmadarak), a hüllők (gyíkok) és kétéltűek szerepe jelentéktelen volt (73. ábra, 16. melléklet). Ízeltlábúak közül futóbogarakat és lótücsköt viszonylag gyakran $(16 \%)$, de kis biomassza számítás szerinti részesedéssel $(0,4 \%)$ fogyasztott. Növények közül kukorica és füfélék fordultak elő a táplálékában, de szintén jelentéktelen mennyiségben (73. ábra, 16. melléklet).

A Mike-Csököly körzetében vizsgált aranysakál és a vörösróka táplálék-összetétele nem különbözött szignifikánsan ( $\mathrm{P}=0,117)$. Vagyis a területen élő sakál, majd az azt felváltó róka a rendelkezésre álló táplálékforrásokat hasonló arányban hasznosította.

\section{Az aranysakál hazai elterjedésének központjában}

Az aranysakál hazai elterjedésének központjában, Kétújfalu körzetében az elsődlegesen fontos táplálékot minden évszakban a kisemlősök jelentették (73. ábra, 16. melléklet). A kisemlósök fogyasztott biomasszájának aránya - bármely más vizsgált ragadozó emlőshöz viszonyítva - évszaktól függetlenül szúk tartományban mozgott és kiemelkedően (!) magas volt (83-97\%). A kisemlősökhöz képest bármelyik más táplálék csoport szerepe elenyésző volt. A sakál a legkevesebb rágcsálót nyáron, a legtöbbet télen fogyasztotta. A télen fogyasztott kisemlősök aránya közel kétszerese volt, mint az aranysakál hazai elterjedésének peremén élóknek (73. ábra, 16. melléklet). A kisemlösökön belül a mezei pocok jelentette a fó táplálékot (biomasszája 56-83\%), de emellett nagy gyakorisággal fordultak elő táplálékként különböző erdei egerek és erdei pocok is. Ritkán cickányféléket és mogyorós pelét is zsákmányolt. Mezei nyúl fogyasztás a kritikus téli és tavaszi időszakban egyáltalán nem fordult elő. Nyáron átlagosan $0,1 \%$ és ősszel is $2 \%$ alatt maradt a nyúl fogyasztott biomasszájának aránya.

A csülkös vadak fogyasztott biomasszájának aránya évszakonként 2,5 és 5,5\% között mozgott (73. ábra, 16. melléklet). Télen és ősszel a vaddisznó, az év többi részében a szarvasfélék jelentettek fontosabbak táplálékot. A csülkös vad fogyasztása valójában tavasz végén és nyáron emelkedett meg; ez a szarvasfélék ellési és utódnevelési időszaka. Ekkor a sakálok az újszülött, illetve a néhány napos és néhány hetes elfektetett, vagy elpusztult borjakból és gidákból is fogyaszthattak. A fiatal egyedeket a róka is képes lefojtani, csak ez ritkábban fordul elő (14. melléklet). A sakál a tavasz végi és nyár elejei időszakban a beteg, legyengült gidákat és borjakat csalhatatlanul képes kiszemelni és azokat zsákmányul is ejti. Viszont az év többi részében feltételezhetô, hogy többségében elpusztult vadból táplálkozhattak. A területen végzett terepi megfigyelés szerint az őzsuta a sakált elkergeti (!) gidája közeléből. A legelö vad pedig még a fejét sem emeli fel, amikor közelében haladnak el sakálok, vagy felhangzik az üvöltésük (GELLAI T., KoLOzSI G.). Téli időszakban a nagyvadak részaránya elenyészően alacsony volt a hazai elterjedési peremterületen élö sakálhoz (vagy általában bármely terület rókaállományához) viszonyítva. Mindezek az adatok világosan jelzik, hogy a sebzett vad keresése a vadászok részéről itt valóban hatékonyan zajlott.

A háziállatok nyáron szerepeltek számottevő arányban, ekkor fogyasztott biomasszájuk megközelítette a $10 \%$-ot. A táplálékként előfordult macska dögből (lótt, vagy autó által elgázolt), de akár zsákmányolásból is származhatott. A szarvasmarhát és sertést kizárólagosan dögkút közelében fogyaszthatták (73. ábra, 16. melléklet), a vizsgált területen legeltetés nem folyt. Egyetlen esetben sem lehetett kimutatni juhfogyasztást, pedig az elsó vizsgálati évben a mintagyüjitési területen keresztül gyakran hajtottak át birkanyájat. Éppen itt "vádolták" a tulajdonosok a sakálokat a nyáj tizedelésével.

A madártáplálékon belül a fácán bizonyult a legielentősebbnek (73. ábra, 16. melléklet). Fogyasztott biomasszájának aránya a tavaszi költési időszakban számottevő (4\%), 
az év többi részében jelentősége elenyésző volt $(0,5 \%$ alatt). A terület fácánállománya a jelenlevố predátor fajok ellenére is erôteljes, gyarapodó, mivel ezek számára sokkal könnyebben hasznosítható, rágcsálókból álló táplálék-forrás áll rendelkezésre.

Hüllők, kétéltủek és halak, bár előfordultak a sakál táplálékában, nem játszottak fontos szerepet. Leginkább a tavaszi kölyöknevelés időszakában fogyasztottak belölüik.

A gerinctelenek különösen tavasszal és nyáron fordultak elő a táplálékban gyakran és nagy fajgazdagsággal (73. ábra, 16. melléklet), fogyasztott biomasszájuk viszont kicsi volt $(0,2-0,3 \%)$. A tavasz vége és a nyár a kölykök tanulásának időszaka; feltételezhetô, hogy a vadászati módszerek elsajátításának része az alacsonyan repülő rovarok (pl. cserebogarak, sáskák) elkapása.

A növények - a rókánál tapasztaltakkal ellentétben - fontosabb szerepet csak nyáron és ősszel töltöttek be (73. ábra, 16. melléklet). Fogyasztott biomasszájuk aránya azonban még a vadon termő gyümölcsök érésének időszakában is meglehetösen alacsony maradt (2-3\%).

A Kétújfalu körzetében élő sakál és róka tápláléka nem különbözött szignifikánsan sem a téli-tavaszi $(\mathrm{P}=0,934)$, sem a nyári-őszi időszakban $(\mathrm{P}=0,722)$.

\section{Az aranysakál kisemlős preferenciája}

A kisemlős táplálék-forrás felmérése Kétújfalu körzetében 2001. októberében, parlagföldön és erdőben zajlott (részletes leírás az anyag és módszer fejezetben található). A vizsgált parlagterületen, a kisemlősök legkisebb ismert egyedszáma alapján számított biomasszája $5,66 \mathrm{~kg}$ és az erdőben $3,25 \mathrm{~kg}$ volt hektáronként. A kisemlős fajok százalékos megoszlását a 74. ábra szemlélteti.

Az aranysakál a mezei pockot kifejezetten preferálta $\left(\mathrm{E}_{\mathrm{i}}=0,326\right)$. Ez azt jelenti, hogy a környezetében rendelkezésre álló kisemlős forrásból nagyobb arányban fogyasztotta, mint annak a készleten belüli részaránya, vagyis kereste ezt a préda fajt. Ezzel szemben

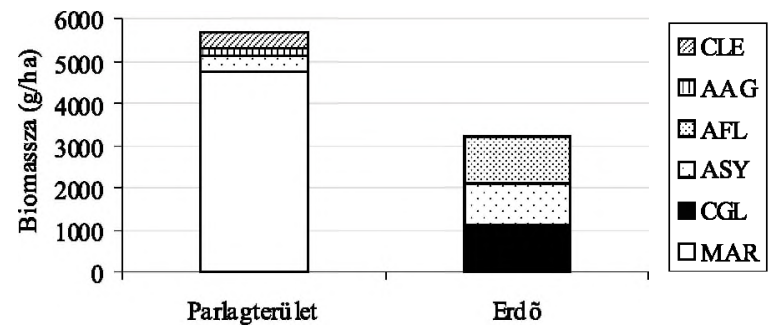

74. ábra: A kisemlős fajok biomasszája Kétújfalu körzetében (2001 ősz)

Jelmagyarázat: CLE - mezei cickány, AAG - erdei pirókegér, AFL - sárganyakú erdeiegér, ASY - közönséges erdeiegér, CGL - erdei pocok, MAR - mezei pocok

az erdei pocok $\left(E_{i}=-0,766\right)$ és az erdeiegér $\left(E_{i}=0,587\right)$ fajok preferencia indexe negatív. A főként erdei élőhelyhez kötődő kisemlősök esetén tehát jellemző a mellőzés.

A preferencia indexek, valamint a két élöhely típus lényegesen eltéró fajösszetétele alapján megállapítható, hogy a vizsgált időszakban a sakál elsősorban a nagyobb rágcsáló sürüségü, nyílt területen szerezte zsákmányát, mint az erdőben. 
Az aranysakál préda fajainak súlya és jellemzố élóhelye

Az aranysakál jellemzően 50 g-nál kisebb súlyú prédát fogyasztott. A faj hazai elterjedésének peremén ennek aránya összesen $71 \%$, az elterjedési központjában pedig $94 \%$ volt (75. ábra) A Mike-Csököly körzetében élö sakál téli-koratavaszi idôszakban vizsgált táplálékában jelentôs volt a $300 \mathrm{~g}$ feletti préda gyakorisága is (29\%), melybe fóként elhullott nagyvadak tartoztak. A Kétújfalu körzetében élő sakál az 50 és $300 \mathrm{~g}$ közötti súlytartományba tartozó fajokat 1\%-ban, a 300 g feletti prédát pedig 5\%-os arányban fogyasztotta.

A sakálok élớhelytől függetlenül, szinte kizárólag (98\%-ban) talajszinten élő prédával táplálkoztak (75. ábra).

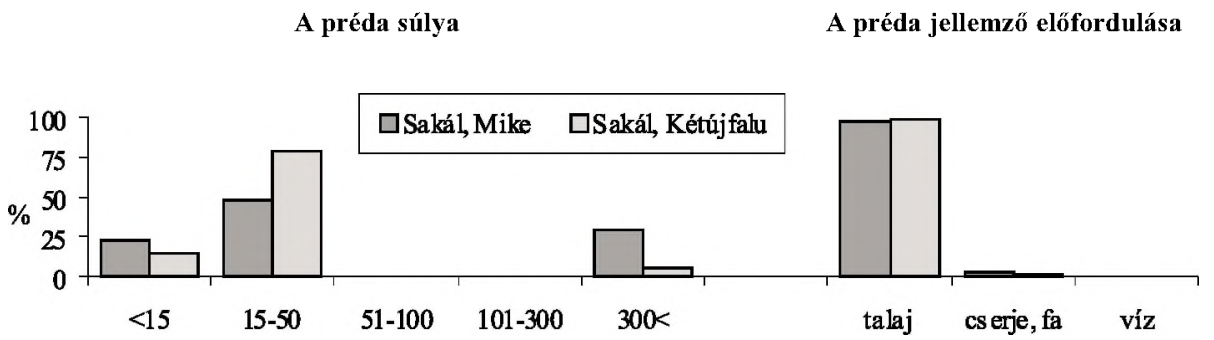

75. ábra: Az aranysakál prédaválasztása a zsákmány súlya és jellemző élőhelye szerint

Az aranysakál táplálkozási niche-szélessége

A faj hazai elterjedésének peremén élô egyedek téli-tavaszi táplálkozási niche-szélessége $(5,19)$ kétszerese volt (76. ábra) az elterjedési központban élő sakálénak $(2,7$, illetve 2,56). Ez azzal függ össze, hogy a peremterületen élő sakál tápláléka kiegyenlítettebb volt a fố táplálék csoportok százalékos megoszlása alapján. A központi területen élő populáció táplálékának döntő részét kisemlősök alkották, ennek köszönhetően szűk volt a táplálkozási niche-szélességüik. Az adatok alapján a peremterületen inkább generalista, míg a központi területen „kisemlős specialista“ táplálkozásmód jellemezte a fajt.

Mike- Csököly

Kétújfalu

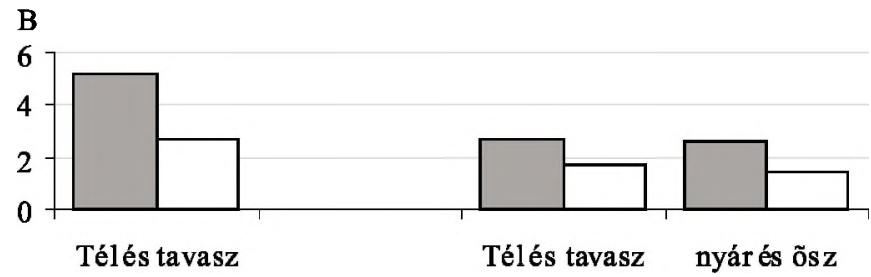

76. ábra: Az aranysakál táplálkozási niche-szélessége a faj elterjedésének peremén és központjában

Megjegyzés: a tömör oszlop jelzi a relatív gyakoriságot, az üres oszlop a biomassza számítás alapján kapott élrtéket 
Összességében megállapítható, hogy a hazai elterjedés központjában található területen, ahol a parlagföldek, árokpartokat szegélyezö bokros és fás élóhelyek, valamint a szabdalt erdők túlsúlya jellemző, a kisemlősök fogyasztása közel kétszerese a vizsgált mezőgazdasági mủvelés alatt álló peremterületen élő sakálénak. A peremterületen télitavaszi idôszakban az elhullott csülkös vad fogyasztása volt jelentôs (amint az ott élố rókánál is). Mivel az ürülék mintákban elöfordult vaddisznó, illetve szarvasfélék maradványai kifejlett egyedektől származtak, a predációnál valószínúbb a dögfogyasztás. A vizsgálat ezen a területen tavasszal megszakadt a sakálok eltünése miatt, ezért nem lehet tudni, vajon a szarvasfélék ellési időszakában hogyan alakult volna a táplálék-összetétel. A központi területen télen nem volt jelentôs a nagyvadak fogyasztása, viszont tavasz végén és nyár elején, a nagyvadak ellési és utódnevelési időszakában megnőtt a fogyasztásuk. Azonban ekkor is előfordult dögfogyasztás (adult vaddisznó és gímszarvas). Kétséget kizáróan nagyvad fajok borjának zsákmányolását írták le Afrikában (LAWICK 1970), Ázsiában (összefoglalta: DEMETER és SPASSOV 1993), valamint magas hóban óz és dámvad elejtéséról is beszámoltak (DEMETER és SPASsov 1993). A szavannán az aranysakál általában magányos vadász, esetenként párban vadászik gazellák borjára (LAWICK 1970, LAMPRECHT 1978). A jelen peremterületi vizsgálatban, téli-koratavaszi periódusban viszont kizárható a nagyvad borjak zsákmányolása is. A területen nyári-öszi időszakban, családi kötelékben történt vadászatot figyeltek meg dámvadra és vaddisznó süldőre (SIMON 1996, SzÜCs Z. szóbeli közlés) és Afrikában is leírtak hasonló eseteket (LAMPRECHT 1978). A hosszan tartó üldözés azonban nem jellemzó az aranysakál vadászati stratégiájára, ugyanis testfelépítése alapján elsősorban a préda gyors lerohanására alkalmas (LAMPRECht 1978, TrENSE 1989, DemETER és SPAssov 1993). Európában, a sürün lakott vidékeken, az ember általi üldözés miatt inkább a magányos vagy páros vadászatot részesítik előnyben a falkavadászattal szemben (DEMETER és SPASSOV 1993).

A szakirodalomban közöltekhez hasonlóan a vizsgált területen kisemlős és nagyvad fajok mellett sok egyéb táplálék taxon is előfordult a sakálok táplálékában. Más szerzők is beszámoltak például halak, kétéltüek (ALIEV 1969, TARJANNIKOV 1974), gyümölcsök és egyéb növények (ALIEv 1969, LAWICK 1970, LAMPRECHT 1978, DEMETER és SPASSOV 1993 ) fogyasztásáról. A jelen vizsgálati eredményektől eltérően, Ázsiában jelentős apróvad predációról (DEMETER és SPASSOV 1993, GIDAJATOV 1965), valamint háziállat fogyasztásról is beszámoltak (STENIN et al. 1983, YOM-Tov et al. 1995). Apróvad a hazai sakálok táplálékában nem jelentős mennyiségben fordult elö, háziállat fogyasztás pedig „dögkútból“" történt.

Közép-Ázsiában a táplálék nagyfokú változatosságát, valamint jelentős évszakonkénti különbséget tapasztaltak (DEMETER és SPASSOv 1993). A jelen vizsgálatok ettől részben eltérnek. A központi területen ugyanis a táplálék egyhangúságát (a kisemlősök abszolút túlsúlyát) jelezték az alacsony táplálkozási niche-szélességi értékek is. A táplálék összetétele alapján a vizsgálatban szereplő aranysakál kisemlős specialista életmóddal jellemezhetô. Ugyanakkor a peremterületen kapott eredmények azt mutatják, hogy a sakál jól képes alkalmazkodni más élőhelyi feltételekhez is, amennyiben az emberi zavarás mértéke nem jelentős. Képes az éppen legkönnyebben kiaknázható táplálékforrást kihasználni, ami táplálkozási opportunizmusra utal. Nyilvánvaló, hogy a vizsgálatban szereplő néhány év tapasztalata alapján még nem lehet kimerítő választ adni a sakál hazai táplálkozási szokásairól. Ennek ellenére a kapott eredmények sejtetik, hogy egy rendkívül sokszínü, érdekes, valószínúleg még sok meglepetéssel szolgáló ragadozó fajjal állunk szemben. Az adatokból remélhetően az is kiolvasható, hogy a sakál hazai megítélése méltatlanul negatív.

Az aranysakál kutatásával kapcsolatos további részletek az alábbi sorszámú publikációkban találhatók meg: $[21,22,23,26,27]$. 


\section{Fajok közötti táplálkozási kapcsolatok}

A ragadozók interspecifikus táplálkozási kapcsolatait mélységeiben elemző vizsgálatok száma meglehetősen kevés. Ennek oka, hogy időigényes és célszerűen a fontosabb táplálékforrások sưrúségviszonyait és a zsákmányállatok populációdinamikáját befolyásoló fơbb környezeti és más élőhelyi tényezőket is egyidejüleg kellene vizsgálni, mindezt bonyolult matematikai-statisztikai módszerek alkalmazásával. Komplex vizsgálatot ezért ritkán végeznek, ehelyett csak néhány fontosabb tényező hatását tanulmányozzák.

Például a mediterrán éghajlatú területen élő borz és a róka közötti táplálkozási kapcsolatot hullaték-analízissel vizsgálva azt tapasztalták (CIAMPALINI és LovARI 1985), hogy a két faj közötti táplálkozási niche-átfedés nagymértékü $(80 \%)$ volt. Ennek oka, hogy mindkét faj táplálékát fóként rovarok és gyümölcsök alkották, még a téli hónapokban is. A kisemlösök és madarak fogyasztása a vemhesség és szoptatás idószakában volt jelentős. Videokamerás megfigyelőrendszer segítségével BuEsCHING és MACDONALD (1998) figyelemmel követte az egy területen éló róka és borz táplálkozási szokásait és a közöttük felmerülő kompetíciót. Azt tapasztalták, hogy a két faj között nincs közvetlen interspecifikus kompetíció (pl. küzdelem). Ehelyett a dominancia viszonyok döntik el a táplálékszerzés sorrendjét. Eszerint a rókák táplálékfogyasztása szignifikánsan csökkent a borzok jelenlétében.

Jelentős (70\%-os) táplálkozási niche-átfedést tapasztaltak mediterrán területen a róka és a nyest között is (SERAFINI és LOVARI 1993, BRANGI 1995). Szerzők véleménye szerint a fajok közötti kompetíciót mérsékelte, hogy mindkét faj táplálékában jelentős szerepet töltöttek be a gyümölcsök, melyek nem számítanak korlátozó tényezőnek a ragadozó emlősök számára. Közép-európai mezógazdasági területen ennél jelentôsebb niche-átfedést tapasztaltak (GosZCZYNSKI 1986) a róka és a nyest között (70-90\%). A két faj közötti versengés jelentős volt a kisemlösökből álló táplálékforrás hasznosításáért.

Lengyelországban, a Bialowieza-i Nemzeti Parkban a farkas, a hiúz, a róka, a nyestkutya, a menyét, a hermelin, a nyuszt (és több más ragadozó emlős és madár) táplálékösszetételét és táplálkozási niche-átfedését vizsgálták hullaték-analízissel (REIG és JEDRZEJEWski 1988, JEDRZEJEWskA és JEDRZEJEWski 1998). Azt tapasztalták, hogy a farkas és a hiúz téli- kora tavaszi időszakban nagyvadra specializálódott (fóleg szarvasféléket és vaddisznót fogyasztott), táplálkozási niche-átfedésük $100 \%$-os volt. Hasonló megállapításra jutottak a kisemlősökre specializálódott, kistestű menyét és hermelin esetében (97\%-os átfedés). A szélesebb táplálékspektrumú, közepes testméretủ ragadozók fơ táplálékát kisrágcsálók képezték, táplálék-összetételük közepes mértékben fedte egymást (45-55\%). A hermelin és a róka között 40\%-os, a nyuszt és a róka között 45-55\%os, a borz és a többi ragadozó között alacsony, $10 \%$ körüli átfedést kaptak. A farkas, illetve a hiúz és a róka között 48-55\%-os, a nagyragadozók és a nyuszt között mindössze 2-7\%-os volt a táplálkozási niche-átfedés. A vidra és a szárazföldi ragadozó fajok közötti átfedés alacsony (20\% alatti), az amerikai nyérccel viszont nagymértékú volt (81-97\%).

Ebben a fejezetben külön tekintem át a vizes élőhelyekhez kötődő vidra populációk, és külön a szárazföldi ragadozók populációi közötti táplálkozási kapcsolatokat. Arra keresek választ, hogy a fajspecifikus, táplálkozással összefüggố tulajdonságok a fajok (ill. populációik) összehasonlító vizsgálatakor milyen mértékű hasonlóságot, illetve különb- 
ségeket mutatnak. Továbbá vizsgálom, hogy jelentősebb kompetíció esetén, az életközösségben való együttélésben milyen tényezók játszhatnak szerepet, hogyan valósulhat meg a táplálék-források felosztása és a prédaválasztás.

\section{Vidra populációk összehasonlító vizsgálata}

\section{A vidra táplálékának változatossága és niche-szélessége különbözó élöhelyeken}

A vizsgálatok szerint a vidra táplálékspektruma viszonylag széles. A feldolgozott minták alapján például a Fonói halastavon élő vidra 47 zsákmány- és 5 növény-, a Boronkamelléki Tájvédelmi Körzetben 30 zsákmány- és 4 növény-, Petesmalomban 48 zsákmány- és 4 növény-, a Lankóci-erdőben 25 zsákmány- és 1 növény-, a Tetves-patakon élő vidra 26 zsákmány- és 1 növény taxonhoz tartozó táplálékot fogyasztott.

Az aktuális vidratáplálék változatosságának egyfajta mércéje az egy mintára jutó táplálék taxonok száma is lehet, melyet a táplálék-összetételt tartalmazó táblázatokban (3., 7., 8. és 10 . melléklet) $\mathrm{k} / \mathrm{n}$ felirat jelez. A vizsgált élőhelyek döntő többségében a $\mathrm{k} / \mathrm{n}$ értéke jellemzően 1,4 és 2,0 között mozgott. A vidra tápláléka eszerint meglehetôsen egyhangú. Azonban néhány élőhelyen ennél lényegesen magasabb értéket lehetett tapasztalni, így például nyári-ôszi időszakban Babócsán, az Ó-Dráván (3,0), és a Barcs-Komlósdi Rinyán $(7,0)$ viszonylag sokféle táplálék taxon szerepelt a mintákban.

A sokféle táplálék fogyasztása mellett a vidra fajspecifikus tulajdonsága, hogy bőséges halállomány esetében szük a táplálkozási niche-e. Ennek oka, hogy fó táplálékát a halak jelentik. A 77. ábrán a vizsgált élőhelyeken élő vidrák niche-szélessége szerinti rangsor látható. Az oszlopok az évenkénti téli-tavaszi, valamint nyári-őszi időszakok átlagait jelentik, ezen kívül az átlag szórása (s.e.) is látható. A felső negyed (75\% fölött) a széles, az 50-75\% a közepesen széles, a 25-50\% a közepesen keskeny és a $25 \%$ alatti negyedbe a keskeny niche értékkel jelzett vidra élóhelyek tartoztak.

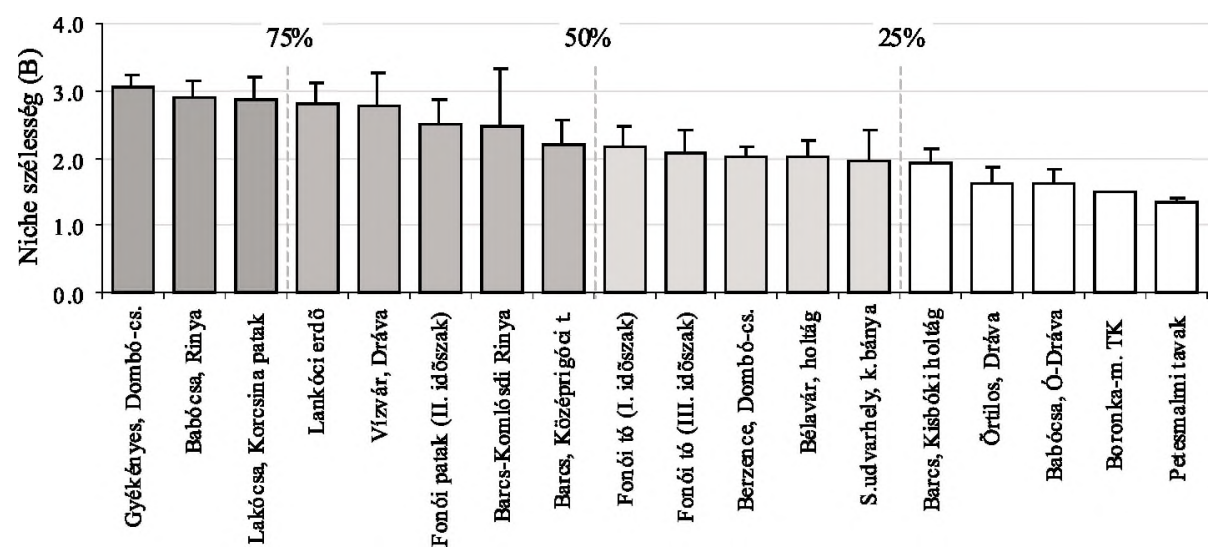

77. ábra: A vidra táplálkozási niche-szélessége különbözỏ élőhelyeken 
A halastavakon és a horgászattal hasznosított holtágakon általában szủk a vidra táplálkozási niche-e, mivel ott a halkészlet böséges (77. ábrán). A patakokon és csatornákon a táplálkozási niche szélesedik, mert a táplálékban az egyébként másodlagosan fontos táplálék taxonok (kétéltủek, madarak) szerepe nő. A 77. ábrán bejelölt vonalak csak tájékoztató jellegúek, ugyanis a területek között éles határ nem húzható meg. Az élöhelyek minósítésekor a szórás adatok is fontos jelzésként szolgálnak. A vidráról írt fejezetben már szerepelt, hogy bizonyos élóhelyeken jelentős időszaktól függő niche-szélesség ingadozás volt tapasztalható. Ez azt jelzi, hogy a vidra táplálék-készletében, és/vagy más élőhelyi feltételben jelentős változások, problémák merültek fel. Kiugróan nagy szórás tapasztalható például a Barcs-Komlósdi Rinyán, ahol a vízfolyás időszakosan kiszárad. Továbbá azokon a területeken is problémák merülhetnek fel, ahol a part mentén húzódó vegetáció szabdalt és az emberi zavarás is jelentős (Somogyudvarhely), vagy ahol nagy a vízszintingadozás és emellett az emberi jelenlét is rendszeres (pl. nyáron a Dráván). Ráadásul ezeken a területeken a vidrasürüség is viszonylag alacsony (26. ábra). Kis szórás tapasztalható egyes természetvédelmi kezelésben levő területeken, így a Boronkamelléki Tájvédelmi Körzet tavain, vagy a petesmalmi halastavakon. A vidrák normális életritmusát itt az emberi behatások - a többi területhez viszonyítva - kismértékben módosítják, pl. állandó haltáplálék-forrással rendelkeznek, a partközelben nincs állandó zavaró emberi jelenlét.

\section{A különbözó élöhelyeken éló vidrák táplálékának hasonlósága}

A különböző élőhelyeken élő vidrák összevont, éves táplálékának hasonlóságát cluster-analízissel vizsgáltam. A 78. ábrán az ágak (elágazások) távolságát relatív skála jelzi, ugyanis a dendogram alapját képező mátrix, Pearson korrelációszámításon alapul és ennek értéke -1-től +1-ig terjedhet. A táplálék taxonok ugyanazok, melyeket a niche-szélesség számításoknál is alkalmaztam.

A dendogram (78. ábra) alapján három fó élőhely csoport különült el. Az első csoportba mindössze az időszakosan kiszáradó és alacsony táplálék-forrással rendelkezö Korcsina-csatorna sorolható. Az időszakos kiszáradással összefügg a vidrasűrüség éven be-

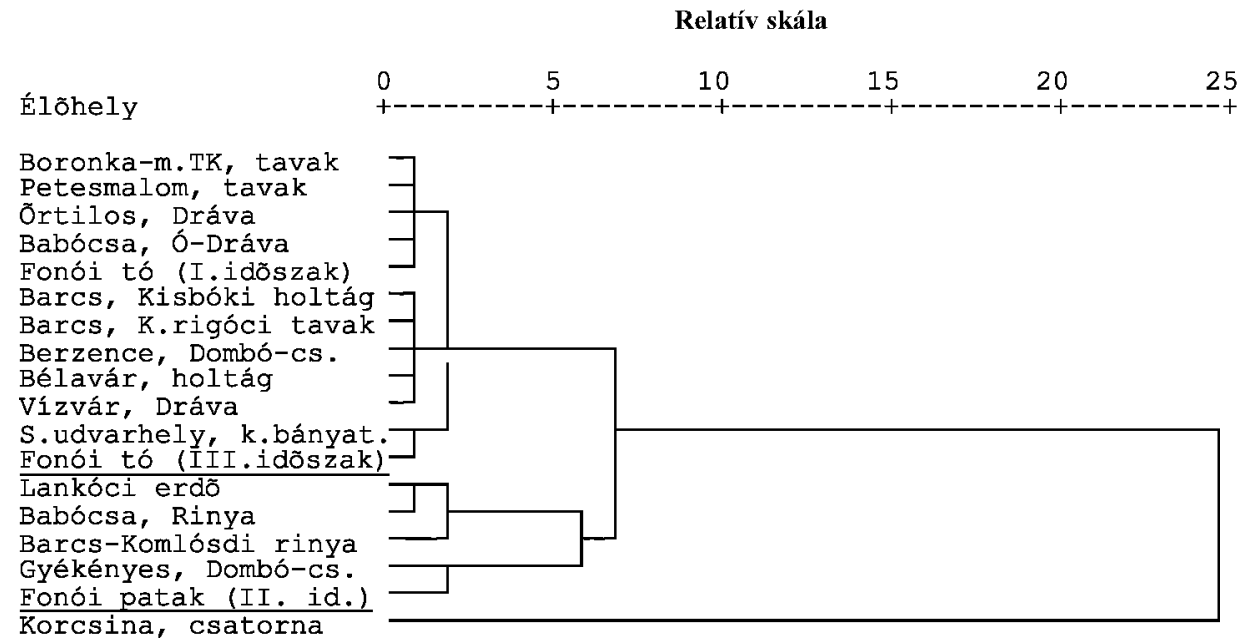

78. ábra: A különböző élőhelyeken élő vidrák táplálékának hasonlósága 
lüli nagymértékủ ingadozása is (26. ábra). A második csoportba az időszakosan kiszáradó vagy alacsony vízhozamú, de alkalmilag jelentôs hal-, vagy kétéltú-forrással jellemezhetó élóhelyek tartoznak. A harmadik csoportba a bóséges haltáplálék készlettel rendelkező élőhelyek: a Dráva folyó, a holtágak és tavak tartoznak, ezek többsége horgászati, vagy halászati hasznosítás alatt is áll.

\section{Ragadozók interspecifikus kapcsolatai}

\section{A szárazföldi ragadozó fajok táplálékának változatossága és niche-szélessége}

A szárazföldi ragadozó emlősök táplálékspektrumában nagy különbségek tapasztalhatók. A vizsgált fajok között legkisebb testméretú a hermelin tápláléklistája egyben a legrövidebb. A Fonói tó körzetében éló hermelin 18 préda- és 4 növény-, a Lankóci-erdőben mindössze 11 préda- és 1 növény taxonba tartozó táplálékot fogyasztott. A közepes testméretű fajok tápláléka lényegesen változatosabbnak bizonyult. A nyest sokféle táplálékot fogyasztott, így a mezőgazdasági környezetben élő 55 zsákmány- és 17 növény-, az urbánus nyest 35 zsákmány- és 19 növény taxont. Az erdőlakó nyuszt táplálékspektruma is széles: a Boronka-melléki Tájvédelmi Körzetben 62 zsákmány- és 11 növény-, a Lankóci-erdőben 49 zsákmány- és 8 növény taxon fordult elő. A borz tápláléka élőhelytől függően kevesebb, vagy több táplálékféleséget tartalmazott. Mezőgazdasági területen mindössze 25 zsákmány- és 6 növény-, erdei élöhelyen viszont 47 préda- és 11 növény taxon fordult elô táplálékként. A vörösróka kapesán vizsgált területek közül csak azokat sorolom fel, melyekröl egész évre vonatkozó adatok álltak rendelkezésre. A mezőgazdasági területeken élő rókák táplálék taxonjainak száma nagy hasonlóságot mutatott, így a Fonói tó körzetében 42 zsákmány- és 12 növény-, a Kétújfalu körzetében élőnél 40 zsákmány- és 10 növény taxon szerepelt. Az erdei környezetben élő rókák tápláléklistáján az előzőeknél általában több taxon fordult elő, így a Boronka-melléki Tájvédelmi Körzetben 66 zsákmány- és 15 növény-, a Lankóci-erdőben pedig 47 zsákmányés 8 növény taxon. A vizsgált legnagyobb testú faj az aranysakál. A Kétújfalu körzetében egész évben vizsgált sakál tápláléka fajokban gazdag, 45 zsákmány- és 9 növény taxon fordult elö étlapján. E tekintetben a sakál hasonlónak bizonyult a mezőgazdasági területeken élő rókához.

Az egy mintára jutó taxonok száma is érdekesen alakult (10,-16. melléklet). A hermelin tápláléka egyhangú, mert az $\mathrm{k} / \mathrm{n}$ értéke téli és tavaszi időszakban alig több egynél $(1,1-1,3)$, de nyáron és ỏsszel sem tapasztalható kiugróan magas érték $(1,4$, illetve 1,7$)$. Ezzel szemben a mezốgazdasági környezetben élố nyest aktuális tápláléka változatosabb, éves átlagban értéke 2,0, az urbánus nyesté 3,1. A nyusztnál az egy mintára jutó taxonok száma a nyesthez hasonló (1,9-2,7). A borznál viszont ennél magasabb értékek tapasztalhatók, így a Fonói tó körzetében 2,9 és 4,3, a tájvédelmi körzetben pedig 3,9 és 7,0 között alakult az aktuális táplálék változatosságának mérőszáma. A vörösróka tápláléka e tekintetben a nyesthez, illetve a nyuszthoz hasonló, az egy mintára jutó taxonok száma 1,8 és 3,2 között mozgott. Az aranysakálnál ez az érték lényegesen kiegyenlítettebb és nagyobb is volt $(3,4-3,8)$, mint a rókánál. Ez azonban abból adódott, hogy egyegy hullatékban akár 8-10 rágcsáló példány is eloofordulhatott, míg a rókánál a számítás alapját képezó minimális egyedszám gyakran mindössze egy volt. A vizsgált fajok többségének tápláléka általában tavasszal és nyáron vált változatosabbá. 
79. ábra: Szárazföldi ragadozó emlősök standartizált táplálkozási niche szélessége Relatív előfordulási gyakorisági adatok alapján

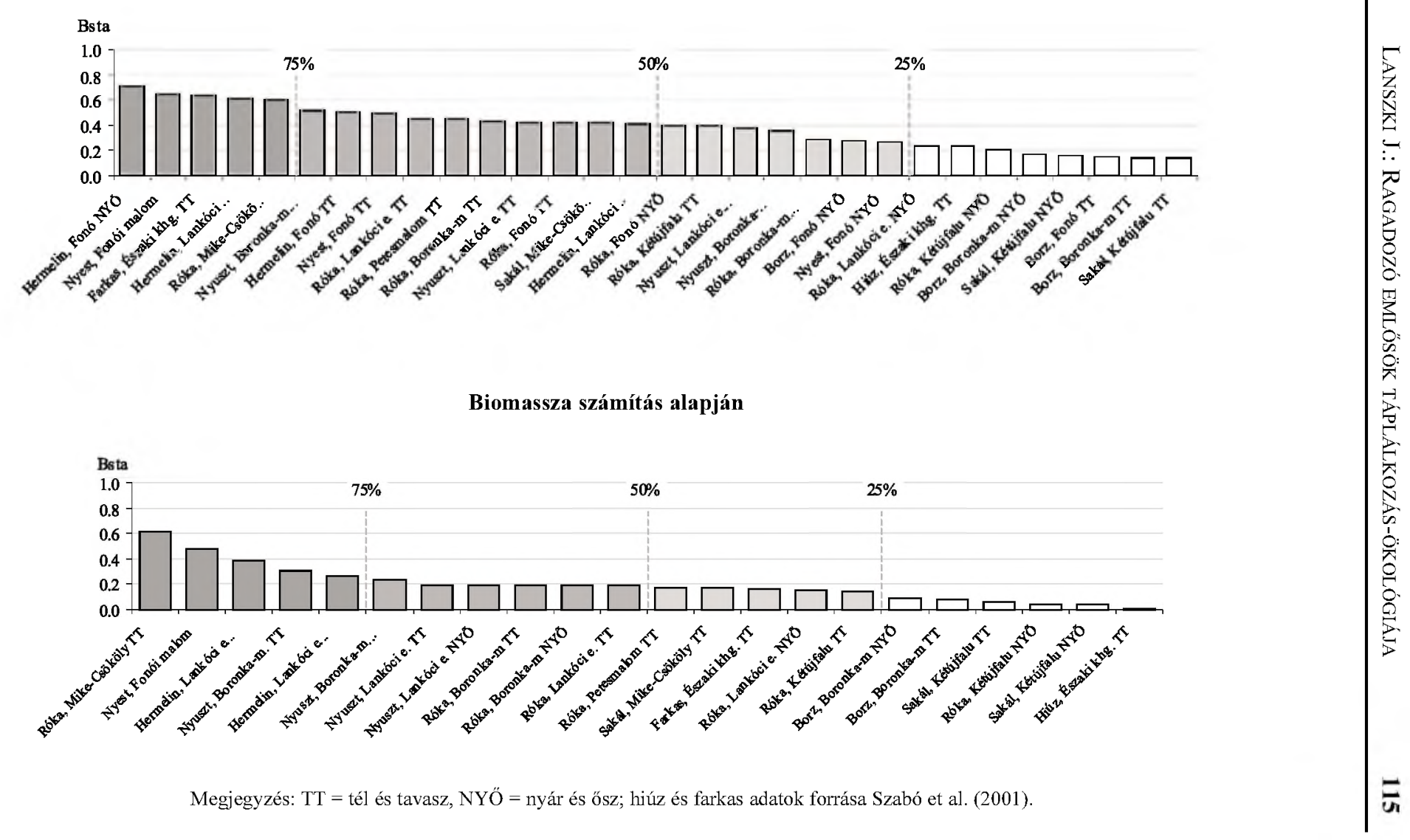


A 79. ábrán a vidrához hasonló módon rendezve látható a szárazföldi ragadozók táplálkozási niche-szélessége. A elófordulási gyakorisági adatokon túl a biomassza számítás alapján kapott rangsort is feltüntettem. A fajok és területek összehasonlíthatósága érdekében standardizált adatok szerepelnek, melyek értéke 0 és 1 között változhat. Ez a számításmód az egyes fajoknál külön-külön ismertetettektől akár eltérố tendenciát is mutathat, ugyanis itt a viszonyítás lehetôségének a kihasználása a fó cél. Az összehasonlításban az Eszaki-középhegységben élő farkas és hiúz is szerepel (részletesebben: SzABó et al. 2001), melyeknél a mintafeldolgozás módszere megegyezett a többi ismertetett ragadozónál leírtakkal.

A kvartilisek szerinti negyedeket jelölö határvonalak a szárazföldi ragadozóknál is csak tájékoztató jellegủek lehetnek, mivel a fajok táplálkozási szokásai között éles határ nem húzható meg. Viszont az előfordulási gyakorisági adatokon alapuló rangsor esetében feltünő, hogy fajtól és élöhelytöl függetlenül az 50\% feletti niche-szélesség tartományban elsősorban téli-tavaszi időszak, az 50\% alatti tartományba pedig nyári-őszi időszak szerepel (79. ábra). Vagyis a standardizálás alapján tendenciaszerú, hogy adott faj, adott élőhelyen a téli és tavaszi időszakban szélesebb táplálkozási niche értékkel rendelkezik, mint a nyári és őszi időszakban. Kivételek azonban előfordulnak, például a borz időszaktól függetlenül szük, a hermelin pedig széles niche-sel jellemezhető.

A biomassza számítási adatokon alapuló standardizálással a fajok (és élőhelyek) közötti különbségek jobban kifejezésre jutnak (79. ábra). Az 50\% feletti kvartilis tartományba, azaz a szélesebb niche tartományba tartozott a hermelin, a nyest, a nyuszt, valamint a róka a Boronka-melléki Tájvédelmi Körzetben, részben a Lankóci-erdőben, valamint Mike-Csököly körzetében. Az 50\% alatti, keskeny niche tartományba sorolható a farkas, a hiúz, a borz, a sakál, valamint a róka Kétújfalu és Petesmalom körzetében, továbbá nyári-ôszi időszakban a Lankóci-erdốben. A standardizált niche-szélesség adatok alapján (79. ábra) táplálékspecialistának nevezhető a hiúz, a borz, valamint a sakál, hazai elterjedésének központjában. A nyest és a nyuszt a niche-szélessége szerint generalista, a vizsgált rókák többsége pedig átmeneti helyet foglal el a szélsőséges esetek között. A hermelin a monoton táplálék-összetétele miatt, még a széles táplálkozási niche-e ellenére sem nevezhető generalista fajnak. A táplálék-összetétel más szempontú rendezésével (pl. cluster analízis) együttesen különíthetôk el a szélsőséges specialista és a generalista fajok.

\section{Szárazföldi ragadozó fajok táplálék-összetételének hasonlósága}

A szárazföldi ragadozók táplálék-összetételének hasonlóságát összevont téli-tavaszi, valamint nyári-őszi időszakban, külön-külön is vizsgáltam. Ugyanazt a 15 táplálék taxont alkalmaztam, melyeket a niche-szélesség számításoknál.

A téli és tavaszi előfordulási gyakorisági és biomassza számítási adatok alapján látható (80. ábra), az ábrán alulról, a legnagyobb különbségeket mutató kapcsolatoktól felfelé haladva, hogy táplálék-összetételét tekintve lényegesen elkülönült az urbánus nyest. További elkülönülő faj a gilisztával és kétéltủekkel táplálkozó borz, a nagyvadakkal táplálkozó hiúz és farkas. E fajok tápláléka általában egymástól is jelentősen különbözött. A Mike-Csököly körzetében éló róka tápláléka hasonlított a hiúzéhoz (nagyvad dominancia). A többi faj tápláléka, terïlettől függetlenül kisebb-nagyobb mértékủ hasonlóságot mutatott és további, egyértelmủ elkülönítéseket a relatív előfordulási gyakoriság adatok nem tettek lehetővé.

Biomassza számítás alapján viszont jellegzetes a Mike-Csököly körzetében élő vörösróka és aranysakál táplálékának egymáshoz való nagyfokú hasonlósága és elkülönülése a többi csoporttól. 
Relatív elốfordulási gyakoriság számítás alapján

Relatív skála
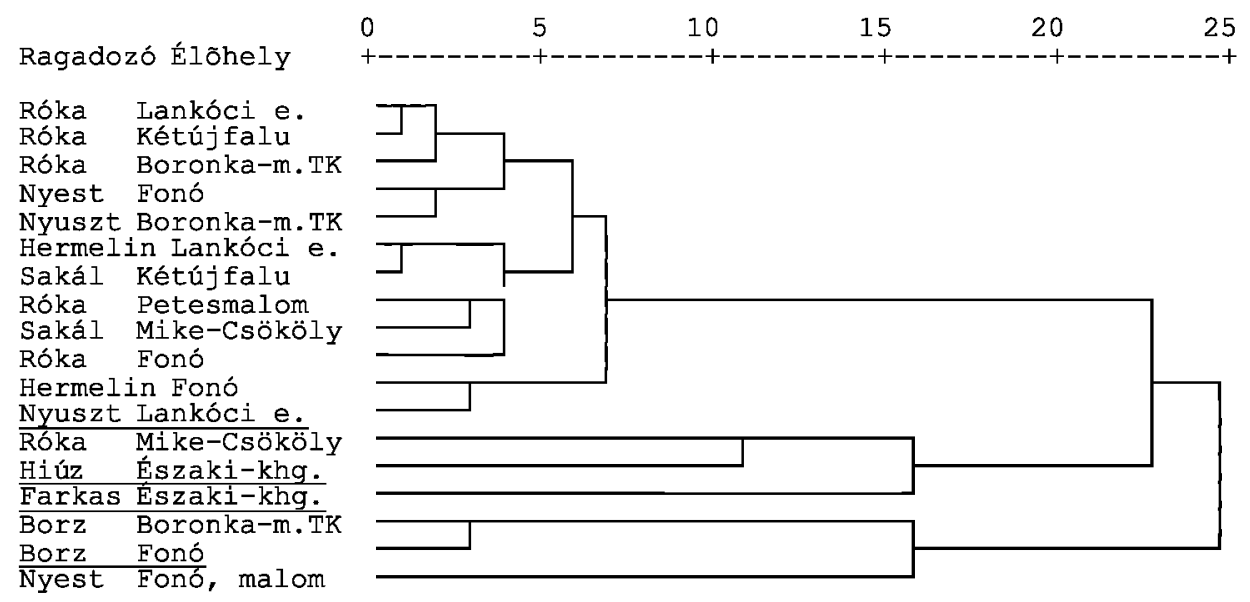

Biomassza számítás alapján

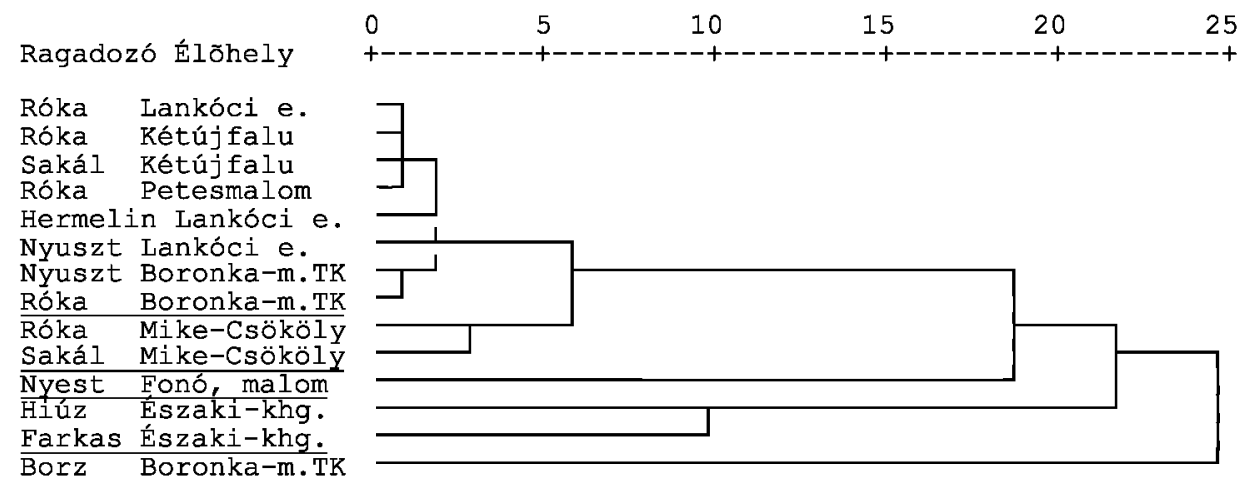

80. ábra: Szárazföldi ragadozók táplálék-összetételének hasonlósága téli-tavaszi idôszakban

* farkas és hiúz adatok forrása: SzABó et al. (2001)

A nyári és öszi táplálék-összetétel alapján (81. ábra) a többi fajtól lényegesen elkülönült az erdei borz, valamint a Fonói tó körzetében élő hermelin. Szintén jelentôsen különbözött az élőhely jellegétől függetlenül a nyest, továbbá előfordulási gyakorisági adatok alapján a Lankóci-erdőben, és biomassza számítás alapján a Boronka-melléki Tájvédelmi Körzetben élő nyuszt. Érdekes csoportba sorolás látható az előfordulási gyakoriság alapján végzett számításnál. Ugyanis a Kétújfalu körzetében, mezőgazdasági területen vizsgált sakál és róka táplálékához hasonlónak bizonyult a Fonói tó körzetében élö róka, valamint a Lankóci-erdóben élő hermelin tápláléka is. Hasonlóképp figyelemre méltó, hogy biomassza számítás alapján a Kétújfalu körzetében élő sakálhoz és rókához került közeli besorolásra a Lankóci-erdőben élö nyuszt és hermelin. Ezt a csoportosítást az egyes fajoknál kapott, korábban leírt eredmények is alátámasztják. 


\section{Relatív elốfordulási gyakoriság számítás alapján}

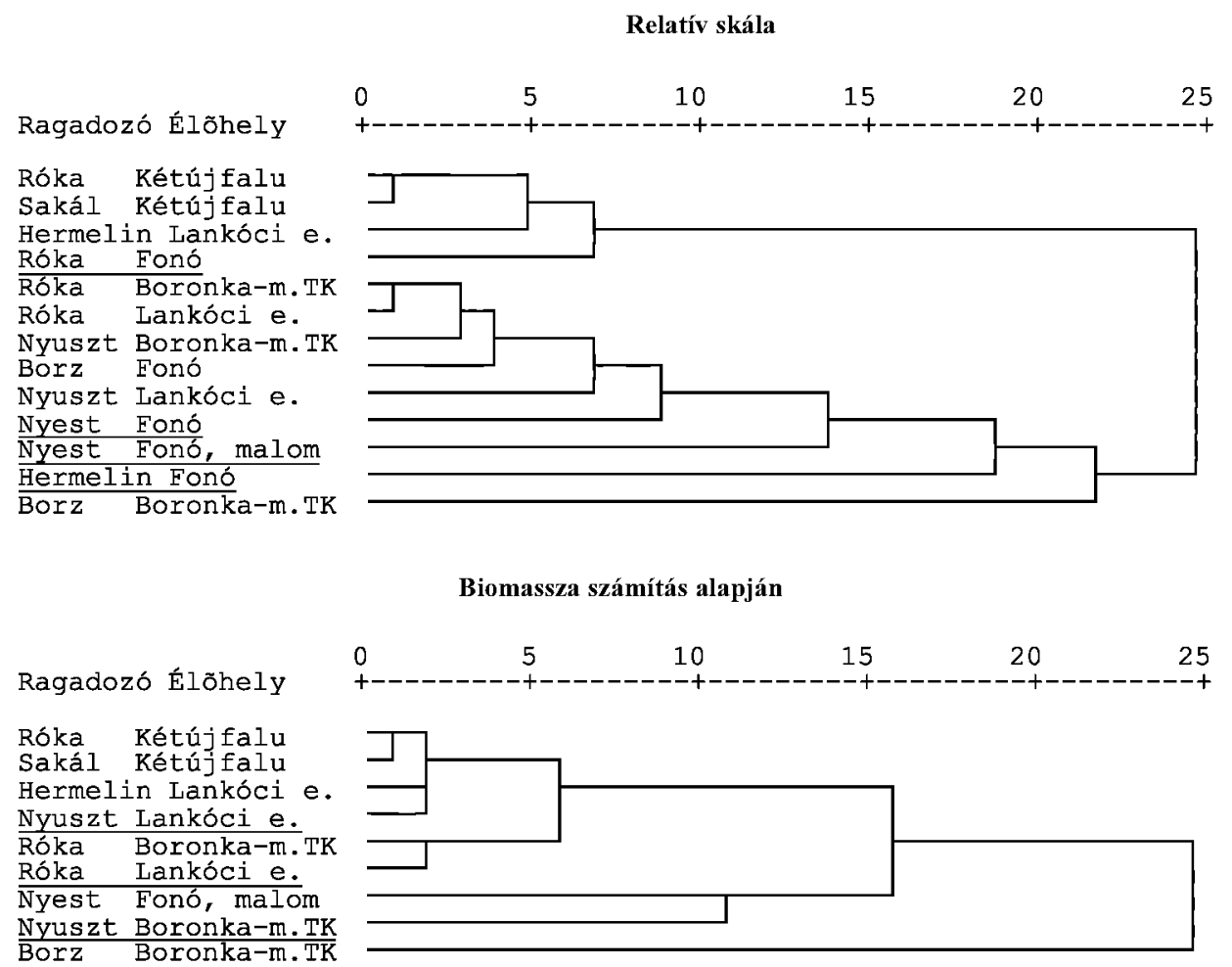

81. ábra: Szárazföldi ragadozók táplálék-összetételének hasonlósága nyári-öszi időszakban

\section{Szárazföldi ragadozó fajok közötti táplálkozási versengés}

Ebben az alfejezetben elsősorban a vizsgált ragadozó életközösségeken belül tapasztalt aktuális táplálkozási niche-átfedés számítások szerepelnek. Azonban a potenciális táplálkozási átfedés mértékének ismerete is érdekes információ lehet az interspecifikus kapcsolatok, a kompetíció és a niche-szegregáció jelenségének magyarázatához. Ezért kivételes esetekben, a vizsgált területeken tényleges életközösséget nem alkotó fajok közötti lehetséges kapcsolatokat is megemlítem. Ezt az indokolja, hogy egyes fajok (pl. farkas, sakál) régión belüli elterjedése akár néhány éven belül is változhat.

A vizsgált legkisebb testméretủ ragadozó, a hermelin tápláléka élőhelytơl függốn jelentôs mértékü niche-átfedést mutatott a közepes testméretű ragadozókkal A Fonói tó körzetében a nyesttel és a rókával közepes (57-63\%), a borzzal téli-tavaszi időszakban alacsony (11\%), nyáron és ósszel közepes (60\%) átfedést lehetett tapasztalni. A Lankócierdőben élő hermelin és nyuszt, illetve róka esetén időszaktól és számítási módtól függetlenül közepesen nagy volt a táplálék átfedés (51-79\%).

A Fonói tó körzetében élő nyest, valamint a vele életközösséget alkotó róka közötti niche-átfedés időszaktól függetlenül közepesen magas (68-70\%), a borzzal a téli-tavaszi időszakban közepesen alacsony (39\%), nyári-ôszi időszakban nagymértékü (72\%) volt. Az urbánus és a mezőgazdasági környezetben élő nyestek közötti niche-átfedés 78\%-ot tett ki. 
Az erdőlakó nyuszt és a róka közötti niche-átfedés területtől függetlenül, különösen biomassza számítás alapján volt nagymértékü (78-84\%). A nyuszt és a borz között előfordulási gyakoriság számítás alapján közepesen alacsony (42-47\%), biomassza számítás alapján alacsony (11-28\%), továbbá a hermelinnel számításmódtól függetlenül nagymértékü (62-79\%) átfedést lehetett tapasztalni.

Az aranysakál és a róka közötti niche-átfedés a sakál hazai elterjedésének központjában (Kétújfalu körzetében) téli-tavaszi időszakban közepesen magas (70-76\%) és nyáriőszi időszakban igen magas volt (91-95\%). A sakál hazai elterjedésének peremén (MikeCsököly körzetében) élő sakál és róka között, téli-tavaszi időszakban, az előzőekben leírtakhoz hasonló, közepesen magas (60-72\%) átfedés volt tapasztalható.

A ragadozó emlős életközösségben együtt élő (koegzisztens) fajok között, a táplálékforrások közös használata jelentős mértékú, amit az esetek többségében tapasztalt közepes, vagy közepesen nagy táplálkozási niche-átfedés jelez. Kivétel a borz, mely a többi fajjal közepesen alacsony átfedést mutatott.

A továbbiakban a potenciális átfedéseket értékelem.

Érdekes eredményt adott a sakál hazai elterjedési peremén és központjában élö populációk téli-tavaszi tápláléka közötti niche-átfedés vizsgálata, ugyanis az átfedés mindössze közepes volt (60-62\%).

A farkas és a hiúz az aranysakállal tényleges életközösséget nem alkot, potenciálisan azonban együtt is elófordulhatnának. A három faj areája, hozzánk meglehetősen közel: a Balkán-félszigeten átfedi egymást (TRENSE 1989, Mitchell-Jones et al. 1999), bár MiTCHELL-JONES et al. (1999) szerint, ahol farkas él, ott sakál nem fordul elö. A nálunk eddig szinte ismeretlen aranysakál ökológiai szerepének vizsgálata érdekében végeztem összehasonlítást a kisebb és a nagyobb testű ragadozókkal egyaránt. A téli-tavaszi időszakra vonatkozó eredmények azt mutatják, hogy a hazai elterjedésének központi területen élő aranysakál és az Északi-középhegységben élő farkas, valamint a hiúz közötti niche-átfedés előfordulási gyakoriság számítás alapján alacsony (27-32\%), biomassza számítás alapján pedig rendkívül kismértékü (4-7\%) volt. A Kétújfalu körzetében élő vörösróka valamint a nagyragadozók között, a sakáléhoz hasonló közepes, illetve kismértékủ táplálékbeli átfedés volt tapasztalható. Az aranysakál hazai elterjedésének peremén élő sakál és róka, valamint az Északi-középhegységben élő farkas között a számításmódtól függetlenül közepes (44-51\%), valamint a hiúzzal relatív gyakoriság számítás alapján szintén közepes (41-46\%), biomassza számítás alapján alacsony (9-24\%) nicheátfedés volt tapasztalható.

A niche-átfedés témakörben kapott eredmények összhangban állnak a cluster-analízissel kapott fó tendenciákkal.

\section{A táplálékforrások felosztásának lehetőségei}

Az életközösséget alkotó fajok egyedeinek tartós együttélése térbeli és időbeli elkülönülés révén valósulhat meg, melyet nemcsak a táplálkozási kapcsolatok, hanem számos egyéb tényező is befolyásol. A niche-szegregációt ezúttal csak a táplálkozás oldaláról vizsgáltam két lényeges szempont: a fogyasztott préda súlya és jellemzó élóhelye szerint. A prédaválasztásra vonatkozó adatok fajonként az egyes fejezetekben megtalálhatók, itt a fajok (és élöhelyek) összehasonlító vizsgálatának eredményét ismertetem. 


\section{A prédaválasztás összehasonlító vizsgálata a zsákmány súlya alapján}

A 82. ábra szemlélteti az egyes ragadozó fajok prédaválasztásában mutatkozó hasonlóságot. A csoportosítás alulról felfelé haladva követhető. Az első csoportba a nagy (300 g feletti) súlyú prédán éló, nagytestú ragadozók: a hiúz és a farkas tartoztak, melyek lényegesen elkülönültek a többi fajtól. Hasonlóképp külön csoportot alkotott a zömmel apró, $15 \mathrm{~g}$ alatti prédát (gilisztát, bogarakat) fogyasztó borz is. A harmadik csoportban olyan fajok és területek szerepeltek, ahol idószakonként számottevő volt a nagyobb súlyú préda fogyasztása. Ebbe a csoportba sorolható a Mike-Csököly körzetében élö sakál és róka, a Petesmalom körüli erdókben, valamint a Fonói tó körzetében élő róka. A negyedik csoportba olyan fajok (és területek) tartoztak, melyeknél a 15 és 50 g közötti súlykategóriába sorolt préda dominált. Ilyenek a hermelin (élőhelytől függetlenül), valamint a Kétújfalu körzetében élő aranysakál és vörösróka. Az ötödik csoportba a két vizsgált erdei élőhelyen élő nyuszt és róka, valamint a mezőgazdasági területen élő nyest sorolható. Ezek táplálékában leggyakrabban 15-50 g súlyú préda fordult elö, de ennél kisebb és nagyobb zsákmányt is viszonylag gyakran fogyasztottak. Az urbánus nyest kissé elkülönült a két utóbbi csoporttól.

\section{A prédaválasztás összehasonlító vizsgálata a zsákmány jellemzó élóhelye alapján}

A ragadozó fajok prédaválasztásának hasonlóságát a fogyasztott zsákmány jellemzó élőhelye (szintje) alapján a 83. ábra szemlélteti. A préda élőhelye szerinti forrásfelosztásban, szintén jól elhatárolható csoportok találhatók. Az első csoportba az urbánus nyest, valamint a Fonói tó körzetében élő hermelin sorolható, melyek táplálékának nagyobb részét ugyan talajszinten élő fajok teszik ki, de jelentős a bokrokon, fákon élố préda zsákmányolása is. A második csoportba sorolt erdőlakó nyuszt és hermelin, valamint a mezőgazdasági környezetben élő nyest és a Mike-Csököly körzetében élő róka táplá-

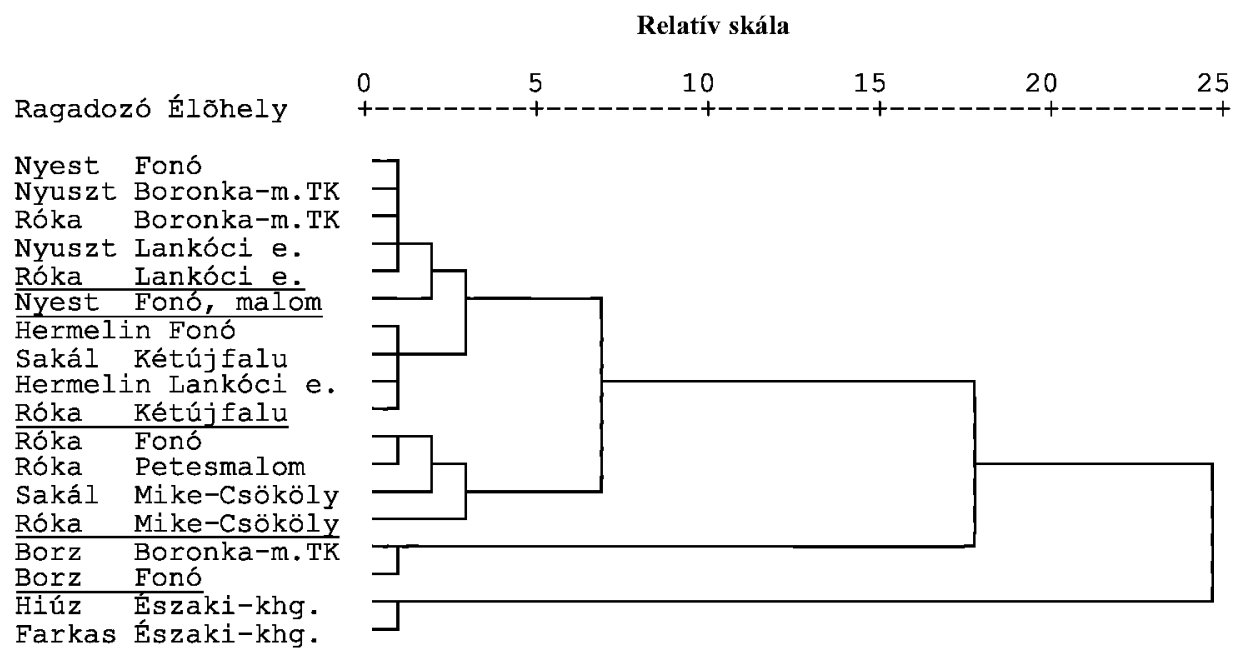

82. ábra: A prédaválasztás hasonlósága a zsákmány súlya alapján 
lékában zömmel talajlakó préda szerepelt, de előfordult benne bokrokon, fákon található, valamint ritkán vizes élöhelyhez kötődő zsákmány is. A harmadik csoportba sorolt borz (Boronka-melléki TK), valamint a Petesmalmi halastavak körzetében éló róka táplálékában a legfontosabb terresztris fajok mellett a vizes élőhelyhez kötődő préda fogyasztása is jelentős volt. A negyedik csoportba sorolt ragadozók táplálékában alapvetően talajszinten lakó fajok szerepeltek, a többi prédatípus jelentősége minimális. Ide tartozik a Fonói tó körzetében élő borz, az aranysakál, a vizsgált rókák többsége, valamint a hiúz és a farkas is.

A vizsgálatokból látható, hogy a különbözô ragadozó fajok a rendelkezésre álló táplálék-forrásokat eltérő mértékben hasznosítják a préda súlyától és jellemzố élöhelyétől függően. A prédaválasztást azonban az élőhely jellege is befolyásolja. Ennek megfelelően lényegesen eltérő csoportban szerepelhet ugyanaz a predátor faj, ha erdei, vagy mezőgazdasági területen él. Erre a legjobb példa a vörösróka.

Összességében megállapítható, hogy a vizes élőhelyekhez kötődő vidra táplálékspektruma széles. Ez is hozzájárul ahhoz, hogy zsákmányszerzésében képes alkalmazkodni a rendelkezésre álló táplálék-készlethez vagyis az élőhely jellegétől függóen többféle táplálék-forrást is hasznosít. A különbözó típusú élőhelyeken, a táplálkozási niche-szélessége változatos képet mutat. Bőséges haltáplálék-készlet mellett niche-e szúk, ugyanis legfontosabb táplálékát a hazai ökológiai feltételek mellett a hal jelenti. Ilyen esetek leginkább a horgászati-, vagy halászati hasznosítás alatt álló területeken voltak tapasztalhatók. Alacsony halkészlet mellett, és jelentős emberi zavarás esetén a vidra előfordulása bizonytalanná válik. A kapott adatok világosan jelzik, hogy a vidra a vizes élőhelyek állapotának változására érzékenyen reagáló faj. Részletes külföldi és hazai kutatottsága ellenére mégis a száz éves dogmák mocsarába veszni látszik a rövid távú gazdasági érdekek miatt. Védelmi státuszának megváltoztatása a hazai állományok alaposabb megismeréséig (genetikai analízisre alapozott populáció dinamikai valamint ökotoxikológiai vizsgálatok végzéséig) semmiképp nem indokolt.

A fơként kisemlősökkel, esetenként kistestủ madarakkal táplálkozó hermelin táplálékösszetétele taxonómiailag nagy hasonlóságot mutat a vele életközösséget alkotó róká-

Relatív skála

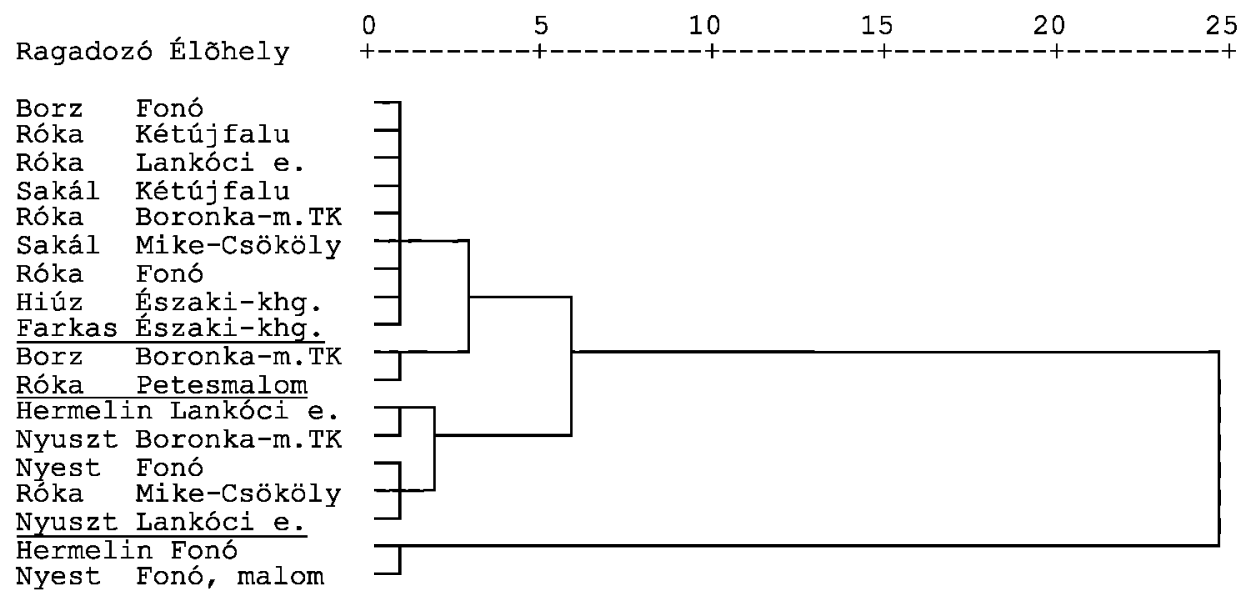

83. ábra: A prédaválasztás hasonlósága a zsákmány preferált élőhelye alapján 
hoz, valamint a préda súlya és jellemző élőhelye szempontjából a nyesthez és a nyuszthoz is. Táplálkozási niche-e széles, ami azt jelzi, hogy képes alkalmazkodni a különböző típusú élöhelyek feltételeihez, de a faj érzékenységét jelzi, hogy tápláléka a vizsgált fajok között a leginkább egyhangú.

A lakott területen éló nyest táplálék-összetétele alapján elkülönül a többi ragadozó emlőstől. Ebben az ember környezetében megtalálható táplálékforrások (háziállatok, rágcsálók, gyümölcsök, hulladék) kihasználása játszik közre. A mezőgazdasági környezetben élő nyest tápláléka a többi kis- és közepes testméretű ragadozó faj táplálékához nagy hasonlóságot mutat. Kiváló alkalmazkodó képessége és széles elterjedése miatt a nyest nem tartozik a veszélyeztetett fajok közé.

Az erdőlakó nyuszt táplálékában minden évszakban a kisemlősök dominálnak, a madárfogyasztás csak nyáron számottevő, de ekkor is csak másodlagosan fontos. Tápláléka nagyban hasonlít a vele életközösséget alkotó, szintén sokféle táplálékot fogyasztó rókáéhoz. A nyuszt természetvédelmi megítélésekor tehát figyelembe kell(ene) venni, hogy az erdők madárállománya valóban a nyuszt jelenlétének köszönhetően csökken-e, vagy abban más, fontosabb tényezók (pl. erdógazdálkodás) játszanak közre. Az eredmények magukért beszélnek.

A borz határozottan elkülönül a többi szárazföldi ragadozótól táplálkozási szempontból. Tekintve, hogy gilisztával és kétéltúekkel táplálkozik, préda fajai igen kis súlyúak. Táplálkozási niche-e a vizsgált fajok között a legkeskenyebbek közé tartozik. E szerint táplálék specializáció jellemző rá. Azonban a különbözó élőhelyeken más-más táplálékforrásokat képes hasznosítani, ami viszont azt jelzi, hogy a borz táplálkozásában jó alkalmazkodóképességgel rendelkezik. A faj természetvédelmi és gazdasági megítélése tehát nem lehet általános (egységes) az ország különbözó területein. Állományváltozását folyamatosan nyomon kell követni és szükség esetén (akár régiónként) vadászatát fel is lehet függeszteni.

A róka és a vizsgált kis- és közepes testméretü szárazföldi predátor fajok között jelentős versengés tapasztalható a táplálék-források hasznosításáért.

A sakál és a róka közötti táplálkozási kapcsolat lényeges szempont a sakál ökológiai szerepének értékelésekor. Az eredmények azt mutatják, hogy élőhelytől és időszaktól függetlenül kiemelkedően nagymértékü hasonlóság tapasztalható a sakál és a róka táplálék-összetétele és táplálkozási szokásai között. Ugyanakkor különbség tapasztalható a sakál hazai elterjedésének peremén és központjában élő sakálok között (hasonlóképp a két terület rókái között is). Ez azt jelzi, hogy az élöhelyi adottságok nagyban megszabják ezen predátorok táplálkozási szokásait. Mindkét faj jól tud alkalmazkodni az élöhely adta lehetőségekhez, miközben jelentős arányú dögfogyasztás, vagy szélsôséges kisemlös fogyasztás is előfordulhat. A sakál tápláléka lényegesen eltér a nagyragadozókétól, testmérete és vadászati stratégiája a farkas és a vörösróka között áll, de inkább a rókához közelít. A táplálék-összetétel, a préda mérete és élőhelye, a táplálkozási niche-szélesség és a niche-átfedés elózetes vizsgálata alapján megállapítható, hogy a Magyarország déli területeire visszatelepült, közepes testméretúl aranysakál táplálkozási szempontból hasonló ökológiai niche-t tölt be, mint a vörösróka. 


\section{Összefoglalás}

A tanulmányban 1991 és 2001 között vizsgált hét ragadozó emlős faj szerepel, ezek: a vidra (Lutra lutra), a hermelin (Mustela erminea), a nyest (Martes foina), a nyuszt (Martes martes), a borz (Meles meles), a vörösróka (Vulpes vulpes) és az aranysakál (Canis aureus). A vizsgált területek dél-nyugat Magyarországon helyezkednek el, részben mezögazdasági müvelés alatt állnak (Fonói tó, Kétújfalu és Mike-Csököly körzete), részben erdő́k (Gyékényesen a Lankóci erdő), vagy erdőkkel övezett tavak (Boronkamelléki Tájvédelmi Körzet és Petesmalom). Ezeken kívül a Duna-Dráva Nemzeti Park vizes élőhelyein vizsgáltam a vidra táplálkozási szokásait, így a Dráván (ÖrtilosSzentmihályhegyen és Vízváron), holtágakon (Bélaváron, Babócsán és Barcson, a Kisbókon), tavakon (Somogyudvarhelyi kavicsbánya tavakon és Barcson, a Rigóc patak tavain), valamint csatornákon és patakokon (a Dombó csatornán, a Babócsai Rinyán, a Barcs-Komlósdi Rinyán és a Korcsinán). A ragadozó emlősök táplálék-összetételének vizsgálata hullaték analízissel történt, összességében több mint tízezer minta alapián.

Eutróf halastavakon (a Fonói tavon és a Boronka-melléki Tájvédelmi Körzetben) vizsgáltam a vidra táplálkozási szokásait és halpreferenciáját. A vidra haltápláléka és a rendelkezésre álló haltáplálék-készlet relatív gyakorisági adataiból számolt korrelációs együtthatók $\left(\mathrm{r}_{\mathrm{P}}\right)$ általában szorosak voltak, így a Fonói tavon 6 év alatt: $0,56(\mathrm{P}<0,05)$, 0,87 ( $\mathrm{P}<0,001), 0,93(\mathrm{P}<0,001), 0,79(\mathrm{P}<0,05), 0,36(\mathrm{NS})$ és 0,81 ( $\mathrm{P}<0,001)$, a Boronkamelléki Tájvédelmi Körzetben két év alatt: 0,02 (NS), 0,33 (NS). Az esetenként tapasztalt alacsony korrelációs értékek azt jelezték, hogy a vidra haltáplálék választását nemcsak a halak faja határozta meg, hanem jelentős volt a halak méret szerinti preferenciája is $\left(\mathbf{r}_{\mathrm{S}}=0,70, \mathbf{P}<0,01\right)$. A halpreferencia-számítás Ivlev-féle preferencia index alkalmazásával történt $\left(\mathrm{E}_{\mathrm{j}}\right.$, min.:-1, max.: +1$)$. A vidra a nagy súlyú, $1000 \mathrm{~g}$ feletti halakat fajtól függetlenül, az elöfordulási gyakoriságuknál kisebb arányban fogyasztotta $\left(\mathrm{E}_{\mathrm{i}}=-0,51\right)$, az 500 és $1000 \mathrm{~g}$ közötti halakat preferálta $\left(\mathrm{E}_{\mathrm{i}}=0,79\right)$. Nem volt jelentö́s és határozott preferencia az $500 \mathrm{~g}$ alatti mérettartományra $\left(\mathrm{E}_{\mathrm{i}}=-0,02-0,38\right)$.

A halak víztérben való jellemző elöfordulási régiója szerinti preferencia is jelentős volt $(\mathbf{P}<0,01)$. A vidra, az elófordulási gyakoriságuknál kisebb arányban fogyasztotta az elsősorban nyíltvízi $\left(E_{\mathrm{i}}=-0,64\right)$ és a vízfenék közelben élő halakat $\left(E_{\mathrm{i}}=-0,22\right)$. Elönyben részesítette a vízinövényekkel (hínár fajokkal) benőtt területen $\left(\mathrm{E}_{\mathrm{i}}=0,46\right)$ és kismértékben a sekély part menti régiókban élő halakat $\left(\mathrm{E}_{\mathrm{i}}=0,14\right)$. A halgazdálkodás elmaradásával és a növényzetben bekövetkezett drasztikus változások hatására a vidra a rendelkezésre álló, vízhez kötődő, de egyébként másodlagos táplálék-készletet (kétéltủek és vízi rovarok) jelentős mértékben hasznosította, eközben évszaktól függően, esetenként akár másodlagos fontosságú táplálékká váltak a halak.

Egyes Dráva-menti vizes élőhelyeken, így a Dráva folyón, a Barcsi Borókás Tájvédelmi Körzet tavain, a kavicsbánya tavakon, a Bélavári-, a Kisbóki- és a Babócsai holtágon a vidra fő táplálékát bőséges haltáplálék-készlet esetén halak alkották. A táplálékban a halak időszakonkénti alacsony (kb. 50-60\% alatti) elöfordulási gyakorisága azt jelezte, hogy a haltáplálék-forrás nem állt rendelkezésre megfelelő mennyiségben, vagy az évszakok között nagymértékben ingadozott. Ezeken a területeken a másodlagos táplálék- 
források (madarak, kétéltűek és hüllők) szerepe jelentős volt. A nyári időszakban részlegesen kiszáradó élőhelyeken, pl, a Lankóci-erdőben, egyes csatornákon és patakokon a kisemlősök és vízirovarok fogyasztása is fontossá vált, miközben a halak alárendelt szerepet játszottak a táplálkozásban. A különleges esetnek számító Tetves patakon élő vidra táplálékában nyáron a tízlábú rákok fogyasztása kiugróan nagy volt (mennyiségi arány $62 \%$ ). A tavakon élố vidrák niche-e, a nagyobb arányú halfogyasztás miatt szúkebb volt, mint a Dráva-menti vizes élöhelyeken.

A Petesmalmi tavakon, a Lankóci-erdőben és a Tetves patakon gyújtött minták alapján vizsgáltam a vidra táplálékában a relatív előfordulási gyakoriság és a biomassza adatok közötti összefüggést. A taxononkénti adatok közötti Pearson korrelációs összefüggés az emlősöknél $\mathrm{r}=0,92$, ( $\mathrm{P}<0,01)$, a madaraknál $\mathrm{r}=0,80(\mathrm{P}<0,05)$, a hüllöknél és kétéltúeknél $\mathrm{r}=0,93(\mathrm{P}<0,001)$, a halaknál $\mathrm{r}=0,90(\mathrm{P}<0,001)$, a gerincteleneknél $\mathrm{r}=0,88$ $(\mathrm{P}<0,001)$ és a növényeknél $\mathrm{r}=-0,78(\mathrm{P}=0,066)$ volt. Az adatok azt jelzik, hogy a préda taxonok előfordulási gyakorisági adatai a táplálék mennyiségi viszonyait nagy megbízhatósággal reprezentálták.

A hermelin legfontosabb táplálékát a kisemlősök, ezen belül is a pocokfélék alkották. A kisemlősök aránya télen volt a legnagyobb, majd a nyári-őszi időszakig fokozatosan csökkent. Ezzel együtt a madarak, valamint a rovarok szerepe nótt a táplálkozásban, de előfordult hüllők és növények fogyasztása is. A lényegesen eltérő élőhelyeken, így a Fonói tó körzetében és a Lankóci-erdöben vizsgált hermelin táplálékának egyhangúsága ellenére a fó taxonok alapján táplálkozási niche-e széles volt. A préda taxonok száma 18 , illetve 11 , a növény taxonok száma 4 , illetve 1 volt a fenti két élőhelyen. A hermelin zsákmányának többségét 15 és $50 \mathrm{~g}$ közötti súlyú fajok alkották. A préda fajok döntő többsége talajszinten élt, de jelentősek voltak a cserjék szintjén élők, valamint a táplálékában előfordultak vizes élőhelyhez kötődő fajok is. A hermelin táplálék-összetétele taxonómiailag nagy hasonlóságot mutatott a vele életközösséget alkotó rókához, valamint a préda súlya és jellemzó élőhelye szempontjából a nyesthez és a nyuszthoz is.

A nyest táplálékát mezógazdasági és urbánus környezetben, a Fonói tó körzetében és Fonó község belterületén vizsgáltam. A különböző élőhelyeken élő egyedek gyakran közös táplálékforrást hasznosítottak, táplálkozási niche-átfedésük 78\% volt. Mindkét területen jellemző volt, hogy táplálékukban a növények, főleg gyümölcsök domináltak (éves átlagban 34, illetve $31 \%$, relatív gyakoriság adatok alapján). Ezek mellett a mezögazdasági környezetben élő nyestnél a kisemlősök $(20 \%)$, az urbánus egyedeknél a madarak voltak a legjelentősebb préda fajok (20\%). A háziállatok (főként baromfifélék) fogyasztásában lényegesen különbség (4, illetve 15\%) volt tapasztalható. A táplálkozási niche szegregálódásban közrejátszott, hogy a mezőgazdasági környezetben élő nyest gyakrabban fogyasztott kisebb súlyú és talajszinten élö, valamint jellemzően vadon élő prédát, ellentétben az urbánus nyesttel. A mezőgazdasági környezetben élö nyest tápláléka a többi kis- és közepes testméretủ ragadozó faj táplálékához nagy hasonlóságot mutatott. A préda taxonok száma 55, illetve 35, a növény taxonok száma 17 , illetve 19 volt a két területen.

A nyuszt legfontosabb táplálékát a Boronka-melléki Tájvédelmi Körzetben és a Lankóci-erdóben egyaránt a kisemlősök alkották, arányuk különösen téli és tavaszi időszakban volt nagy. A legfontosabb táplálék faj az erdei pocok volt, emellett az erdeiegér fajok fordultak eló nagy gyakorisággal. A Boronka-melléki Tájvédelmi Körzetben a nyuszt az erdei pockot $\left(E_{i}=0,10\right)$ és a peleféléket $\left(E_{i}=0,16\right)$ kismértékben elónyben részesítette zsákmányszerzése során, az erdei egereket $\left(\mathrm{E}_{\mathrm{i}}=-0,14\right)$, valamint a cickányféléket $\left(E_{i}=-0,28\right)$ pedig az előfordulási gyakoriságuknál kisebb mértékben zsákmányol- 
ta. Az évszakonkénti táplálékválasztást a kisemlős táplálék-készlet összetétele befolyásolta. A nyuszt táplálékában a madarak másodlagosan fontos szerepet töltöttek be, föként a nyári és az őszi időszakban. A madártáplálékot zömmel kistestú énekesmadarak alkották. A táplálékként gyakran előforduló gerincteleneket kis mennyiségben fogyasztotta. A többi táplálék taxon fontossága élöhelytốl függóen lényegesen különbözött. Például téli időszakban jelentós mennyiségben táplálkozott elhullott nagyvadakból, a halastavak közelében pedig halakból. A növények szerepe évszaktól és élőhelytől fuuggően eltért, nyári időszakban akár a nyuszt legfontosabb táplálékát is alkothatták a különbözố vadon termő gyümölcsök, és szerepük ósszel is jelentős volt. A nyuszt fajokban gazdag tápláléka minden évszakban széles táplálkozási niche-sel járt együtt. A préda taxonok száma 62 , illetve 49 , a növény taxonok száma 11 , illetve 8 volt a vizsgált két élőhelyen. A zsákmányának döntő hányadát apró, $50 \mathrm{~g}$ alatti állatok alkották. Annak ellenére, hogy kiváló famászó, a préda fajainak zöme talajszinten élt, viszonylag ritkán zsákmányolt kifejezetten fákon és bokrokon élő fajokat. Az erdőlakó nyuszt tápláléka nagyban hasonlított a vele életközösséget alkotó szintén sokféle táplálékot fogyasztó rókáéhoz.

A borz táplálék-összetétele az erdőkkel övezett halastavak körzetében, így a Boronkamelléki Tájvédelmi Körzetben, valamint mezőgazdasági területen, így a Fonói tó körzetében lényegesen eltért. Az erdei területen élő borz téli táplálékában a gerinctelenek (elsősorban a földigiliszta), tavasztól őszig pedig a hüllők és a kétéltủek voltak a legjelentősebbek. A kisemlösök és a többi zsákmány taxon szerepe nem volt meghatározó. Mezőgazdasági területen a borz nyári és őszi táplálékában a gerinctelenek (főként a földigiliszta), ősszel a növények (fóként a kukorica) és a kisemlősök (különösen a mezei pocok) szerepe volt jelentős. Mindkét területen a fajokban gazdag táplálék mellett közepes, vagy alacsony niche-szélesség volt tapasztalható. A préda taxonok száma 47, ill. 25, a növény taxonok száma 11, ill. 6 volt a vizsgált két élőhelyen. A táplálékban - a gerinctelenek gyakori elófordulása miatt - a kis súlyú, 15 g alatti, talajszinten éló préda dominált. Táplálkozási szokásai alapján, a borz határozottan különbözött a többi szárazföldi ragadozótól. Táplálkozási niche-e, a vizsgált fajok között a legkeskenyebbek közé tartozott, vagyis adott élőhelyen táplálék specialista. Alkalmazkodóképességet mutatja, hogy a különböző élőhelyeken más-más táplálékforrásokat hasznosított.

A vörösróka tápláléka fajokban gazdag, táplálkozási niche-e általában széles volt, ami táplálkozási szempontból kiváló alkalmazkodóképességet jelzett. A mezőgazdasági területen (a Fonói tó körzetében és Kétújfalu körzetében) élő rókák táplálékában 40-42 zsákmány és 10-12 növény taxon fordult elő. Az erdei környezetben élő rókák tápláléklistáján ezeknél általában több taxon szerepelt, így a Boronka-melléki tájvédelmi Körzetben 66 zsákmány és 15 növény, a Lankóci-erdőben pedig 47 zsákmány és 8 növény taxon. Legfontosabb táplálékát a terület jellegétől és évszaktól függően (biomassza számítás szerint 46-94\%-ot) kisemlősök alkották. Prédáinak zöme a 15 és 50 g közötti súlytartományba tartozott. A mezőgazdasági területeken a gazdasági kárt okozó mezei pocok, az erdei élóhelyeken pedig általában az erdei pocok volt a legfontosabb zsákmány faj. A Boronka-melléki Tájvédelmi Körzetben a róka az erdei pockot $\left(E_{i}=0,11\right)$ kismértékben előnyben részesítette zsákmányszerzése során, az erdei egereket $\left(E_{i}=-0,14\right)$ pedig az előfordulási gyakoriságuknál kisebb mértékben zsákmányolta. A vörösróka, valamint a többi kis-és közepes testméretű szárazföldi predátor között nagymértékủ táplálkozási niche-átfedés volt tapasztalható.

Az aranysakál az elmúlt évtizedben települt vissza dél-nyugat Magyarországra. A hazai elterjedés peremterületén élő egyedek téli-koratavaszi táplálékában kisemlősök voltak az elsődlegesen fontosak (mennyiségük aránya 56\%). Emellett a táplálkozásban je- 
lentős szerepet töltöttek be az elhullott nagyvadak is (gímszarvas, dámvad, őz, vaddisznó, mennyiségük aránya összesen $41 \%$ ). Az egyéb táplálék taxonok, így a madarak, a hüllők, a kétéltủek, az ízeltlábúk és a növények nem játszottak fontos szerepet a táplálkozásban; hal és háziállat nem fordult elő táplálékként. Az apróvad (mezeinyúl és fácán) predációja nem volt jelentős. A területen élố vörösróka táplálékában a kisemlösök részaránya $36 \%$, az elhullott állatoké $49 \%$ volt (biomassza számítással). A sakál és a róka táplálék-összetétele nem tért el jelentősen, a niche-átfedése különösen a biomassza adatok alapján volt nagymértékü $(72 \%)$. Az aranysakál hazai elterjedésének központjában élő egyedek táplálékában a kisemlösök elsődlegesen fontosak voltak (évszaktól függően mennyiségük aránya 83-97\%), a fö táplálék a mezei pocok volt. Kisemlősök ôszi elevenfogó csapdázása alapján a sakál előnyben részesítette a mezei pockot $\left(\mathrm{E}_{\mathrm{i}}=0,33\right)$, továbbá előfordulási gyakoriságuknál kisebb arányban fogyasztotta az erdei pockot és az erdeiegér fajokat $\left(\mathrm{E}_{\mathrm{i}}=-0,59,-0,77\right)$. A csülkös vadak fogyasztása tavasz végén, nyáron emelkedett meg, azonban ekkor is csak másodlagosan fontos táplálékot jelentettek. A sakál niche-szélessége a kiemelkedően nagyarányú kisemlős fogyasztás miatt, évszaktól függetlenül alacsony volt, mely alapján a vizsgált élőhelyen kisemlős-specialista életmód volt jellemző rá. A területen élő vörösróka táplálékában szintén a kisemlősök domináltak (mennyiségük aránya 80-94\%). A sakál és a vele életközösségben előforduló róka tápláléka nem tért el lényegesen, a niche-átfedés jelentős volt, évszaktól függően 76 és $95 \%$ között alakult.

Élőhelytơl és időszaktól függetlenül kiemelkedően nagymértékű hasonlóság tapasztalható a sakál és a róka táplálék-összetétele és táplálkozási szokásai között. Ugyanakkor különbség tapasztalható a sakál hazai elterjedésének peremén és központjában élő sakálok között (hasonlóképp a két terület rókái között is). Ez azt jelzi, hogy az élóhelyi adottságok nagyban megszabják ezen predátorok táplálkozási szokásait. Mindkét faj jól tud alkalmazkodni az élöhely adta lehetőségekhez, miközben, jelentős arányú dögfogyasztás, vagy szélsőséges kisemlós fogyasztás is előfordulhat. A lakott területeket elkerülö sakál tápláléka lényegesen eltér a nagyragadozókétól, testmérete és vadászati stratégiája a farkas és a vörösróka között áll, de a rókához közelebb. A táplálék-összetétel, a préda mérete és élőhelye, a niche-szélesség és a niche-átfedés vizsgálat alapján megállapítható, hogy a Magyarország déli területeire visszatelepült, közepes testméretű aranysakál hasonló ökológiai niche-t tölt be táplálkozási szempontból, mint a vörösróka. 


\section{Zárógondolatok és köszönetnyilvánítás}

Néhány megjegyzést engedjen meg a Tisztelt Olvasó.

Napjainkig akár könyvtárakat megtöltő, széleskörü nemzetközi tudományos és ismeretterjesztő irodalom áll rendelkezésünkre a különböző ragadozókról, és az oktatási intézményekben is általában korszerủ ismereteket tanítanak. Magyarországon, vagyis a velünk élố ragadozó emlősök alaposabb megismerése iránti igény terén mégis meglehetôsen nagy lemaradás tapasztalható. A külföldi eredményeket ugyanis ésszerűtlen lenne változatlanul, a hazai környezeti feltételek mellett adaptálni. Másrészt a kevéssé ismert hazai fajok is lehetnek valamilyen szempontból különlegesek, jelentósek és kutatásra inspirálók.

A ragadozók táplálék-konkurensei az embernek, és sokszor a szenzációhajhászó, tudománytalan (ál)hírekkel is csak szítják a gazdálkodói és természetvédelmi ellentéteket. Sajnos még mindig idejétmúlt hiedelmek és megkövült szokások élnek velük szemben. Sok tekintetben ma sem jobb a helyzet, mint évtizedekkel-évszázadokkal ezelött volt. Ưgy tűnik, mintha megállt volna az idő, amikor ragadozókról esik szó. Megszívelendők a természetet rajongásig szerető és értő, számomra mindig a legkedvesebb író, Fekete István sorai, melyeket a Rózsakunyhó címü könyvében, a vadászati kultúráért szóló fejezetben írta a ragadozóról, amiből könyvem elején idéztem is.

A törvények önmagukban nem képesek megvédeni az állatokat és élöhelyeiket sem. A szemléletváltáshoz nagyon fontos a fajok, valamint az életközösségek müködését szabályozó törvényszerüségek pontosabb megismerése. Ez végül belátáshoz és a fajok megkíméléséhez, ésszerū hasznosításához, végső soron a fajgazdagság hosszú távú megőrzéséhez vezet. Addig igyekezzünk ezt megtenni, amíg van mit megkímélni, amíg színes az élővilágunk. A kultúrsivatagokban ugyanis nem túl sok jó terem. A világ iparilag és mezőgazdaságilag fejlettebb számos régiójából tűntek el fajok, vagy ritkult meg drasztikusan az állományuk. A visszatelepítés, az élőhelyek rehabilitációja pedig roppant összegeket emészt fel.

A kötetben szerepló kutatás a fajok táplálkozásának alaposabb megismerésére irányult, a könyv célja pedig az eredmények mértéktartó és lehetóleg elfogultság nélküli bemutatatása volt, nem pedig a valóságtól kedvezőbb, vagy rosszabb színben való feltüntetése. Tettem ezt annak reményében, hogy táplálkozásuk oldaláról kicsit jobban megismerve, talán többen is megkedvelik ezeket a csodálatosan szép és különleges állatokat. A predáció szempontjából pedig, hogy mi "sok", vagy "kevés"? - végsố soron a vadgazdálkodási, a halászati és a természetvédelmi gyakorlatban dől majd el. A vizsgálatok nem tekinthetők lezártnak, de bízom abban, hogy már ezek az ismeretek is hozzájárulhatnak a ragadozó emlös fajaink megórzéséhez.

Köszönetet mondok az elmúlt években a kutatómunkában közremúködő kollégáimnak, barátaimnak, akik tanácsaikkal és észrevételeikkel segítettek. Közülük is külön hálával tartozom: Bognár Zoltánnak, Dormán Zoltánnak, Gellai Tibornak, Gera Pálnak, Hancz Csabának, Hivatal Nándornak, Horváth Győzőnek, Kolozsi Gézának, Nádorfalvy Józsefnek, Nagy Tibornak, Pécsi Istvánnak, Pintér Andrásnak, Purger Jenőnek, Romvári 
Róbertnek, Sugár Lászlónak, Szemethy Lászlónak, Tömösváry Tibornak, Szendrő Zsoltnak és Váradi Györgynek. Külön köszönöm Deborah L. Moss-nak az angol nyelvú kéziratok készítésénél nyújtott nélkülözhetetlen segítségét. Köszönöm továbbá a Somogy Természetvédelmi Szervezetnek, valamint a Duna-Dráva Nemzeti Park Igazgatóságnak, hogy a kezelésük alá tartozó csodálatosan szép somogyi tájakon végezhettem eddigi vizsgálataimat.

Körmendi Sándornak és Heltai Miklósnak köszönöm hasznos lektori tanácsaikat, szigorú kritikájukat és segítőkészségüket, hogy mindig számíthattam rájuk.

Külön hálámat szeretném kifejezni sok évi önzetlen segítőkészségükért a Somogy Megyei Múzeumok Igazgatóságának Természettudományi Osztályán dolgozóknak, név szerint Juhász Magdolnának, Nagy Lórántnak, Simon Miklósnénak és Zsoldos Virágnak. Különösen köszönöm e kötet szerkesztőjének, Dr. Ábrahám Leventének, hogy a könyvem megjelenését kezdettől fogva támogatta, és hogy idôt, fáradságot nem kímélve végezte a források keresését és a szerkesztést.

Megtisztelö, hogy éppen a jövő generációi számára értékmegőrzést végző múzeum Natura Somogyiensis sorozatában jelenhettek meg kutatási eredményeim.

Szerencsésnek mondhatom magam, mert munkahelyemen, a Kaposvári Egyetemen a kissé rendhagyónak mondható kutatási téma művelését kezdettől fogva lehetővé tették számomra és megbecsültek általa.

Végül mérhetetlen hála illeti Családomat, hogy türelemmel viselték, amikor sokszor helyettük - ragadozókkal foglalkoztam.

A kutatómunka négy éves anyagi finanszírozását az Országos Tudományos Kutatási Alap (OTKA, F 023057) biztosította. A vizsgálatokat minden évben támogatta a Tudományos Életért Alapítvány (Somogy Megye Önkormányzata), a külföldi konferencia részvételeket a Soros Alapítvány, az OTKA, az Országos Müszaki és Fejlesztési Bizottság és az International Otter Survival Fund. A kutatómunkát támogatta továbbá az MTA Bolyai Ösztöndij Alap.

A Dráva folyó Somogy megyei térségének természeti monitoringját támogató DunaDráva Nemzeti Park Igazgatóság engedélyezte a vidra kutatása kapcsán kapott eredmények közzétételét. 


\section{Irodalomjegyzék}

ÁBRAHÁM, L. (szerk.) 1992: A Boronka-melléki Tájvédelmi Körzet élővilága. Dunántúli Dolgozatok (A) Természettudományi Sorozat, 7. kötet, Kaposvár.

AgYAKI G. 2000: A sakál napja. Magyar Vadászlap, 2: 10.

ALIEv F. F. 1969: Der kaukasische Schakal (Canis aureus moreoticus Geoffroy, 1835). Isvestija Zoologicheskij Institut Bulgarskaja Akademia Nauk 26: 75-82

Angelstam, P., Lindström, E., Widén, P. 1984: Role of predation in short-term population fluctuations of some birds and mammals in Fennoscandia. Oecologia 200-208.

AtÁNassov N. 1953: Untersuchungen über die Schakal (Canis aureus L.) in Bulgarien. Isvestija Zoologicheskij Institut Bulgarskaja Akademia Nauk 2: 189-273.

BÁldi, A., CsorbA, G., Korsós, Z. 1995: Magyarország szárazföldi gerinceseinek természetvédelmi szempontú értékelési rendszere. Magyar Természettudományi Múzeum, Budapest.

Begala, A., Lanszki, J., Heltai, M., Szemethy, L. 2000: Adatok néhány fontosabb hazai ragadozó táplálkozásáról. A Vadgazdálkodás Időszerú Tudományos Kérdései. 1: 28-37.

BeKoff, M., Daniels, T., Gittleman, J.L. 1984: Life history patterns and the comparative social ecology of carnivores. Ann. Rev. Ecol. Syst. 15: 191-232.

BERINKEY, L. 1966: Halak - Pisces. Akadémia Kiadó, Budapest.

BLANDFORD, P.R.S. 1987: Biology of the Polecat Mustela putorius: a literature review. Mammal Review, 17: 155-198.

BRANGI, A. 1995: Seasonal changes of trophic niche overlap in the stone marten (Martes foina) and the red fox (Vulpes vulpes) in a mountainous area of the Northern Appenines (Italy). Hystrix, 7: 113-118.

Brown, R., Ferguson, J., Lawrence, M., LeEs, D. 1993: Federn, Spuren und Zeichen der Vögel Europas: Ein Feldführer. Aula- verlag Wiesbaden

Buesching és MACDONALD, S.M. 1998: Implications of inter-specific food-competition between two sympatric carnivore species, the european badger (Meles meles) and the red fox (Vulpes vulpes), on population management. Euro-American Mammal Congress, Abstract: 325.

CARSS, D.N. 1995: Foraging behaviour and feeding ecology of the otter Lutra lutra: a selective review. Hystrix, 7: 179-194.

CARsS, D.N., Elston, D.A. 1996: Errors associated with otter Lutra lutra faecal analysis. II. Estimating prey size distribution from bones recovered in spraints. Journal of Zoology (London), 238: 319-332.

CARSS, D.N., Elston, D.A., Morley, H.S. 1998: The effects of otter (Lutra lutra) activity on spraint production and composition: implications for models which estimate prey-size distribution. Journal of Zoology (London), 244: 295-302.

CARss, D.N., Nelson, K.C. 1998: Cyprinid prey remains in otter Lutra lutra faeces: some words of caution. Journal of Zoology (London), 245: 238-244.

Carss, D.N., Parkinson, S.G. 1996:Errors associated with otter Lutra lutra faecal analysis. I. Assessing general diet from spraints. Journal of Zoology (London), 238: 301-317.

ChanIN, P.J. 1981: The diet of the otter and its relations with the feral mink in two areas of SouthWest England. Acta Theriologica, 26: 83-95.

CHANIN P.R.F. 1985: The natural history of otters. Croom Helm. London. 
Cheeseman, C.L., Cresswell, W.J., Harris, S., Mallinson, P.J. 1988: Comparison of dispersal and other movements in two badger (Meles meles) populations. Mammal Review, 18 (1): 51-59.

Clampalini, B., Lovari, S. 1985: Food habits and trophic niche overlap of the badger (Meles meles L.) and the red fox (Vulpes vulpes L.) in a Mediterranean coastal area. Zetschrift für Säugetierkunde 50: 226-234.

Clevenger, A.P. 1993a: Pine marten (Martes martes Linné, 1758) comparative feeding ecology in an island and mainland population of Spain. Zeitschrift für Säugetierkunde, 58: 212-224.

ClEVENGER, A.P. 1993b: Spring and summer food habits and habitat use of the European pine marten (Martes martes) on the island of Minorca, Spain. Journal of Zoology (London), 229: 153-161.

Clevenger, A.P. 1994: Feeding ecology of Eurasian pine martens and stone martens in Europe. in: Buskirk et al. (szerk). Martens, sables and fishers biology and conservation. Cornell University Press, Ithaca, London.

CsÁNYI, S. (szerk.) 1999: Vadgazdálkodási Adattár 1994-1998. GATE Vadbiológiai és Vadgazdálkodási Tanszék, Gödöllő.

CsÁNYI, S. (szerk.) 2000: Vadgazdálkodási Adattár 1999/2000. Szent István Egyetem Vadbiológiai és Vadgazdálkodási Tanszék, Gödöllő.

CsÁNYI, S. (szerk.) 2001: Vadgazdálkodási Adattár 2000/2001. Szent István Egyetem Vadbiológiai és Vadgazdálkodási Tanszék, Gödöllő.

Csorba, G., PeCSENYE, K. 1997: Nemzeti biodiverzitás-monitorozó rendszerek X. Emlősök és a genetikai sokféleség monitorozása. Magyar Természettudományi Múzeum, Budapest.

Dallas, J.F., Bacon, P.J., Carss, D.N., Conroy, J.W.H., Green, R., JefFeries, D.J., KrutK, H., Marshall, F., Piertney, S.B., RaCeY, P.A. 1999: Genetic diversity in the Eurasian Otter, Lutra lutra, in Scotland. Evidence from microsatellite polymorphism. Biological Journal of the Linnean Society, 68(1-2): 73-86.

Dallas, J.F., Carss, D.N., Marshall, F., Koepfli, K.P., Kruuk, H., Piertney, S.B., Bacon, P.J. 2000: Sex identification of the Eurasian otter Lutra lutra by PCR typing of spraints. Conservation Genetic, 1: 181-183.

DAY, M.G. 1968: Identification of hair and feather remains in the gut and faeces of stoats and weasels. Journal of Zoology (London), 148: 201-217.

DAY, M.G. 1978: Food habits of British stoats (Mustela erminea) and weasels (Mustela nivalis). Journal of Zoology (London), 155: 485-497.

Debrot, S., Fivaz, G., Mermod C, WeBer, J.-M. 1982: Atlas des poils des mammiferes d'Europe. Institut de Zoologie, Neuchatel.

Debrot, S., Fivaz, G., Mermod, C. 1984: Note sur le gite et la nourriture hivernale d'une hermine (Mustela erminea L). Bulletin de la societé neuchateloise des Sciences naturelles, 107: 137-141.

DELY, O.GY. 1983: Hüllők-Reptilia. Magyarország Állatvilága XX. kötet, Akadémiai Kiadó, Budapest.

DELIBES, M. 1978: Feeding habits of the stone marten, Martes foina (Erxleben, 1777), in northern Burgos, Spain. Zeitschrift für Säugetierkunde, 43: 282-288.

DEMETER A, KovÁcs GY. 1991: Állatpopulációk nagyságának és sủrüségének becslése. Akadémiai Kiadó, Budapest.

Demeter A., Spassov N. 1993: Canis aureus Linnaeus, 1758. [In: Handbuch der Säugetiere Europas. J. Niethammer and F. Krapp, eds]. Aula-Verlag Wiesbaden: 107-138.

Doncaster, C.P., Dickman, C.R., Macdonald, D.W. 1990: Feeding ecology of red fox (Vulpes vulpes) in the city of Oxford, England. Journal of Mammalogy. 71 (2): 188-194.

Dubuc, L.J., Owen, R.B., Krohn, W.B., Schell, C.J. 1991: Foods and distribution of river otters on Mount Desert Island, Maine. Transactions of the Northeast Section the Wildlife Society. 48: 104-112.

Dulfer, R. Roche, K. 1998: First phase report of the Trebon otter project. Scientific background and recommendations for conservation and management planning. Nature and environment, no. 93 Council of Europe Publishing, Strasbourg.

DuRBIN, L. 1989: Some responses of otters Lutra lutra to strange and familiar spraints. Lutra, 32: 132-138. 
ÉHIK GY. 1938: Jackal or reed-wolf from Hungary. Annales Naturales Historico Musei Nationalis Hungarici 31: 12-15.

ENGLUND, J. 1965: Studies on food ecology of the red fox (Vulpes vulpes) in Sweden. Viltrevy 3: 371-442.

ERDEI, M. 1977: Food -biological investigation on the fox populations in southern Hungary. Acta Biologica, Szeged, 23 (1-4): 97-107.

ERLINGE, S. 1967a: Food habits of the fish-otter Lutra lutra L. in South Swedish habitats. Viltrevy, 4: 371-443.

ERLINGE, S. 1967b: Home range of the otter Lutra lutra L. in southern Sweden. Oikos, 18: 186-209.

ERLINGE, S. 1968a: Territoriality of the otter Lutra lutra L. Oikos, 19: 81-98.

ERLINGE, S. 1968b: Food studies on captive otters (Lutra lutra L.). Oikos, 19: 259-270.

ERLINGE, S. 1969: Food habits of the otter Lutra lutra L. and the mink Mustela vison Schreber in a trout water in southern Sweden. Oikos, 20: 1-7.

ERLINGE, S. 1977: Spacing strategy in stoat Mustela erminea. Oikos, 28: 32-42.

ERLINGE, S. 1983: Demography and dynamics of a stoat Mustela erminea population in a diverse community of vertebrates. Journal of Animal Ecology, 52: 705-726.

Erlinge, S., Göransson, G., Hansson, L., Högstedt, G., Liberg, O., Nilsson, I.N., Nilsson, T.N., von Schantz, T., SYLvÉN, M. 1983: Predation as a regulating factor on small rodent populations in southern Sweden. Oikos, 40: 36-52.

FARAGó S. 1994: Vadászati állattan. In Köhalmi T. (szerk): Vadászati Enciklopédia. Mezőgazda Kiadó, Budapest.

FARAGó, S. 2002: Vadászati állattan. Mezőgazda Kiadó, Budapest.

FARKAS, D. 1983: Újabb adatok a róka táplálkozásáról. Beszámoló jelentés a Természet- és Vadvédelmi Állomás 1983. évi munkájáról, Fácánkert, 41-44.

GEIDEZIS, L. 1998: Diet of otters (Lutra lutra) in relation to prey availability in a fish pond area in Germany. VIIth International Otter Colloquium, Abstract: 21.

GellaI, T. 2002: Ha már nem félünk a farkastól, ne féljünk a sakáltól sem! Madártávlat, 4: 9.

GERA, P. 2001: Az európai vidra (Lutra lutra Linnaeus 1758) állományfelméréseinek összefoglaló jelentése 1995-2001: Alapítvány A Vidrákért, Budapest.

GERLAI R., BARABÁS Z. 1991: Etológiai példatár. Tankönyvkiadó, Budapest.

GIDAJATOV Y. H. 1965: [Seasonal number of jackals and foxes in Kizil-Agacko protected area]. Izvestiya Akademii Nauk Azerbaidzhanskoi SSR, Biologicheskih Nauk 3: 74-81

GITTLEMAN, J.L. 1985: Carnivore body size: ecological and taxonomic correlates. Oecologia, 67: 540-554.

GitTLEMAN, J.L. 1989: Carnivore group living: comparative trends. In: Carnivore behavior, ecology, and evolution. Ed by J.L. GitTLEMAN. New York: Cornell University Press. Pp. 183-207.

GoszCZYNSKI, J. 1977: Connections between predatory birds and mammals and their prey. Acta Theriologica, 22: 399-430.

GoszczYNSKI, J. 1986: Diet of foxes and martens in central Poland. Acta Theriologica 31: 491-506.

GosZCZYNSKI, J., JEDZEJEWSKA, B., JEDRZEJEWSKI, W. 2000: Diet composition of badger (Meles meles) in a pristine forest and rural habitats of Poland compared to other European populations. Journal of Zoology (London), 250: 495-505

GöRNER, M., HACKETHAL, H. 1987: Säugetiere Europas. Neumann Verlag Leipzig- Radebeul

GREeN, S.B., SALKIND, N.J., AKEY, T.M. 1997: Using SPSS for Windows: analyzing and understanding data. Prentice Hall, New Jersey.

HANSEN, M.H., JACOBSEN, L. 1999: Identification of mustelid species: otter (Lutra lutra), American mink (Mustela vison) and polecat (Mustela putorius), by analysis of DNA from faecal samples Journal of Zoology (London), 247: 177-181.

HARNA, G. 1993: Diet composition of the otter Lutra lutra in the Bieszczady Mountains, south-east Poland. Acta Theriologica, 38 (2) 167-174.

HARRINGTON, F.H., MECH, L.D. 1979: Wolf howling and its role in territory maintenance. Behaviour, 68 (3-4): 207-250.

Hell, P., RAJSKY, D. 2000: Immigrationen des Goldschakals in die Slowakei im 20. Jahrhundert. Beiträge zur Jagd- und Wildforschung, Bd. 25: 143-147. 
HELLDIN, O.J. 2000: Seasonal diet of pine marten Martes martes in southern boreal Sweden. Acta Theriologica, 45(3): 409-420.

HELTAI, M., LANSZKI, J., SzEMETHY, L. 2000a: Adalékok a vörösróka táplálkozásához. Vadbiológia, 7: 72-82.

Heltai M., SzemETHY L., Bíró Zs. 2000b: Új fajok a hazai faunában: az aranysakál (Canis aureus), a nyestkutya (Nyctereutes procyonoides) és a mosómedve (Procyon lotor) Magyarországon. Vadbiológia, 7: 63-71.

Heltai, M., SzEmethy, L., Bíró, Zs., Begala, A. 2000c: A veszettség elleni per-orális immunizáció hatása a rókaállomány dinamikájára. Magyar Állatorvosok Lapja. 122. 612-617.

Heltai, M.; SZEMETHY, L.; LANSZKI, J.; CsÁNYI S. 2000d: Returning and new mammal predators in Hungary: the status and distribution of the golden jackal (Canis aureus), raccoon dog (Nyctereutes procyonoides) and raccoon (Procyon lotor) in 1997-2000. Beträge zur Jagd- und Wildforschung, Bd. 26: 95-102.

HeLTAI, M. 2002: Emlős ragadozók magyarországi helyzete és elterjedése. Szent István Egyetem, Vadbiológiai és Vadgazdálkodási Tanszék, doktori disszertáció (kézirat).

HelTAI M, Szứcs E. 2002: Újra üvölt az aranysakál. Egy ragadozó visszatér. Búvár, 2: 34-35.

HeLTAI, M., Szứcs, E., LANSZKi J. 2002: Az aranysakál elterjedése és lehetséges vadgazdálkodási hatásai. Innováció, a tudomány és a gyakorlat egysége az ezredforduló agráriumában, Debrecen, 95-99.

HeLTAY I. 1989: A róka ökológiája és vadászata. Mezőgazdasági Kiadó, Budapest.

HERRERA, C.M. 1989: Frugivory and seed dispesal by carnivorous mammals, and associated fruit characteristics, in undisturbed Mediterranean habitats. Oikos, 55: 250-262.

HERRMANN, M. 1994: Habitat use and spatial organization by the stone marten. In BuskiRK et al. Eds/szerk: Martens, sables and fishers biology and conservation. Comell University Press, Ithaca, London.

Holisoví, V., Obrtel, R. 1982: Scat analytical data on the diet of urban stone martens, Martes foina (Mustelidae, Mammalia). Folia Zoologica, 31: 21-30.

HoRvÁTH GY. 1999: A Dráva felsô szakaszának térségére, "emlös objektumokra" (Mammalia) kidolgozott monitorozási tervezet. A monitoring vizsgálatokra kijelölt taxonok monitorozási protokollja. Janus Pannonius Tudományegyetem, Pécs.

Horváth Gy, Pintér, V. 2000: Small mammal fauna of two abandoned field habitats, and a spatio-temporal analysis of four rodent populations. Miscellanea Zoologica Hungarica 13: 105-121.

HYSLOP, E. J. 1980: Stomach contents analysis - a review of methods and their application. Journal of Fish Biology, 17: 411-429.

IsHuniN G. I. 1980: The boar, jackal, red fox and badger in the Aydarsk solonceks inundated by the waters of the Syr Daria. Bulletin of Moscow Society of Naturalist. Biological Series 85: 43-51.

JEDRZEJEWSKA, B., JEDRZEJEWSKI, W. 1998: Predation in vertebrate communities. The Bialowieza Primeval Forest as a Case Study. Springer-Verlag, Berlin Heildelberg, New York.

JeDRZEJEWsKi, W., JEDRZEJewsKA, B., SZYMURA, A. 1989: Food niche overlaps in a winter community of predators in the Bialowieza Primeval Forest, Poland. Acta Theriologica, 34: 487-496.

JedrzeJewski, W., Schmidt, K., Mirkowski, L., JedrzeJewsKa, B., OKARMA, H. 1993a: Foraging by lynx and its role in ungulate mortality: the local (Bialowieza Forest) and the Palaearctic viewpoints. Acta Theriologica, 38: 385-403.

JeDRZEJEWSKI, W., ZALEWSKI, A., JEDRZEJEWSKA, B. 1993b: Foraging by pine marten Martes martes in relation to food resources in Bialowieza National Park, Poland. Acta Theriologica, 38: 405-426.

JEFFERIES, D.J. 1985: The value of otter Lutra lutra surveying using spraints: an analysis of its successes and problems in Britain. Otters, Journal of the Otter Trust, 1(9): 25-32.

Jensen B., SEQueIra D.M. 1978: The diet of the red fox (Vulpes vulpes L.) in Denmark. Danish Review of Game Biology 10: -16.

JuHÁsz, M. 1998: A Duna-Dráva Nemzeti Park részletes botanikai felmérése. Somogy megyei szakasz 3. Lankóci-erdő. Jelentés, Somogy Megyei Múzeum, Kaposvár. 
KANCHANASAKA, B. 1998: Feeding ecology of three otter species in the upper Khawe Yai River, Thung Yai Naresuan Wildlife Sanctuary, Thailand. VIIth International Otter Colloquium, Abstract: 12.

KEMENES, K. I. 1988: Egy fokozottan védett ragadozó a vidra (Lutra lutra) magyarországi elterjedésének és táplálkozásának vizsgálata. I. Magyar Ökológus Kongresszus, Előadáskivonatok és poszter összefoglalók, Budapest, 92.

KemenEs, K. I. 1993: Egy védett ragadozó, a vidra (Lutra lutra) elterjedése, táplálkozása és az ezeket befolyásoló tényezők Magyarországon. Kandidátusi értekezés.

KemenEs, K. I., NeCHAY, G. 1990: The food of otters Lutra lutra in different habitats in Hungary. Acta Theriologica, 35: 17-24.

Kemenes, I., Demeter, A. 1994: Uni- and multivariate analyses of the effects of environmental factors on the occurrence of otters (Lutra lutra) in Hungary. Annales Historico-Naturales Musei Nationalis Hungarici, 86: 139-143.

Kemenes, I., Demeter, A. 1995: A predicive model of the effect of environmental factors on the occurrence of otters (Lutra lutra L.) in Hungary. Hystrix, 7: 209-218.

King, C.M., FluX, M., InNes, J.G., FitzGerald, B.M. 1996: Population biology of small mammals in Pureore Forest Park: 1. Carnivores (Mustela erminea, M. furo, M. nivalis, and Felis catus). New Zealand Journal of Ecology, 20: 241-251.

KLoskowski, J., Grendel, A., WronkA, M., 2000: The use of fish bones of three farm fish species in diet analysis of the Eurasian otter, Lutra lutra. Folia Zoologica 49: 183-190.

KNOLLSEISEN, M. 1996: Fischbestimmungsatlas, als Grundlage für nahrungsökologische Untersuchungen. Boku-Reports on Wildlife Research and Game management, Wien.

KolB, H.H., Hewson, R. 1979: Variation in the diet of foxes in Scotland. Acta Theriologica, 24: 69-83.

Kolb, H.H., Hewson, R. 1980: The diet and growth of fox cubs in two region of Scotland. Acta Theriologica, 25: 325-331.

KozENA, I. 1988: Diet of the red fox (Vulpes vulpes) in agrocoenoses in southern Moravia. Acta Sc. Nat. Brno, 22 (7): 1-24.

KraNZ, A. 2000: Otters (Lutra lutra) increasing in Central Europe: from the threat of extinction to locally perceived overpopulation? Mammalia, 64: 357-368.

KrEBS, C.J. 1989: Ecological methodology. Harper Collins Publishers, New York.

KruUK, H., Parish T. 1981: Feeding specialization of the European badger Meles meles in Scotland. Journal of Zoology (London), 50: 773-778.

KruUK, H. 1989: The social badger - Ecology and behaviour of a group-living carnivore (Meles meles). Oxford Univ. Press.

KRUUK, H, BALHARRY, D. 1990: Effects of sea water on thermal insulation of the otter, Lutra lutra. Journal of Zoology (London), 220: 405-415.

KRUUK, H., CONROY, J.W.H. 1987: Surveying otter Lutra lutra populations: a discussion of problems with spraints. Biological Conservation, 41: 179-183.

KrutK, H. Moorhouse, A. 1990: Seasonal and spatial differences in food selection by otters (Lutra lutra) in Shetland. Journal of Zoology (London), 221: 621-637.

KruUK, H., WansinK, D., MoORHouse, A. 1990: Feeding patches and diving success of otters, Lutra lutra, in Shetland. Oikos, 57: 68-72.

KruUK, H., CONRoY, J.W.H., MoORHouse A. 1991: Recruitment to a population of otters (Lutra lutra) in Shetland, in relation to fish abundance. Journal of Applied Ecology, 28: 95-101.

KruUK, H. 1995: Wild otters. Predation and population. Oxford University Press, Oxford.

MACDONALD, D.W. 1980: Patterns of scent marking with urine and faeces amongst carnivore communities. Symp. Zool. Soc. Lond., 45: 107-139.

MacdonaLD, D.W. 1983: The ecology of carnivore social behaviour. Nature, 301: 379-383.

MACDONALD, D. W., BarRETT, P. 1993: Mammals of Britain and Europe. London, Glasgow, New York, Harper Collins Publishers.

MadSEn, A.B., Rasmussen, A.M. 1985: Reproduction in the stone marten Martes foina in Denmark. Natura Jutlandica, 9: 145-148. 
Mason, C.F., Macdonald, S.M. 1986: Otters: ecology and conservation. Cambridge Univ. Press, Oxford.

MARChESI P., MermoD, C. 1989: Régime alimentaire de la martre (Martes martes L.) dans le Jura suisse (Mammalia: Mustelidae). Revue suisse Zool. 96 (1): 127-146.

MÄRZ, R. 1972: Gewöll- und Rupfungskunde. Akademie Verlag, Berlin.

Mills, S.L., CitTA, J.J., Lair, K.P., Schwartz, M.K., Tallmon, D.A. 2000: Estimating animal abundance using noninvasive DNA sampling: promise and pitfalls. Ecological Applications, 10: 283-294.

Mitchell-Jones, A.J., Amori, G., Bogdanowicz, W., Krystufek, B., Reinders, P.J.H., Stubbe, M., Thissen, J.B.M., Vohralík, V., ZIMA, J. 1999: The atlas of European mammals. T\&AD Poyser Ltd., London.

Mócż́r, L. 1969: Állathatározó I-II. kötet. Tankönyvkiadó, Budapest.

Moreno, S., RodrigueZ, A., Delibes, M. 1988: Summer foods of the pine marten (Martes martes) in Majorca and Minorca, Balearic Islands. Mammalia, 52: 289-291.

Mowat F. 1963/ford. 1976: Never cry wolf. (Ne féljünk a farkastól). Háttér Kiadó, Budapest.

NAGY, D. 1999: Adatok a vidra (Lutra lutra) táplálékösszetételéröl a Balaton és a Kis-Balaton néhány élőhelyén. Diplomadolgozat, ELTE, Budapest.

Neal, E., Cheeseman, C. 1996: Badgers. T \& A.D. Poyser Natural History, London.

Pandolfi, M., Marinis DE, A.M., Petrov, I. 1996: Fruits as a winter feeding resource in the diet of Stone marten (Martes foina) in east-central Italy. Zeitschrift für Säugetierkunde, 61: 215-220.

Papageorgiou, N.K., Sepougaris, A., Christopoulou, O.G., Vlachos, C.G., Petamidis, J.S. 1988: Food habits of the red fox in Greece. Acta Theriologica, 33: 313-324.

PAunovic, M. 1990: Vodozemci iz proslosti I sadasnjosti Odredivanje skeletnih dijelova. (Kétéltú határozó csonttani bélyegek alapján), Zagreb.

Pedrini, P., Prigioni, C., Volcan, G. 1995: Use of trophic resources and habitats by the genus Martes in Adamello-Brenta Park (Central Italian Alps). Hystrix, 7: 127-135.

Peters, R., Mech, L.D. 1978: Scent marking in wolves. In: Hall, R.L., SharP, H.S. (szerk): Wolf and man: evolution in parallel. Academic Press, New York, 133-148.

PIELKowski, Z. 1976: The role of foxes in the reduction of the European hare population. Ecology and management of European hare population, Warsaw, $133 \mathrm{p}$.

PigozZI, G. 1988: Diet of the European badger (Meles meles L.) in the Maremma Natural Park, Central Italy. Mammal Review, 18 (1): 73-75.

PigozzI, G. 1991: The diet of the Eurasian badger in a Mediterranean coastal area. Acta Theriologica, 36: 293-306.

PinTÉR, K. 1989: Magyarország halai. Akadémiai Kiadó, Budapest.

Posillico, M., SerafinI, P., Lovari, S. 1995: Activity patterns of the stone marten Martes foina Erxleben, 1777, in relation to some environmental factors. Hystrix, 7: 79-97.

PrécsénYi I., BaRTA Z., KARSAI I., SzÉKely T. 1995: Alapvetố kutatástervezési, statisztikai és projectértékelési módszerek a szupraindividuális biológiában. KLTE, Debrecen.

Prigioni, C., Fumagalli, R., Schirru, L, Carugati, C. 1995: Sprainting activity of captive otters: its relationship with breeding cycle and number of animals. Hystrix, 7: 297-301.

Pulliainen, E. 1980: Winter habitat selection, home range and movements of the pine marten (Martes martes) in a Finnish lapland forest. Woldwide Furbearer Conference, Proceeding, 1068-1087.

Pulliainen, E. 1981: A transect survey of small land carnivore and red fox populations on a subarctic fell in Finnish Forest Lapland over 13 winters. Annales Zoologici Fennici, 18: 270-278.

Pulliainen, E. 1982: Scent-marking in the pine marten (Martes martes) in Finnish Forest Lapland in winter. Zeitschrift für Säugetierkunde, 47: 91-99.

Pulliainen, E., OllonmäKI, P. 1996: A long-term study of the winter food niche of the pine marten Martes martes in northern boreal Finland. Acta Theriologica, 41 (4): 337-352.

RAKONCZAY, Z. (szerk.) 1989: Vörös Könyv. Akadémiai Kiadó, Budapest: 62-64

Rasmussen A.M., MADSEN, A.B. 1985: The diet of the stone marten Martes foina in Denmark. Natura Jutlandica, 8: 141-144.

ReIcHHoLf, J. 1983: Säugetiere. Mosaic Verlag GmbH, München. 
REID, D.G., BAYER, M.B., CODE, T.E., McLEAN, B. 1987: A possible method for estimating river otter, Lutra canadensis, population using snow tracks. Canadian Field-Naturalist, 101 (4): 576-580.

REIG, S., JEDRZEJEWSKI W. 1988: Winter and early spring food of some carnivores in the Bialowieza National Park, eastern Poland. Acta Theriologica, 33: 57-65.

Reuther, C., Kölsch, O., JANßEN, W. (Eds.) 2000: Surveying and monitoring distribution and population trends of the Eurasian otter (Lutra lutra). Habitat 12., IUCN/SSC Otter Specialist Group, GN-Gruppe Naturschutz GmbH, Hankensbüttel.

REYNOLDS, J.C., AEBISCHER, N. J. 1991: Comparison and quantification of carnivore diet by faecal analysis: a critique, with recommendations, based on a study of the Fox Vulpes vulpes. Mammal Review, 21. 3. 97-122.

RoBSON M.S., HUMPHREY, S.R. 1985: Inefficiacy of scent-stations for monitoring river otter populations. Wildlife Society Bulletin, 13: 558-561.

Ryszkowski, L., KeNYon WAGNER, C., GoszCZYNSKI J., TruszkowsKi J. 1971: Operation of predators in a forest and cultivated fields. Annales Zoologici Fennici, 8: 160-168.

Sales-Luis, T., Pedroso, N., Santos-Reis, M. 1998: Comparative analysis of the diet of the eurasian otter in a hydroelectric dam and associated tributaries in Portugal. Euro-American Mammal Congress, Abstract: 325.

SARMENTO, P., CRUZ, J. 1998: Predation by a community of Carnivores on a wild rabbit population. Euro-American Mammal Congress, Abstract: 333.

SASVÁRI, L. 1986: Madárökológia II. kötet. Akadémiai Kiadó, Budapest.

SCHMIDT, E. 1967: Bagolyköpet vizsgálatok. A Magyar Madártani Intézet kiadványa, Budapest.

SELER, A., KRÜGER, H.H., FEStETICS, A. 1994: Reaction of a male stone marten (Martes foina Erxleben, 1777) to foreign faeces within its territory: a field experiment. Zeitschrift für Säugetierkunde, 59: 58-60.

SERAFINI, P., LovaRI, S. 1993: Food habits and trophic niche overlap of the red fox and the stone marten in a Mediterranean rural area. Acta Theriologica, 38 (3) 233-244.

Sidorovich, V. 1997: Mustelids in Belarus. Zolotoy uley publisher, Minsk.

SIMON P. 1996: Az aranysakál (Canis aureus). Nimród 84: 46.

SKARÉN, U. 1993: Food of Lutra lutra in central Finland. IUCN Otter Spec. Group Bull. 8: 31-34.

Soó, R., KÁRPÁTI Z. 1968: Növényhatározó. II. kötet. Tankönyvkiadó, Budapest.

STEEL, R. G. D., ToRRIE, J.H. 1980: Principles and procedures of statistics. McGraw-Hill Publishing Co. 592-593.

Stenin, G., Kolen, N., Mrtov, I. 1983: [Some aspects of jackals's dispersion]. Lovno I ribno stopanstvo: 7.

STORCH, I., LinDSTRÖM, E., JOUNGE, J. 1990: Diet and habitat selection of the pine marten in relation to competition with the red fox. Acta Theriologica, 35 (3-4): 311-320.

STRAuSs, R.E. 1979: Reliability Estimates for Ivlev's Electivity Index, The Forage Ratio, and a Proposed Linear Index of Food Selection. Transactions of the American Fisheries Society, 108: 344-352.

Suchentrunk, F. 1984: Aspects of food ecology of some austrian red fox population (Vulpes vulpes) and possible consequence for the spread of rabies. Dissertation, Wien

Sulkava, R. 1996: Diet of otters Lutra lutra in central Finland. Acta Theriologica, 41: 395-408.

SzABó Á., HeLTaI M., LANSzKi J. 2001: A hiúz és a farkas táplálék-összetétele Magyarországon. Vadbiológia, 8: 77-83.

SzEDERJEI Á. 1961: Vadesapáson. Mezőgazdasági Kiadó, Budapest.

SzÉKY, P. 1983b: Nagyság, testarányok és teljesítmény az állatvilágban. In A biológia aktuális problémái 28. kötet, Medicina Kiadó, 137-207.

SzÉKY, P. 1986: A ragadozó és zsákmánya közötti kölcsönhatások ökológiája. In A biológia aktuális problémái 35. kötet, Medicina Kiadó, 203-273.

SzEMETHY, L., HelTAI, M. 1996: Néhány védett emlös ragadozó faj helyzete Magyarországon, 1987-1994. Vadbiológia, 5: 1-17.

SZEMETHY, L., HeLTAI, M., Bíró, Zs., RITTER, D. 1998: Long-term predator monitoring in Hungary. Euro-American Mammal Congress, Abstract: 334. 
SzEmEthy, L., HeltaI, M. 2000a: Ragadozó-gazdálkodás: az elmélet összekapcsolása a gyakorlattal. A Vadgazdálkodás Időszerú Tudományos Kérdései. 1: 81-88

SzEMETHY, L., HeltaI, M. 2000b: A vadgazdálkodás törvényes lehetőségei a ragadozókkal való együttélésben. A Vadgazdálkodás Időszerú Tudományos Kérdései. 1: 89-99.

SzEMETHY L., Heltai M., CsÁNYI S. 2000: A hazai szőrmés és szárnyas ragadozók helyzete az elmúlt évtizedekben a vadászati statisztikák és monitoring programok alapján. A Vadgazdálkodás Időszerứ Tudományos Kérdései. 1: 51-61.

SzEmethy L., Heltai M. 2001: A csapdázás elmélete és gyakorlata. A csapdázás alkalmazási lehetőségei a XXI. század vadgazdálkodásában. Vad-ész Mérnökiroda Bt., Gödöllő.

TANKó, I, TASSI, I. 1978: A vidra életmódjáról és halászati kártételéról. Halászat, 71: 72-75p.

TAPPER, S.C. 1976: The diet of weasel, Mustela nivalis and stoat, Mustela erminea during early summer, in relation to predation on gamebirds. Journal of Zoology (London), 179: 219-224.

TARYANnIKov, V. I. 1974: Feeding of Canis aureus aureus in the Syrdarja Basin. Zoologiceskij Zhournal (Moskva), 53: 1539-1547.

TEERINK, B.J. 1991: Hair of West-European mammals. Cambridge University Press, Cambridge.

TESTER, U. 1986: Vergleichende Nahrungsuntersuchung beim Steinmarder Martes foina (Erxleben, 1777) in gro städtischem und ländlichem Habitat. Säugetierkundliche Mitteilungen, 33: 37-52.

Tóth-AғÁthy, M. 1998: Data to the diet of the urban Stone marten (Martes foina Erxleben) in Budapest. Opusculla Zoologica, Budapest, XXXI: 113-118.

TóTHMÉRÉSZ, B. 1996: NuCoSa: programcsomag botanikai, zoológiai és ökológiai vizsgálatokhoz. Scientia Kiadó, Budapest.

TRENSE, W. 1989: The big game of the World. Verlag Paul Parey, Hamburg and Berlin: 1-413.

UjHELYI, P. 1989: A magyarországi vadonélő emlősállatok határozója. (Küllemi és csonttani bélyegek alapján). A Magyar Madártani Egyesület kiadványa, Budapest.

Yom-Tov, Y., AsHKENAZI, S., VINER, O. 1995: Cattle predation by the golden jackal Canis aureus in the Golan Heights, Israel. Biological Conservation 73: 19-22.

VÁsÁRHELYI, I. 1958: Hasznos és káros vademlösök. Élet és Tudomány Kiskönyvtár. Gondolat Kiadó, Budapest.

WAECHTER, A. 1975: Ecologie de la fouine en Alsace. Terre et Vie, 29: 399-457.

WEBER, J.-M. 1990: Seasonal exploitation of amphibians by otters (Lutra lutra) in north-east Scotland. Journal of Zoology (London), 220: 641-651.

WISE, M. H. 1980: The use of fish vertebrae in scats for estimating prey size of otters and mink. Journal of Zoology (London), 192: 25-31.

WISE M. H., LINN I. J., KENNEDY C.R. 1981: A comparison of the feeding biology of mink Mustela vison and otter Lutra lutra. Journal of Zoology (London), 195: 181-213.

ZALEWSKI, A., JEDRZEJEWSKI, W., JEDRZEJEWSKA, B. 1995: Pine marten home ranges, numbers and predation on vertebrates in a deciduous forest (Bialowieza National Park, Poland). Annales Zoologici Fennici, 32: 131-144.

ZALEWSKI, A. 1997a: Patterns of resting site use by pine marten Martes martes in Bialowieza National Park (Poland). Acta Theriologica, 42: 153-168.

ZALEWSKI, A. 1997b: Factors affecting selection of resting site type by pine marten in primeval deciduous forests (Bialowieza National Park, Poland). Acta Theriologica, 42: 271-288.

ZALEWSKI, A. 2000: Factors affecting the duration of activity by pine martens (Martes martes) in the Bialowieza National Park, Poland. Journal of Zoology (London), 251: 439-447.

ZALEWSKI, A. 2001: Seasonal and sexual variation in diel activity rhythms of pine marten Martes martes in the Bialowieza National Park. Acta Theriologica, 46: 295-304.

ZAR, J.H. 1996: Biostatistical analysis. Prentice-Hall International Inc. 
Mellékletek 
1. melléklet: A Magyarországon előforduló ragadozó emlősök jellemzői

(Gittleman 1985, 1989 alapján, kiegészítésekkel)

Aktivitási mintázat (fó̉ aktivitási idószzak): $\mathrm{N}=$ nokturnális, $\mathrm{D}=$ diumális, $\mathrm{A}=$ aritmikus, $\mathrm{C}=$ lrepuszkuláris, $\mathrm{O}=$ nokturnális és krepuszzkuláris;

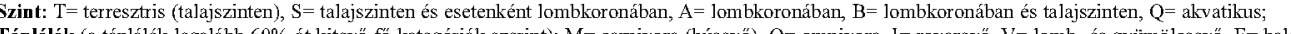

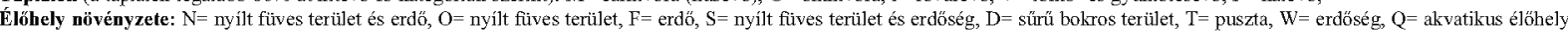
Földrajzi szêlesség: a faj földrajzi elterjedése alapján számolt átlagos szélesség

Napi vadászít $(\mathrm{km})$

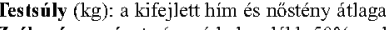

Jín kifejlett ragadozók esetében): V= nagyon kicsi $(<1 \mathrm{~kg})$, S= kicsi $(1-10 \mathrm{~kg})$, M= közepes $(10-100 \mathrm{~kg})$, L= nagy $(100-400 \mathrm{~kg})$

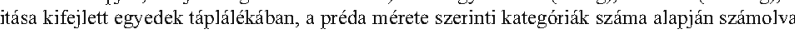

"A Magyarországon elöforduló nyest és a mezei görény nem szerepel az eredeti müben, a táblázat kiegészitése saját adatok alapján történt.

\begin{tabular}{|c|c|c|c|c|c|c|c|c|c|c|c|}
\hline$\overline{F a j}$ & $\begin{array}{c}\text { Aktivitási } \\
\text { mintázat }\end{array}$ & Sxint & Táplálék & Növényzet & $\begin{array}{c}\text { Föld rajzi } \\
\text { széless ég }\end{array}$ & $\begin{array}{c}\text { Napi } \\
\text { vadászút }\end{array}$ & Testsúly & $\begin{array}{c}\text { Zsákmány } \\
\text { mérete }\end{array}$ & $\begin{array}{l}\text { Préda } \\
\text { s záma }\end{array}$ & $\begin{array}{l}\text { A lom- } \\
\text { nagysá á }\end{array}$ & $\begin{array}{l}\text { Csoport- } \\
\text { nagyság }\end{array}$ \\
\hline Farkas & A & $\mathrm{T}$ & $\mathbf{M}$ & $\mathbf{N}$ & 40 & 17,5 & 33,2 & $\mathbf{M}$ & 3 & 8 & 7 \\
\hline Aranys akál & o & $\mathrm{T}$ & $\mathrm{O}$ & 0 & -10 & - & 8,8 & V & 1 & 3 & 3 \\
\hline Vörös róka & $\mathrm{N}$ & $\mathrm{T}$ & M & $\mathbf{F}$ & 34 & - & 4,1 & $\mathrm{~V}$ & 2 & 5 & 3 \\
\hline Nyes tku tya & $\mathbf{N}$ & $\mathrm{T}$ & $\mathrm{O}$ & $\mathbf{F}$ & - & - & 7,2 & V & 2 & & \\
\hline (Barn amedve)* & A & $\mathrm{T}$ & $\mathrm{v}$ & $\mathrm{N}$ & - & 8,8 & 298,9 & - & - & 2 & 1 \\
\hline Mosómedve & o & $\mathrm{T}$ & $\mathrm{O}$ & S & 36 & 1,14 & 6,4 & $\mathrm{~V}$ & 2 & 4 & 1 \\
\hline Hermelin & A & $\mathrm{T}$ & $\mathbf{M}$ & $\mathbf{F}$ & 47 & 2,97 & $0,95(0,2)$ & V & 2 & 5 & 1 \\
\hline Men yét & A & $\mathrm{T}$ & $\mathbf{M}$ & $\mathbf{S}$ & 45 & 1,99 & 0,08 & V & 2 & - & 1 \\
\hline (Euró pai nyérc)* & $\mathrm{O}$ & - & $\mathbf{M}$ & $\mathbf{F}$ & - & - & 0,59 & V & - & - & - \\
\hline (Kanadainyérc) & $\mathrm{N}$ & - & $\mathbf{M}$ & $\mathbf{F}$ & 28 & - & 0,91 & $\mathrm{~V}$ & 2 & 5 & 1 \\
\hline Közöns.gö rény & $\mathbf{N}$ & $\mathbf{S}$ & $\mathbf{M}$ & $\mathbf{F}$ & - & - & 1,03 & V & 1 & & \\
\hline Nyus $\pi$ & $\mathrm{N}$ & B & $\mathbf{M}$ & $\mathbf{F}$ & - & 16,8 & 1,20 & $\mathrm{~V}$ & - & 3 & 1 \\
\hline Borz & $\mathrm{O}$ & $\mathrm{T}$ & I & $\mathbf{S}$ & - & - & 11,6 & V & 1 & 3 & 7 \\
\hline Vidra & $\mathrm{N}$ & $Q$ & $\mathrm{~F}$ & Q & - & - & 8,8 & V & 1 & - & - \\
\hline Vadmacs ka & A & $\mathrm{T}$ & $\mathbf{M}$ & $\mathbf{F}$ & - & - & 4,67 & V & 3 & 3 & 1 \\
\hline Hiúz & A & $\mathrm{T}$ & M & $\mathbf{F}$ & 45 & 8.0 & 11,3 & $\mathbf{S}$ & 3 & 2 & 1 \\
\hline \multicolumn{12}{|l|}{ Kiegés źtés ek ${ }^{* *}$} \\
\hline Nyest & $\mathrm{O}$ & $\mathbf{S}$ & $\mathrm{O}$ & $\mathbf{N}$ & - & - & 1,6 & V & 2 & 3 & 1 \\
\hline Mezeigörény & N? & $\mathrm{T}$ & $\mathrm{M}$ & 0 & - & - & - & $\mathrm{V}$ & 1 & - & - \\
\hline
\end{tabular}


2. melléklet: A terresztris ragadozók préda fajainak besorolása súlyuk és jellemző előfordulásuk (élőhelyük és élőhelyi kötődésük) alapján

Gerinctelenek:

1, t, m: szöcske (Tettigonidea spp.), lótücsök (Gryllotalpa gryllotalpa), gyászfutó (Pterostichus spp.), fémfutó (Harpalus spp.), futóbogár (Carabidae spp.), pattanóbogár (Elateridae spp.), aranyos rózsabogár (Cetonia aurata), rózsabogár (Cetonia spp.) májusi cserebogár (Melolontha (Carabidae spp.), pattanóbogár (Elateridae spp.), aranyos rózsabogár (Cetonia aurata), rózsabogár (Cetonia spp.) májusi cserebogár (Melolontha
melolontha), cserebogár (Melolonthidae spp.), bogár (Coleoptera spp.), bogár lárva (Coleoptera spp.), kék fadongó (Xylocopa valga), német darázs melolontha), cserebogár (Melolonthidae spp.), bogar (Coleoptera spp.), bogár lárva (Coleoptera spp.), kék fadongó (Xylocopa valga), némét darázs
(Paravespula germanica), lódarázs (Vespa crabro), darázs (Vespidae spp.) darázs (Vespidae spp.) lárva, háziméh (Apis mellifera), hártyásszárnyú (Paravespula germanica), lódarázs (Vespa crabro), darázs (Vespidae spp.) darázs (Vespidae s
(Hymenoptera spp.), rovar (Insecta spp.), rovar lárva (Insecta spp.), csiga (Gastropoda spp.),

Hymenoptera spp.), rovar (Insecta spp.), rovar lárva (Insecta spp.), csiga (Gastropoda spp.),
1, t, vé: aranypettyes futrinka (Carabus hortensis), ragyás/rezes futrinka (Carabus spp.), kélfutrinka (Carabus violaceus), börfutrinka (Carabus coriaceus), aranyos bábrabló (Carabus sycophanta), szarvasbogár (Lucanus cervus), tavaszi ganéjtúró (Geotrupes vernalis), erdei-/közönséges galacsinhajtó (Geotrupes spp.), galacsinhajtó (Scarabeidae spp.), erdei vöröshangya (Formica rufa)

1, $\mathbf{i}, \mathbf{h}$ : padlásdarázs (Polistes nimfa),

1, t: mezei tuicsök (Gryllus campestris), imádkozó sáska (Mantis religiosa), közönséges bodobács (Lygaesoma reticulata), változó futrinka (Carabus scheidleri), grabonafutrinka (Zabrus tenebrioides), futóbougr lírva (Carabidae spp), kis szarvasbogá (Dorcus parallelepipedus), virágcincér (Leptura spp.), nagy hőscincér (Cerambyx cerdo), cincér (Cerambycidae spp.), hétpettyes katicabogár (Coccinella septempunctata), katicabogár (Coccinella spp.), csalán levélbogár (Dlochrysa fastuosa), levélbogár (Chrysomelidae spp.), temetöbogár (Necrophorus spp.), szalagos méhészbogár (Trichodes apiarius), díszbogár (Buprestidae spp.), ormányosbogár (Curculionidae spp.), hangya (Formica spp.), poszméh (Bombus spp.), darázs fészek (Vespidae spp.), szitakötő (Odonata spp.) lepke báb (Lepidoptera spp.), ikerszelvényes (Diplopoda spp.), ászkarák (Isopoda spp.), Nagy balogcsiga (Aplexa hynorum), kerti-/ligeti csiga (Cepaea spp.), puhatestú (Gastropoda spp.), gyủrűsféreg (Annelida spp.),

1, v: sárgaszegélyủ csíkbogár (Ditiscus marginalis), óriás csibor (Hydrous piceus), szitakötỏ lárva (Odonata spp.), tízlábú rák (Decapoda spp.),

Jelmagyarázat: A zsálmány súlykategóriái: 1 - 15 g alatt, 2 - 15-50 g, 3-51-100 g, 4 - 101-300 g, 5 - 300 g felett.

A zsákmány jellemzö elöfordulási szintje: $\mathrm{t}$ - talajszinten, valamint jellemzöen talajszinten, de esetenként bokrokon, fákon is (ide sorolva az elhullott példányból, ill. âllatvágásból fogyasztás); bf - bokron és fán, valamint jellemzöen bokron és fán, de esetenként talaiszinten is (ide sorolva az eresz alatt, illetve épületekben magasan élö egyedek fogyasztása is); v - vizes élöhelyen (vízi és vízhez kötödö).

A zsákmány jellemzỏ élőhelyi kötődése (csak a nyest táplálékban előforduló fajoknál feltüntetve): h - házhoz, ill. emberhez kötődoö; vé - vadon élő; $\mathrm{m}$ - vegyes.

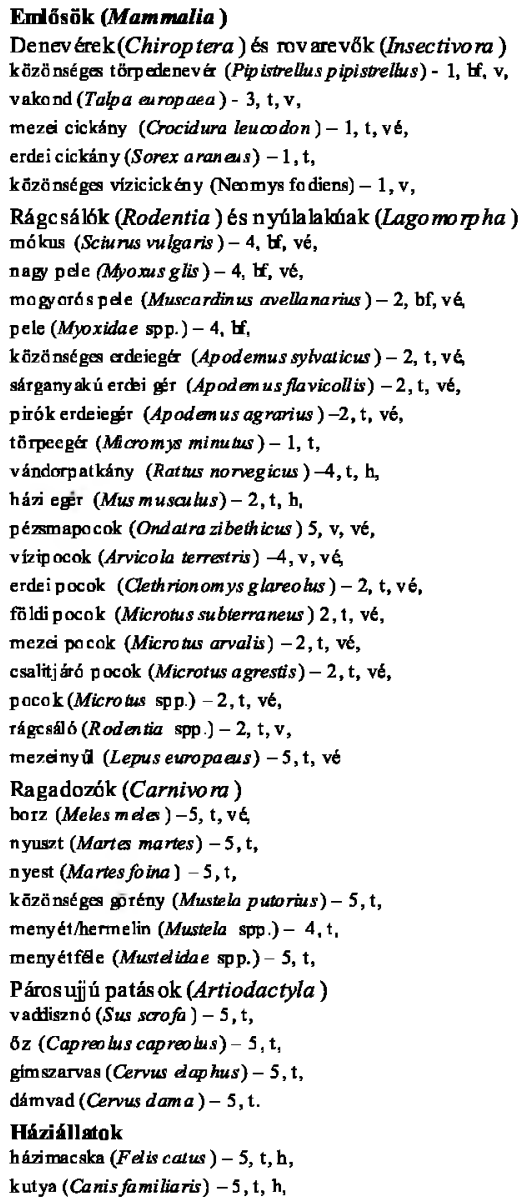


3. melléklet: A vidra évszakonkénti táplálék-összetétele a Fonói tavon és a Boronka-melléki Tájvédelmi Körzetben

Megjegyzés: * részletes haltáplálék-összetétel a 4-6. mellékletben található

\begin{tabular}{|c|c|c|c|c|c|c|c|c|}
\hline \multirow{3}{*}{ Táplálék k ta son } & \multicolumn{4}{|c|}{\begin{tabular}{|l|} 
Fonó ihalastó 1991-97 \\
\end{tabular}} & \multicolumn{4}{|c|}{ Bomnka-melléki TK 1997-98 } \\
\hline & \begin{tabular}{|c|} 
TÉ \\
\end{tabular} & Thvas? & Nyár & $\bar{\delta}_{\mathrm{az}}$ & Tél & Tavas $\mathrm{z}$ & Nyár & $\delta_{\mathrm{Az}}$ \\
\hline & \multicolumn{8}{|c|}{ Relatf́v elö fordulás i gy akoris ág, \% } \\
\hline Kis- da kñze pes emlhank & $\overline{0,7}$ & 2,5 & $\mathbf{1 , 3}$ & (n,s & 0,3 & 1,5 & 1,6 & 0,4 \\
\hline Cickány (Soricidae spp.) & 0,1 & & & & & & & \\
\hline Kõ ×ŏnsçges erdeiegér (Apodemus syluaticus) & 0,1 & & & & & & 0,5 & \\
\hline Sárgan yakú erdeiegţ (Apodemus flavio collis) & & 0,2 & 0,3 & & & & & \\
\hline Erdeiegér (Apodem us spp.) & & 0,6 & 0,5 & & & 0,3 & & \\
\hline Vándorp atkány（Ratuss norvegiaus） & & & & 0,2 & & & & \\
\hline Pésmapank (Ondutra zibethicus) & 0,4 & & & 0,2 & & & & \\
\hline Vizipocok (Arvicola lerestris) & & 1,0 & & & & & & \\
\hline Ercki pocok (Cethrionomys glareolus) & & 0,2 & 0,2 & & 0,3 & 0,6 & 0,5 & 0,4 \\
\hline Mezzi poonk (Merous arvalis) & 0,1 & & & 0,2 & & & & \\
\hline Rágcsáló (Rodentia spp.) & & 0,3 & 0,3 & 0,2 & & 0,6 & 0,6 & \\
\hline Merrinyúl (Lepus europaeus) & & 0,2 & & & & & & \\
\hline (Ed hullontt nagyem láa) Cañlkña vad & - & - & 0,2 & - & - & - & - & - \\
\hline O. (Capren us capreouss) & & & 0,2 & & & & & \\
\hline Madarak & 1,3 & 3,9 & 11,3 & 1,8 & 0,3 & $\mathbf{3 , 2}$ & 5,5 & 2,1 \\
\hline Tengelic (Carduelis carduedis) & & & 0,2 & & & & & \\
\hline Seregély (Stumus ulgaris) & & & & & & 0,3 & & \\
\hline Ki islestú én ckesmadár (Passeríformes spp.) & $1, \mathbf{3}$ & 3,5 & 9,6 & 1,6 & 0,3 & 2,9 & 5,5 & 1,1 \\
\hline Fáćńn (Phasianus colchicus) & & & 0,3 & 0,2 & & & & \\
\hline Vizityúk (Gallinula chloropus) & & 0,2 & & & & & & \\
\hline R\&e (Anas spp.) & & & & & & & & 0,6 \\
\hline Szárcsa (Fulica atra) & & 0,2 & 0,2 & & & & & 0,4 \\
\hline Honllōk k+kétéltifie k & 18,5 & 16,4 & $16, n$ & 6,8 & 2,4 & 12,2 & 12,6 & 3,1 \\
\hline Vizisik1b (Natrix natrix ) & & 0,3 & 0,8 & 0,5 & & 0,3 & & \\
\hline Vizisikló (N.atrix navrix) tojás & & & & & & & & \\
\hline B\&ka (Anura spp.) & 18,5 & 16,1 & 15,2 & 6,3 & 2,4 & 11,9 & 12,6 & 3,1 \\
\hline Halak • & 61,6 & 67,6 & 59,7 & 76,2 & 91,4 & $\mathbf{7 3 , 5}$ & 66,7 & 89,2 \\
\hline Gerinde lem ek & 11,5 & 6,8 & 9,4 & 11,9 & 5,9 & 8,7 & 13,1 & 5,2 \\
\hline Siska (A Gioidea spp.) & & & 0,3 & & & & & \\
\hline Kélrfitrinka (Carabus vio laceus) & & & & & & & 0,5 & 0,3 \\
\hline Sárgaszegel yü csik bo girir (Dytiscus ma rginalis) & 9,0 & 3,8 & 0,8 & 8,6 & 4,8 & 6,1 & 9,3 & 3,8 \\
\hline Callkbo gir (Dytiscidae spp.) & & 0,2 & & & & & 0,6 & \\
\hline 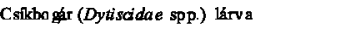 & & & & & & & 0,5 & \\
\hline Pattanóboghr (Elateridae spp.) & & 0,1 & & & & & & \\
\hline Kat icabogát (Coccin ella spp.) & & & 0,3 & & & & & \\
\hline Májusi cserebo gár (Melolontha melolontha) & & & & & & 0,6 & & \\
\hline Gal acsinhujitó bogár (Scarabeidae spp.) & & & & 0,2 & & & & \\
\hline Cincét (Cerambycidae spp.) & & 0,1 & & & & & & \\
\hline Bogár (Coleoptera spp.) & & & & & & 0,3 & 0,6 & \\
\hline Sgitaköto (Odonata spp.) & & 0,3 & & & & & & 0,4 \\
\hline Darazzs (Vespidae spp.) & & & 0,2 & & & & & \\
\hline Rovar (Insecta spp) & 1,7 & 2,2 & 7,3 & 2,3 & 0,3 & 0,6 & & \\
\hline 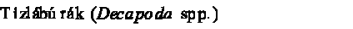 & & & & & & & & 0,4 \\
\hline Kō zōn şges bolharák (Gammanus fassanum ) & & & & & & 0,8 & & \\
\hline Bolharak (Ga mmanus spp.) & 0,1 & 0,1 & & & 0,4 & & & \\
\hline Csikp ol osk a (Naucaris amim id $\sigma$ ) & & & & & & & 0,5 & \\
\hline Karimás tány éresiga (Plan orbis plenorbis) & & & & & & 0,3 & & 0,3 \\
\hline Csiga (Gastropoda spp.) & 0,7 & & 0,5 & 0,8 & 0,4 & & 1,1 & \\
\hline Non vények & 6,4 & 2,9 & $\mathbf{3 , 2}$ & 2,6 & - & 凤,9 & a,5 & - \\
\hline Szeder (Rubus spp.) & & & & & & & 0,5 & \\
\hline Mag & 0,1 & 0,2 & 0,3 & 0,4 & & 0,3 & & \\
\hline Levél & 0,3 & & & & & 0,3 & & \\
\hline P áaitffffélék (Graminaee spp.) & 0,4 & 0,3 & 0,2 & 0,2 & & & & \\
\hline Gyékén yisás (Typha/Carex spp.) & 3,3 & 0,7 & 1,3 & 1,8 & & 0,3 & & \\
\hline BEkalencse (Lemna sp.) & 2,3 & 1,7 & 1,4 & 0,2 & & & & \\
\hline Egy $6 \mathbf{b}$ & & & & & & & & \\
\hline Nylon & & & + & + & & & & \\
\hline Fadarab & + & + & + & & & & & \\
\hline Kavics & & + & & & & & & \\
\hline Mint aszám (n) & 406 & 699 & 396 & 441 & 413 & 391 & 130 & 346 \\
\hline 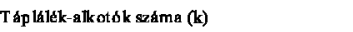 & 702 & 1168 & 631 & 666 & 779 & 592 & 199 & 489 \\
\hline $\mathbf{k} \mathbf{n}$ & 1,7 & 1,7 & 1,6 & 1,5 & 1,9 & 1,5 & 1,5 & 1,4 \\
\hline
\end{tabular}


4. melléklet: A haltáplálék-készlet és a vidra haltáplálék-összetétele az 1-3. vizsgált évben a fonói halastavon

Megjegyzés: "+" - előfordulás 0,5\% alatt, "-" - nem fordult elő a vidra haltáplálékában; B\% - halak biomassza számítás szerinti százalékos megoszlása; E\%. - halfajok százalékos elöfordulási gyakorisága; Súlykat. - halak súlykategóriái: 1 - $50 \mathrm{~g}$ alatt, 2 - 50-100 g, 3 - 100-500 g, 4 - 500-1000 g, 5 - 1000 g felett.

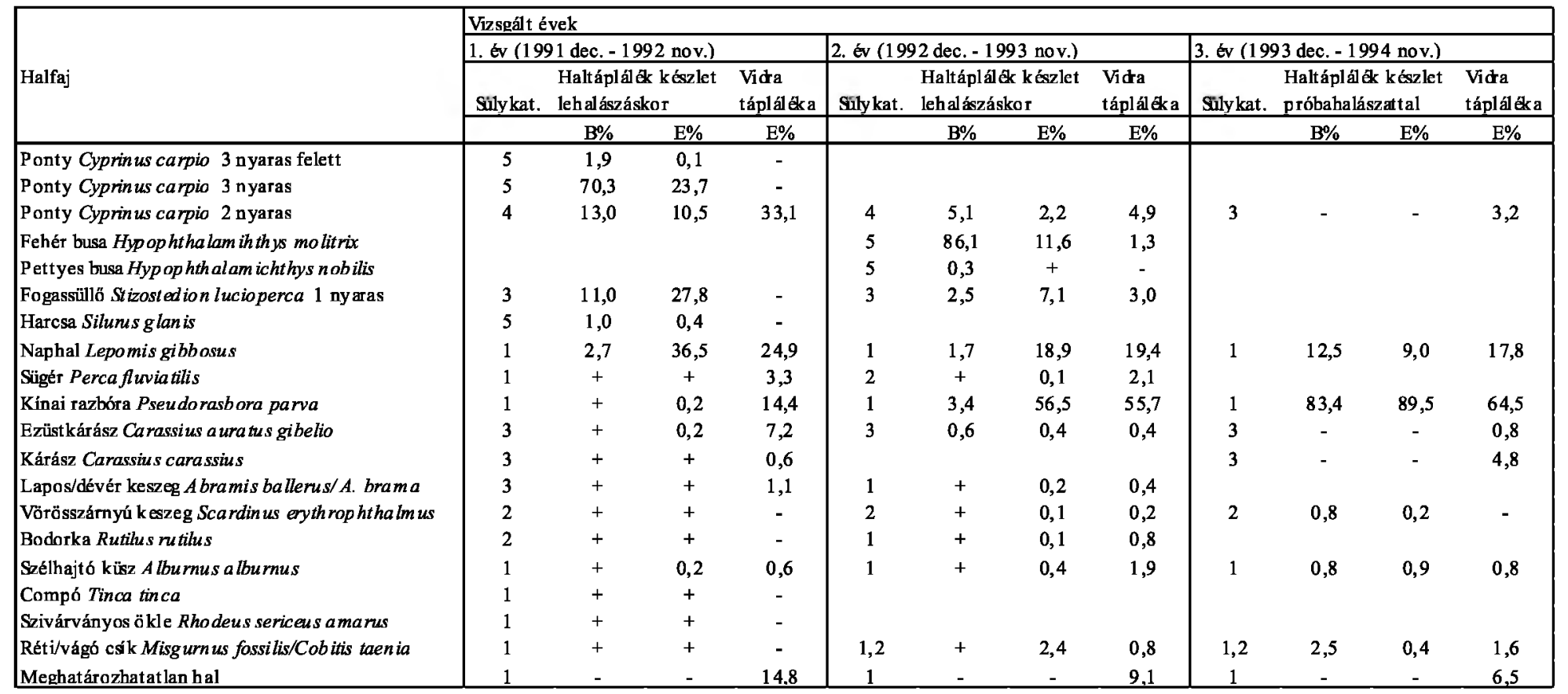


5. melléklet: A haltáplálék-készlet és a vidra haltáplálék-összetétele a 4-6. vizsgált évben a fonói halastavon

Megjegyzés: "+" - előfordulás 0,5\% alatt, "-" - nem fordult elő a vidra haltáplálékában; B\% - halak biomassza számítás szerinti százalékos megoszlása; E\%. - halfajok százalékos előfordulási gyakorisága; Súlykat. - halak súlykat 8 - 50-100 g, 3 - 100-500 g, 4 - 500-1000 g, 5 - $1000 \mathrm{~g}$ felett

\begin{tabular}{|c|c|c|c|c|c|c|c|c|c|c|c|c|}
\hline \multirow{4}{*}{ Halfaj } & \multicolumn{12}{|c|}{ Vizsgált évek } \\
\hline & \multicolumn{4}{|c|}{ 4. év (1994 dec. -1995 nov.) } & \multicolumn{4}{|c|}{ 5. év (1995 dec. - 1996 nov.) } & \multicolumn{4}{|c|}{ 6. év (1996 dec. - 1997 nov.) } \\
\hline & \multirow[t]{2}{*}{ Súlykat } & \multicolumn{2}{|c|}{$\begin{array}{l}\text { Haltáp lálék készle } \\
\text { próbahalászattal }\end{array}$} & \multirow{2}{*}{$\begin{array}{l}\begin{array}{l}\text { Vidra } \\
\text { tápláléka }\end{array} \\
\text { E\% }\end{array}$} & \multirow[t]{2}{*}{\begin{tabular}{|l} 
Sülyk at. \\
\end{tabular}} & \multicolumn{2}{|c|}{$\begin{array}{l}\text { Haltáp lálék készlet } \\
\text { leh alászáskor }\end{array}$} & \multirow{2}{*}{$\begin{array}{l}\begin{array}{l}\text { Vidra } \\
\text { táp láléka }\end{array} \\
\text { E\% }\end{array}$} & \multirow[t]{2}{*}{\begin{tabular}{|l} 
Sí yk at. \\
\end{tabular}} & \multicolumn{2}{|c|}{$\begin{array}{l}\text { Haltáp lálék készl et } \\
\text { leh alásđŕsk or }\end{array}$} & \multirow{2}{*}{$\begin{array}{l}\begin{array}{l}\text { Vidra } \\
\text { tápláléka }\end{array} \\
\text { E\% }\end{array}$} \\
\hline & & $\mathrm{B} \%$ & $\mathrm{E} \%$ & & & B\% & $\mathrm{E} \%$ & & & $\mathrm{~B} \%$ & $\mathrm{E} \%$ & \\
\hline Ponty Cyprin us carpio 3 nyaras & & & & & 4 & 0,1 & + & 14,8 & 4 & 0,15 & + & 1,4 \\
\hline Ponty Cyprin us carpio 2 nyaras & & & & & 3 & 35,1 & 43,3 & 1,8 & 3 & 47,2 & 45,1 & 30,7 \\
\hline Fehér busa Hypoph thala michthys molitrix & & & & & 5 & 35,0 & 2,6 & 3,2 & 5 & 35,4 & 2,0 & 0,3 \\
\hline Amúr Ctenopha ringodon idella & & & & & 3 & 17,5 & 6,5 & 4,0 & 3 & 10,0 & 2,9 & 2,8 \\
\hline Fogassüllb Stizostedion lucioperca & & & & & 3 & 0,6 & 0,7 & 0,7 & 3 & 0,05 & + & 0,1 \\
\hline Csuka Esox lucius & & & & & 3 & 0,6 & 0,4 & 7,5 & 3 & 0,1 & + & 0,4 \\
\hline Harcsa Silunus glan is & & & & & 3 & 4,7 & 1,2 & 0,4 & 5 & 0,6 & + & - \\
\hline Naphal Lepomis gibbosus & 1 & 12,5 & 9,0 & 10,9 & 1 & 0,3 & 1,4 & 7,2 & 1 & 0,6 & 2,3 & 3,6 \\
\hline Sügér Perca fluvia tilis & & & & & 1 & + & + & 1,1 & 2 & + & + & 0,1 \\
\hline Kinai razbóra Pseu dorasbora parva & 1 & 83,4 & 89,5 & 52,5 & 1 & 5,6 & 41,2 & 28,2 & 1 & 5,3 & 30,4 & 52,7 \\
\hline Ezüstkátász Ca rassius a ura tus gibelio & 3 & 1,7 & 0,4 & 1,0 & 3 & 0,1 & 0,2 & 12,6 & 3 & 0,2 & 0,3 & 3,1 \\
\hline Lapos-/dévér keszeg Abramis ballerus/A. brama & $1^{*}$ & - & - & 25,7 & 2 & + & + & 2,2 & 2 & + & + & 0,1 \\
\hline Vörösszárnyú keszeg Scardinus erythroph thalm us & 2 & 0,8 & 0,2 & 1,0 & 2 & + & + & 1,4 & 2 & + & + & 0,7 \\
\hline Pontyféle Cyprinidae spp. & & & & & 2 & - & . & 2,9 & 2 & - & - & 1,0 \\
\hline Bodorka Rutilus nutilus & & & & & 1 & + & + & 0,4 & 1 & + & + & . \\
\hline Szélhajtó küsz A lburnus alburnus & 1 & 0,8 & 0,9 & 1,0 & 1 & 0,3 & 2,2 & - & 1 & 0,3 & 16,9 & 0,1 \\
\hline Compó Tinca tinca & & & & & 2 & + & + & - & 3 & + & + & - \\
\hline Szivárványos ökle Rhodeus sericeus a marus & & & & & 1 & + & + & 0,4 & 1 & + & + & - \\
\hline Réti/vágó cśk Misgurn us fossilis/Cobitis ta en ia & 2,1 & 0,8 & + & 1,0 & 1 & + & + & 0,4 & 1 & + & + & - \\
\hline Meghatározhatatlan hal & 1 & - & - & 6,9 & 2 & - & - & 9,0 & 2 & - & - & 2,9 \\
\hline Meghatározhatatlan hal & & & & & 4 & - & - & 1,4 & & & & \\
\hline Meghatározhatatlan hal & & & & & 5 & - & - & 0,4 & & & & \\
\hline
\end{tabular}


6. melléklet: A haltáplálék-készlet és a vidra táplálék-összetétele az 1. és a 2. vizsgált évben a Boronka-melléki Tájvédelmi Körzet Dávodpusztai tavain

Megjegyzés: "+" - elöfordulás 0,5\% alatt, "-" - nem fordult eló a vidra haltáplálékában; B\% - halak biomassza számítás szerinti százalékos megoszlása: E\%. - halfajok százalékos előfordulási gyakorisága; Súlykat. - halak súlykategóriái: 1 - 50 g alatt, 2 - 50-100 g, 3 - 100-500 g, 4 - 500-1000 g, 5 - 1000 g felett.

\begin{tabular}{|c|c|c|c|c|c|c|c|c|}
\hline \multirow{4}{*}{ Halfaj } & \multicolumn{8}{|c|}{ Vizgált évek } \\
\hline & \multicolumn{4}{|c|}{ 1. év (1996 dec. - 1997 nov.) } & \multicolumn{4}{|c|}{ 2. év (1997 dec. - 1998 nov.) } \\
\hline & \multirow[t]{2}{*}{ Sülykat. } & \multicolumn{2}{|c|}{$\begin{array}{l}\text { Haltáplálék készlet } \\
\text { lehalászáskor }\end{array}$} & \multirow{2}{*}{$\begin{array}{l}\begin{array}{l}\text { Vidra } \\
\text { tápláléka }\end{array} \\
\mathrm{E} \% \\
\end{array}$} & \multirow[t]{2}{*}{ Súlykat. } & \multicolumn{2}{|c|}{$\begin{array}{l}\text { Haltáplálék készlet } \\
\text { lehalászáskor }\end{array}$} & \multirow{2}{*}{$\begin{array}{c}\begin{array}{l}\text { Vidra } \\
\text { tápláléka }\end{array} \\
\mathrm{E} \% \\
\end{array}$} \\
\hline & & $\mathrm{B} \%$ & $\mathrm{E} \%$ & & & $\mathrm{~B} \%$ & $\mathrm{E} \%$ & \\
\hline Ponty Cyprinus carpio 3 nyaras felett & 5 & 22,5 & 2,6 & 1,1 & 5 & 62,9 & 12,2 & 1,3 \\
\hline Ponty Cyprinus carpio 3 nyaras & 4 & 0,4 & 0,2 & 1,4 & 4 & 0,7 & 0,6 & 3,2 \\
\hline Ponty Cyprinus carpio 2 nyaras & 3 & 2,6 & 2,2 & 1,2 & 3 & 0,1 & + & 1,3 \\
\hline Amúr Ctenopharingodon idella & & & & & 5 & 6,9 & 1,2 & 1,1 \\
\hline Amúr Ctenopharingodon idella & & & & & 4 & 0,8 & 0,6 & 0,9 \\
\hline Csuka Esox lucius & 5 & 1,5 & 0,1 & - & 5 & 3,7 & 1,9 & - \\
\hline Csuk a Esox lucius & 4 & 21,9 & 9,0 & 1,2 & 4 & 1,7 & 1,2 & 0,4 \\
\hline Csuka Esox lucius & 3 & 2,5 & 1,6 & 4,9 & 3 & 1,7 & 2,9 & 2,8 \\
\hline Naphal Lepom is gibbosus & 1 & + & 0,8 & - & 1 & 0,1 & 2,3 & 5,1 \\
\hline Sügér Perca flu viatilis & 2 & 1,7 & 5,3 & 3,8 & 1 & 2,9 & 42,8 & 4,1 \\
\hline Kínai razbóra Pseudorasbora parva & 1 & + & 1,3 & 20,8 & 1 & 0,1 & 3,4 & 21,1 \\
\hline Ezüstkárász Carassius a ura tus gib elio & 4 & 13,7 & 5,4 & 0,7 & 4 & 9,2 & 6,7 & 1,9 \\
\hline Ezüstkárász Carassius a ura tus gibelio & 3 & 13,7 & 8,7 & 61,9 & 3 & 8,2 & 13,8 & 37,6 \\
\hline Ezüstkárász Ca rassius a ura tus gibelio & 2 & 19,4 & 61,7 & 0,2 & 2 & 0,8 & 8,1 & 3,0 \\
\hline Bodorka Rutilus rutilus & 1 & + & 0,6 & 0,9 & 1 & 0,1 & 1,7 & 6,8 \\
\hline Réti/vágó csík Misg urn us fossilis/ Cobitis taenia & 2 & + & 0,5 & - & 2 & 0,1 & 0,7 & 0,2 \\
\hline Meghatáro zhatatlan hal & 2 & - & - & 0,5 & 1 & - & - & 2,6 \\
\hline Meghatárođłatatlan hal & 3 & - & - & 0,7 & 3 & - & - & 4,9 \\
\hline Meghatáro zhatatlan hal & & & & & 4 & - & - & 0,9 \\
\hline
\end{tabular}


7. melléklet: A vidra téli-tavaszi táplálék-összetétele a Dráva-mentén

\begin{tabular}{|c|c|c|c|c|c|c|c|c|c|c|c|c|c|}
\hline & \multicolumn{13}{|c|}{ Dráva-mente élóhelyei } \\
\hline Táplálék taxon & 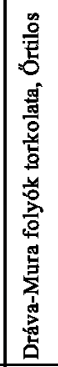 & 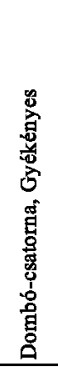 & 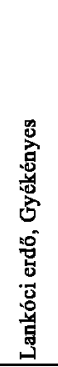 & 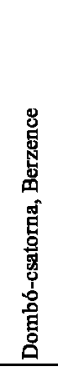 & 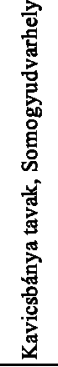 & 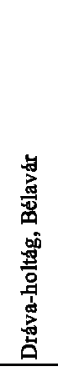 & 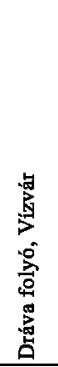 & 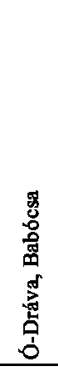 & 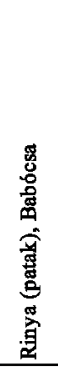 & 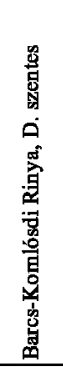 & 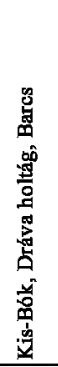 & 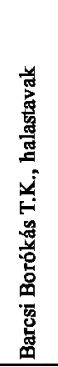 & 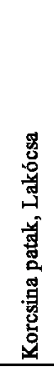 \\
\hline & \multicolumn{13}{|c|}{ Relatív előfordulási gyakoriság, \% } \\
\hline Kis- és kăzepes emlåsäk & 1,1 & 5,9 & 4,8 & 0,9 & 3,3 & 1,4 & 2,7 & - & 6,1 & 15,1 & 2,6 & 1,4 & 1,5 \\
\hline Közönséges vízicickány (Neomys fodiens) & & 0,8 & & & & & & & 3,0 & & & & \\
\hline Cickány (Soricidae spp.) & & & 1,0 & & 3,3 & 0,7 & & & 1,5 & & 1,3 & & 1,5 \\
\hline Közōnséges erdeiegér (Apodemus sylvaticus) & & 0,8 & & & & & & & & & & & \\
\hline Erdeiegér (Apodemus spp.) & & & & & & & 0,9 & & & & 1,3 & & \\
\hline Pézsmapocok (Ondatra zibethicus) & & 0,8 & & & & 0,7 & 0,9 & & & & & & \\
\hline Vizipocok (Arvicola terrestris) & & 0,8 & 3,8 & 0,9 & & & 0,9 & & & 12,1 & & 0,5 & \\
\hline Erdei pocok (Clethrionomys glareolus) & & & & & & & & & & & & & \\
\hline Mezei pocok (Microtus arvalis) & & 0,8 & & & & & & & & & & & \\
\hline Pocok (Microtus spp.) & & & & & & & & & & 3,0 & & & \\
\hline Rágcsáló (Rodentia spp.) & 1,1 & 1,8 & & & & & & & 1,5 & & & 0,9 & \\
\hline Madarak & $\mathbf{7 , 5}$ & 6,8 & 4,8 & 1,7 & - & 1,4 & 8,0 & 1,8 & 4,2 & 9,1 & 1,3 & 4,1 & - \\
\hline Kékcinege (Parus coeruleus) & & & & & & & & & 0,4 & & & & \\
\hline Kenderike (Carduelis spp.) & & & & & & & & & 0,4 & & & & \\
\hline Sármány (Emberiza spp.) & & & & & & & & & & & & 0,2 & \\
\hline Pintyféle (Fringillidae spp.) & & & & & & & 0,9 & & & & & & \\
\hline Kistestủ énekesmadár (Passeriformes spp.) & 7,5 & 6,8 & 3,8 & 0,8 & & 1,4 & 4,4 & 1,0 & 2,3 & 9,1 & 1,3 & 1,4 & \\
\hline Jégmadár ( Alcedo atthis) & & & & & & & 0,9 & & 0,8 & & & & \\
\hline Énekes rigd (Turdus philomelos) & & & & 0,9 & & & & & & & & & \\
\hline Fácán (Phasianus colchicus) & & & & & & & & & & & & 0,3 & \\
\hline Vuzityúk (Gallinula chloropus) & & & & & & & & & & & & & \\
\hline Réce $($ Anas spp.) & & & & & & & & 0,4 & & & & 1,4 & \\
\hline Szárcsa (Fulica atra) & & & & & & & & & & & & & \\
\hline Guvat (Rallus aquaticus) & & & & & & & & 0,4 & & & & & \\
\hline Közepes test lí vízimadár & & & & & & & 1,8 & & 0,4 & & & 0,5 & \\
\hline Tojás & & & 1,0 & & & & & & & & & 0,3 & \\
\hline Hüllåk+kétéltuñ ek & 12,9 & 23,7 & 25,7 & 15,5 & 10,0 & 9,7 & 8,9 & 2,5 & 22,1 & 24,2 & 5,1 & 10,0 & 23,6 \\
\hline Rézsikló (Coronella austriaca) & & & & & & & & & & & & & \\
\hline Vizisikló (Natrix natrix) & & 0,8 & 2,9 & & & 0,7 & 0,9 & & & & & 1,7 & 2,9 \\
\hline Siklófélék (Colubridae spp.) & & & & & & & & & & 3,0 & & & \\
\hline S'kló félék (Colubridae spp.) tojása & & & & & & & & & & & & & \\
\hline Barna varangy (Bufo bufo) & 1,1 & & & 0,9 & 5,0 & 2,1 & & & 1,1 & & & 1,1 & \\
\hline Kecskebéka (Rana esculenta) & 2,2 & & & 5,2 & & 1,4 & 2,7 & & 4,2 & & 1,3 & 2,0 & 5,9 \\
\hline T avi-/kecskebéka (Rana spp.) & & & & & & & & & & & & 0,5 & \\
\hline Barna ásóbéka (Pelobates fuscus) & 1,1 & & & & & & 0,9 & & & & & & 1,5 \\
\hline Zōld levelibéka (Hyla arborea) & & & & & & & & 0,4 & 0,4 & & & 0,3 & 1,5 \\
\hline Unka (Bombina spp.) & & & & & & & & & & & & 0,2 & \\
\hline Béka (Anura spp.) & 8,5 & 22,9 & 22,8 & 9,4 & 5,0 & 5,5 & 4,4 & 2,1 & 16,3 & 21,2 & 3,8 & 4,2 & 11,8 \\
\hline Halak & 71,0 & 54,2 & 42,9 & 74,1 & 81,7 & 79,2 & 64,6 & 89,4 & 45,2 & 15,2 & 75,7 & 64,9 & 30,8 \\
\hline Tokféle (Acipenseridae spp.) & & & & & & 0,7 & & & & & & & \\
\hline Ponty (Cyprinus carpio) & 2,2 & & & & & 0,7 & 1,8 & & 1,9 & & 1,3 & & \\
\hline Eziïstkárász (Carassius auratus gibelio) & 11,7 & 12,8 & 3,8 & & 20,0 & 3,5 & 2,7 & 37,5 & 13,6 & & 9,0 & 22,7 & 4,4 \\
\hline Kárász (Carassius carassius) & 4,3 & 0,8 & & & 3,3 & & 1,8 & 0,7 & 1,1 & & 2,6 & 12,6 & \\
\hline Kárász (Carassius spp.) & 3,2 & & & & & 3,5 & 1,8 & & 1,9 & & 1,3 & 4,8 & \\
\hline
\end{tabular}




\section{7. melléklet: folytatása}

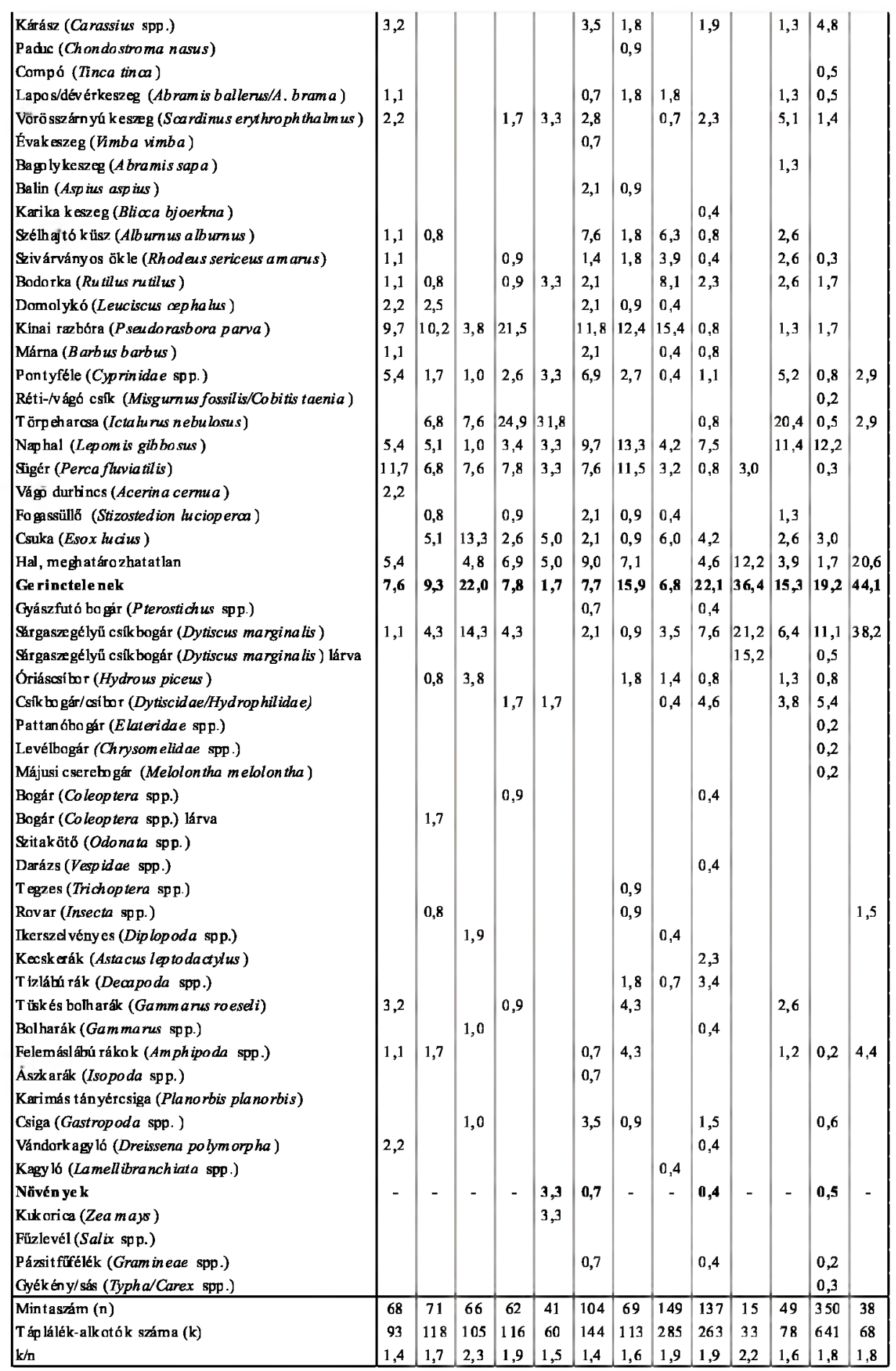


8. melléklet: A vidra nyári-őszi táplálék-összetétele a Dráva-mentén

\begin{tabular}{|c|c|c|c|c|c|c|c|c|c|c|c|c|c|}
\hline \multirow{3}{*}{ Táplálék taxon } & \multicolumn{13}{|c|}{ Dráva-mente élöhelyei } \\
\hline & 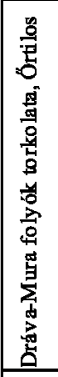 & 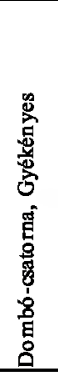 & 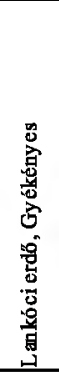 & 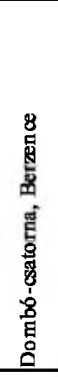 & 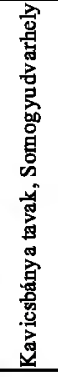 & 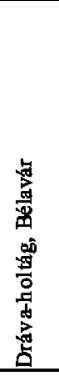 & 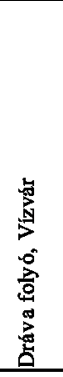 & 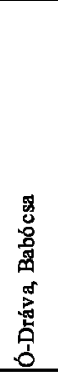 & 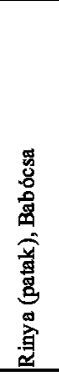 & 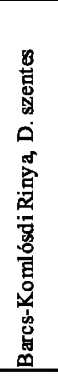 & 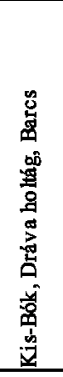 & 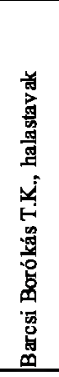 & 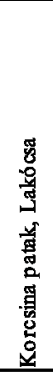 \\
\hline & \multicolumn{13}{|c|}{ Relatív előfordulás i gyakoris ág, \% } \\
\hline Kis- és közepes e mlósök & $\mathbf{0}, \mathbf{8}$ & $\mathbf{5 , 5}$ & 9,2 & 7,6 & 4,0 & $\mathbf{2 , 1}$ & 6,0 & 0,5 & 6,7 & - & - & 0,4 & 2,3 \\
\hline Kö n̈ nséges víxicickány (Neomysfodiens) & & & 3,1 & & & & & & & & & & \\
\hline Vizicickány (Neomys spp.) & & & & 1,7 & & & & & & & & & \\
\hline Cickány (Soricidae spp.) & & 1,4 & & & & & 6,0 & & & & & & \\
\hline Kö zö nséges erdeiegér (A po dem us sylva ticus) & & & & & & & & & 0,7 & & & 0,2 & \\
\hline Ván dorpatk án y (Rat tus norvegicus) & & & & & & & & & 0,7 & & & & \\
\hline Pézsmapocok (Ondatra zibethicus) & 0,8 & 2,0 & & & & 1,1 & & & 0,3 & & & & 0,8 \\
\hline Vizipocok (Arvicola terrestris) & & & 4,6 & 0,8 & & & & & 3,0 & & & & 1,5 \\
\hline Erdei pocok (Clethrionomys glareolus) & & 0,7 & 1,5 & & & & & & 0,3 & & & 0,2 & \\
\hline Mezei pocok (Microtus a nalis) & & 0,7 & & 1,7 & 4,0 & 0,5 & & & 0,7 & & & & \\
\hline Rágcsáló (Rodentia spp.) & & 0,7 & & & & 0,5 & & 0,5 & 1,0 & & & & \\
\hline Madarak & 4,0 & 3,4 & 3,1 & 2,5 & - & 2,7 & 12,0 & 0,5 & 2,2 & - & 2,6 & 3,4 & - \\
\hline Kékcin ege (Parus coenuleus) & & & & & & & & & 0,3 & & & & \\
\hline Kistestü ének esmadár (Passeriformes spp.) & 3,2 & 2,1 & 1,6 & 2,5 & & 1,6 & 8,0 & & 1,6 & & 2,6 & 2,0 & \\
\hline Énekes rigó (Turdus philom elos) & 0,8 & & & & & & & & & & & & \\
\hline Fácán (Phasianus colchicus) & & & & & & 0,5 & & & & & & & \\
\hline Réce $(A n a$ & & & & & & & & 0,5 & & & & 0,2 & \\
\hline S7.árcsa (Fulica atra) & & & & & & & & & & & & 0,2 & \\
\hline Kö zepes testlł vízimadár & & 1,3 & 1,5 & & & 0,5 & 4,0 & & 0,3 & & & 1,0 & \\
\hline HũlId k+k été ltffek & 11,2 & 28,1 & 13,8 & 10,2 & 28,0 & 15,6 & 14,0 & 13,6 & 8,9 & 2,6 & 15,4 & 13,2 & 22,3 \\
\hline Rézsik ló (Coronella austriaca) & 0,8 & & & & 4,0 & & & & & & & & \\
\hline Vizisikló (Natrix natrix) & & 2,1 & & 1,7 & & & & 1,0 & & & 7,7 & & \\
\hline Sik lófélék (Colubridae spp.) & 0,8 & & & & 4,0 & 1,6 & & 1,0 & & & & 1,4 & 4,6 \\
\hline Gy ik (Sa uria spp.) & & 0,7 & & & & 0,5 & & & & & & & \\
\hline Hüllō (Reptilia spp.) & & & & & & & & & & & & 0,2 & \\
\hline Bama varangy (Bufo bufo) & & & & & & 0,5 & & & & & & & \\
\hline Kecskebck a (Ra na esculenta) & 1,6 & & & & 4,0 & 1,1 & & 2,0 & 1,0 & & & 1,6 & 2,3 \\
\hline Tavi-kecskebéka (Rana spp.) & 0,8 & 1,4 & 3,1 & 0,8 & & 1,1 & 2,0 & 1,0 & 0,7 & & 2,6 & & 0,8 \\
\hline Barna ásó beka (Pelo ba tes fuscus) & & & & 0,8 & 4,0 & 1,1 & & 0,5 & & & & & 0,8 \\
\hline Zöld levelibék a (Hyla arborea) & & & & & & & & 0,5 & & & & 1,0 & \\
\hline Unka (Bombina sp p.) & & 0,7 & & & & & & & & & & & \\
\hline Béka (Anura spp.) & 7,2 & 23,2 & 10,8 & 6,8 & 12,0 & 9,7 & 12,0 & 7,6 & 7,2 & 2,6 & 5,1 & 8,9 & 13,8 \\
\hline Halak & 78,4 & 37,7 & 50,8 & 63,6 & 48,0 & 62,4 & 50,0 & 75,8 & 58,7 & 90,7 & 64,1 & 65,1 & 32,3 \\
\hline Ponty (Cyprinus carpio) & 4,8 & & & & & 1,1 & & 3,0 & 1,6 & & & & \\
\hline Ezüst kárász (Carassius auratus gibelio) & 5,6 & 1,4 & 1,5 & 6,8 & 8,0 & 10,8 & 8,0 & 36,9 & 19,9 & 3,3 & 5,1 & 39,0 & 6,8 \\
\hline Kárász (Carassius cara ssius) & 1,6 & 0,7 & 1,5 & 0,8 & & 1,6 & & 0,5 & 0,7 & & & 2,6 & \\
\hline Kárász (Carassius spp.) & & & & 2,5 & 4,0 & 0,5 & & & 4,6 & & 2,6 & 4,5 & 0,8 \\
\hline Compó (Tinca tinca) & & & & & & & & 0,5 & & & & 0,2 & \\
\hline Lap os/dévérkeszeg ( Abramis ballerus/A. brama) & 0,8 & & & & & & 2,0 & 1,0 & 0,3 & & & 0,4 & \\
\hline $\begin{array}{l}\text { Vörösszárny ú keszeg (Scardin us } \\
\text { erythro ph th alm us) }\end{array}$ & 0,8 & & & 5,9 & & & & & 4,6 & & & 0,8 & \\
\hline Ralin (A spius a spius) & & & & & & & & & 1,0 & & & & \\
\hline Szél hajtó küsz (Albu rnus albu mus) & 13,6 & 4,1 & & 1,7 & 4,0 & 3,2 & 2,0 & 2,0 & 0,3 & & 5,1 & & 0,8 \\
\hline Szivárván yos ökle (R hodeus sericeus amarus) & 2,4 & & & 1,7 & & 2,7 & 2,0 & 6,6 & 2,0 & & 2,6 & 0,4 & \\
\hline Bo dork a (Rutilus nutilus) & 4,8 & 0,7 & 3,1 & & & 1,6 & & 2,0 & 2,0 & 0,5 & & 0,8 & \\
\hline Domolykó (Leuciscus cephahus) & 1,6 & & & & & & & & 0,3 & & & & \\
\hline Kinai razbóra (Pseudorasbora pana) & 1,6 & 2,1 & & 4,2 & & & & 9,2 & 0,7 & 85,3 & & 3,0 & \\
\hline
\end{tabular}


8. melléklet: folytatása

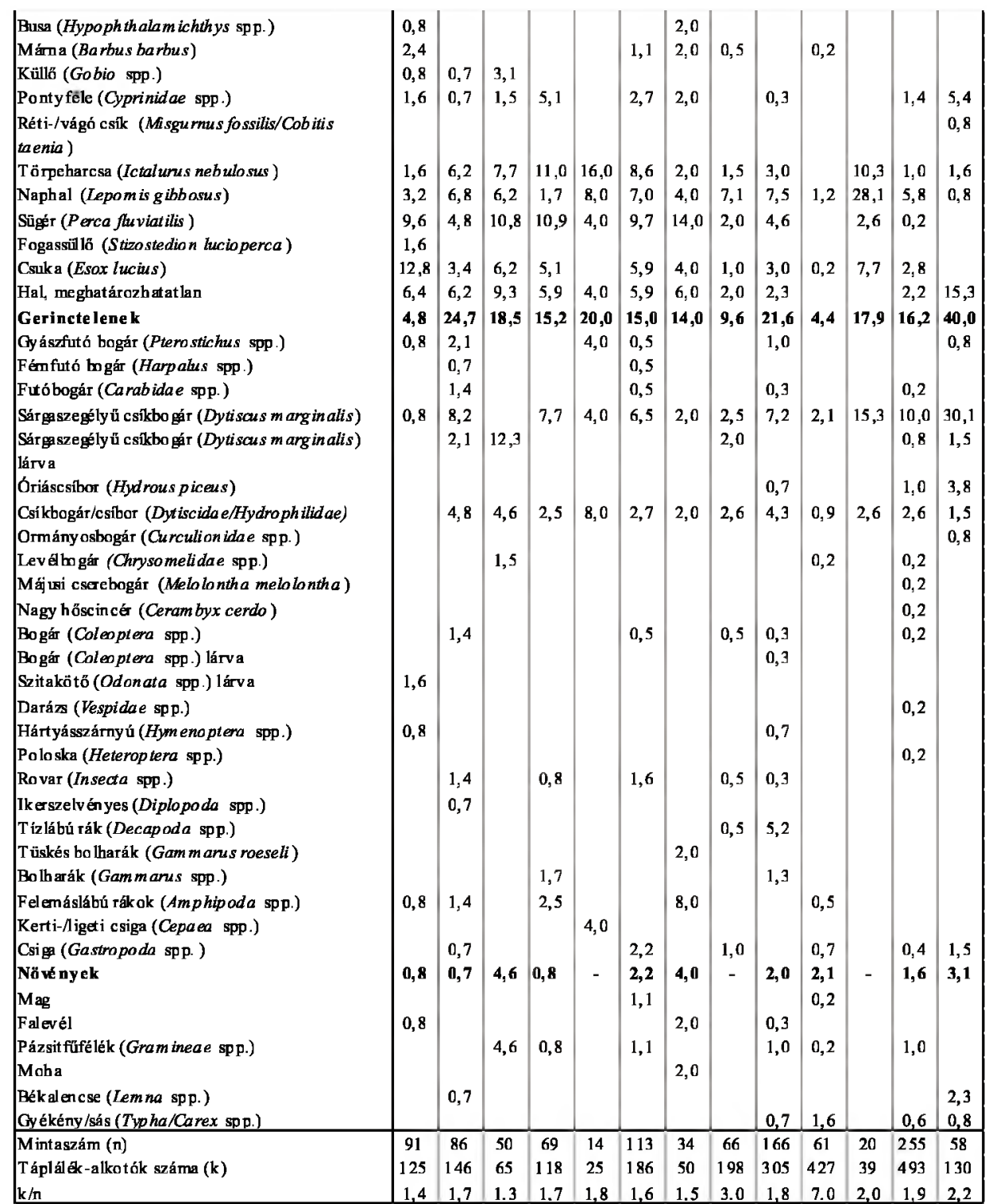


9. melléklet: A vidra táplálék-összetétele relatív előfordulási gyakoriság és biomassza számítás alapján

Jelmagyarázat: E\% =relatív előfordulási gyakoriság, \%; B\% = biomassza számítás szerinti összetétel, \%; + = előfordulás 0,5\% alatt

\begin{tabular}{|c|c|c|c|c|c|c|c|c|c|c|c|c|c|c|c|c|c|c|c|c|}
\hline \multirow{3}{*}{ Táplálék taxon } & \multicolumn{8}{|c|}{ Mike-Petesmal om, halastav ak (1997-1998) } & \multicolumn{8}{|c|}{ Gyékényes, Lankóci erd̋́ (2000-2001) } & \multicolumn{4}{|c|}{ Látrány, Tetves patak (2001 } \\
\hline & \multicolumn{2}{|c|}{ Tél } & \multicolumn{2}{|c|}{ Tavasz } & \multicolumn{2}{|c|}{ Nyár } & \multicolumn{2}{|l|}{$\delta_{\mathrm{sz} z}$} & \multicolumn{2}{|c|}{ Tél } & \multicolumn{2}{|c|}{ Tavasz } & \multirow{2}{*}{\multicolumn{2}{|c|}{$\begin{array}{l}\text { Ny ár } \\
\text { E\% | } \\
\text { B\% }\end{array}$}} & \multicolumn{2}{|l|}{ Ósz } & \multirow{2}{*}{\multicolumn{2}{|c|}{ Nyár }} & \multicolumn{2}{|c|}{$\mathrm{Osz}_{\mathrm{sz}}$} \\
\hline & \begin{tabular}{|l|l|}
$\mathrm{E} \%$ & $\mathrm{~B}$ \\
\end{tabular} & $B \%$ & $\mathrm{E} \%$ & $8 \%$ & $\mathrm{E} \%$ & B\% & $\mathrm{E} \%$ & $\mathbf{B} \%$ & E\% & $\mathrm{B} \%$ & $\mathrm{E} \%$ & $18 \%$ & & & $\mathrm{E} \%$ & $1 \mathrm{~B} \%$ & & & $\mathrm{E} \%$ & $\mathbf{B} \%$ \\
\hline Kisem lősök & $0,4 \quad 0$, & 0,2 & 0,8 & 0,4 & - & - & 1,0 & 1,4 & - & - & 7,7 & 4,5 & 3,3 & 4,3 & 14,3 & 7,3 & 1,3 & + & 12,3 & 6,9 \\
\hline Közönséges vízicick ány (Neom ys fodiens) & & & & & & & & & & & & & 3,3 & 4,3 & 2,9 & 0,4 & & & & \\
\hline Cickány (Soricidae spp.) & & & & & & & & & & & 1,5 & 1,0 & & & & & & & & \\
\hline Erdei pocok (Cethrion omys glareolus) & & & 0,2 & 0,3 & & & & 1,4 & & & & & & & 2,9 & 1,0 & & & & \\
\hline Mezei pocok (Microtus arvalis) & 0,30, & 0,1 & & & & & & & & & 6,2 & 3,5 & & & 8,5 & 5,9 & & & & \\
\hline Csalitjáró pocok (Microt us agrestis) & 0,1 & 0,1 & & & & & & & & & & & & & & & & & & \\
\hline Pocok (Microtus spp.) & & & 0,3 & + & & & & & & & & & & & & & 1,3 & + & & \\
\hline Vizipocok (Arvicola terrestris) & & & 0,3 & 0,1 & & & & & & & & & & & & & & & 12,3 & 6,9 \\
\hline Csülkös vad & 0,3 & + & 0,5 & + & - & - & - & - & - & - & - & - & - & - & - & - & - & - & - & \\
\hline Vaddisznó (Sus scrofa) & 0,1 & + & & & & & & & & & & & & & & & & & & \\
\hline Gïmszarvas (Cervus elaphus) & 0,2 & + & 0,2 & + & & & & & & & & & & & & & & & & \\
\hline Óz (Capreolus capreolus) & & & 0,3 & + & & & & & & & & & & & & & & & & \\
\hline Madarak & $\mathbf{0 , 4}$ & + & 0,8 & 0,3 & 3,6 & $\mathbf{0 , 2}$ & - & - & - & - & $\mathbf{7 , 7}$ & 4,6 & $\mathbf{3 , 3}$ & 0,7 & 2,9 & 2,8 & 0,6 & $\mathbf{0 , 1}$ & - & - \\
\hline Kistest ti Énekesnađär (Passeriformes spp.) & 0,4 & + & 0,5 & + & 3,6 & 0,2 & & & & & 6,2 & 4,5 & 3,3 & 0,7 & & & 0,6 & 0,1 & & \\
\hline Közepes test $\mathbf{i}$ madăr & & & 0,3 & 0,3 & & & & & & & & & & & 2,9 & 2,8 & & & & \\
\hline $\begin{array}{l}\text { Tojás } \\
\text { Hüllbk + kété ltứe k }\end{array}$ & 1,5 & 0,7 & & & 7,3 & 2,6 & 3,0 & $\mathbf{2 , 7}$ & 17,1 & 5,8 & \begin{tabular}{|l|l}
1,5 \\
30,8
\end{tabular} & $\begin{array}{c}\mathbf{0 , 1} \\
\mathbf{3 9 , 7}\end{array}$ & 16,7 & $7 \quad$ 19,0 & & 16,5 & 19,5 & 21,4 & $\mathbf{3 7 , 0}$ & 60,4 \\
\hline Mocsári teknós (Emys orbicula ris) & דa & & | & 4,9 & 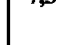 & 2,6 & | & 2,8 & 10 & , & Jow & & 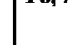 & 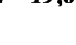 & $\mathrm{Fin}$ & 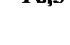 & 1,9 & 2,1 & , & 0,7 \\
\hline Vizisik16 (Natrix natrix) & & & & & & & & & & & 4,6 & 3,9 & & & & & 0,6 & 0,5 & & \\
\hline Siklófélék (Colubridae sp p.) & & & 0,3 & 0,1 & 1,8 & 1,5 & & & & & & & & & & & 0,6 & 3,6 & & \\
\hline $\begin{array}{l}\text { Gy ik (Sauria spp.) } \\
\text { Hülll, (Reptilia spp.) }\end{array}$ & 0,1 & + & 0,3 & 0,1 & & & & & & & & & & & & & & 0,3 & & \\
\hline $\begin{array}{l}\text { Hülll' (Reptilia spp.) } \\
\text { Zöld levelibéka (Hyla a rborea) }\end{array}$ & 0,1 & + & 0,3 & 0,1 & & & & & & & & & & & & & 0,6 & 0,3 & & \\
\hline Barna varangy ( $B$ ufo bufo) & & & 0,5 & 0,7 & & & & 0,3 & & & & & & & & & 3,3 & 4,8 & 4,1 & 21,3 \\
\hline Keoskebéka (Ran a esculenta) & 0,4 & 0,3 & 2,1 & 1,6 & & & & & & & & & & & & & 1,3 & 3,8 & 1,4 & 4,0 \\
\hline Tavi-/kecskebéka (Rana sp p.) & & & 0,5 & 0,6 & & & & & & & & & 6,7 & 9,6 & & & 1,3 & 0,4 & & \\
\hline Béka (Anura spp.) & 0,9 & 0,3 & 4,0 & 1,7 & 5,5 & 1,2 & 2,0 & 2,4 & 17,1 & 5,8 & 26,2 & 35,8 & 10,0 & $0 \quad 9,4$ & 11,4 & 16,5 & 9,8 & 5,9 & 31,5 & 35,1 \\
\hline Halak & $94,2 \quad 98$ & 98,9 & 84,0 & 94,1 & 80,0 & 96,8 & 88,9 & 95,8 & 65,9 & 93,3 & 29,2 & 46,6 & 50,0 & o 73,9 & 51,5 & 72,0 & 20,1 & 16,7 & 20,6 & 22,8 \\
\hline Ponty (Cyprinus carpio) & 7,0 & 9,2 & 21,5 & 31,1 & 5,5 & 6,0 & 17,2 & 22,6 & & & & & & & & & & & 1,4 & 3,9 \\
\hline Ezüst kärász (Cara ssius auratus gibelio) & $50,4 \quad 58$ & 58,1 & 19,6 & 24,3 & 5,5 & 3,0 & 12,1 & 22,8 & & & 6,1 & 14,2 & 3,3 & 1,5 & & & 1,3 & 1,6 & & \\
\hline Kárász (Carassius ca rassius ) & $0,9 \quad 1$, & 1,3 & 0,8 & 0,9 & & & & & & & & & & & 2,9 & 3,1 & & & & \\
\hline Kárász (Carassius spp.) & 5,3 & 6,0 & 3,4 & 3,0 & 9,1 & 4,5 & 12,1 & 13,5 & & & & & & & & & & & & \\
\hline Lapos/dévérkeszeg (Abram is ballerus/A. brama) & 0,1 & 0,1 & & & & & & & & & & & & & & & & & 2,7 & 3,1 \\
\hline Vö rösszárnyú keszeg ( $S$ card inus erythroph thalm us) & 1,6 & 1,1 & & & & & 1,0 & 0,6 & & & & & & & & & & & & \\
\hline Karika keszeg (Blicca bjoerkna) & 0,2 & 0,2 & & & 1,8 & 3,1 & & & & & & & & & & & & & & \\
\hline
\end{tabular}




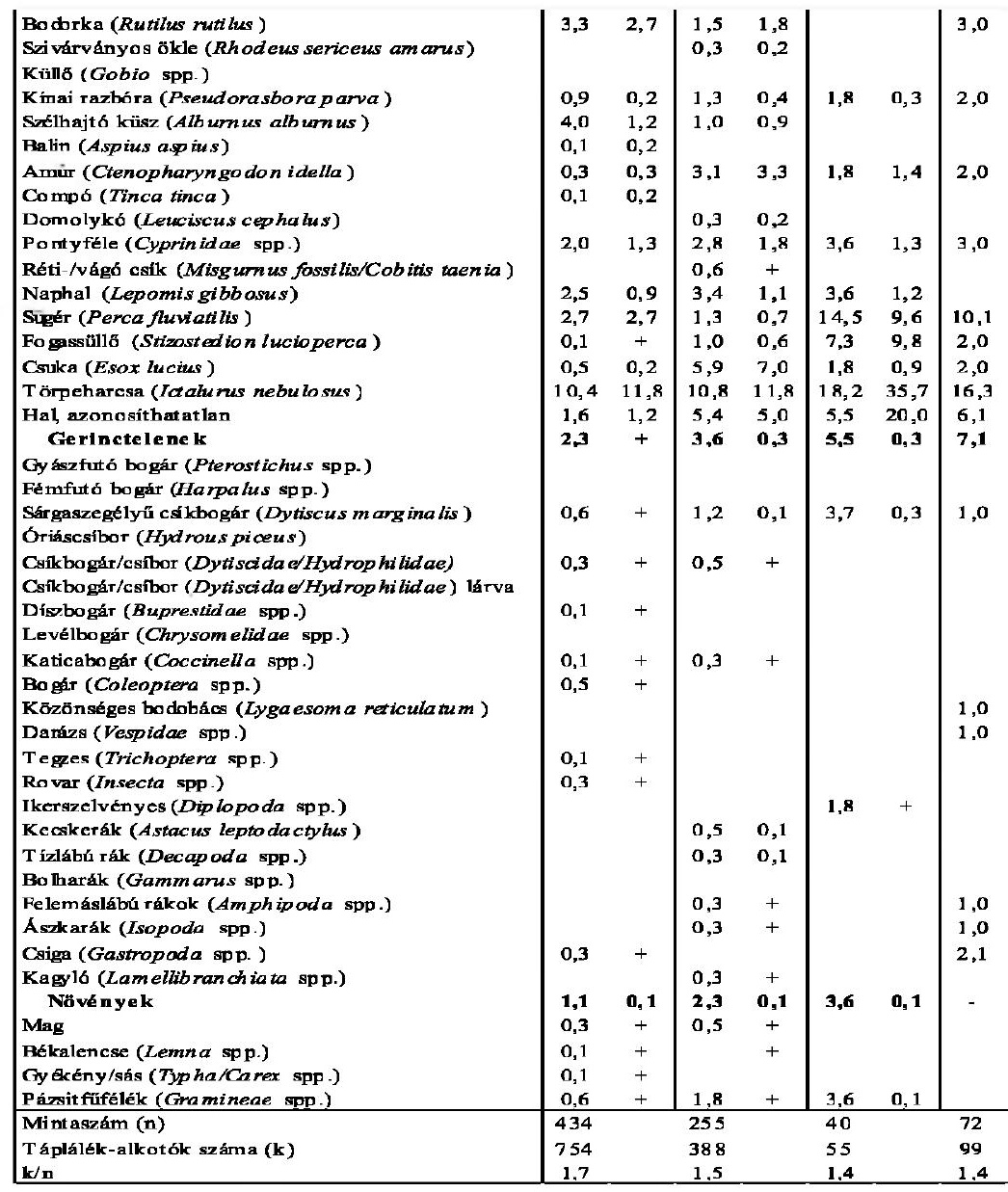




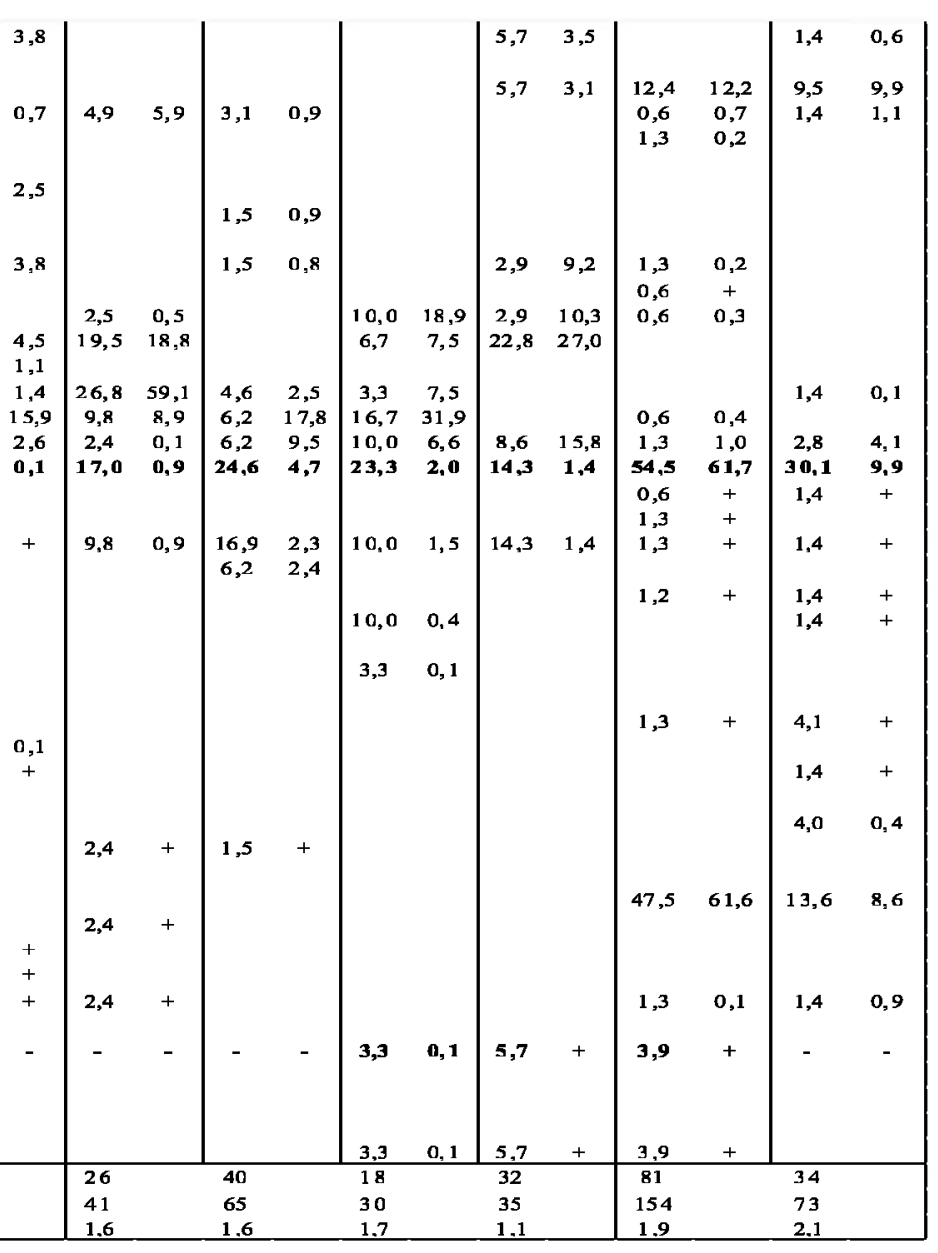


10. melléklet: A hermelin évszakonkénti táplálék-összetétele mezőgazdasági és erdei élöhelyen

Jelmagyarázat: E\%= relatív előfordulási gyakoriság, \%; B\%= biomassza számítás szerinti összetétel \%-a

\begin{tabular}{|c|c|c|c|c|c|c|c|}
\hline \multirow{3}{*}{ Táplálé k ta xon } & \multicolumn{3}{|c|}{ Fonói halastó kărze te (1991-199 } & \multicolumn{4}{|c|}{ Lankóci erdh́ (Gyé ké nyes) (2000-2001) } \\
\hline & Tél & Tavasz & Nyár- $\boldsymbol{C}_{\mathrm{sz}}$ & Té 1-tava & & |Nyár-6́s & \\
\hline & \multicolumn{3}{|c|}{ Elo fordulási gyak oriság. \% } & $\mathbf{E} \%$ & $\mathrm{~B} \%$ & E\% & $\mathrm{B} \%$ \\
\hline KIs- és kãzepes em lơsäk & 70,6 & 54,5 & 46,2 & 81,3 & 99,8 & 56,6 & 76,8 \\
\hline Vakond (Talpa europaea) & & & 3,8 & & & & \\
\hline Mezei ickány (Crocidura leucodon) & & 1,8 & & & & & \\
\hline Cickány (Soricidae spp.) & & 1,8 & & 6,3 & 10,0 & & \\
\hline Mogyorós pele (Muscardin us avellanarius) & & & 5,8 & & & & \\
\hline Kö 7ôn séges erdei egér (Apodem us & & & & & & 4,3 & 11,9 \\
\hline sylvaticus ) & 2,9 & & & & & & \\
\hline Sárgan yakú erdeiegér (Apodemus & & & & 18,8 & 19,1 & & \\
\hline flavicollis ) & 23,5 & 5,5 & 3,8 & & & & \\
\hline Erdeiegér (Apodem us spp.) & 5,9 & 3,6 & & & & & \\
\hline Törpeegé (Micromys minutus) & & & & 6,3 & 10,0 & & \\
\hline Vízipocok (Arvicola terrestris) & 5,9 & & 3,8 & & & 4,3 & 3,8 \\
\hline Erdei poonk (Clethrionomys glareolus) & 5,9 & 5,5 & 1,9 & 12,5 & 14,0 & 17,5 & 21,9 \\
\hline Mezi pocok (Microt us arvalis) & 14,7 & 29,0 & 5,8 & 37,4 & 46,7 & 30,5 & 39,2 \\
\hline Pocok (Microtus spp.) & 8,9 & 1,8 & 9,7 & & & & \\
\hline Rágc sáló (Rodentia spp.) & & 5,5 & 11,5 & & & & \\
\hline Mezi nyú (Lepus europaeus) & 2,9 & & & & & & \\
\hline Madarak & 26,5 & 36,4 & 19,2 & - & - & 21,7 & $\mathbf{2 1}, \mathbf{0}$ \\
\hline Kistestli énekesmadár (Passeriformes sp p.) & 23,6 & 30,9 & 19,2 & & & 17,4 & 7,0 \\
\hline Cinege (Pans spp.) & 2,9 & & & & & & \\
\hline T ajás & & 5,5 & & & & 4,3 & 14,0 \\
\hline Hũllók k+kété ltũe $k$ & - & - & 1,9 & - & - & - & - \\
\hline Vúzisik lo (Natrix natrix ) & & & 1,9 & & & & \\
\hline Ge rin cte len ek & 2,9 & 9,1 & 23,1 & 18,7 & 0,2 & 17,4 & 0,6 \\
\hline Aranypettyes futrinka (Carabus horten sis) & 2,9 & & & & & & \\
\hline Kék futrinka (Carabus vio laceus) & & 1,8 & & & & & \\
\hline Bớrfutrinka (Carab us coriaceus) & & & & & & 4,3 & 0,2 \\
\hline Cserebogár (Melolon tha spp.) & & 1,8 & & & & & \\
\hline Bogár (Coleoptera spp.) & & & & 6,3 & 0,1 & & \\
\hline Darázs (Vespidae spp.) & & 1,8 & & 12,4 & 0,1 & 8,6 & 0,3 \\
\hline Hárty ásszárnyú (Hym enoptera spp.) & & & 1,9 & & & & \\
\hline Rovar (Insecta spp.) & & 3,7 & 21,2 & & & 4,3 & 0,1 \\
\hline Nōvények & - & - & 9,6 & - & - & 4,3 & 1,6 \\
\hline Szamóca (Fragaria spp.) & & & 1,9 & & & & \\
\hline Szedr (Rubus spp.) & & & & & & 4,3 & 1,6 \\
\hline Gyümölcs, meghatározhatatlan & & & 1,9 & & & & \\
\hline Búza (Triticum aestivum) & & & 3,8 & & & & \\
\hline Borost yán mag (Hedera helix) & & & 1,9 & & & & \\
\hline Mintaszám (n) & 28 & 41 & 30 & 14 & & 16 & \\
\hline T áp lálék-alk otók száma (k) & 34 & 55 & 52 & 16 & & 23 & \\
\hline $\mathrm{k} / \mathrm{n}$ & 1,2 & 1,3 & 1,7 & 1,1 & & 1,4 & \\
\hline
\end{tabular}


11. melléklet: A nyest évszakonkénti táplálék-összetétele mezőgazdasági és urbánus környezetben

Jelmagyarázat: $\mathrm{E} \%=$ relatív elófordulási gyakoriság, \%; B\%= biomassza számítás szerinti összetétel, \%; + = elófordulás $0,5 \%$ alatt; *emészthetetlen anyagok nélkül.

\begin{tabular}{|c|c|c|c|c|c|c|c|}
\hline \multirow{3}{*}{ Táplálélék tax an } & \multicolumn{5}{|c|}{$\begin{array}{l}\text { Fonói halastó kōrzete } \\
\text { 1991-1997 }\end{array}$} & \multirow{2}{*}{\multicolumn{2}{|c|}{\begin{tabular}{|l|}
$\begin{array}{l}\text { Fon di malom, } \\
\text { helterület, } 1998\end{array}$ \\
Éves \\
\end{tabular}}} \\
\hline & TEI & Thuag & Nydir & $\tilde{\mathbf{O}} \mathrm{sz}$ & Fives & & \\
\hline & \multicolumn{5}{|c|}{ Relatív előfordulási gyakoriság. \% } & E\% & $\mathrm{B} \%$ \\
\hline KGs - és k äz epes e mlă sāk & 40,3 & 34,5 & 19,1 & 36,5 & 29,9 & 15,5 & 28,1 \\
\hline Közö nsćges törpedenevér (Pipistrellus pipistrellus) & 0,5 & & & & 0,1 & & \\
\hline Vakond (Talpa europaea) & & 0,9 & & & 0,2 & & \\
\hline Mezei cickány (Crocidura leacodon) & & & 0,2 & & 0,1 & & \\
\hline Cick hny (Saricidae spp.) & & 2,7 & & 0,4 & 0,6 & 0,2 & 0,3 \\
\hline Mólous (Sciurus urlgaris) & & & 0,6 & 0,4 & 0,3 & & \\
\hline Nagy pele (Myorus glis) & & & 0,2 & & 0,1 & 0,2 & 1,2 \\
\hline Mogyorós pele (Musondinus avellanarius) & & 1,3 & 1,5 & & 0,9 & & \\
\hline Közö nséges erdeiegŕ (Apodemus sylvauicus) & & & & & & 1,1 & 1,4 \\
\hline Śrágany akćí erdeiegér (Apodem us flavioo lis) & 1,9 & 3,1 & 2,5 & 1,6 & 2,3 & 0,4 & 0,3 \\
\hline Pirókegér (Apodem us agrarius) & & & 0,2 & & 0,1 & 0,2 & 0,4 \\
\hline Erdeiegr (Apademus spp.) & 8,1 & 6,2 & 1,5 & 5,3 & 4,4 & 1,3 & 1,4 \\
\hline Vándorpatkány (Rattus norvegicus) & 0,5 & 1,3 & & 0,8 & 0,5 & 1,1 & 1,9 \\
\hline Házi egér (Mus muscuhus) & 0,9 & 0,9 & 1,5 & 1,2 & 1,2 & 5,8 & 12,2 \\
\hline Pézsmap ocok (Ondatra zibethicus) & 0,9 & 1,3 & 0,2 & & 0,5 & & \\
\hline Vizip ocok (A rvicola terrestris) & & & & & & 0,2 & 1,1 \\
\hline Erdei pocok (Clethrionamys glareolus) & 9,5 & 3,5 & 3,2 & 11,2 & 6,1 & 0,2 & 0,2 \\
\hline Földi pacol (Microtus su hterraneus) & & & & 0,4 & 0,1 & & \\
\hline Mezei pocok (Mifootus arvalis) & 15,6 & 10,5 & 5,2 & 10,3 & 9,1 & 3,1 & 6,6 \\
\hline Csalitjáró pocok (Microtus agrestis) & & & & 0,4 & 0,1 & & \\
\hline Pocok (Mforotus spp.) & 0,9 & 0,9 & 0,4 & 1,6 & 0,9 & 0,2 & 0,3 \\
\hline Rágosáló (Rodentia spp.) & 1,4 & 1,8 & 1,9 & 2,9 & 2,0 & 1,5 & 0,8 \\
\hline Mezeiny úl (Lepus eurapaeus) & & 1,3 & & & 0,3 & & \\
\hline Rag adoz 6́k & - & - & - & 0,4 & $\mathbf{0 , 1}$ & - & - \\
\hline Botz (Meles medes) & & & & 0,4 & 0,1 & & \\
\hline Wh ullatt Sllatak/Csũlk õs vad & 6,6 & 1,8 & 0,2 & 1,6 & 2,0 & - & - \\
\hline Vadd sen6 (Sus scrofa) & & & & 0.4 & 0,1 & & \\
\hline $\mathrm{O}_{\mathrm{z}}$ (Capres lus cap reo hus) & 6,2 & 1,3 & 0,2 & 1,2 & 1,7 & & \\
\hline Grmazarvas (Cervus elaphus) & 0,5 & & & & 0,1 & & \\
\hline Sarvasféle (Cervidae spp.) & & 0,4 & & & 0,1 & & \\
\hline H程iállatak & 5,2 & 1,8 & 6,1 & 2,0 & 4,2 & 14,8 & 19,4 \\
\hline Háżimacska (Felis catus) & 0,5 & & & & 0,1 & & \\
\hline Házinyũ & 0,5 & & 3,0 & 1,6 & 1,6 & 0,6 & 1,0 \\
\hline Juh & & 0,4 & & & 0,1 & 0,2 & 0,1 \\
\hline Kecske/szerv asmarh a & & 0,4 & 0,2 & & 0,2 & 0,2 & 1,0 \\
\hline Sertés & & & & & & 0,4 & 0,7 \\
\hline Barom fiféle & 3,3 & & 2,5 & 0,4 & 1,7 & 3,7 & 12,5 \\
\hline Toj ás (taro mfi) & 0,9 & 1,0 & 0,4 & & 0,5 & 9,7 & 4,1 \\
\hline Madarak & 16,1 & 19,0 & 5,5 & 6,2 & 10,2 & 19,8 & 36,8 \\
\hline Házi veréb (Passe domesticus) & & & & & & 7,5 & 18,4 \\
\hline Cinege (Parus spp.) & & & & & & 0,9 & 2,6 \\
\hline T engelic (Carduelis carduelis) & 0,5 & 1,8 & 0,2 & & 0,5 & 0,2 & 0,7 \\
\hline Füzike (Ploylloscopus spp.) & & 0,4 & & & 0,1 & & \\
\hline Kistestǔ énekesmadăr (Passeriformes spp.) & 14,2 & 14,6 & 5,3 & 6,2 & 8,9 & 10,6 & 14,1 \\
\hline Fácán (Phasianus colchicus) & 0,9 & & & & 0,2 & & \\
\hline Balkáni gerle (Streptopelia deconocto) & 0,5 & & & & 0,1 & & \\
\hline Közepes méretli madár & & & & & & 0,2 & 0,9 \\
\hline T oj & & 2,2 & & & 0,4 & 0,4 & 0,1 \\
\hline Hüllıḱk +ké téltúi ek & - & 0,9 & 0,6 & $\mathbf{0 , 4}$ & 0,5 & - & - \\
\hline Vizisi klá (Natrix natrux ) & & 0,5 & 0,6 & & 0,3 & & \\
\hline Sỉkló (Colubridae sp p.) tojás & & 0,4 & & & 0,1 & & \\
\hline Béka ( $A$ nura spp.) & & & & 0,4 & 0,1 & & \\
\hline Halak & 1,4 & - & - & - & 0,3 & - & - \\
\hline Gerinctele nek & 6,2 & 36,3 & $\mathbf{2 2 , 7}$ & 7,8 & 19,2 & 18,9 & 0,5 \\
\hline Sāō cake (Tet tigonidea spp.) & & & 0,2 & & 0,1 & & \\
\hline Lótūesök (Gryllotalpa gryllotalpa) & & 0,4 & 0,4 & & 0,3 & 0,6 & + \\
\hline Arany pettyes fut rinka (Carabus hortensis) & 0,5 & 11,6 & 0,8 & 0,8 & 2,9 & & \\
\hline Ragyás-/rezes futrinka (Carabus cancellatus/C. ullrichi) & & 9,4 & $\mathbf{3 . 4}$ & & 3,2 & & \\
\hline Kélfuutrinka (Carabus violaceus) & 0,9 & 2,7 & 0,8 & 0,4 & 1,1 & & \\
\hline Borfitrinka (Carabus coriacetus) & & 0,4 & 0,4 & 0,4 & 0,3 & & \\
\hline Arany os bábrabló (Carabus sycophanta) & 0,5 & 0,4 & 0,6 & & 0,4 & & \\
\hline Gy azzutú (Ptenastichus spp.) & & & & & & 2,4 & + \\
\hline Fémfutó (Harpalus spp.) & & & & & & 0,4 & + \\
\hline
\end{tabular}


11. melléklet: folytatása

\begin{tabular}{|c|c|c|c|c|c|c|c|}
\hline Futóbogarir (Carabidae spp.) & 1,4 & 1,3 & 2,8 & & 1,6 & 0,4 & + \\
\hline Pattanólog gér (Elateridae spp) & & 0,4 & 0,2 & & 0,2 & & \\
\hline Srarvasbo gír (Lucamus cervus) & & & 4,2 & & 1,7 & & \\
\hline Tavagzi gançjtứró (Gen trupes vernalis) & & & 0,2 & & 0,1 & & \\
\hline Erdei-kö̈zönségs galacsimh ajtó (Gentrupes spp.) & & 0,4 & 0,6 & & 0,3 & & \\
\hline Galacsinhajtó (Scarabeidee spp.) & & & 0,2 & & 0,1 & 0,2 & + \\
\hline Arany os tózsabo gár (Cetonia auraua) & & & 0,6 & & 0.3 & & \\
\hline Ró zabagár (Cetonia spp.) & & & & & & 0,9 & + \\
\hline Majusi sserebogár (Melolon th a melolon tha) & & 1,3 & 0,2 & & 0,3 & & \\
\hline Csereb gar (Melolonthidae spp.) & & & 0,2 & & 0,1 & 1,3 & + \\
\hline Bogir (Coleoptera spp.) & 0,9 & 0,4 & 0,2 & & 0,3 & 2,9 & + \\
\hline Bogár (Coleoptera spp.) lárva & & & & & & 0,6 & + \\
\hline Kék fadongó (Xylocopa valga) & & & & & & 0,4 & + \\
\hline Német daréx (Paravespula germanica) & & & 0,2 & & 0,1 & & \\
\hline Padláschrázs (Polistes nimfa) & & & 0,2 & & 0,1 & 1,3 & + \\
\hline Tódrázs (Vespa crabro) & & & & 0,4 & 0,1 & 0,4 & + \\
\hline Dartass (Vespidae spp.) & & & 0,2 & & 0,1 & 4,6 & 0,1 \\
\hline Daráss (Vespidae spp.) lárva & & & & & & 0,2 & + \\
\hline Háximéh (Apis me ellifero ) & & & & & & 0.2 & + \\
\hline Erdei vōrō shangya (Formica rufa) & & & & 0,4 & 0,1 & & \\
\hline Hártyásszám yó (Hymenop tera spp.) & 0,5 & 1,3 & 0,2 & & 0,4 & & \\
\hline Rovar (Insecta spp.) & 1,4 & 6,3 & 5,1 & 5,4 & 4,7 & 1,3 & 0,1 \\
\hline Rovar (Insecto spp.) lárva & & & & & & 0,4 & + \\
\hline Csiga (Gastropoda spp.) & & & 0,6 & & 0,3 & 0,4 & + \\
\hline Növén nye k & 24,2 & 4,4 & 45,8 & 45,1 & 33,6 & 31,0 & 15,2 \\
\hline Szb 16 (Kitis vin iffera) & 0,5 & & 0,8 & 10,7 & 2,7 & 3,7 & 1,0 \\
\hline Cxeresmye (Cerasus a aium) & & 1,3 & 23,5 & 0,8 & 10,0 & 4,4 & 5,3 \\
\hline Meggy (Cerasus vulgaris) & 0,9 & 0,4 & 3,6 & & 1,7 & 1,5 & 0,9 \\
\hline Húsos som (Cormus mas) & 0,9 & & 0,6 & 2,5 & 1,0 & & \\
\hline Szamóca/málha (Fragaria/Rubus spp.) & & 1,3 & 6,0 & & 2,7 & 1,1 & + \\
\hline Szzder (Ru bus spp.) & & & 3,8 & 3,7 & 2,3 & 0,4 & + \\
\hline Epe (Mn rus spp.) & & & & & & 0,2 & + \\
\hline Rïbizli (Rihes spp.) & & & & & & 0,2 & + \\
\hline Csipkebogyó (R osa canina ) & 7,6 & & & 2,0 & 1,8 & 0,4 & 0,2 \\
\hline Kökény (Prunus spinosa) & 9,0 & & & 15,6 & 4,9 & 0,4 & 0,4 \\
\hline Sxilva (Prunus domestica) & & & 2,9 & 2,5 & 1,7 & 1,7 & 2,2 \\
\hline Alma (Malus spp.) & & & & & & 1,5 & 0,7 \\
\hline Körte (Pyrus spp.) & & & & & & 1,1 & 0,3 \\
\hline Gyümō les, megh at ḱtrozhatatlan & & & 1,7 & 1,2 & 1,0 & 6,8 & 1,8 \\
\hline Bíza ( Triticum aextivum ) & 0,5 & & & & 0,1 & 0,2 & + \\
\hline Arpa (Hordeum spp.) & & & & & & 0,4 & + \\
\hline Kukorica (Zea mays) & 1,4 & & 0,2 & 0.4 & 0,4 & 0.4 & 0,1 \\
\hline Napraforgó (Helianthus annus) & 0,5 & & 0,2 & & 0,2 & 1,9 & 0,7 \\
\hline Borostyân (Hedera helix) & 0,5 & & & 0,8 & 0,3 & & \\
\hline Mag & & & 0,6 & 1,2 & 0,5 & 0,4 & 0,1 \\
\hline Levêl & 0,5 & 0,9 & & & 0,3 & & \\
\hline Pázsitfufák (Gramineae spp.) & 1,9 & 0,5 & 1,9 & 2,9 & 1,8 & 3,9 & 1,0 \\
\hline Kender (Cannabis sativa) & & & & & & 0,2 & 0,3 \\
\hline Paprika & & & & & & 0,2 & + \\
\hline Virág & & & & 0,4 & 0,1 & & \\
\hline Gy \&kény/sás (T,pha/Carex spp.) & & & & 0,4 & 0,1 & & \\
\hline Fuy b b & & & & & (eset) & (wet) & \\
\hline Nylon/mfan yag darabka & & & & + & -1 & -1 & \\
\hline Horgászyzininá r & & & & & & -2 & \\
\hline Mủanyag kōtōzõzssin ór & & & & & & -2 & \\
\hline Gumidarab & & & & & & -8 & \\
\hline Kondom & & & & & & -1 & \\
\hline Szalámihá̧ & & & & & & -1 & \\
\hline Tejeszacskó & & & & & & -1 & \\
\hline Mübớt & & & & & & -1 & \\
\hline Alumínium fólia & & & & + & -1 & -5 & \\
\hline Ūvegdarab & & & & & & -1 & \\
\hline Cérna & & & & & & -2 & \\
\hline Papir & & & & + & -1 & -3 & \\
\hline Tégadarab & & & & & & -2 & \\
\hline Kályha salak & & & & & & -1 & \\
\hline Kavics & & & + & & -1 & -4 & \\
\hline Mintaszám (n) & 124 & 107 & 211 & 130 & 572 & 151 & \\
\hline Táplálék-al kotók szá́ma (k)* & 211 & 226 & 476 & 244 & 1157 & 465 & \\
\hline$k / n$ & 1.7 & 2.1 & 2.3 & 1.9 & 2.0 & 3.1 & \\
\hline
\end{tabular}


12. melléklet: A nyuszt évszakonkénti táplálék-összetétele

Jelmagyarázat: E\% = relatív elöfordulási gyakoriság, \%; B\% = biomassza számítás szerinti összetétel, \%; + = előfordulás 0,5\% alatt

\begin{tabular}{|c|c|c|c|c|c|c|c|c|c|c|c|c|c|c|c|c|}
\hline \multirow{3}{*}{ Traplálék taxon } & \multicolumn{8}{|c|}{ 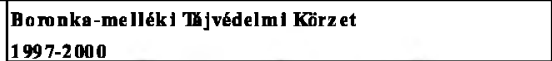 } & \multicolumn{8}{|c|}{$\begin{array}{l}\text { Lankócl erdó (Gyékényeas) } \\
\text { 2000-2m1 }\end{array}$} \\
\hline & \multicolumn{2}{|c|}{\begin{tabular}{|l|l|l|l} 
Tél \\
\end{tabular}} & \multicolumn{2}{|c|}{ TT avasz } & \multicolumn{2}{|l|}{ INyár } & \multicolumn{2}{|l|}{ |Ös? } & & \multicolumn{2}{|c|}{$\mathrm{IT}_{\mathrm{Tavasz}}$} & \multirow{2}{*}{$\frac{\mid \mathrm{Nyqir}}{\mathrm{E} \%}$} & \multicolumn{3}{|c|}{$106 \mathrm{sz}$} \\
\hline & $\mathrm{E} \%$ & $\mathrm{~B} \%$ & $\mathrm{E} \%$ & $\mathbf{B \%}$ & $\mathrm{E} \%$ & $\mathbf{B} \%$ & $\mathrm{E} \%$ & $\mathrm{~B} \%$ & $\mathrm{E} \%$ & $\mathrm{~B} \%$ & $\mathbf{E} \%$ & $\mathrm{~B} \%$ & & $\mathrm{~B} \%$ & $\mathrm{E} \%$ & $\mathrm{~B} \%$ \\
\hline Kis -és kōzepes e mlósö́k & 40,6 & 53,4 & 32,4 & 55,9 & 28,2 & 26,6 & 36,6 & 49,4 & 51,0 & 76,0 & 43,1 & 79,6 & 39,1 & 68,6 & 31,4 & 68,5 \\
\hline Vakond (Talpa europaea) & & & & & & & & & 1,0 & 0,3 & & & & & & \\
\hline Erdei cickány (Sorex araneus) & 0,7 & 0,2 & 0,5 & 0,1 & 0,8 & 2,3 & & & 3,0 & 5,8 & 0,8 & 1,3 & 0,3 & 0,8 & & \\
\hline $\begin{array}{l}\text { Meree cickány (Crocidura leucodon) } \\
\text { Käz }\end{array}$ & 0,7 & 0,6 & & & & & & & & & 1,5 & 1,2 & & & & \\
\hline $\begin{array}{l}\text { Közzönséges vízicickány (Neomys fodiens) } \\
\text { Gickány (Soricidae spp.) }\end{array}$ & & & 0,5 & 2,6 & 1,5 & & & & $\begin{array}{l}1,0 \\
3,9\end{array}$ & $\begin{array}{l}3,1 \\
6,2\end{array}$ & & 7,7 & 2,4 & 4,5 & 0,9 & 0,7 \\
\hline Mókus (Sciurus vulgaris) & & & & & 0,4 & 0,1 & & & & & & & & & & \\
\hline Nagy pele (Myoxusglis) & 0,7 & 1,4 & 0,9 & + & & & 0,7 & 1,5 & 1,0 & 2,8 & & & & & & \\
\hline $\begin{array}{l}\text { Mogyorós pele (Muscardinus avellana russ) } \\
\text { Peleféle (Myaxidae spp.) }\end{array}$ & & & 0,5 & & & & & & & & 0.8 & & 0,3 & + & & \\
\hline Kōzönnséges erdeieger (Apodemus sylvaticus) & 4,4 & 5,6 & 4,5 & 5,5 & 4,5 & 3,5 & 6,3 & 14,3 & 2,9 & 3,7 & 3,1 & 3,5 & 3,4 & 3,5 & 7,4 & 16,7 \\
\hline Săr ganyakú edeiegḱr (Apodem us flavicol & 5,8 & 9,3 & 2,3 & 3,7 & 4,1 & 3,0 & 2,8 & 1,8 & 3,9 & 5,8 & 0,8 & + & 0,7 & 0,5 & 2,8 & 3,1 \\
\hline Pirókegét & & & 0,5 & 0,6 & 0,8 & 0,4 & & & 1,0 & 3,1 & 0,8 & 0,2 & 0,3 & 0,1 & & \\
\hline $\begin{array}{l}\text { Erdeieger (Apodemus spp.) } \\
\text { Törpeegלt (Mcromys minutus) }\end{array}$ & 0,7 & 0,6 & 1,4 & 1,6 & $\begin{array}{l}3,0 \\
0,8\end{array}$ & $\begin{array}{l}0,7 \\
0,3\end{array}$ & 7,0 & 10,8 & 7,8 & 10,6 & & & $\begin{array}{l}1,7 \\
1,0\end{array}$ & $\begin{array}{l}2,5 \\
1,6\end{array}$ & 0,9 & 0,9 \\
\hline Erdei pocok (Clethrionomys glareo hus) & 26,2 & 34,3 & 20,3 & 39,7 & 10,5 & 15,1 & 19,1 & 20,9 & 14,7 & 16,2 & 15,3 & 31,7 & 15,0 & 27,6 & 15,7 & 32,7 \\
\hline Mezei pocok (Mic & 0,7 & 1,3 & 0,5 & 1,9 & & & & & 9,8 & 15,7 & 10,0 & 20,4 & 8,8 & 15,7 & 2,8 & 12,4 \\
\hline Földi pocok (Microtus subterraneus) & & & & & & & & & & & 1,5 & 2,4 & & & & \\
\hline Cealitjáró pocok (Micro tus agrestis) & & & & & & & & & & & 0,8 & 1,2 & 2,7 & 7,8 & & \\
\hline Pocok (Microtus spp.) & & & & & & & & & & & 0,8 & 0,9 & 0,3 & 1,2 & & \\
\hline Vizipocok (Arvicala terrestris) & & & & & & & & & 1,0 & 2,8 & 2,3 & 5,3 & 2,0 & 2,7 & 0,9 & 2,0 \\
\hline Rágrcsáló (Roden tia spp.) & 0,7 & + & 0,5 & 0,2 & 1,5 & 0,2 & 0,7 & 0,1 & & & & & & & & \\
\hline Mezeinyúl (Iepus europa eus) & & & & & 0,4 & 0,1 & & & & & 0,8 & 3,7 & & & & \\
\hline Csũlkö̈s vadak & 23,2 & 29,6 & 8,1 1 & 6,5 & 1,1 & 0,8 & 0,7 & 0,3 & 2,0 & 0,3 & 2,3 & $\mathbf{n , 1}$ & 0,3 & 0,1 & 1,9 & 0,2 \\
\hline Vaddisznó (Sus scrofa) & 9,3 & 23,2 & 2,2 & 3,9 & 0,4 & 0,1 & & & 1,0 & 0,1 & & & 0,3 & 0,1 & 0,9 & 0,2 \\
\hline$\sigma_{z}$ (Capreobus capreouss) & 7,3 & 4,1 & 4,5 & 1,6 & 0,3 & + & & & & & 1,5 & + & & & 0,9 & + \\
\hline Gmszarvas (Cervus elaphus) & 4,4 & 1,7 & 0,9 & 0,8 & 0,4 & 0,7 & 0,7 & 0,3 & 1,0 & 0,2 & & & & & & \\
\hline Szarvasféle (Cervidae spp.) & 2,2 & 0,6 & 0,5 & + & & & & & & & 0,8 & 0,1 & & & & \\
\hline Madarak & 6,5 & 8,2 & 14,4 & 26,6 & $12, \mathrm{~s}$ & 21,2 & $\mathbf{9 , 2}$ & 16,0 & 14,7 & 14,9 & 19,2 & $15, \mathrm{~g}$ & 20,4 & 15,6 & 4,6 & 3,9 \\
\hline Tengelic (Carduelis carduelis) & 0,7 & 1,2 & & & & & & & & & & & & & & \\
\hline Csuszka (Sitta europaea) & & & 0,9 & 1,4 & & & 2,1 & 3,3 & & & 2,3 & 4,0 & 0,3 & 0,1 & & \\
\hline $\begin{array}{l}\text { Ókörszem (Troglodytes troglodytes) } \\
\text { Kék cinege (Pants coeruleus) }\end{array}$ & & & 0,5 & 1,5 & & & & & 2,0 & 5,0 & 0,8 & 0,2 & & & & \\
\hline Kistesth énekesmadir (Passeriformes spp.) & 5,1 & 4,8 & 12,1 & 23,4 & 12,8 & 21,2 & 7,1 & 12,7 & 12,7 & 9,9 & 10,0 & 10,7 & 19,4 & 14,4 & 3,7 & 2,2 \\
\hline | Mátýssmadár (Garru us glandar & & & & & & & & & & & & & & 1,1 & & \\
\hline
\end{tabular}


12. melléklet: folytatása

Harkály (Picidae spp.) Réce (Anas spp.) Kōzepes vízimadín

Tojass

Hullikk+két litúek

VTisikikló (Natrix natria)

Gyik (Sauria spp.)

Hưllo (Reptilia spp.)

Tavi-/kecskebéka (Rana spp.)

Béka (Anura sp p.)
Hal ak

Hal ak
Naphal (Lepom is gib bo sus )

Naphal (Lepom is gibbo
Siger (Perca fluviatilis)

Exüstkarász: (Carassius a aura tus gibelio)

Amir (Clenopharing od on idella)

Csuka (Esox lucius)

Sillō (Luciopera bucioperoa)

Hal, meghatározh at at lan

Gerinctelene k

Ssska (Acrioiden spp.)

ótilicsök (Grillotalpa gryllo talpa)

Aranyos babrabló (Calosoma sycophanta)

Aranypettyes furinka (Carabus hortensis)
Ragyasstezes futrinka (Carabus cancellatus/C, ullichi)

Ragyástrezes futrinka (Carabus cas

Kékfutrinka (Carabus violaceus)
Börfưtrinka (Carabus coriaceus)
Gýassfutó (Pterostichus spp.)

Gyasufuthó (Pterossichuss

Cabonafutrinka (Zabrus tenebrioides)

Futóbogán lárva (Carabid ae spp.)

Futobbogár (Carabidae spp.)

Sirrgagzegélyly csikbo gir (Ditiscus mangina lis)

Sparvasbogar (Iucanus ceruss)

Kis szarvasbogir (Dorcusparallelep ipedus)

Rézsabogar (Cetoniz spp.)

Cincér (Cerambycidae spp.)

Erdei-/kōzönséges ganéfiứó (Geotrupes spp.)

Calacsinhajtó (Scarabeidae spp.)

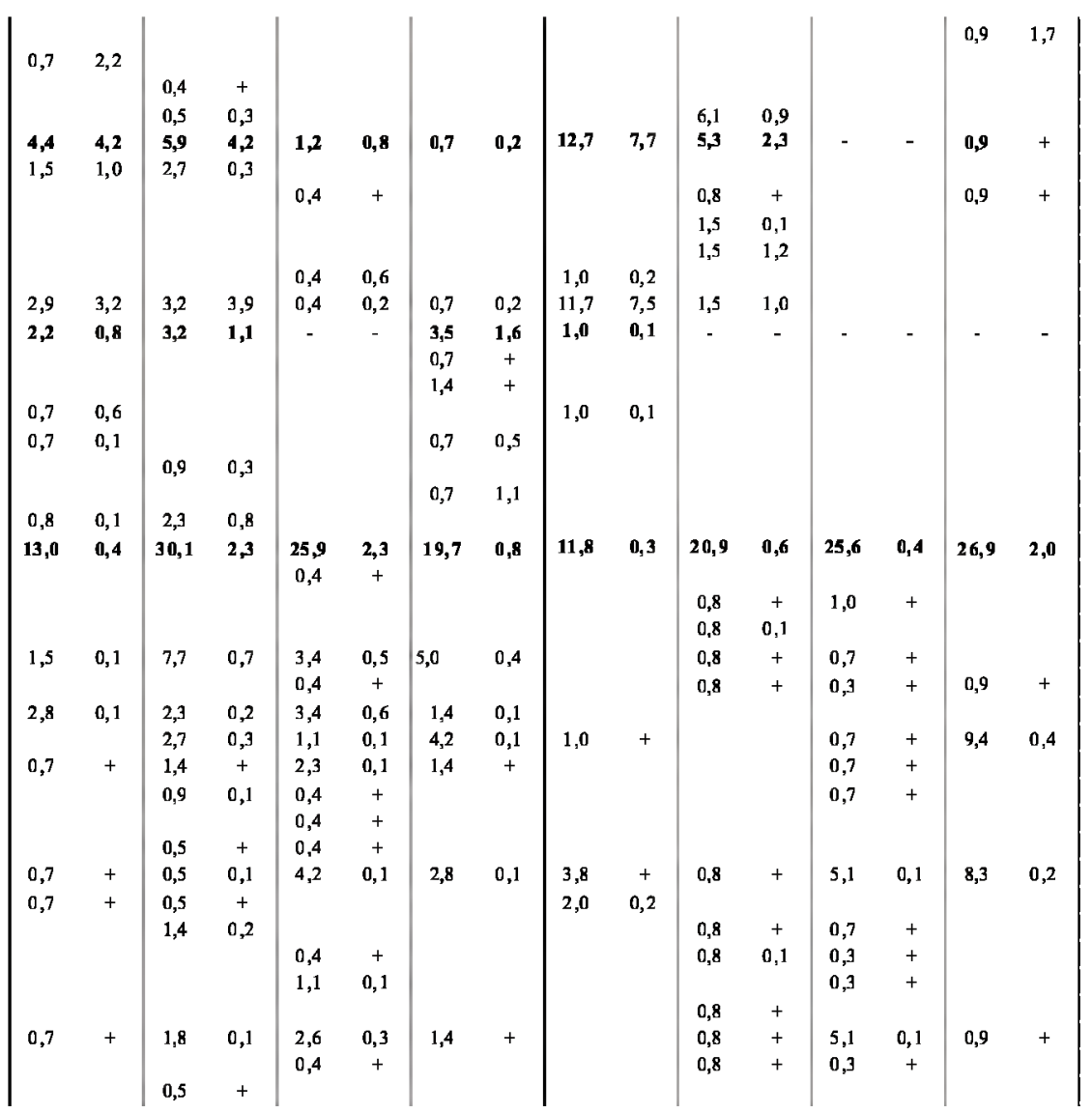


12. melléklet: folytatása

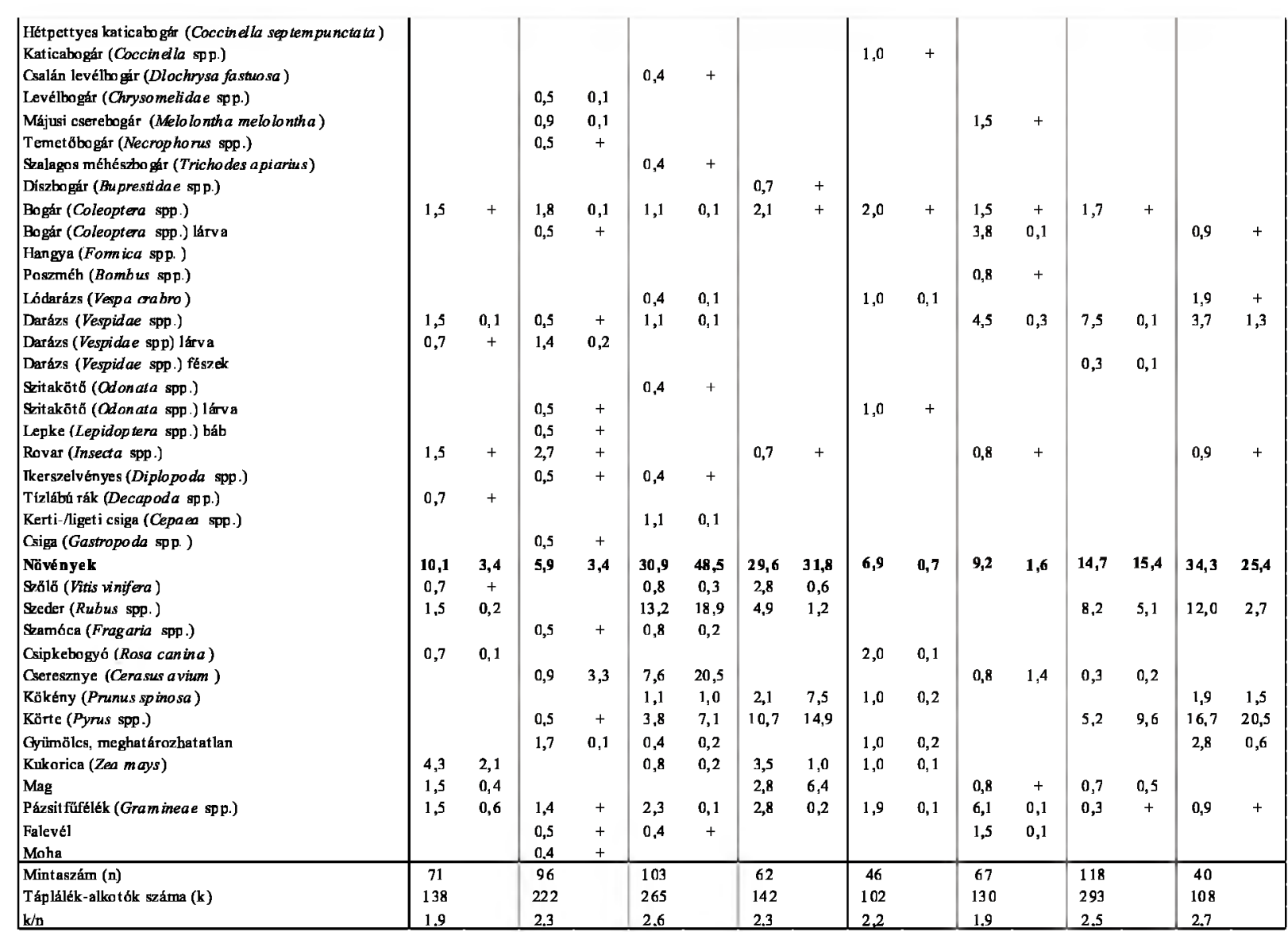


13. melléklet: A borz évszakonkénti táplálék-összetétele mezőgazdasági és erdei élőhelyen

Jelmagyarázat: $\mathrm{E} \%=$ relatív elófordulási gyakoriság, \%; B\% = biomassza számítás szerinti összetétel, $\% ;+=$ elófordulás $0,5 \%$ alatt

\begin{tabular}{|c|c|c|c|c|c|c|c|c|c|c|c|}
\hline \multirow{3}{*}{ Táplálé k taxon } & \multicolumn{3}{|c|}{\begin{tabular}{|l|} 
Fon6i halastó \\
kōrzete 199 1-1997 \\
\end{tabular}} & \multicolumn{8}{|c|}{$\begin{array}{l}\text { Boronka-me lléki TYj jú de lmi Körze t } \\
\text { 1997-2000 }\end{array}$} \\
\hline & Tavas: & Nyár & $\delta_{\mathrm{sz}}$ & Tél & & Tavsz & & Ny的 & & Ösz $_{\mathrm{sz}}$ & \\
\hline & \multicolumn{3}{|c|}{ Elöfordulási gyakorisa } & E E & B\% & $\mathrm{E} \%$ & $\mathrm{~B} \%$ & $\mathbf{E} \%$ & B\% & $\mathrm{E} \%$ & $\mathrm{~B} \%$ \\
\hline Kisemlós $\operatorname{se}$ & 4,0 & 16,7 & 30,0 & $\mathbf{3 , 1}$ & 1,2 & 2,2 & 2,6 & 2,4 & 1,8 & 9,7 & 12,2 \\
\hline Cickány (Soricidae spp.) & & & & & & 0,7 & 0,8 & 0,8 & 0,5 & & \\
\hline Käzön séges erdeiegér (Apodem us & & & & & & & & & & & \\
\hline sylvaticus ) & & & & 1,0 & 0,5 & & & & & 3,3 & 1,5 \\
\hline $\begin{array}{l}\text { Sárgan yakú erdeiegé (Apodem us } \\
\text { flavicollis) }\end{array}$ & & 6,7 & & & & & & & & & \\
\hline F rdeiegér (Apodemus spp.) & 1,6 & & 5,0 & & & 0,2 & 0,1 & & & & \\
\hline Törpeegé (Micromys minutus) & & & & & & & & & & 1,6 & 0,1 \\
\hline Vándorpatkány (Ra ttus norvegicus) & & & & & & & & & & 1,6 & 0,2 \\
\hline Erdej pocok (Clethrionomys gla reohss) & 0,8 & 3,3 & & 1,0 & 0,5 & 1,1 & 1,7 & 0,8 & 1,0 & 1,6 & 7,4 \\
\hline Mezi poøk (Microtus arvalis) & 0,8 & 6,7 & 20,0 & & & & & & & & \\
\hline Csal itjáró poook (Mforotus agrestis) & & & & & & & & 0,8 & 0,3 & & \\
\hline Rágcsáló (Rodentia spp.) & 0,8 & & 5,0 & 1,1 & 0,2 & 0,2 & + & & & 1,6 & 3,0 \\
\hline Ragado z6́k & - & 5,0 & - & - & - & - & - & 0,8 & + & 1,6 & 0,1 \\
\hline Nyust (Mantes martes) & & & & & & & & 0,8 & + & & \\
\hline Menyá féle (Mustelidae sp p.) & & 5,0 & & & & & & & & & \\
\hline Kuty a (Can is fam iliaris) & & & & & & & & & & 1,6 & 0,1 \\
\hline Elhullatt Ǵllatok/csülkös va dak & 0,8 & - & 5,0 & 8,2 & 0,8 & 0,5 & + & - & - & - & - \\
\hline Vaddisznó (Sus scrofa) & & & 2,5 & & & & & & & & \\
\hline Öz (Capreolus capreolus) & & & 2,5 & 2,1 & 0,3 & & & & & & \\
\hline Gimszarvas (Cervus elaphus) & & & & 6,1 & 0,5 & 0,2 & + & & & & \\
\hline Szarvasféle (Cervidae spp.) & 0,8 & & & & & 0,3 & + & & & & \\
\hline Madarak & 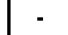 & 6,7 & - & - & - & 1,4 & 0,4 & 0,8 & $\mathbf{0 , 2}$ & 1,6 & + \\
\hline Kistestú én ek esmadát (Passerifo mes spp.) & & 5,0 & & & & 0,9 & 0,4 & 0,8 & 0,2 & 1,6 & + \\
\hline Fácán (Phasianus colchicus) & & 1,7 & & & & & & & & & \\
\hline Tojás & & & & & & 0,5 & + & & & & \\
\hline Hüllók k+kétél ltúe k & 1,6 & $\mathbf{1 , 7}$ & - & 18,6 & 43,0 & 26,3 & $\mathbf{7 6 , 1}$ & 21,1 & $\mathbf{7 5 , 4}$ & 16,1 & 57,9 \\
\hline Mocsári teknõ s (Emys orbicularis) tojás & & & & & & & & 3,8 & 11,0 & & \\
\hline Vizisik ló (Natrix na trix) & & & & 1,0 & + & 0,2 & 0,1 & & & & \\
\hline Vízisik ló (Nafrix natrix) toj & & 1,7 & & & & & & & & & \\
\hline Gyik (Sauria spp.) & & & & & & 0,2 & 0,3 & 1,5 & 2,0 & & \\
\hline Hüllb (Reptilia spp.) & & & & & & 1,1 & 0,2 & & & & \\
\hline Barna varangy ( $B u f o b u f o$ ) & & & & 3,1 & 7,9 & 5,3 & 16,1 & 1,5 & 13,3 & 6,5 & 35,7 \\
\hline Kecske béka (Rana esculen ta) & & & & 9,4 & 26,3 & 11,7 & 38,8 & 6,7 & 33,3 & 6,5 & 14,3 \\
\hline Barna ásóbéka (Pelobates fuscus) & & & & & & 3,0 & 10,6 & 1,5 & 7,6 & & \\
\hline Zöld levelibéka ( $H y$ & & & & 1,0 & + & 3,2 & 6,7 & 2,3 & 5,6 & 3,1 & 7,9 \\
\hline Unka (Bombina spp.) & & & & & & 0,5 & 0,4 & 0,8 & 1,3 & & \\
\hline Béka (Anura spp.) & 1,6 & & & 4,1 & 8,8 & 1,1 & 2,9 & 3,0 & 1,3 & & \\
\hline Halak & - & - & - & 1,0 & $\mathbf{0 , 1}$ & - & - & - & - & 1,6 & 0,1 \\
\hline Hal, meghatáro th at at lan & & & & 1,0 & 0,1 & & & & & 1,6 & 0,1 \\
\hline $\begin{array}{l}\text { Ge rin cte len ek } \\
\text { Lótücsök (Gryllotalpa gग) }\end{array}$ & 66,9 & $\begin{array}{c}\mathbf{5 3 , 3} \\
1,7\end{array}$ & $\mathbf{2 5 , 0}$ & 37,1 & 49,2 & 64,6 & 18,7 & 61,5 & 5,5 & 45,2 & 3,8 \\
\hline Aranypatyes futrinka (Ca rab us horten sis) & 7,3 & 5,0 & & 2,1 & + & 1,4 & + & 3,8 & 0,1 & 3,2 & + \\
\hline Ragyás futrinka (Carabus ca & 9,7 & 5,0 & & & & 0,7 & + & 0,8 & + & 1,6 & + \\
\hline Kék futrink a (Carabus violaceus) & 3,2 & 3,3 & & & & & & 2,3 & 0,1 & & \\
\hline Bốrfutrinka (Carabus coriaceus) & 1,6 & & & & & 0,5 & + & 3,0 & 0,1 & 3,2 & + \\
\hline Gabonafutrinka (Zabrus tenebrioides) & 0,8 & & & & & & & & & & \\
\hline Gyászfutó (Pterostichus spp.) & & & & & & 1,4 & + & 3,8 & 0,2 & & \\
\hline Fémfutó (Harpalus spp.) & & & & & & 0,5 & + & 0,8 & + & 1,6 & + \\
\hline Futóbogár (Carabidae sp p.) & 4,8 & & 2,5 & & & 1,8 & + & 1,5 & + & 1,6 & + \\
\hline Futóbogár (Carabidae spp.) lárva & & & & & & 1,4 & + & & & & \\
\hline T avaszi gáfítúó (Geotrupe vernalis) & 1,6 & & & 5,2 & 0,4 & 7,5 & 0,6 & 5,3 & 0,1 & & \\
\hline Ganejtúnó (Geotrupes sp p.) & 3,2 & 10,0 & & 9,3 & 0,8 & 16,3 & 1,6 & 12,7 & 0,8 & 9,7 & 2,2 \\
\hline Galacsin hajtó (Sca rabeidae spp.) & 0,8 & & & & & 0,5 & + & & & & \\
\hline Ormány osbo gár (Curculion idae spp.) & & & & & & 0,2 & + & & & & \\
\hline Pattanóbogár (Elateridae spp.) & & & & & & 1,1 & + & 2,3 & + & & \\
\hline Kat icabogár (Coocin ella sp p.) & & & & & & 2,3 & + & 0,8 & + & & \\
\hline Levélbogár (Chyso melidae spp.) & 0,8 & & & & & 0,5 & + & 0,8 & + & & \\
\hline Disbogár ( $B$ up restida e sp p.) & & & & & & 0,5 & + & & & & \\
\hline
\end{tabular}


13. melléklet: folytatása

\begin{tabular}{|c|c|c|c|c|c|c|c|c|c|c|c|}
\hline Szarvasbogár (Lucan us cervus) & & 3,3 & & & & & & & & & \\
\hline Aranyos rózsabogár (Cetonia a urata) & 1,6 & & 5,0 & & & & & & & & \\
\hline Rózsabotóǵr (Cetonia spp.) & & & & & & & & 0,8 & 0,1 & & \\
\hline Májusi cserebogar (Melolon tha melolon tha) & 0,8 & & & & & & & & & & \\
\hline Virágcincér (Leptura spp.) & & & & & & & & 0,8 & + & & \\
\hline Nagy hõ scincér (Cerambyx cerdo) & & & & & & & & 0,8 & + & & \\
\hline Bogár (Coleoptera spp.) & 0,8 & 6,7 & & & & 1,8 & + & 0,8 & + & & \\
\hline Bogár (Coleoptera spp.) lárva & & & & & & 0,2 & + & & & & \\
\hline Hangy a (Formicidae spp.) & & & & & & 0,2 & + & 0,8 & + & & \\
\hline Lódarázs (Vespa crabro) & 4,0 & & & & & 0,2 & + & & & 1,6 & + \\
\hline Darázs (Vespidae spp.) & 0,8 & & & & & 0,2 & + & 4,5 & 0,2 & & \\
\hline Darázs (Vespidae spp.) fészek & 0,8 & & & & & & & & & & \\
\hline Hártyásszárnyú (Hymen op tera spp.) & & & 2,5 & & & & & & & & \\
\hline Szitakötó (Odonata spp.) lárva & & & & & & 1,8 & + & & & & \\
\hline Rovar (Insecta spp.) & 0,8 & 3,3 & 2,5 & & & 0,5 & + & & & 1,6 & + \\
\hline Ikerszelvényes (Diplopoda spp.) & & & & 2,1 & + & 5,3 & 0,1 & 2,3 & + & & \\
\hline Ászk arák (Isopoda spp.) & & & & & & 0,5 & + & & & & \\
\hline Kerti-/liget i csiga(Cepqea spp.) & & & & & & 0,2 & + & & & & \\
\hline Nagy balogesig (Aplexa hyno num) & & & & & & 0,2 & + & & & & \\
\hline Csiga (Gastropoda spp.) & & & & 1,0 & + & 0,5 & + & 1,5 & + & 1,6 & + \\
\hline Gyürülsféreg (Annelida spp.) & 23,5 & 15,0 & 12,5 & 17,4 & 47,9 & 16,4 & 16,1 & 11,3 & 3,5 & 19,4 & 1,4 \\
\hline Nö vény ek & 26,6 & 16,7 & 40,0 & 32,0 & 5,7 & $\mathbf{5 , 0}$ & 2,2 & 13,5 & 17,1 & 24,2 & 25,9 \\
\hline Szolo (Vitis vinifera) & & & & & & & & & & 1,6 & 0,1 \\
\hline Szeder ( $R u b u s$ spp.) & & 1,7 & 2,5 & & & & & 4,5 & 2,3 & 1,6 & 4,6 \\
\hline Szamóca (Fragaria spp.) & & & & & & 0,2 & 0,6 & 2,3 & 8,5 & & \\
\hline Cseresznye (Cerasus avium) & & 6,7 & 5,0 & & & 0,2 & 0,1 & & & & \\
\hline Kö kén y (Prun us sp in asa) & & & & & & & & & & 1,6 & 9,7 \\
\hline Csipk eb gyó (Rosa canina) & 0,8 & & 2,5 & & & & & & & & \\
\hline Körte (Pyrus spp.) & & & & & & & & 3,0 & 5,6 & 6,5 & 6,6 \\
\hline Kuk orica (Zea mays) & 23,8 & 3,3 & 27,5 & 13,5 & 5,1 & 2,1 & 1,2 & & & 4,8 & 4,2 \\
\hline Napraforgó (Helian thus a nn us) & 0,8 & 3,3 & 2,5 & & & & & & & & \\
\hline Mag & 1,2 & & & 10,3 & 0,2 & & & & & 3,2 & 0,6 \\
\hline Pázsitfüfélék (Gram in ea e spp.) & & 1,7 & & 5,2 & 0,4 & 1,8 & 0,3 & 3,8 & 0,6 & 4,8 & 0,1 \\
\hline Falevél & & & & 1,0 & + & 0,5 & + & & & & \\
\hline Feny ôtú & & & & 1,0 & + & & & & & & \\
\hline Rigy & & & & 1,0 & + & 0,2 & + & & & & \\
\hline Mintaszám (n) & 43 & 14 & 14 & 25 & & 96 & & 19 & & 16 & \\
\hline Táp lálék-alkotók száma (k) & 124 & 60 & 40 & 97 & & 438 & & 133 & & 62 & \\
\hline $\mathrm{k} / \mathrm{n}$ & 2.9 & 4,3 & 2,9 & 3.9 & & 4,6 & & 7,0 & & 3,9 & \\
\hline
\end{tabular}


14. melléklet: A vörösróka évszakonkénti táplálék-összetétele mezőgazdasági élőhelyeken

Jelmagyarázat: E\% = relatív előfordulási gyakoriság, \%; B\% = biomassza számítás szerinti összetétel, \%; + = előfordulás $0,5 \%$ alatt; * erdei élóhely; ** tél-koratavasz

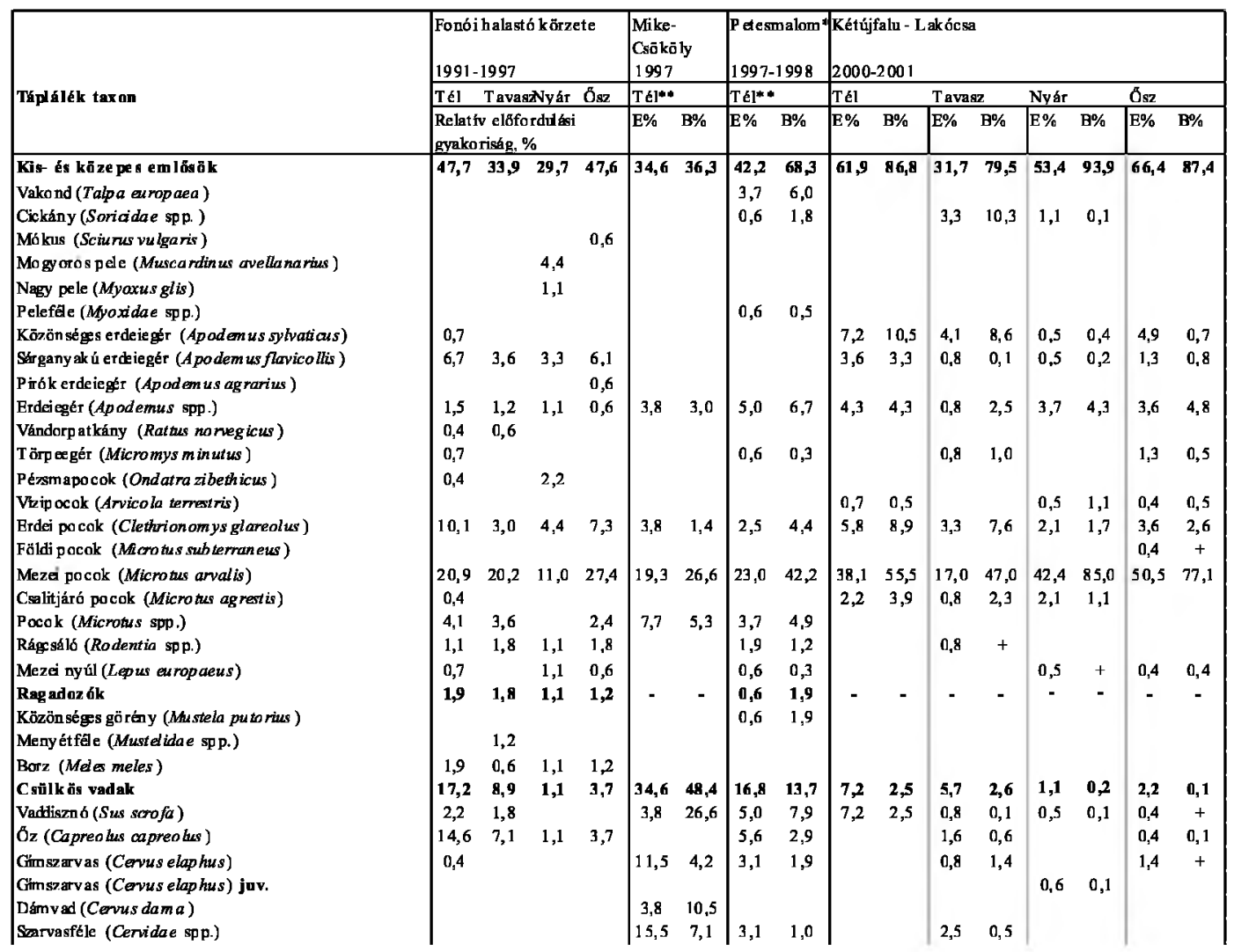




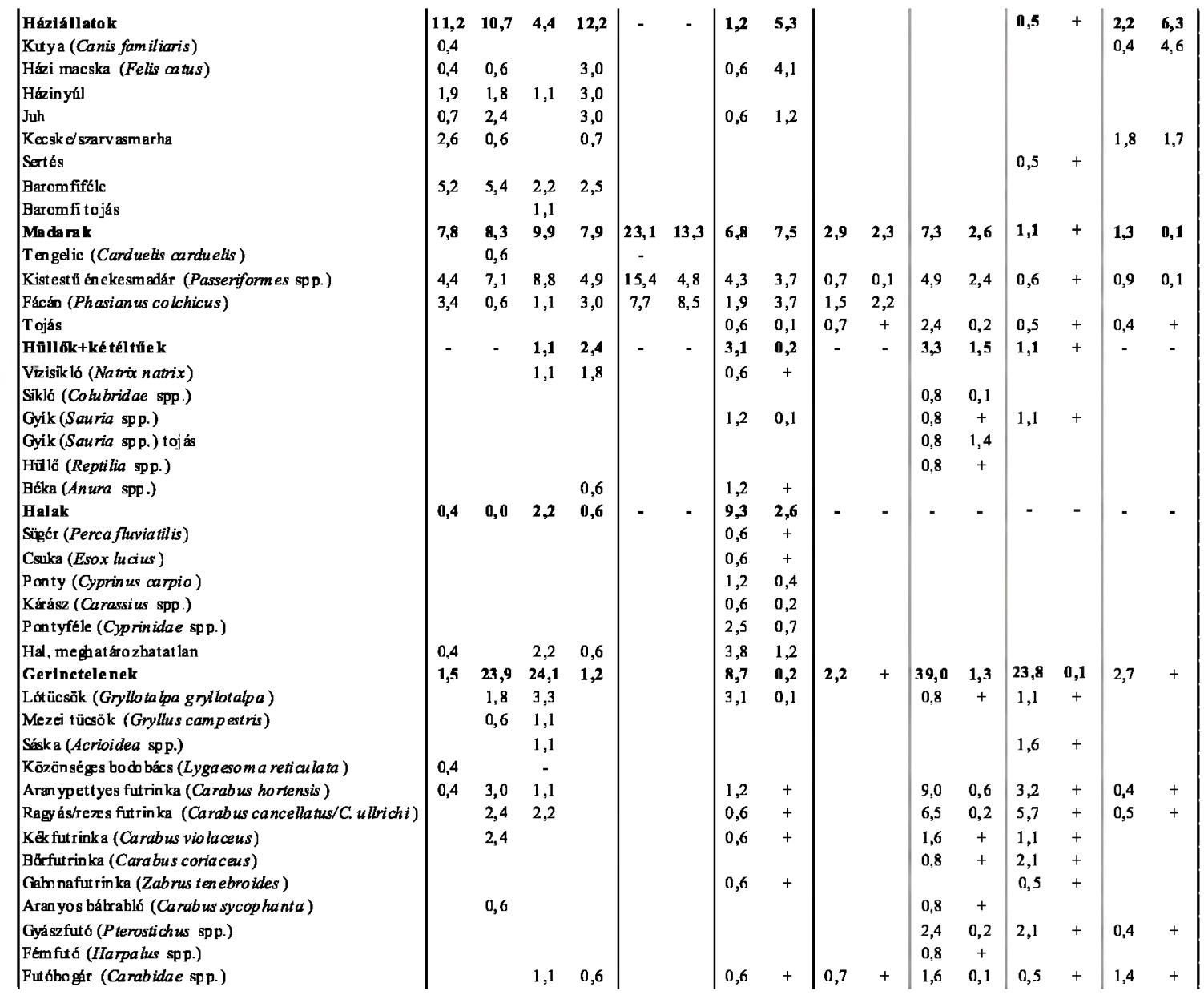


14. melléklet: folytatása

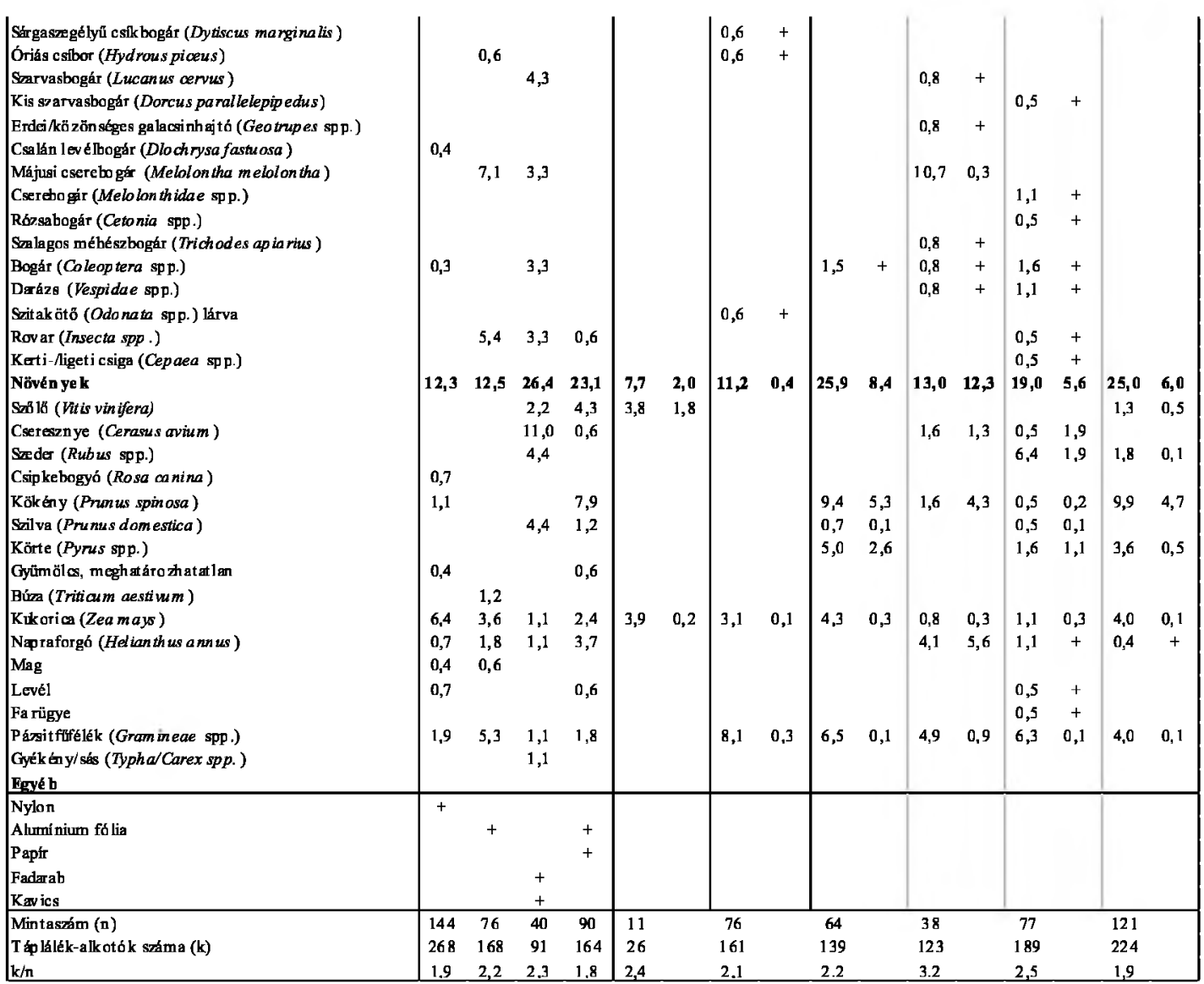


15. melléklet: A vörösróka évszakonkénti táplálék-összetétele erdei élőhelyeken

Jelmagyarázat: $\mathrm{E} \%$ = relativ előfordulási gyakoriság, \%; $\%$ \% biomassza számítás szerinti összetétel, $\% ;+=$ előfordulás $0,5 \%$ alatt

\begin{tabular}{|c|c|c|c|c|c|c|c|c|c|c|c|c|c|c|c|c|}
\hline \multirow{3}{*}{ Típlélésk tax on } & \multicolumn{8}{|c|}{$\begin{array}{l}\text { Borank a-me ellé ki Tujuvédelmi Kö rzet } \\
\text { 1997-2000 }\end{array}$} & \multicolumn{8}{|c|}{$\begin{array}{l}\text { Lank áci e rubả (Gyékényes ) } \\
\text { 2000-2001 }\end{array}$} \\
\hline & & & & \multicolumn{2}{|l|}{$\delta_{\mathrm{sz}}$} & & & \multicolumn{2}{|l|}{ Nyár } & \multicolumn{2}{|l|}{$\delta_{\mathrm{sz}}$} \\
\hline & & $\mathrm{B} \%$ & $\mathrm{~B} \%$ & $\mathrm{~B} \%$ & $\mathbf{E} \%$ & $\mathrm{~B} \%$ & $\mathrm{E} \%$ & $\mathbf{8} \%$ & E\% & $\mathrm{B} \%$ & $\mathrm{~F} \%$ & $\mathrm{~B} \%$ & $\mathrm{E} \%$ & B\% & E\% & $\mathrm{B} \%$ \\
\hline 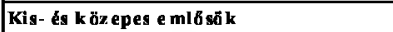 & 47 & 64,4 & 36,4 & 71,0 & 26,1 & 46,1 & 36,4 & 61,4 & 43,0 & 69,3 & 30,9 & 66,7 & 26,1 & 56,4 & 35,0 & 62,6 \\
\hline Irdei cicḱny (Sorex a raneus & & & 0,9 & 1,0 & 0,6 & 0,2 & 0,2 & 0,1 & 0,7 & 0,3 & & & & 0,9 & & \\
\hline Mezei cickány (Crocidura leacodon) & & & & & & & & & 0,7 & 2,8 & 1,1 & 1,5 & & & & \\
\hline Cick kny (Soricidae spp.) & 0,7 & 0,4 & 0,6 & 1.5 & & & 0.4 & 0,2 & 1,3 & 1,9 & & & 1,0 & 2,4 & 2,0 & 1,4 \\
\hline 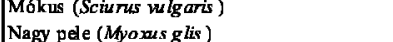 & & & & & 0,3 & 0,8 & $\begin{array}{l}0,2 \\
0,4\end{array}$ & $\begin{array}{l}0,3 \\
0,6\end{array}$ & 0,7 & 0,2 & & & & & & \\
\hline ipodemus sylvaticus ) & 10 & 14,4 & 6,1 & 4,7 & 3,5 & 6,2 & 6,0 & 9,9 & 4,7 & 6,3 & 1,1 & 1,3 & 0.7 & 0,8 & 5,4 & 7,0 \\
\hline Sárganty akh erdei oger (Apodem us flavio & 5,2 & 6,1 & 3,2 & 5,2 & 3,5 & 4,4 & 4,4 & 6,2 & 4,0 & 8,1 & & & 1,0 & 1,7 & 2,0 & 3,4 \\
\hline Pirók erdeiegó (Apodemus o & 0,2 & 0,3 & 0,8 & 0,9 & 0,3 & 0,2 & 0,2 & 0,2 & 0,7 & 1,3 & & & & & 2,0 & 7,1 \\
\hline Erdeiegr (Apo de & 3,5 & 2,6 & 2,3 & 3,1 & 1,7 & 2,1 & 3,2 & 3,4 & & & & & 0,4 & 0,5 & & \\
\hline Vande & 0,4 & 0,4 & 0,4 & 1,8 & & & 0,4 & 0,3 & & & & & & & & \\
\hline Törpecgér (Micromys minutu & 0,9 & 0,8 & 0,2 & + & & & 0,2 & 0,2 & & & 1,1 & 1,3 & & & 0,7 & 2,4 \\
\hline Pézsmap ocok (Ondatra zibethicus) & & & 0,2 & 0,9 & 0,1 & 0,1 & & & & & & & & & & \\
\hline Vkipocok (A ricoila terrestris) & 0,2 & 1,1 & & & 0,1 & 0,6 & & & 0,7 & 0,9 & 3,2 & 11,3 & & & & \\
\hline Erdei pocok (Clethrion an & 23, & 35,5 & 20,5 & 51,1 & 14,3 & 28,9 & 18,3 & 38,7 & 16,7 & 25,2 & 9,6 & 23,5 & 8,4 & 23,6 & 10,1 & 20,4 \\
\hline Mezei pocok $(M$ & 1,4 & 2,7 & 0,4 & 0,7 & 0,4 & 1,7 & 0,2 & 0,2 & 12,1 & 20,7 & 11,6 & 17,0 & 12,6 & 26,4 & 12,1 & 20,4 \\
\hline Csali & & & & & & & & & & & 3,2 & 10,8 & 0,4 & + & & \\
\hline Pocok (Microtus spp.) & & & 0,4 & + & 0,1 & 0,1 & 0,5 & 0,7 & & & & & 0,4 & 0,1 & & \\
\hline Rágcsáló (Rodentia & 0,4 & + & & & 0,7 & 0,4 & 1,4 & 0,1 & & & & & 0,7 & + & & \\
\hline Mezeiny & & & 0,2 & 0,2 & 0,4 & 0,5 & 0,2 & 0,3 & 0,7 & 1,5 & & & & & 0,7 & 0,5 \\
\hline & & & & & & & & & & & - & & & - & & \\
\hline Menj & & & 0,4 & & 0,1 & 0,1 & & & & & & & & & & \\
\hline Csälkö̈s vada k & 17 & 21,6 & 11,0 & 12,5 & $\mathbf{3 , 5}$ & 4,1 & 3,3 & 1,8 & 14,1 & 12,2 & 9,6 & 15,6 & $\mathbf{3 , 5}$ & 5,8 & 2,7 & 2,7 \\
\hline Vaddi & 6,7 & 17,0 & 3,8 & 10,0 & 0,6 & 2,0 & 0,5 & 0,2 & 4,7 & 9,2 & 1,1 & 10,4 & 1,1 & 2,0 & 2,7 & 2,7 \\
\hline$\delta z_{z}(C$ & 4,5 & 1,9 & 1,9 & 0,3 & 19 & 1,7 & 1,2 & 0,4 & 2,7 & 0,6 & 1,1 & 0,6 & 0,4 & 0,9 & & \\
\hline us ) & 5,9 & 2,4 & 3,4 & 1,4 & 0,8 & 0,2 & 1,6 & $\begin{array}{l}1,2 \\
1,2\end{array}$ & 4,0 & 1,3 & $\begin{array}{l}2,1 \\
2,1\end{array}$ & 0,2 & $\begin{array}{l}3_{3}, 3 \\
1,3\end{array}$ & 2,5 & & \\
\hline Starva & 0,5 & 0,3 & 1,9 & 0,8 & 0,8 & 0,2 & & & 2,7 & 1,1 & 5,3 & 4,4 & 0,7 & 0,4 & & \\
\hline Hazi & 0,4 & 0,9 & , & (3) & 0,2 & $\mathbf{a , 1}$ & . & - & - & - & 1,1 & 3,7 & 0,4 & 2,8 & $\cdot$ & - \\
\hline $\mathbf{K u}$ & 0,2 & 0,6 & & & 0,1 & + & & & & & 1,1 & 3,7 & & & & \\
\hline Házi maxska ( $F$ & 0,2 & 0,3 & & & 0,1 & 0,1 & & & & & & & 0,4 & 2,8 & & \\
\hline ladarak & $\begin{array}{l}7,2 \\
7,7\end{array}$ & 7,8 & 8,3 & 10,8 & $8, \mathbf{3}$ & $\begin{array}{l}0,1 \\
11,4\end{array}$ & $2, \mathbf{8}$ & 2,0 & 4,7 & 3,7 & 6,4 & 10,8 & $\mathbf{3 , 2}$ & 2,5 & 2,0 & 0,1 \\
\hline & & & 0,2 & & & & & & & & & & & & & \\
\hline Csuszka ( & 0,2 & & & & & & & & & & & & & & & \\
\hline Kistestú & 0 & 4,9 & 5,6 & 3,1 & 6,4 & 4,9 & 1,9 & 0,9 & 2,7 & 1,2 & 2,1 & 0.4 & 2,4 & 0,9 & 2,0 & 0,1 \\
\hline Fácán (Phasian us œolchicu & 0,9 & 1,2 & 1,1 & 6,2 & 0,8 & 4,4 & 0,5 & 0.9 & 2,0 & 2,5 & 1,1 & 4,0 & & & & \\
\hline
\end{tabular}


15. melléklet: folytatása

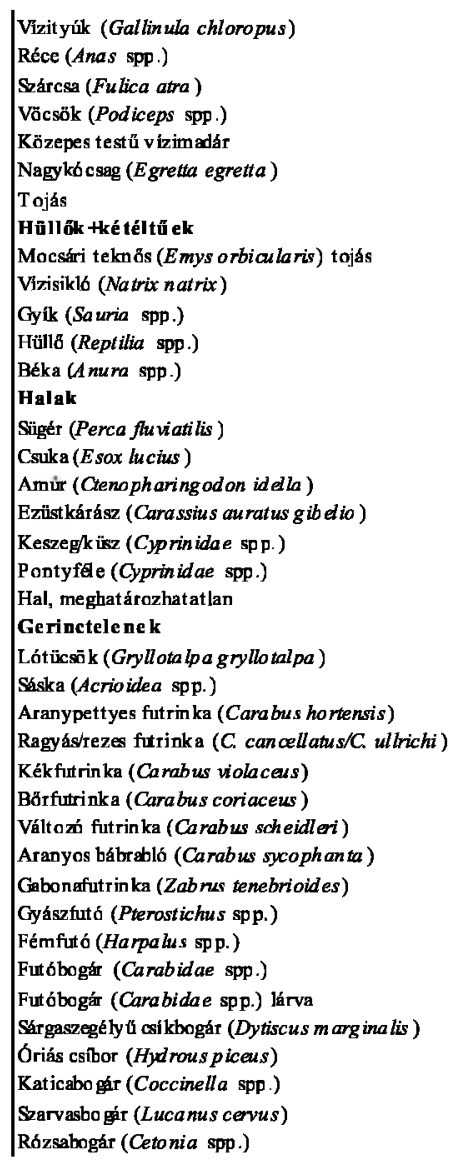

\begin{tabular}{|c|c|c|c|c|c|c|c|c|}
\hline \multirow{3}{*}{0,4} & \multirow{3}{*}{0,8} & 0,2 & + & & & \multirow[b]{3}{*}{0,2} & \multirow[b]{3}{*}{0,1} & \\
\hline & & & & 0,1 & 0,2 & & & \\
\hline & & & & & & & & \\
\hline & & 0,2 & + & 0,3 & 1,6 & & & \\
\hline \multirow[t]{3}{*}{0,5} & 0,9 & 0,2 & 1,5 & 0,3 & 0,3 & & & \\
\hline & & 0,2 & + & & & & & \\
\hline & & 0,6 & + & 0,4 & + & 0,2 & 0,1 & \\
\hline \multirow[t]{2}{*}{0,4} & + & 2,1 & 1,7 & 1,8 & 0,4 & - & - & 7,4 \\
\hline & & 0,2 & 0,2 & 0,3 & 0,1 & & & \\
\hline \multirow[t]{4}{*}{0,4} & + & & & 0,4 & + & & & 0,7 \\
\hline & & 0,2 & + & 0,1 & + & & & \\
\hline & & 1,3 & + & 0,6 & + & & & \\
\hline & & 0,4 & 1,5 & 0,4 & 0,2 & & & 6,7 \\
\hline 1,8 & 0,6 & 2,1 & $\mathbf{0 , 1}$ & $\mathbf{0 , 4}$ & 0,9 & 1,8 & 0,4 & - \\
\hline \multirow[t]{3}{*}{0,4} & + & & & & & 0,2 & 0,2 & \\
\hline & & 0,2 & + & & & 0,2 & + & \\
\hline & & 0,2 & + & 0,1 & 0,5 & & & \\
\hline \multirow[t]{3}{*}{0,4} & 0,3 & 0,4 & + & & & 0,4 & 0,1 & \\
\hline & & & & & & 0,2 & + & \\
\hline & & 0,2 & + & 0,1 & + & 0,4 & + & \\
\hline 1,0 & 0,3 & 1,1 & 0,1 & 0,2 & 0,4 & 0,4 & 0,1 & \\
\hline \multirow[t]{2}{*}{7,4} & 0,4 & 27,1 & 0,3 & 31,6 & 2,0 & 22,5 & 1,2 & 8,1 \\
\hline & & & & 0,6 & + & & & \\
\hline \multirow[t]{2}{*}{1,3} & 0,1 & 9,0 & 0,1 & 6,7 & 0,7 & 8,2 & 0,6 & 0,7 \\
\hline & & 1,1 & + & 0,3 & + & 0,2 & + & \\
\hline \multirow[t]{3}{*}{0,5} & + & 3,4 & + & 4,6 & 0,4 & 1,1 & + & \\
\hline & & 1,7 & + & 5,9 & 0,4 & 3,3 & 0,1 & \\
\hline & & 0,2 & + & 0,1 & + & 0,2 & + & \\
\hline \multirow[t]{2}{*}{0,5} & + & 1,3 & + & 3,1 & 0,1 & 0,7 & + & 0,7 \\
\hline & & & & & & 0,2 & + & \\
\hline 0,5 & + & 1,3 & + & 3,4 & 0,1 & 2,6 & 0,1 & 2,0 \\
\hline 0,2 & + & & & & & & & \\
\hline 1,3 & 0,2 & & & 0,3 & + & 1,6 & 0,1 & \\
\hline \multirow[t]{4}{*}{0,9} & + & & & 0,1 & + & & & \\
\hline & & & & 0,1 & + & & & \\
\hline & & & & 0,7 & + & & & \\
\hline & & 1,7 & + & 1,7 & + & 0,5 & + & \\
\hline
\end{tabular}




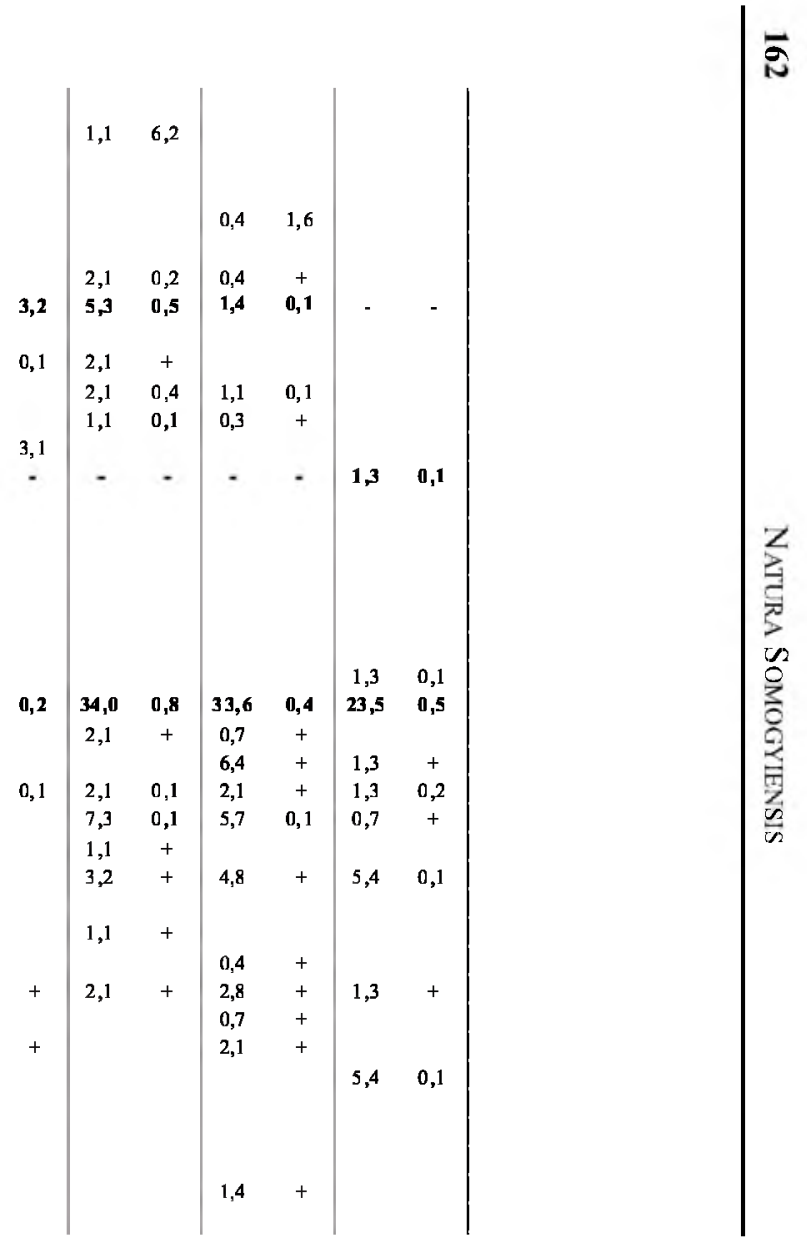




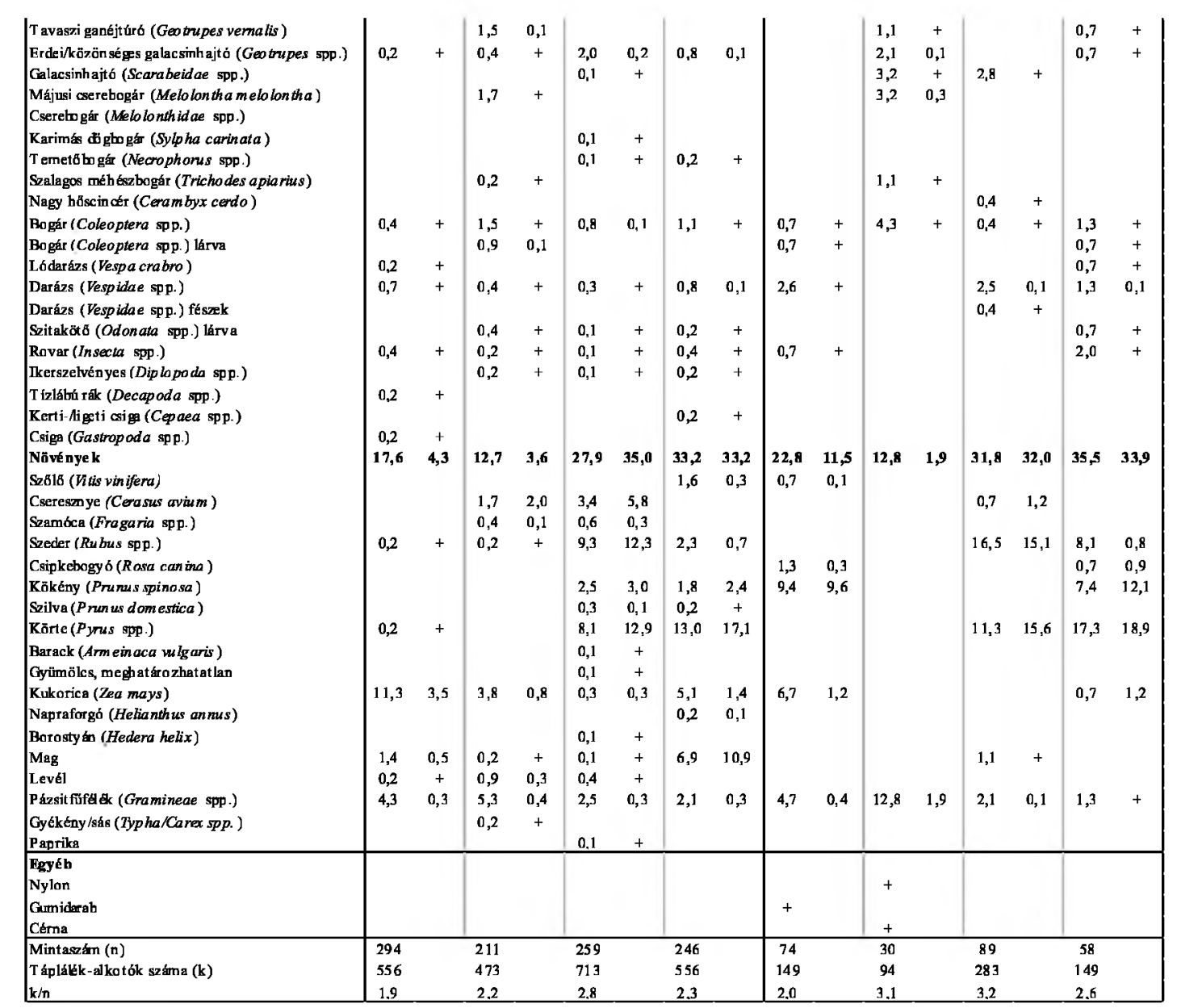


16. melléklet: Az aranysakál évszakonkénti táplálék-összetétele a faj hazai elterjedésének peremén és központjában

Jelmagyarázat: E\% =relatív elófordulási gyakoriság, \%; $\%$ \% = biomassza számítás szerinti összetétel, \%; $+=$ előfordulás $0,5 \%$ alatt

\begin{tabular}{|c|c|c|c|c|c|c|c|c|c|c|}
\hline \multirow{3}{*}{ Táplálék taxon } & \multirow{2}{*}{\multicolumn{2}{|c|}{\begin{tabular}{|l} 
Hazai el terj edés \\
peremén \\
(Mike-Csäköly)
\end{tabular}}} & \multicolumn{8}{|c|}{$\begin{array}{l}\text { Hazai eltøjedés központjấban } \\
\text { (Kétüf falu körzete) } \\
\text { Z000-2001 }\end{array}$} \\
\hline & & & \multicolumn{2}{|l|}{ TE I } & \multicolumn{2}{|c|}{ Tavasz } & \multicolumn{2}{|l|}{ Nyár } & \multicolumn{2}{|l|}{$\tilde{\text { Ósz }}$} \\
\hline & $\% \mathrm{E}$ & $\% \mathbf{B}$ & $\% \mathrm{E}$ & $\% \mathrm{~B}$ & $\% \mathrm{E}$ & $\% \mathrm{~B}$ & $\% \mathrm{E}$ & $\% \mathrm{~B}$ & $\% \mathrm{E}$ & $\% \mathrm{~B}$ \\
\hline Kis- és söz epes e mlásōk & 45,1 & 55,6 & 89,4 & 96,8 & 58,1 & 87,3 & 47,0 & 82,8 & 80,1 & 94,7 \\
\hline Vak ond (Talpa europaea) & & & & & 0,5 & 0,1 & & & & \\
\hline Cickány (Soricidae spp.) & & & & & 0,5 & 0,1 & & & & \\
\hline Mogyorós pele (Muscardinus a vellanarius) & & & 0,4 & 0,5 & & & & & & \\
\hline Kö ̄̈nséges erdeiegér (A po dem us sylva ticus) & & & 10,2 & 10,0 & 4,0 & 6,7 & 1,9 & 2,0 & 2,2 & 1,8 \\
\hline Sárgan yakú erdeiegór (Apodem us flavicoll is) & & & 4,6 & 5,8 & 4,5 & 5,4 & 0,4 & 0,8 & 1,5 & 3,2 \\
\hline Pirók egér (Apodem us agrarius) & & & 2,8 & 2,6 & & & 0,4 & 0,5 & 0,5 & 0,2 \\
\hline Erdeiegér (Apodem us sp p.) & 7,8 & 5,4 & 2,1 & 1,6 & 1,5 & 0,3 & 2,3 & 2,4 & 0,7 & 0,6 \\
\hline Törpeegér (Microtus m in utus) & & & 4,9 & 3,1 & 1,5 & 0,6 & 0,7 & 0,1 & 2,9 & 1,1 \\
\hline Vixipocok (Avvicola terrestris) & & & & & 1,0 & 3,3 & 0,4 & 0,2 & & \\
\hline Erdei pocok (Clethrionomys gla reolus) & 3,9 & 6,2 & 13,1 & 15,3 & 5,1 & 5,9 & 5,6 & 7,2 & 2,0 & 2,6 \\
\hline Földi pocok (Microtus subteraneus) & & & 0,4 & 0,4 & & & & & & \\
\hline Mezei pocok (Microtus a rualis) & 29,4 & 39,1 & 48,8 & 55,5 & 37,5 & 59,1 & 31,6 & 64,6 & 68,6 & 82,7 \\
\hline Csalitjáró pocok (Microtus a grestis) & & & 2,1 & 2,0 & 2,0 & 5,8 & 3,4 & 5,0 & 1,0 & 0,6 \\
\hline Pocok (Microlus spp.) & 2,0 & 4,6 & & & & & & & & \\
\hline Mezei nyúl (Lepus europaeus) & 2,0 & 0,3 & & & & & 0,4 & + & 0,7 & 1,9 \\
\hline Raga do zók & 2,0 & + & - & - & - & - & - & - & - & - \\
\hline Nyest (Martesfoina) & 2,0 & + & & & & & & & & \\
\hline Csülkŏs vad & 23,5 & 41,0 & 0,7 & 2,5 & 5,1 & $\mathbf{5 , 5}$ & 2,2 & $\mathbf{3 , 5}$ & 2,5 & 2,7 \\
\hline Vaddisznó (Sus scrofa) & 7,8 & 33,9 & 0,4 & 2,5 & 0,5 & + & & & 0,7 & 2,6 \\
\hline Vaddisznó (Sus scrofa) juv. & & & & & 0,5 & 0,5 & & & & \\
\hline Ó (Capreolus capreolus) & 2,0 & 1,2 & & & 3,1 & 1,0 & 0,7 & 0,3 & 0,7 & + \\
\hline Gimszarvas (Cervus elaphus) & 7,8 & 4,9 & 0,3 & + & 1,0 & 3,9 & 0,4 & 0,1 & 0,7 & + \\
\hline Ğ̈mszarvas (Cervus elaphus) juv. & & & & & & & 1,1 & 3,1 & 0,3 & 0,1 \\
\hline Dámvad (Cervus dama) & 3,9 & 0,5 & & & & & & & & \\
\hline Szarvasféle (Cervidae spp.) & 2,0 & 0,5 & & & & & & & & \\
\hline Háziálla tok & - & - & - & - & $\mathbf{0 , 5}$ & + & 1,9 & $\mathbf{9 , 8}$ & $\mathbf{0 , 7}$ & 0,5 \\
\hline Házi macsk a (F elis catus) & & & & & 0,5 & + & 0,7 & 0,4 & & \\
\hline Kecske/szarvasmarha & & & & & & & & & 0,7 & 0,5 \\
\hline Sertes & & & & & & & 1,9 & 9,4 & & \\
\hline Madarak & 2,0 & 2,1 & 1,4 & 0,5 & 4,5 & 4,3 & 3,4 & 0,4 & 1,2 & 0,1 \\
\hline Cinege (Panss spp.) & & & & & & & & & 0,2 & + \\
\hline Kistestú ének esmadár (Passeriformes spp.) & 2,0 & 2,1 & & & 2,0 & 0,3 & 0,7 & 0,1 & 1,0 & 0,1 \\
\hline Fácán (Pha sianus colchicus) & & & 1,4 & 0,5 & 2,5 & 4,0 & 0,4 & 0,2 & & \\
\hline Könpes testli madár & & & & & & & 0,4 & + & & \\
\hline Tojás & & & & & & & 1,9 & 0,1 & & \\
\hline Hũllb k+kétélttuek & 5,9 & 0,5 & - & - & 2,0 & 1,8 & 0,4 & + & - & - \\
\hline Vizi sikló (Natrix naträx) & & & & & 0,5 & 0,6 & & & & \\
\hline Sikló (Colubridae spp.) & & & & & 1,0 & 1,2 & & & & \\
\hline Gyík (Sauria spp.) & 5,9 & 0,5 & & & 0,5 & + & 0,4 & + & & \\
\hline Halak & - & - & 0,4 & + & 0,5 & + & - & - & - & - \\
\hline Csuka (Esox lucius) & & & 0,4 & + & & & & & & \\
\hline Hal, meghatározhatatlan & & & & & 0,5 & + & & & & \\
\hline
\end{tabular}


16. melléklet: folytatása

\begin{tabular}{|c|c|c|c|c|c|c|c|c|c|c|}
\hline Gerincte lene k & 15,7 & 0,4 & 0,7 & + & 18,7 & 0,3 & 23,5 & $\mathbf{0 , 2}$ & 2,5 & + \\
\hline Lótücsōo k (Gryllotalpa gryllo ta lpa) & 3,9 & 0,1 & & & 0,5 & + & 0,7 & + & & \\
\hline Sáska (Acrio id en spp.) & & & & & & & 3,4 & + & 0,2 & + \\
\hline Imádkozó sáska (Mantis religiosa) & & & & & & & 0,7 & + & 1,1 & + \\
\hline Arany pettyes futrinka (Carabus hortensis) & 3,9 & 0,1 & & & 3,5 & + & 2,6 & + & & \\
\hline Ragyás-/rezes fut rinka (Carabus cancell atu s/u lluichi) & & & & & 3,5 & 0,1 & 2,2 & + & 0,2 & + \\
\hline Kékfutrin ka (Carabus violaceus) & 3,9 & 0,2 & & & & & & & & \\
\hline Börffutrink a (Carabus coriaceus) & & & & & 1,5 & + & 1,5 & + & & \\
\hline Gyászfutó (Pterostichus spp.) & & & & & 0,5 & + & 2,6 & + & & \\
\hline Fánfutó (Harpalus spp.) & & & & & & & 0,4 & + & & \\
\hline Futóbogár (Carabidae spp.) & 2,0 & + & 0,4 & + & 0,5 & + & 1,9 & + & 0,6 & + \\
\hline Erdei/közönséges glacsin hajtó (Geotrupes spp.) & & & & & 0,5 & + & & & & \\
\hline Galacsin hajtó (Scarabeidae spp.) & & & & & & & 0,4 & + & & \\
\hline Maj usi cserebogár (Melo lo nth a melolontha) & & & & & 5,7 & $\mathbf{0 , 1}$ & 1,1 & 0,1 & & \\
\hline Cserebogár (Melolonthidae spp.) & & & & & 1,0 & + & & & & \\
\hline Szal agos mêtéstho gar (Trichodes apiarius) & & & & & & & 0,7 & + & & \\
\hline Bogár (Coleoptera spp.) lárva & & & & & 0,5 & + & & & & \\
\hline Bogár (Coleoptera spp.) & & & & & 0,5 & + & 0,4 & + & 0,2 & + \\
\hline Bodobács (Lygaeidae sp p.) & & & & & & & & & 0,2 & + \\
\hline Poszméh (Bombus spp.) & & & & & & & 0,4 & + & & \\
\hline Fran ciadirázs (Po lisstes gallicus) & & & & & & & 0,4 & + & & \\
\hline Daráz (Vexpidae spp.) & & & 0,3 & + & & & 3,0 & + & & \\
\hline Rovar (In secta spp.) & 2,0 & + & & & & & & & & \\
\hline Ikerszelvényes (Diplopoda spp.) & & & & & 0,5 & + & 0,4 & + & & \\
\hline Csiga (Gastropoda sp p.) & & & & & & & 0,7 & + & & \\
\hline Nö vé ny ek & 5,9 & 0,4 & 7,4 & $\mathbf{0 , 2}$ & 10,6 & 0,8 & 21,6 & 3,3 & 13,0 & 2,0 \\
\hline Cseresznye (Cerasus avium) & & & & & 1,0 & 0,2 & 0,7 & 0,1 & & \\
\hline Szeder (Rubus spp.) & & & & & & & 6,7 & 0,8 & 0,2 & + \\
\hline Csipkebogyó (Rosa canina) & & & & & & & & & 0,2 & 0,1 \\
\hline Szilv a (Prunus do mestica) & & & & & & & 0,4 & 0,1 & & \\
\hline Käkény (Prunus spinosa) & & & 0,7 & + & & & & & 5,5 & 1,2 \\
\hline Körte (Pynus spp.) & & & & & & & 2,6 & 0,8 & 1,5 & 0,4 \\
\hline Gy ümölcs, meghatározhat atlan & & & & & & & & & & \\
\hline Kuko rica (Zea mays) & 3,9 & 0,3 & & & 0,5 & + & 1,9 & 0,8 & 3,4 & 0,2 \\
\hline Napraforgo (Helianthus annus) & & & & & 0,5 & 0,3 & & & 0,2 & + \\
\hline Mag & & & 0,4 & + & 1,0 & 0,1 & 1,1 & + & & \\
\hline Levá & & & & & & & & & & \\
\hline Pázsitfúfélék (Gramineae spp.) & 2,0 & 0,1 & 6,3 & 0,2 & 7,6 & 0,2 & 8,2 & 0.7 & 2,0 & + \\
\hline Mintaszám (n) & 24 & & 75 & & 59 & & 78 & & 121 & \\
\hline Táplálák-alko tók száma (k) & 51 & & 283 & & 198 & & 268 & & 408 & \\
\hline $\mathrm{k} / \mathrm{n}$ & 2,1 & & 3,8 & & 3,4 & & 3,4 & & 3,4 & \\
\hline
\end{tabular}




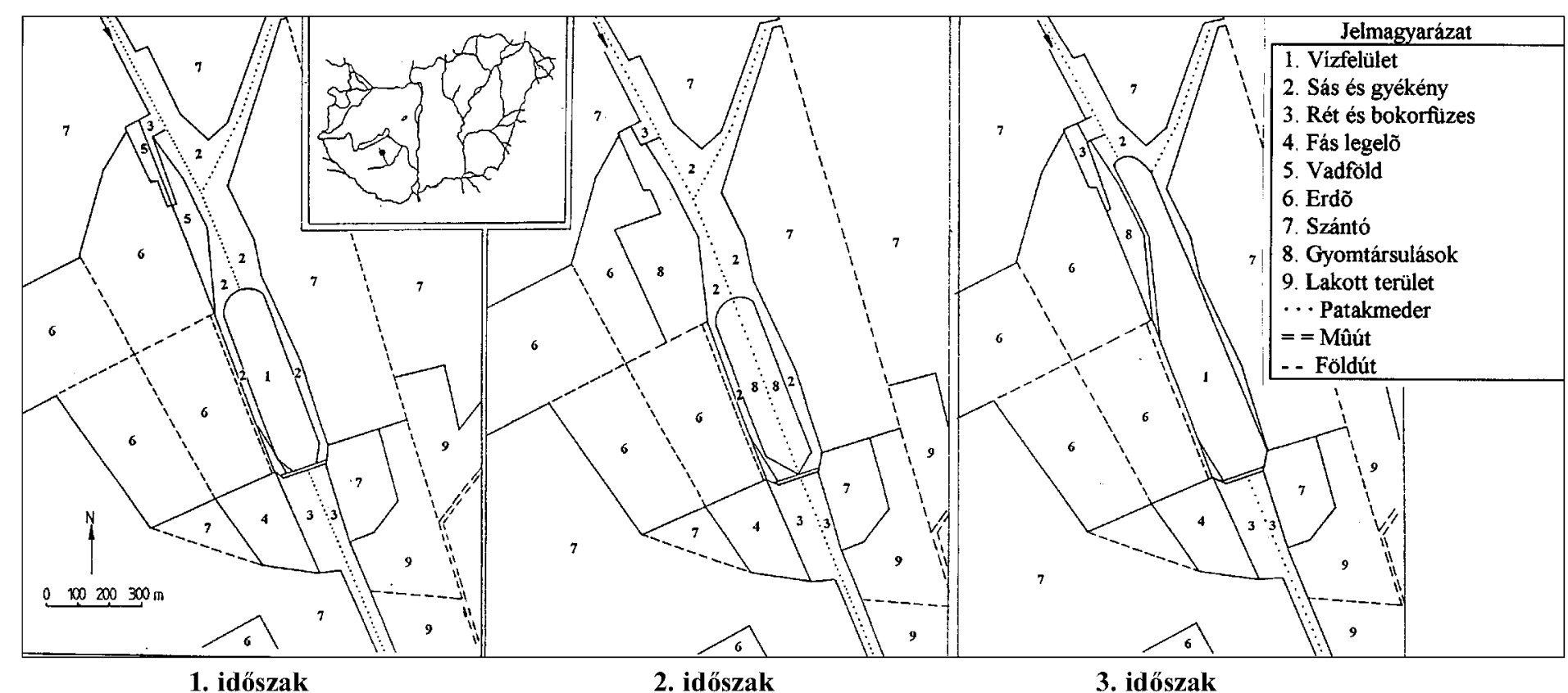

84. ábra: A Fonói halastó körzetének változása a vizsgált időszakban 


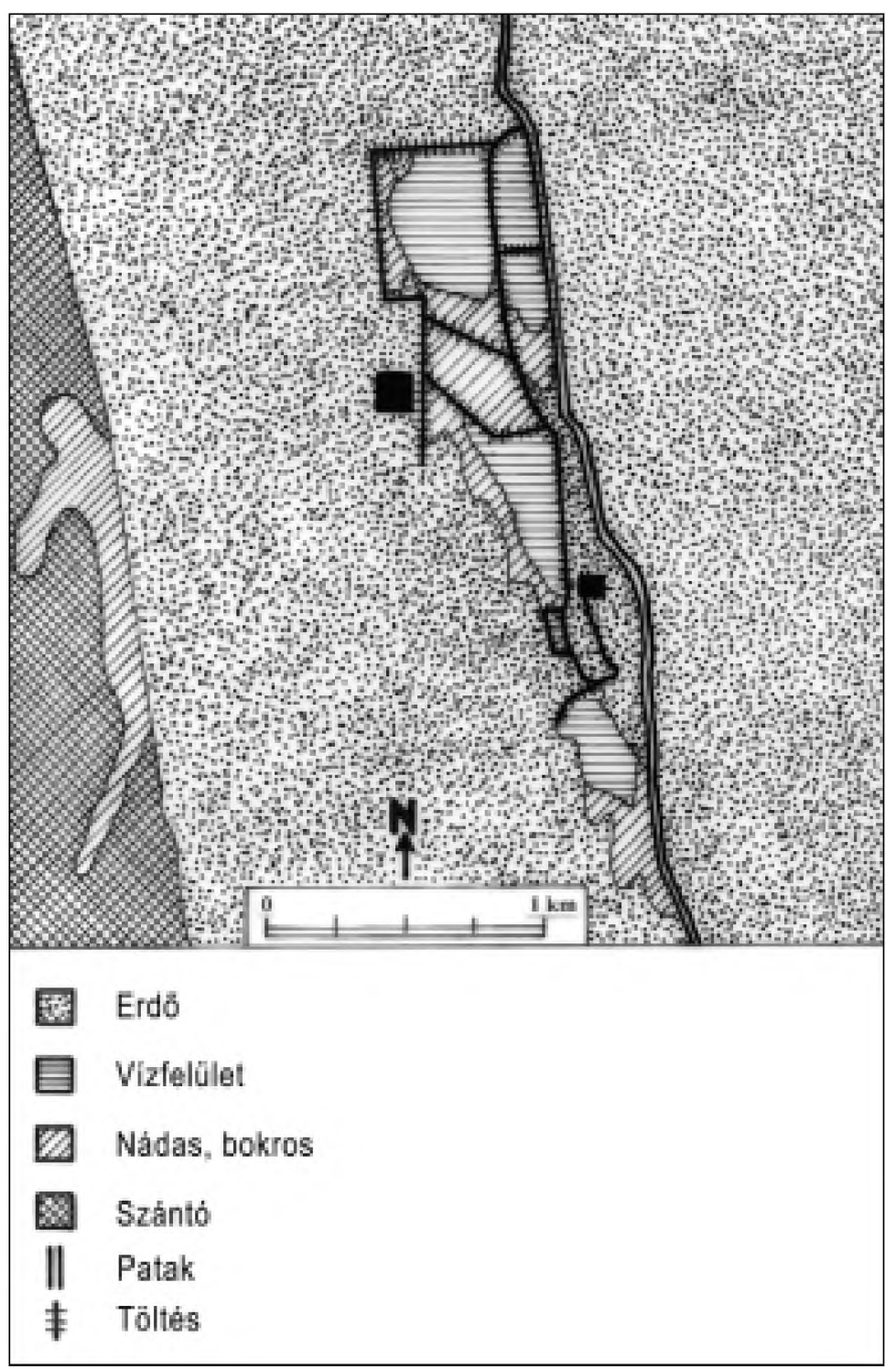

85. ábra: A Boronka-melléki tájvédelmi körzetben vizsgált terület (Dávodi halastavak)

Megjegyzés: A fekete négyzetek jelölik a kisemlős csapda kvadrátokat helyeit 


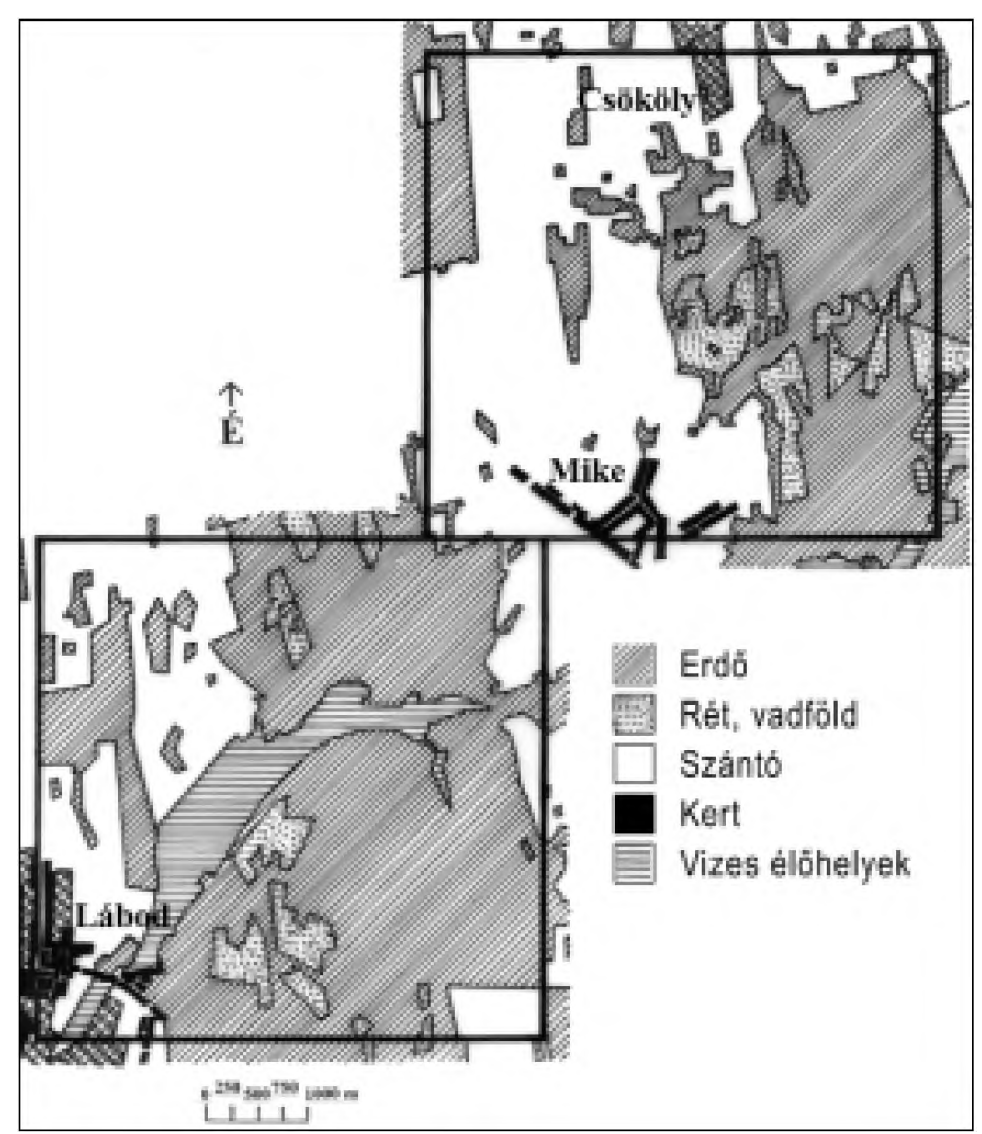

86. ábra: Az aranysakál hazai elterjedésének peremén vizsgált terület (Lábod-Mike-Csököly) 


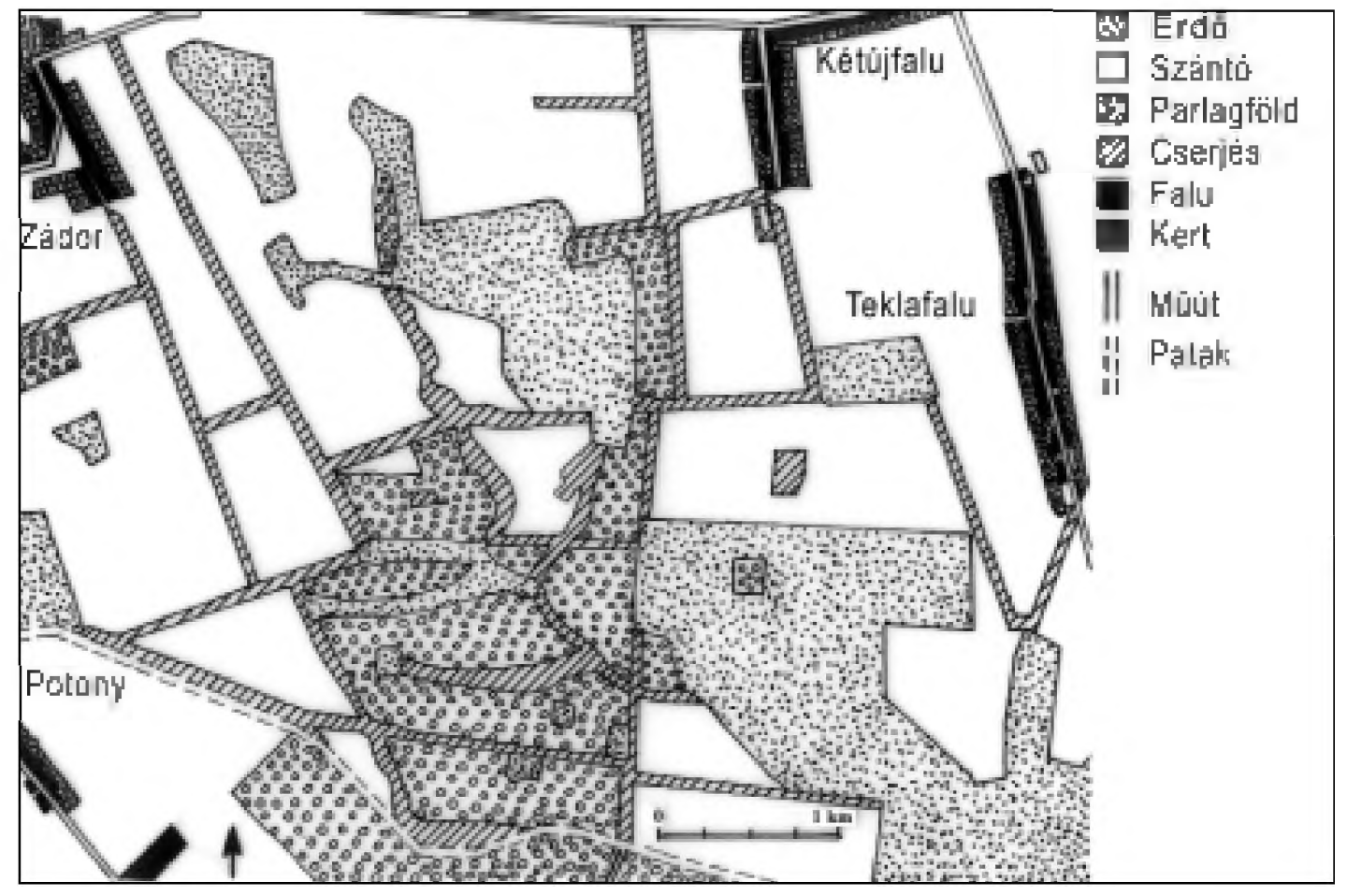

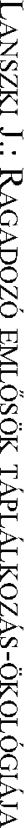

87. ábra: Az aranysakál hazai elterjedési központjáhan vizsgált terület 


\section{Feeding ecology of mammal predators living in Hungary}

The present study features seven carnivores examined between 1991 and 2001 namely, otter (Lutra lutra), stoat (Mustela erminea), stone marten (Martes foina), pine marten (Martes martes), badger (Meles meles), red fox (Vulpes vulpes) and golden jackal (Canis aureus). The areas studied are in the South-western part of Hungary; contain cultivated agricultural lands (the region of Fonó Fishpond, Mike-Csököly and Kétújfalu), forest (Lankóci Forest at Gyékényes), or forest surrounding pond systems (Boronka Nature Landscape Area and Petesmalom). The feeding habits of otters was also examined at the aquatic habitats of the Danube-Drava National Park, namely at the Drava River (ÖrtilosSzentmihályhegy and Vízvár), at backwaters (Bélavár, Babócsa, Kisbók), at lakes (the quarry lakes of Somogyudvarhely) at abandoned fishponds (Barcs-Rigóc/Barcs Juniper Woodland Nature Landscape Area), at canals (Korcsina and Dombó) and stream (Rinya at Babocsa). To study the feeding habits of carnivores was accomplished by analysis of excrements, using more than 10,000 samples.

The feeding behaviour of otters and their fish preference was examined at eutrophic fishponds (Fonó Fishpond and Boronka Nature Conservation Area). The correlations coefficients between the otters' fish diet and the available fish stock were generally close. For example at the Fonó Fishpond during a 6 year period, the values received were 0.56 $(\mathrm{P}<0.05), 0.87(\mathrm{P}<0.001), 0.93(\mathrm{P}<0.001), 0.79(\mathrm{P}<0.05), 0.36(\mathrm{NS})$, and $0.81(\mathrm{P}<0.001)$, while during a 2 year period at the Boronka Nature Conservation Area they were 0.02 (NS) and 0.33 (NS), respectively. The occasionally low correlation coefficients indicated that the otters' fish prey selection was determined not only by the availability of species, but also by its size $\left(\mathrm{r}_{\mathrm{S}}=0.70, \mathrm{P}<0.01\right)$. The fish preference calculations were performed with Ivlev's index of preference $\left(\mathrm{E}_{\mathrm{i}}\right.$, min.:-1, max.: +1$)$. Regardless of species, the otters avoided $\left(E_{j}=-0.51\right)$ fish heavier than $1000 \mathrm{~g}$, with a preference for individuals weighing between 500 and $1000 \mathrm{~g}\left(\mathrm{E}_{\mathrm{i}}=0.79\right)$. No substantial or clear preference was observed in the weight range below $500 \mathrm{~g}\left(\mathrm{E}_{\mathrm{i}}=-0.02-0.38\right)$. The preference for fish in accordance with their characteristic sites of occurrence within the body of water was also significant $(\mathrm{P}<0.01)$. They avoided fish living primarily in open water $\left(\mathrm{E}_{\mathrm{i}}=-0.64\right)$ and to a lesser degree those occurring near the pond bed $\left(E_{j}=-0.22\right)$. They favoured fish inhabiting the area with a covering of aquatic plants $\left(\mathrm{E}_{\mathrm{i}}=0.46\right)$ and showed a preference to a lesser degree for fish living in the shallow littoral regions $\left(E_{i}=0.14\right)$. With the cessation of fish farming and the effect of the drastic changes which occurred in the vegetation, the otters fed substantially on the stock of alternative sources of prey such as amphibians and water insects as well as terrestrial animals, and at such time, depending on season, fish became a secondary source of prey. In the aquatic habitats, such as the DravaDistrict region, like the Drava River, the Barcs Juniper Woodland Nature Landscape Area, the quarry lakes, the backwaters of Bélavár, Kisbók and Babócsa the primary source of prey consisted of fish, provided there was an abundant fish stock.. The occa- 
sionally low frequency of occurrence (less than 50-60\%) of fish in the diet indicated that the amount of available fish stock was less than adequate or varied greatly from season to season. In these habitats the secondary source of prey (birds, amphibians and reptiles) played an important role. In wetland habitats that partly dry out during the summer, such as the Lankóci Forest or certain canals and streams, the importance of small mammals and water insects also increased, while the significance of fish in the diet was reduced. The diet of the otters living in the area of the Tetves Stream (which can be considered a special case) contained an extremely large proportion (62\%) of crayfish during the summer. Due to the greater amount of fish consumption the trophic niche of otters living in ponds was narrower than that of the ones near the Drava's aquatic habitats. The correlation between the frequency of occurrence and the biomass data of the otters' diet was analysed using samples collected at the Ponds of Petesmalom, the Lankóci Forest, and the Tetves Stream. Data according to the various taxa showed significant $(\mathrm{P}<0.001)$ Pearson correlation coefficients of 0.92 (mammals), 0.80 (birds), 0.93 (reptiles and amphibians), 0.90 (fish), 0.88 (invertebrates) and $-0.78, \mathrm{P}=0.066$ (plants). The data indicates that frequency of occurrence of prey taxa quantify the consumed biomass with high reliability.

The most important elements of the stoat's diet consisted of small mammals, mainly voles. The proportion of small mammals in the stoat's diet was the highest during the winter and decreased continuously towards the summer and the autumn. At the same time the importance of birds and insects increased but reptile and plant consumption could also be detected. In habitats, which differed significantly compared to some of the others, like the Fonó Fishpond region (agricultural landscape) and the Lankóci Forest, in spite of the monotony of the stoats' diet their trophic niche was wide according to the main taxa. The number of prey and plant taxa at these habitats studied was 18 or 11 , and 4 or 1, respectively. Body weight of the stoats' major prey varied between 15-50 gramms. The majority of prey species was terrestrial but the proportion of arboreal prey was also substantial and aquatic species occurred in the diet as well.

The diet composition of the stone marten was analysed in agricultural landscape (around the Fonó Fishpond) and in a village (at the inner area of Fonó). Individuals of the different habitats often utilised the same source of diet and the size of their niche overlap was $78 \%$. The primarily important food taxa were plants, mainly fruits in the diet at both habitats (based on the annual mean of 34\% and $31 \%$ frequency of occurrence, respectively). Besides plants the most important prey taxa consisted of small mammals $(20 \%)$ in the agricultural area, and of birds $(20 \%)$ in the village. There was a substantial difference in the consumption of domesticated (mainly poultry) species ( $4 \%$ vs. $15 \%$ ). The fact that stone martens in the agricultural area more frequently consumed terrestrial and wild prey contrary to their "urban" counterparts contributed to their trophic niche segregation. The number of prey and plant taxa of these two areas was 55,35 and 17, 19, respectively. Prey was typically in the $15-50 \mathrm{~g}$ weight category (55, and $47 \%$ in the agricultural landscape and the village, respectively) and lived on ground level ( 81 and $71 \%$, resp.), but martens living in the village hunted more frequently preys above 50 $\mathrm{g}$ (14 and $24 \%$, resp.) and arboreal prey (17 and 29\%, resp.). The diet of the stone martens living in the agricultural area showed high similarity to those of other carnivores of small and medium body size.

The most important items of the pine martens' diet consisted of small mammals both in the Boronka Nature Conservation Area and in the Lankóci Forest. Their proportion was especially high during the winter and spring season. The most important prey spe- 
cies was the bank vole but wood mice also showed high frequency. In the Boronka Nature Conservation Area the pine martens slightly preferred bank vole $\left(\mathrm{E}_{\mathrm{i}}=0.1\right)$ and dormouse $\left(E_{i}=0.16\right)$ as prey, while wood mice $\left(E_{i}=-0.14\right)$ and shrews $\left(E_{i}=-0.28\right)$ were preyed to a lesser degree than their frequency of occurrence in the environment. Birds had secondary importance in the pine martens' diet only during spring and summer. The birds in the pine martens' diet mainly consisted of singing-birds with small body size. Invertebrates frequently occurring in the diet were consumed in small amount. The importance of other diet taxa significantly differed according to the pine martens' habitat. For instance during the winter pine martens consumed substantial amounts of game carcass and fish near fishponds. The importance of plants depended on the season and habitat. Wild fruits could provide the most important element of the pine martens' diet during the summer and played an important role during the autumn as well. The pine martens' diet was characterised by a large number of species and was accompanied by a wide trophic niche in each season. The number of prey and plant taxa of the two areas examined was 62, 49 and 11,8 respectively. The prey mainly consisted of small animals weighing less then 50 gramms. Though the pine martens are excellent tree climbers the majority of their prey species were terrestrial. Arboreal species featured relatively rarely among their prey. The pine martens' diet composition showed high similarity to that of foxes living in the same habitat.

The diet composition of badgers living near fishponds surrounded by forests like the Boronka Nature Conservation Area, and of those in agricultural lands like the area of the Fonó Fishpond differed significantly. The diet composition of badgers living in wooded areas was dominated by invertebrates during the winter, and by amphibians from spring to autumn. Small mammals and other prey taxa did not play an important role. The diet composition of badgers living in agricultural land was dominated by invertebrates (especially earthworms) during the summer, and by plants (especially maize) and small mammals (particularly voles) during the autumn. The diet was greatly varied in species but showed a medium to low trophic niche breadth in both regions. The number of prey and plant taxa of the studied two habitats were 47,25 and 11,6 respectively. In the diet dominated the terrestrial prey weighing less than $15 \mathrm{~g}$ due to the frequent occurrence of invertebrates in it. Badgers differed from other terrestrial carnivores regarding their feeding habits. Their trophic niche was among the narrowest of the species examined, thus they could be regarded as specialists within a given habitat. Badgers utilised different diets in various habitats which indicates their adaptability.

The diet composition of the red fox was varied in species together with a wide trophic niche showing excellent adaptability. The diet of foxes living on agricultural land (like the region of the Fonó Fishpond or Kétújfalu) consisted of 40-42 prey and 10-12 plant taxa, respectively. Foxes of the wood habitat showed more taxa in their diet, 66 prey and 15 plant were observed at the Boronka Nature Conservation Area and 47 prey and 8 plant taxa at the Lankóci Forest. The most important items of the diet was provided by small mammals ( $46-94 \%$ by biomass) depending on the season and characteristics of the area. The main prey species were the common vole a cause of economic loss in agricultural areas, and bank vole in the forests. The weight of the majority of their prey ranged between 15-50 g. In the Boronka Nature Conservation Area the red fox slightly favoured bank vole $\left(E_{i}=0.11\right)$ and avoidedo wood mouse species $\left(E_{i}=-0.14\right)$, which were hunted less than their frequency of occurrence. A considerable trophic niche overlap was observed between the red fox and other medium sized terrestrial carnivores. 
Golden jackals settled back to the south-western part of Hungary during the last decade. Jackals living on the edge of their habitat range, mainly consumed small mammals during the winter and early spring (56\%). Consumption of game carcass also played an important role in their diet (red-, roe- and fallow deer and wild boar - the proportion of them biomass consumed was $46 \%$ altogether), most important was the wild boar. Other taxa like birds, reptiles, amphibians, insects and plants did not play a major role in the diet. Hunting of small game (hare, pheasant) was insignificant. The diet of red foxes living in the same area contained 36\% small mammals and $49 \%$ game carcass (by biomass consumed). The diet composition of the jackal and the red fox did not differ substantially and their trophic niche overlap was high especially according to biomass data $(72 \%)$. Individuals living in the central area of the jackals' habitat range in Hungary primarily consumed small mammals (their proportion of consumed biomass ranged between $83-97 \%$, depending on the season), the main item in their diet was common vole. Based on live trapping of small mammals during the autumn jackals favoured common vole $\left(E_{i}=0.33\right)$, while avoided forest species, such as bank vole $\left(E_{i}=-0.59\right)$ and wood mouse species $\left(E_{i}=-0.77\right)$. Consumption of ungulates (mainly carcasses) was increased at the end of spring and summer but even during this period they could only be regarded of secondary importance in the diet. The trophic niche breadth of the jackal was low regardless of the season due to the high proportion of small mammal consumption, which resulted in a small mammal specialist behaviour. Small mammals also dominated (80-94 \%) in the diet of foxes lived in the same area. The diet composition of the jackals and foxes (coexisting the same habitats) were not significantly different, their trophic niche overlap varied between 76-94\% depending on the season. Regardless of the habitat and season an exceptionally high similarity could be observed between the diet composition and feeding habits of jackals and foxes. However, differences could be detected between jackals living on the edge and in the central area of their habitat range (the same phenomena can be stated concerning the foxes). This indicates that the characteristics of the habitats substantially determine the feeding habits of these carnivores. Both species can adapt well to the circumstances provided by a given habitat, which can lead to a diet characterised either by the consumption of considerable percentage of game carcass or of small mammals. The diet composition of jackals avoiding urban areas differs greatly from that of larger predators, their body size and hunting behaviour is between those of the wolf and the red fox, but closer to the red fox. 